\title{
ECOLOGICAL EFFECTS OF CONTAMINANTS AND REMEDIAL ACTIONS IN BEAR CREEK
}

G. R, Southworth

J. M. Loar

M. G. Ryon

J. G. Smith

A. J. Stewart

J. A. Burris ${ }^{1}$

Environmental Sciences Division Publication No. 3810

$\overline{{ }^{1} C .}$ E. Environmental, Inc, 2571 Executive Center, Tallahassee, FL 32301

Date Published-.-January 1992

Prepared for

Environmental Management Department

Health, Safety, Environment:

and Accountability Division

Oak Ridge Y-12 Plant

Prepared by the

OAK RIDGE NATIONAL LABORATORY

Dak Ridge, Tennessee 37831-6286

managed by

MAR'TIN MARIETTA ENERGY SYSTEMS, INC.

for the

U.S. DEPARTMENT OF ENERGY

under contract DE.ACO5-84OR21400

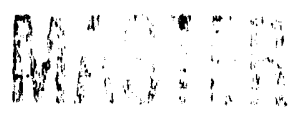


CONTENTS

Page

IIST OF FIGURES . . . . . . . . . . . . . . . . . . . . . . . vii

LIST OF TABLES . . . . . . . . . . . . . . . . . . . . . . . . . $1 \mathrm{X}$

LIST OF ACRONYMS , . . . . . . . . . . . . . . . X111

ACKNOWLEDGMENTS . . . . . . . . . . . . . . . . . . . . $\mathrm{xV}$

EXECUTIVE SUMMARY . . . . . . . . . . . . . . . . . xvil

1. INTRODUCTION . . . . . . . . . . . . . . . . . . . . . 1 . .

1.1 OBJECTIVES . . . . . . . . . . . . . . . . . . . 1.1

1.2 REVIEW OF PREVIOUS STUDIES . . . . . . . . . . . . . 1.-2

2. HABTTAT EVALUATION .................. . . . 2.1

2.1 REVIEW OF RECENT WATER QUALITY DATA . . . . . . . . . 2-2

2.1 .1 Surface Water . . . . . . . . . . . . . . . . . . 2-2

2.1.1.1 Organic Contaminants . . . . . . . . $2-2$

2.1.1.2 Inorganic Contaminants . . . . . . . . 2.4

2.1 .2 sediments .. . . . . . . . . . . . . . . 2.15

2.1.2.1 Organic Contaminants . . . . . . . . . 2.15

2.1.2.2 Inorganic Contaminants . . . . . . . . 2.19

2.2 FLOW AND THERMAL CHARACTERISTICS . . . . . . . . . . . . 2.22

2.2.1 Geohydrology . . . . . . . . . . . . . . . . . 2.22

2.2.2 Surface Water Hydrology . . . . . . . . . . . . . 2-24

2.2.2.1 Drought Effects . . . . . . . . . . 2.24

2.2.2.2 Importance of Springs . . . . . . . . . 2.33

2.2.3 Thermal Characteristics . . . . . . . . . . . . 2.33

2.3 SUBSTRATE AND COVER.................... 2.36

2.3.1 Introduction .................. 2.36

2.3.2 Methods . . . . . . . . . . . . . 2-36

2.3.3 Results . . . . . . . . . . . . . . . . . . $2-40$

2.3.3.1 Fish Study Sites.......... . $2-40$

2.3.3.2 Benthic Macroinvertebrate Study Sites . . 2.52

2.3.4 Discussion................ 2.56

3. TOXICITY MONITORING . . . . . . . . . . . . . . . . . . . . 3-1

3.1 INTRODUCTION . . . . . . . . . . . . . . . . . . . . . . 3-1

3.2 MATERIALS AND METHODS . . . . . . . . . . . . . . . . . . 3-2

3.2.1 Ambient Toxicity Tests . . . . . . . . . . . . . 3-2

3.2.2 In Situ Sna1l Tests . . . . . . . . . . . . . . 3-3

3.3 DATA ANALYSIS . . . . . . . . . . . . . . . . . . . . $3-4$

3.3.1 Ambient Toxicity Tests . . . . . . . . . . . . . 3-4

3.3 .2 In Situ Snall Tests . . . . . . . . . . . . . . 3-7 
3.4 RESULTS . . . . . . . . . . . . . . . . 3-7

3.4.1 Amblent Toxicity Test ... . . . . . . . 3-7

3.4.2 In situ Sna11 Tests . . . . . . . . . . . . . . 3-1.6

3.5 DISCUSSION . . . . . . . . . . . . . . . 3-22

4. FISHES . . . . . . . . . . . . . . . . . . 4-1

4.1 INTRODUCTION . . . . . . . . . . . . . . . . 4-1

4.2 KETHODS . . . . . . . . . . . . . . . . . . . . . . . 4-2

4.2.1 Population surveys ................. 4-2

4.2.2 Field Sampling Procedures . . . . . . . . . . . 4-2

4.2.3 Data Analys 1s . . . . . . . . . . . . . . . . . . 4-4

4.3 RESULTS..................... 4- . . . . 5

4.3.1 Species Richness and Composition . . . . . . . . 4-5

4.3.2 Density and Blomess ............... . 4-10

4.3.3 Condition Factors and Length-Frequency . . . . . . 4-15

4.4 CONCLUSIONS . . . . . . . . . . . . . . . . . . . . . . 4-21

5. BENTHIC MACROINVERTEBRATES . . . . . . . . . . . . . . 5-1

5.1 INTRODUCTION . . . . . . . . . . . . . . . . . . . . . . 5-1

5.2 MATERIALS AND METHODS .................. . 5-1

5.3 RESULTS. . . . . . . . . . . . . . . . . . 5-5

5.3.1 Taxonomic Composition . . . . . . . . . . . . 5.5

5.3.2 Density and Blomess . . . . . . . . . . . . . 5-7

5.3.2.1 Temporal and Spatial Patterns . . . . . . 5.7

5.3.2.2 Bear Creek vs Reference sites . . . . . . 5.18

5.3.2.3 Dominant Taxa . . . . . . . . . . . . 5-19

5.3.3 Commurity Structure . . . . . . . . . . . . . 5-27

5.3.3.1 Richness...... . . . . . . . 5-27

5.3.3.2 Species Diversity . . . . . . . . . . $5-34$

5.4 DISCUSSION .. . . . . . . . . . . . . . . . 5-40

6. FUTURE ECOLOGICAL CONDITIONS . . . . . . . . . . . . 6-1

6.1 REMEDYAL ACTIONS AND OTHER EXPECTED CHANGES . . . . . . 6-1

6.2 ANTICIPATED ECOLOGICAL CHANGES . . . . . . . . . . . . 6 6-2

6.3 FUTURE RESEARCH NEEDS . . . . . . . . . . . . . . . 6-3

7. REFERENCES . . . . . . . . . . . . . . . . . 7-1

APPENDIX A, MEAN MONTHLY TEMPERATURES IN BEAR CREEK, SOUTH SPRING 5, AND GRASSY CREEK, SEPTEMBER 1985-

DECEMBER 1987 . . . . . . . . . . . . . . . . A-1

APPENDIX B. DENSITY AND BIOMASS OF FISHES IN BEAR CREEK AND TWO

REFERENCE STREAMS, MAY 1984-NOVEMBER $1987 \quad$. . . . . B-1 
APPENDIX C. STATISTICAL COMPARISON OF FISH CONDITION FACTORS BETWEEN SAMPLING PERIODS AND BETWEEN SAMPLING SITES IN BEAR CREEK AND TWO REFERENCE STREAMS, 1984-1987 C-1

APPENDIX D. CHECKLIST OF BENTHIC MACROINVERTEBRATE TAXA FROM BEAR CREEK AND GRASSY CREEK, JUNE 1984-JULY 1987 , , D.1

APPENDIX E. CHECKLIST OF BENTHIC MAGROINVERTEBRATE TAXA FROM BEAR CREEK REFERENCE STREAMS, OCTOBER 1984JULY 1987

APPENDIX F. STATISTICAL COMPARISONS OF DENSITY AND BIOMASS OF BENTHIC MACROINVERTEBRATES . . . . . . . . , F-1

APPENDIX G, STATISTICAL COMPARISON OF RICHNESS AND DIVERSITY OF BENTHIC MACROINVERTEBRATES 


\section{LIST OF FIGURES}

1-1 Location of blological sampling sites on upper Bear Creek relative to burlal ground $A$, the sanitary landf111/o11 landfarm, and the S-3 ponds.......... 1-3

1-2 Location of blological sampling sites on lower Bear Creek . . . . . . . . . . . . . . . . . . . 1-5

2-1 Total dissolved solids in Bear ixseak surface water at BCK 12.46, 1983-1987... . . . . . . . . . . . . . . 2-8

2-2 Average mean concentrations of P.CBs in fine suxface sediments at varlous sites in Bear Creek, showing input of PCBs from tributaries draining the burlal grounds near BCK 10.3 and BCK 9.9

2-3 Monthly precipitation, as percent of average, at the NOAA meteorological station in Oak Ridge, 1984-1987

2-4 Comparison of total dally precipitation and the frequency of occurrence of zero flow in Bear Creek, 1985-1987... . . . . . . . . . . . . . . . . . . 2-30

2-5 Mean dally stream flow in Bear Creek at BCK 4.55, March 1985-December 1987 . . . . . . . . . . . . . . 2-32

2-6 Mean weekly temperatures in Bear Creek above SS5, fmmediately below SS5, and $1.54 \mathrm{~km}$ downstream. . . 2-35

2-7 Map of the Oak Ridge Reservation showing the location of the on-site and near off-site ecological reference sites . . . . . . . . . . . . . . . . . . . . 2-41

2-8 Map of the Oak Ridge area showing the location of the far off-site ecological reference sites . . . . . . . .

3-1 Positions of snalls 24 or 48 h after release at BCK 12.36

4-1 Total density for fish populations in Bear Creek, Grassy Creek, and Mill Branch, May 1984-November 1987 . . . . . . 4-13

4-2 Total biomass for fish populations in Bear Creek, Grassy Creek, and Mill Branch, May 1984-November 1987 . . . . . . 4-14

4-3 Length-frequency of blacknose dace at Bear Creek sites above and below the SS5 spring during July/August 1985 
4-4 Length-frequency of blacknose dace at Bear Creek sites above and below the SS5 spring during November/December 1985

4-5 Length-frequency of blacknose dace at Bear Creek sites above and below the SS5 spring during March/April 1986 . . 4-19

4-6 Change in mean length of three age classes of blacknose dace at Bear Creek sites above and below the SS5 spring during July 1985 to March 1986 ............... 4-20

5-1 Density of benthic macroinvertebrates in Bear Creek and Grassy Creek, June 1984-July 1987 . . . . . . . . . . . . 5-14

5-2 Density of benthic macroinvertebrates in Bear Creek reference streams, October 1984-July 1987 . . . . . . . . 5-15

5-3 Blomass of benthic macroinvertebrates in Bear Creek and Grassy Creek, June 1984-July 1987 . . . . . . . . . . . . 5-16

5-4 Blomass of benthic macroinvertebrates in Bear Creek reference streams, October 1984-July 1987 . . . . . . . . 5-17

5-5 Number of benthic macroinvertebrate taxa per sample in Bear Creek and Grassy Creek, June 1984-July 1987... . . 5-35

5-6 Number of benthic macroinvertebrate taxa per sample in Bear Creek reference streams, October 1984-July 1987.. . 5-36

5-7 Taxonomic diverst.ty of benthic macrolnvertebrates in Bear Creek and Grassy Creek, June 1984-July 1987 . . . . . 5-38

5-8 Taxonomic diversity of benthic macroinvertebrates in Bear Creek reference streams, October 1984-July 1987 


\section{LIST OF TABLES}

Tab1e

Page

1-1 Mean densities of benthic invertebrates in Bear Creek, 1974-1975

1-2 Number of benthic invertebrate taxa, by order/family, collected by quantitative and qualltative sampling in lower Bear Creek and Grassy Creek, May 1975-Apr11 1976... . . 1-9

1-3 List of fish specles collected from Grassy Creek and lower Bear Creek in 1974-1975 and from lower Bear Creek In 1984 .. . . . . . . . . . . . . . . . . . . . 1-10

1-4 Mean pH of Bear Creek in three surveys conducted over the past 10 years . . . . . . . . . . . . . . . . . . . . . . 1-14

2-1 Summed concentrations of volatile organics in Bear Creek surface water at variuus sites.............. 2-3

2-2 Dilution of upper Bear Creek solutes in Bear Creek . . . . 2-6

2-3 Concentrations of major lons in unfiltered Bear Creek water at varlous sites downstream from the s-3 ponds...... 2-9

2-4 Maximum concentrations, acute toxicity ranges, and water quality criteria for Inorganic lons found at elevated levels in Bear Creek

2-5 Concentrations of metals in water from Bear Creek and the S-3 plume that were associated with toxiclty to Ceriodaphnia . . . . . . . . . . . . . . . . 2-11

2-6 Concentrations of metals in Bear Creek sediments that are elevated relative to concentrations in Grassy Creek, a reference stream . . . . . . . . . . . . . 2-20

2-7 Frequency and duration of zero-flow pexiods in Bear Creek, 1984-1987.................... 2-23

2-8 Hean, $S D$, and range of stream flows in $L / s$ for Bear Creek and selected tributaries, 1985-1987

2-9 Comparison of precipitation for two perlods of the year with contrasting evapotranspiration rates and groundwater recharge rates, 1983-1988 . . . . . . . . . . 2-28

2-10 Substrate codes used in the phystcal habitat analysis of Bear Creek . . . . . . . . . . . . . . . . . . . 2-38

2-11 Embeddedness rating for substrate material ........ 2-39 
2-12 Stream order, total length, mean width, mean depth, and surface area of fish sampling sites in Bear Creek and two reference streams, Grassy Creek and Mill Branch, 1984-1987

2-13 Substrate rating, embeddedness rating, percent canopy, and $P / R$ ratio for fish sampling sites in Bear Creek and two reference streams, Grassy Creek and Mill Branch, June 1988

2-14 Mean and maximum current velocity and mean depth for each transect and for the entire reach/site at the fish and benthic invertebrate sampling stations on Bear Creek, Bear Creek Tributary, Clear Creek, Grassy Creek, Gum Hollow Branch, Hinds Creek, Mill Branch, Plnhook Branch, UT Farm Creek, and Walker Branch, June 1988 . . . . . . . . . .

2-15 Stream order, substrate rating, embeddedness rating, and percent canopy for benthic macrolnvertebrate sampling sites on Beax Creek, Grassy Creek, Mill. Branch, Bear Creek Tributary, Pinhook Branch, Gum Hollow Branch, UT Farm Creek, Walker Branch, Hinds Creek, and Clear Creek, June 1988

3-1 Schedule used to evaluate ambient toxiclty of water from Bear Creek and selected tributarles with fathead minnow Iarvae

3-2 Percent survival of fathead minnow larvae in eight toxicity tests of water from nine sampling sites on Bear Creek. . 3-8

3-3 Mean growth of fathead minnow larvae in water from nine sites on Bear Creek . . . . . . . . . . . . . . . . . . . 3-8

3.4 Results of two-way ANOVA for survival and growth of fathead minnow larvae in toxiclty tests of water from varlous sites in Bear Creek

3-5 Percent survival of fathead minnow larvae tested with water collected from two sites in Grassy Creek. . . . . . . . .

3-6 Number of Ceriodaphnia survivors and their fecundity in water from varlous Bear Creek sites . . . . . . . . . . . 3-12

3-7 Mean survival and mean growth of fathead minnow larvae in water from six sites in Beax Creek. . . . . . . . . . .

3-8 Number of Ceriodaphnia survivors and their fecundity in water from varlous Bear Creek sites 
3-9 Conductivity of water collected from varlous Bear Creek sites . . . . . . . . . . . . . . . . . . . 3-17

3-10 Results of the dally chemical analyses conducted for Ceriodaphnia and fathead minnow larvae toxicity tests of water from six sites in Bear Creek . . . . . . . . . . .

3-11 Summary of chemical analyses of water from Bear Creek sttes during April 27-May 4, 1989 . . . . . . . . . . . . . .

3-12 Within-test survival of fathead minnow larvae in toxicity tests of water from three sites on Bear Creek and four sites on tributaries of Bear Creek . . . . . . . . . .

3-13 Mean conductivity and $\mathrm{pH}$ of control water and of water collected from two sites on Grassy Creek . . . . . . . . . 3-26

3-14 Number of Ceriodaphnia test endpoints passed or falled in Bear Creek samples in relation to conductivity. . . . . .

4-1 Fish species composition in Bear Creek and two reference streams, Grassy Creek and Mill Branch, for the period May 1984-November 1987

4-2 Trophic structure and intolerance of fish communties in Bear Creek, Grassy Creek, and Mll1 Branch based on sampling conducted from May 1984 through November 1987 . . . . . .

4-3 Total fish density, total biomass, and species richness for May 1985 through November 1987 In Bear Creek and two reference streams, Grassy Creek and Mill Branch

5-1 Sampling sites and schedule for benthic macroinvertebrate collections in Bear Creek and reference streams . . . . . 5-2

5-2 Mean density and biomass of benthic macroinvertebrate in Bear Creek and reference sites, June 1984-July 1987 . . . 5-8

5-3 Relative density of dominant benthic macroinvertebrate taxa in Bear Creek and reference streams, June 1984-July 1987

5-4 Relative biomass of dominant benthic macroinvertebrate taxa in Bear Creek and reference streams, June 1984-July 1987

5-5 Total richness, mean richness, and diversity of benthic macrolnvertebrates in Bear Creek and reference sites, June 1984-July 1987 . . . . . . . . . . . . . . . . . . . . . . 


\section{LIST OF ACRONYMS}

\begin{tabular}{|c|c|}
\hline$A C D$ & Analytical Chemistry Division \\
\hline ANOVA & Analysis of variance \\
\hline ASG & Automated Sciences Group, Inc. \\
\hline ATDL & Atmospheric Turbulence and Diffusion Laboratory \\
\hline $\mathrm{BCK}$ & Bear Creek kilometer \\
\hline BTK & Bear Creek Tributary kilometer \\
\hline $\mathrm{CCK}$ & Clear Creek kilometer \\
\hline CV & Coefficient of variation \\
\hline EAD & Environmental Affairs Department \\
\hline EFPC & East Fork Poplar Creek \\
\hline ENFRRC & Exxon Nuclear Fuel Recovery and Recycling Center \\
\hline EPA & Environmental Protection Agency \\
\hline ERDA & Energy Research and Development Administration \\
\hline ESD & Environmental Sciences Division \\
\hline ET & East tributary \\
\hline GCK & Grassy Creek kilometer \\
\hline GHK & Gum Hollow Branch kilometer \\
\hline GLM & General Linear Model \\
\hline $\mathrm{HCK}$ & Hinds Creek kilometer \\
\hline HSEAD & Health, Safety, Environment, and Accountability Division \\
\hline ICAP & Inductively coupled argon plasma emission spectroscopy \\
\hline MBK & Mill Branch kilometer \\
\hline NOAA & National Oceanic and Atmospheric Administration \\
\hline NPDES & National Pollutant Discharge Elimination System \\
\hline NT & North tributary \\
\hline ORGDP & Oak Ridge Gaseous Diffusion Plant \\
\hline ORNL & Oak Ridge National Laboratory \\
\hline ORR & Oak Ridge Reservation \\
\hline $\mathrm{P} / \mathrm{R}$ & Pool-to-riffle \\
\hline PAHs & Polycyclic aromatic hydrocarbons \\
\hline PCBs & Polychlorinated biphenyls \\
\hline PHK & Pinhook Branch kilometer \\
\hline $\mathrm{ppb}$ & Parts per billion \\
\hline ppm & Parts per million \\
\hline $\begin{array}{l}\text { SAS } \\
\text { SS }\end{array}$ & $\begin{array}{l}\text { Statistical Analysis System } \\
\text { South spring }\end{array}$ \\
\hline $\begin{array}{l}\text { SS } \\
\text { ST }\end{array}$ & $\begin{array}{l}\text { South spring } \\
\text { South tributary }\end{array}$ \\
\hline TVA & $\begin{array}{l}\text { South tributary } \\
\text { Tennessee Valley Authority }\end{array}$ \\
\hline UCCND & Union Carbide Corporation-Nuclear Division \\
\hline USGS & United States Geological Survey \\
\hline UTK & University of Tennessee Farm Creek kilometer \\
\hline VOCs & Volatile organic compounds \\
\hline WBK & Walker Branch kilometer \\
\hline WCK & White Oak Creek kilometer \\
\hline WT & West tributary \\
\hline YOY & Young-of-the-year. \\
\hline
\end{tabular}




\section{ACKNOWLEDGMENTS}

We thank all those individuals who assisted with the field sampling, including R. D. Bailey, P. W. Braden, D. K. Cox, G. J. Haynes, L. A. Kszos, W. C. Kyker, L. M. Stubbs, and L. F. Wicker of the Oak Ridge National Laboratory (ORNL) Environmental Sciences Division (ESD); W. M. Harris, M. J. Peterson, and E. M. Schilling of Automated Sciences Group, Inc. (ASG); and B. C. Harvey of Weber State College. Substantial support was provided by the staff of the ESD toxicity testing laboratory, including L. A. Kszos, R. D. Bailey, P. W. Braden, L. S. Ewald, G. J. Haynes, G. P. Morris, J. Richmond, and L. F. Wicker. We thank N. M. Ferguson and J. H. Stewart and their respective staffs of the ORNL Analytical Chemistry Division (ACD) for chemical analyses. C. Kimbrough and her staff of the Oak Ridge Y-12 Plant/Health, Safety, Environment, and Accountability Division provided samples for testing and analysis, and $R$. R. Turner of ESD provided references and summaries of contaminant data. We thank M. J. Peterson (ASG) for taxonomic identification of terrestrial plants and descriptions of riparian plant communities; and T. W. Toole, K. Tennessen, L. Young, J. Walden, and other staff of the Tennessee Valley Authority Aquatic Biology Laboratory in Muscle Shoals, Alabama, for taxonomic identification and enumeration of benthic invertebxates. J. J. Beauchamp (ORNL Computing and Telecommunications Division) provided statistical assistance. Finally, we are grateful to R. R. Turner, B. T. Walton, and S. F. Railsback (ESD) who reviewed the draft report and provided many helpful comments and suggestions.

This work was funded by the Y-12 Plant Department of Environmental Management; Health, Safety, Environment, and Accountability Division. The Y-12 Plant and ORNL are managed by Martin Marietta Energy Systems, Inc., for the U.S. Department of Energy under contract number DE-AC05-840R21400. 


\section{EXECUTIVE SUMMARY}

Ecological studies of the Bear Creek watershed, which drains the area surrounding several Oak Ridge Y-12 Plant waste disposal facilities, were initiated in May 1984. These studies consisted of an initial, detailed characterization of the benthic invertebrate and fish communities in Bear Creek, and they were followed by a presently ongoing monitoring phase that involves reduced sampling intensities. The characterization phase utilized two approaches: (1) instream sampling of benthic invertebrate and fish communities in Bear Creek to identify spatial and temporal patterns in distribution and abundance and (2) laboratory bioassays on water samples from Bear Creek and selected tributaries to identify potential sources of toxicity to biota. The monitoring phase of the ecological program relates to the long-term goals of identifying and prioritizing contaminant sources and assessing the effectiveness of remedial actions. It continues activities of the characterization phase at less frequent intervals.

Bear Creek contains adequate physical habitat to maintain and propagate aquatic life throughout its length, with the lower reaches having increased habitat diversity as is typical of most small streams. Riparian vegetation provides shade and cover throughout the creek's length, and the bottom substrate of rubble, gravel, and sand is adequate at all sites except Bear Creek kilometer (BCK) 12.36, where the predominantly hard clay substrate provides an inferior habitat for aquatic 1 ife.

Much of Bear Creek is closely associated with the Maynardville limestone formation, which contains numerous solution cavities and channels capable of sustaining subsurface flow. Large springs on the north slope of Chestnut Ridge have a significant effect on the hydrology of Bear Creek, acting to stabilize flows during periods of low flow and to moderate temperature extremes. Flow in some portions of Bear Creek between BCK 1.1 .64 and BCK 9.45 and between BCK 7.87 and BCK 4.60 is intermittent, and periods of no surface flow commonly occur in summer and fall. The frequency and duration of no-flow conditions is highest 
in upper Bear Creek. Annual precipitation in the vicinity of Bear Creek watershed was below normal in four of the five years (1983-1987) pertinent to this study and far below normal ( $<75$ of the 1951-1980 norm) in 1986 and 1987, with much of the shortfall occurring during the winter months when most groundwater recharge occurs. As a result, surface flows in Bear Creek were unusually low during much of the study period.

Chemical water quality of Bear Creek is not typical of urimpacted streams in the region because or high concentrations of dissolved salts (primarily calclum, magnesium, sodium, potasslum nitxate, chloride, bicarbonate, and sulfate) resulting from the infiltration of contaminated groundwater in the vicinity of the $5-3$ ponds. Concentrations of these major constituents in Bear Creek downstream from BCK 12.36 roughly approximate those expected frim the dilution of flow at the uppermost site with uncontarinated groundwater and surface flow from tributaries. Trace fons (armonta, bartum, berjlilum, cadmium, cobalt, copper, manganese, wead, nickel, silver, uranium, and zinc) are elevated in the uppermost reaches of Bear Creek but decline to background or below detection linits whin a short distance downstream. Lithium and boron are elevated below the burial grounds. Several metals are clearly elevated in sediments in the upper reaches of Bear Creek: cadmium, copper, lithium, nickel, uranfum, and zinc.

Organic contamirants in Bear Creek are chlorinated solvents and. theil degradation products (primarily tetrachloroethene, trichloroethene, dichloroethene, and viriyl chloride) and polychlorinated biplienyls (PCBs). The solvents, referred to as volatile organic compounds (VOCs), enter Bear Creek through north tributaries (NTs) draining the burial grounds (NT7 and NT8) and are rapldly dissipated by volatilization within several hundred meters. PCBs also enter Bear Creek via these tributaries and at evident in sediments and biota downstreala.

Ambient (instream) toxicity was evaluated at varlous sites in Bear Creek, as well as several of lts tributarles, and at Grassy Creek, a nearby reference stream, eight times from June 1984 to March 1988 
using growth and surviral of fathead ininnoiv ('tnephales promelas) larvae as toricity endpoints. Toxicity of water samples from six sites in Bear Creek was also evaluated in March 1988 anc March 1989 using survival and reproduction of the microcrustacean Ceriodaphnia dubia as toxicity endpoints. In-situ tests of acute toxicity of Bear Creek water to snails (Elimia clavaeformis) were conducted at four sites in Bear Creek in 1986 and 1987. Behavioral studies evaluating the movement of snails after placement in various sections of Bear Creek were also conducted.

Results of the ambient toxicity tests demonstrated that water at BCK 12.36 was toxic to fathead minnows on six of nine test dates, but no consistent pattern of toxicity was observed at any sites farther downstream. Bear Cresk water that was not toxic to fathead minnow larvae was toxic to Ceriodaphnia at $B C K 12.36$ and $B C K 11.83$ in March 1988, when stream flow was higher and solutes were more dilute than usual, and again in March 1989, when stream flow was normal. The Ceriodaphnia test appcared to be at least a factor of two to three times more sensftive than the fathead mirnow test in detecting toxicity in Bear Creek water.

In-situ studies with snalls found an increasing percentage of snails to be dead or stressed with increasing proximfty to the uppermost site ( $B C K$ 12.36). In behavioral studies, snails released in Bear Creek tended efther to remain at the site of release or to move downstream, while those released in uncontaminated reference streams consistently moved upstream.

Nineteen species of fish were found in quantitative sampling of the fish community in Bear Creek. Electroshocking surveys were conducted periodically from May 1984 to December 1987 at seven sites in Bear Creek and at reference sites in Grassy Creek and Mill Branch. Minnows (blacknose dace, Rhinichthys atratulus; Tennessee dace, Phoxinus tennesseensis (-oreas); stoneroller, Campostoma anomalum; and creek chub, Semotilus atromaculatus] were the predominant consituents of the fish fauna upstream from the weir at BCK 4.55. Below the weir, which acts as a barrier to the upstream migration of fish, larger species 
(northern hog sucker, Hypentelium nigricans; white sucker, Catostomus comnersoni; and rock bass, Ambloplites rupestris) were more common. Also, the diversity of minnow species increased and darters were found downstream of $\mathrm{BCK} 4.55$.

These studies concluded that much of Bear Creek 'ad a limited fish fauna (low species richness) characterized by robust population parameters (high densities and biomass). The upper ost site (BCK 12.36) did not have a stable, resident fish population. Water from this site was commonly toxic to fathead minnow larvae in laboratory bioassays and contained high levels of dissolved salts as a result of inputs of contaminated groundwater from the S.3 pond site. The next two monitoring sites downstream, BCK 11.83 and BCK 11.09, had low fish density and blomass in 1984 and 1985 but showed recovery in later sare ling. No impacts on the fish fauna of Bear Creek were evident in the vicinity of inputs from the burial grounds (BCK 9.91 and BCK 9.40), despite qualitative surveys that found no fish to be present in tributaries (NT6-NT8) draining the site. Lower Bear Creek (BCK 3.25) contained a diverse assemblage of fish similar to Mill Branch, the larger reference stream, while upper Bear Creek contained fauna similar to that of Grassy Creek, the smaller reference stream similax in size.

No endangered or threatened fish species have been found in Bear Creek; however, the Tennessee dace, which was formerly classified as the mountain redbelly dace (Phoxinus oreas) and reclassified by Starnes and Jenkins (1988), is a major constituent of the fish population above the weir at BCK 4.55. This fish is listed as a species in need of management, and its habitat is protected by the state of Tennessee. In Bear Creek this fish occurs at every site above the weir and in at least four tributaries (NT13, NT14, NT18, and ST7).

Quantitative sampling of benthic invertebrates was conducted monthly at nine sites between BCK 12.36 and BCK 3.25 from June 1984 through May 1985 during the initial characterization phase of the ecological monitoring program for Bear Creek and at quarterly intervals thereafter. A total of 126 distinguishable taxa were collected in Bear Creek, including crustaceans (Isopoda, Amphipoda, and Decapoda); 
aquatic worms (Oligochaeta); snails (Gastropoda); mussels (Pelecypoda); and insects (Insecta). Eleven orders of insects were collected in Bear Creek including springtails (Collembola), mayflies (Ephemeroptera), dragonflies and damselflies (Odonata), crickets and grasshoppers (Orthoptera), stoneflies (Plecoptera), true bugs (Hemiptera), alderflies and fishflies (Megaloptera), caddisflies (Trichoptera), butterflies and moths (Lepidoptera), beetles (Coleoptera), and true flies (Diptera).

The invertebrate fauna of Bear Creek showed a pattern of increasing density, biomass, and taxonomic diversity and richness with increasing distance downstream from the uppermost sampling site (BCK 12.36). The paucity of benthic invertebrates found in the upper reaches of Bear Creek contrasted sharply with reference sites (unimpacted streams of similar size), which had relatively diverse and abundant assemblages of macroinvertebrates. While evidence of adverse effects on the fish communities of Bear Creek was not noted at sites downstream from BCK 11.83, the benthic fauna appeared to be more sensitive, with clear differences in faunal composition from unimpacted reference sites at all sites except BCK 3.25, where no impact was evident. Species intolerant of pollution (mayflies, stoneflies, and caddisflies) were absent in the upper reaches and became more common downstream. Mayflies, which are particularly sensitive to toxic metals, were virtually absent at all sites except $B C K$ 3.25. Unlike the fish data, which provide evidence of ecological recovery in Bear Creek since 1984, the benthic macroinvertebrate fauna does not appear to have changed in a manner indicative of either improving or degrading water quality since 1984. No threatened or endangered species of aquatic macroinvertebrates have been collected in Bear Creek.

Future studies in Bear Creek will continue routine monitoring at the present level and include detailed studies of the life history of protected species (the Tennessee dace) found in Bear Creek. These studies will continue to document the effectiveness of remedial actions and will provide a scientific basis for evaluating the response of the Tenmssee dace to habitat alterations associated with the proposed remedial actions. 


\section{INTRODUCTION}

The Bear Creek Valley is a watershed that drains the area surrounding several closed Oak Ridge Y-12 Plant waste disposal facilities. Past waste disposal practices in Bear Creek Valley resulted in contamination of Bear Creek and consequent ecological damage. Extensive remedial actions have been proposed at waste sites, and some have been implemented or are now underway. Ecological studies of the Bear Creek watershed were initiated in May 1984 and are continuing at present. The proposed study plan consists of an initial, detailed characterization of the benthic invertebrate and fish communities in Bear Creek in the first year followed by a reduction in sampling intensity during the monitoring phase of the plan. The results of sampling conducted from May 1984 through early 1989 are presented in this report.

\subsection{OBJECTIVES}

The objectives of the ecological studies on Bear Creek are (1) to assist in the development of an effective remedial action plan related to past waste disposal operations in Bear Creek Valley and (2) to evaluate the effectiveness of these actions by monitoring the ecological recovery of Bear Creek. To accomplish the short-term goal of assessing potential ecological consequences of various remedial action alternatives (Objective 1), studies were conducted to characterize the existing environment in Bear Creek. This characterization utilized two approaches: (1) instream sampling of the benthic invertebrate and fish communities in Bear Creek to identify spatial and temporal patterns in distribution and abundance and (2) laboratory bioassays on water samples from Bear Creek and selected tributaries to identify potential sources of toxicity to biota.

The second objective of the ecological program relates to the long-term goal of identifying and prioritizing contaminant sources and assessing the effectiveness of major remedial actions that are implemented to mitigate the impacts of past waste disposal operations in Bear Creek Valley. Following completion of the initial characterization 
studies in July 1985, periodic monitoring is being conducted to assess ecological recovery in Bear Creek.

\subsection{REVIEW OF PREVIOUS STUDIES}

Limited information is available on the past ecology of Bear Creek. The first studies were conducted in August 1972 and 1973 and consisted of qualitative surveys of the benthic invertebrate communities (McClain 1972; Reece 1973). Results of both studies indicated a paucity of benthic invertebrates and an absence of fish (personal observations only) in Bear Creek above approximately Bear Creek kilometer ( $B C K$ ) $11.2^{*}$ at the west end of the sanitary landfill/oil landfarm area (Fig. 1-1). They also reported precipitates of aluminum hydroxide on the stream bed at and above this same location. The pH of Bear Creek in this area was 6.0 in 1972 but below 4.5 in 1973. McClain (1972) observed fish just above the burial grounds in 1972 at a site that was reported by Reece (1973) to be dry the following year.

The Energy Research and Development Administration (ERDA) conducted quantitative sampling of the benthic invertebrate and fish communities at four sites on Bear Creek between September 1974 and March 1975 (ERDA 1975). Although adequate information is provided on benthos sampling techniques (i.e., Surber sampler with a $253-\mu \mathrm{m}-m e s h$ collection net), the description of fish sampling was sketchy, referxing only to electrofishing a 50-m reach of stream at each site in December, January, and March. No organisms were found in upper Bear Creek at sites BCK 11.9 and $B C K$ 11.1 located just above and below the sanitary landfill/oil landfarm area, respectively (Fig. 1-1). In addition, no fish survived in a $24 \mathrm{~h}$ in situ bioassay at sites just above and $500 \mathrm{~m}$ below the sanitary landfill (approximately BCK 11.8 and BCK 10.8, respectively).

During the sane survey, sampling was conducted in lower Bear Creek at a site (BCK 4.3) $25 \mathrm{~m}$ below the Y-12 Plant National Pollutant Discharge Elimination System (NPDES) monitoring station and at a site

${ }^{*} B C K 0.0$ is located at the mouth of the creek. This same system is used to designate sampling sites on other streams mentioned in this report (e.g., WCK 6.8 white Oak Creek kilometer 6.8). 


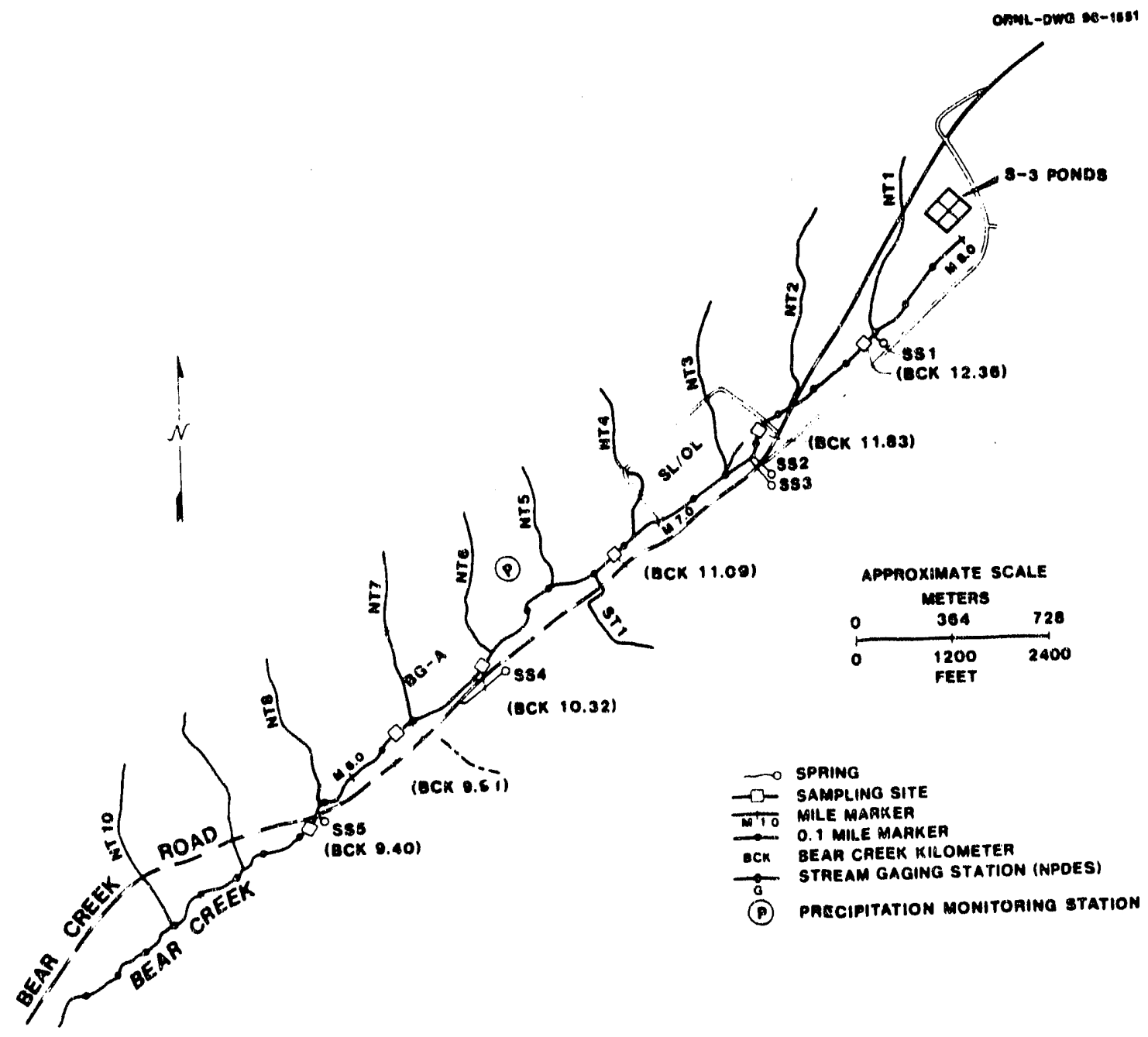

Fig. 1-1. Location of blological sampling sites (BCK) on upper Bear Creek relative to burfal ground A (BG-A), the sanitary landill/oil landfarm (SL/OL), and the $S-3$ ponds. Not shown are the upper (northern) portion of BG-A and burial grounds $B, C$, and $D$, which are located northwest of BG-A. Distance (km) from the confluence with East Fork Poplar Creek is given in parentheses. 
near BCK 1.8 (Fig. 1-2). The density and diversity of Ephemeroptera (mayflies), a generally pollution-intolerant group, were lower at the upstream site (Table 1-1). Total density and number of benthic invertebrate species were also lower at BCK 4.3 compared to $B C K 1.8$. A similar pattern was observed for the fish community; 3 species were collected at BCK 4.3 (total of 6 individuals for the 3 sampling dates) and 7 species (total of 32 individuals) were found at BCK 1.8. At each site, no fish were collected on at least one of the three sampling dates. More intensive sampling conducted the same year near the same two sites revealed a much more diverse community at BCK 4.3 and one that was similar in species composition to that found at BCK 1.8 (Exxon Nuclear, Inc., 1976). Rather than indicating a highly impacted fish community in lower Bear Creek 10 years ago, results of the ERDA (1975) survey may instead reflect an underestimation of $\mathrm{fish}$ abundance and diversity. The efficiency of sampling by electrofishing can be significantly reduced by high flows and the resultant high turbidity levels that typically occur during the winter. The low fish abundance reported in the ERDA (1975) survey is also inconsistent with the results of water quality analyses conducted during the same survey, as discussed in Sect. 2.1.

The first intensive survey of the benthic invertebrate and fish cornmunities in Bear Creek was conducted from May 1975 through April 1976 (Exxon Nuclear, Inc., 1976) and also included sites on both Grassy Creek, a smal1, relatively unimpacted watershed adjacent to the Bear Creek watershed (Sect. 2.3.3.1), and the Clinch River. This survey was to provide preoperational baseline data that would be used to assess the potential environmental impacts related to construction and operation of the Exxon Nuclear Fuel Recovery and Recycling Center (ENFRRC) at a proposed site near Clinch River kilometer 23.2 (just above Gallaher Bridge on Route 58). Sampling on Bear Creek was limited to three sites on the lower reaches: $\mathrm{BCK} 4.8, \mathrm{BCK} 1.9$, and $\mathrm{BCK} 0.8$. Although identified as BCK 4.8 in Exxon Nuclear, Inc. (1976) and Morton (1978), which would place it above the Y-12 Plant NPDES monitoring station (Fig. 1-2), the actual sampling site was below the station (E. Morgan, ENFRRC Project Leader, Tennessee Technological University, personal 


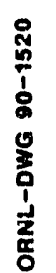

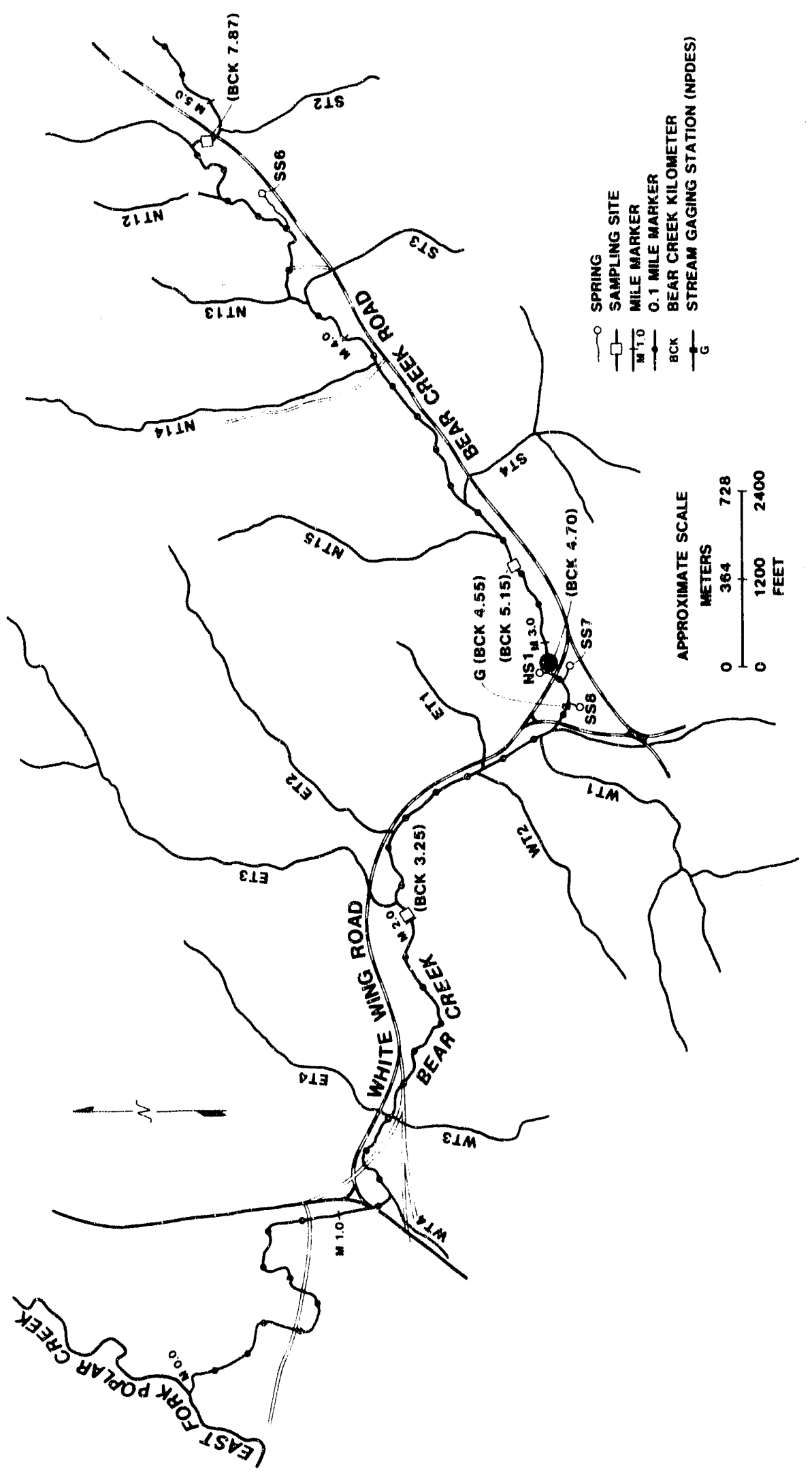

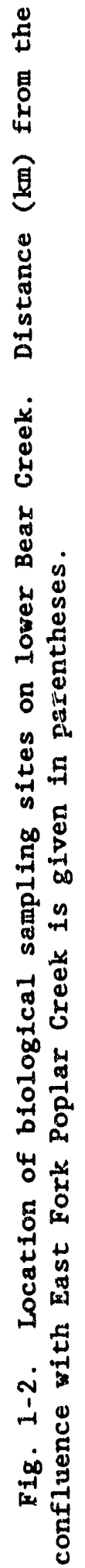


Table 1-1. Mean densities (number of organisms/0.1 $\mathrm{m}^{2}$ ) of benthic invertebrates in Bear Creek, 1974-1975. Three surber samples (253- $\mu$ m mesh net) were collected from riffle areas at each site on each of four sampling dates between September 1974 and March 1975

\begin{tabular}{|c|c|c|}
\hline \multirow[b]{2}{*}{ Taxon } & \multicolumn{2}{|c|}{ Sampling site } \\
\hline & BCK 4.3 & $\mathrm{BCK} 1.8$ \\
\hline \multicolumn{3}{|l|}{ Amphipoda } \\
\hline Gammarus & 1.4 & -- \\
\hline Crangonyx & 0.2 & $\cdots$ \\
\hline Synurella & 0.2 & $\cdots$ \\
\hline \multicolumn{3}{|l|}{ Coleoptera } \\
\hline Ectoparia & $\cdots$ & 0.1 \\
\hline Helichus & 0.1 & -- \\
\hline Optiosenvis & 0.1 & 3.8 \\
\hline Stenelmis & $\cdots$ & 0.1 \\
\hline \multicolumn{3}{|l|}{ Decapoda } \\
\hline Cambarus & 0.1 & 0.4 \\
\hline \multicolumn{3}{|l|}{ Diptera } \\
\hline Antocha & $\cdots$ & 0.9 \\
\hline Chironomidae & 9.0 & 9.9 \\
\hline Dicranota & -- & 0.2 \\
\hline Hemerodromia & -- & 0.5 \\
\hline Pseudolimnophilia & - & 0.1 \\
\hline Simulium & -- & 0.3 \\
\hline Tabanus & - & 0.1 \\
\hline Ti pula & 0.7 & 0.3 \\
\hline \multicolumn{3}{|l|}{ Ephemeroptera } \\
\hline Caenis & $\cdots$ & 0.1 \\
\hline Ephemera & $\cdots$ & 0.4 \\
\hline Ephemerella & 0.7 & 0.5 \\
\hline Habrophlebia & 0.2 & -- \\
\hline Stenonema & -- & 2.6 \\
\hline \multicolumn{3}{|l|}{ Gastropoda } \\
\hline Goniobasis & $\cdots$ & 0.3 \\
\hline \multicolumn{3}{|l|}{ Hemiptera } \\
\hline Callicorixa & 0.1 & $\cdots$ \\
\hline \multicolumn{3}{|l|}{ Hydracarina } \\
\hline Lebertia & 0.1 & $\cdots$ \\
\hline
\end{tabular}


Table 1-1 (continued)

\begin{tabular}{|c|c|c|c|}
\hline \multirow[b]{2}{*}{ Taxon } & \multicolumn{3}{|c|}{ Sampling site } \\
\hline & BCK 4.3 & & $\mathrm{BCK} 1.8$ \\
\hline \multicolumn{4}{|l|}{ Isopoda } \\
\hline Asellus & 0.2 & & $\cdots$ \\
\hline Lirceus & 0.1 & & 2.2 \\
\hline Nematoda & - & & 0.2 \\
\hline \multicolumn{4}{|l|}{ Neuroptera } \\
\hline Nigronia & $\cdots$ & & 0.1 \\
\hline Sialis & 0.1 & & $\cdots$ \\
\hline \multicolumn{4}{|l|}{ Odonata } \\
\hline Agrion & -- & & 0.1 \\
\hline Lanthus & 0.1 & & $-\cdot$ \\
\hline \multicolumn{4}{|l|}{ Oligochaeta } \\
\hline Lumbriculidae & $\cdots$ & & 0.1 \\
\hline Tubificidae & 0.2 & & $0 . \Omega$ \\
\hline \multicolumn{4}{|l|}{ Plecoptera } \\
\hline Leuctra & 0.2 & & 0.1 \\
\hline Nemoura & 0.7 & & -- \\
\hline \multicolumn{4}{|l|}{ Trichoptera } \\
\hline Cheumatopsyche & 0.1 & 10.0 & \\
\hline Chimarra & 0.2 & & 2.4 \\
\hline Total number of species & 21 & 26 & \\
\hline Total density & 14.5 & 35.7 & \\
\hline
\end{tabular}

Source: ERDA (1975), Table 2, p. 7. 
communication to G. F. Cada, Oak Ridge National Laboratory, Environmental Sciences Division, May 31, 1985). Thus, BCK 4.3 was the approximate location of the benthic invertebrate sampling site and the upper end of the fish sampling reach.

As in the ERDA (1975) study, species richness was lowest at the upstream site ( $B C K$ 4.3), and the number of Ephemeroptera species (4) was less than half the number found at the 2 downstream sites (10 at each site) or in Grassy Creek at Grassy Creek kilometer (GCK) 3.5 where 8 species were found and at GCK 1.6 where 11 species were found (Table 1-2). No abundance data are presented because a 1024- $\mu$-mesh Surber sampler was used (Morton 1978), and densities of smaller organisms, especially chironomid larvae, would be underestimated because of the large mesh size of the collection net. Fish samples were collected by electroshocking on five dates between September 1975 and April 1976. The fish communities at the three sites were similar in both species composition and the total number of species (Table 1-3). In addition, the fish community that existed at BCK 0.8 in 1975 was similar in species composition to that observed by the Tennessee Valley Authority (TVA) in 1984 near the same location (Table 1-3).

The only biological sampling conducted in Bear Creek since 1976 was a limited reconnaissance survey of small streams near the burial grounds on December 20, 1983, and January 6-8, 1984 (J. M. Loar, ORNL/ESD, 1984, personal communication to M. G. Ryon, ORNL/ESD). Seni-quantitative benthic invertebrate and fish sampling were conducted in Bear Creek above and below the confluence with north tributary (NT) 7 , in the lower reaches of NT7, and in a nearby small, intermittent south tributary (ST) that originates on the north slope of Chestnut Ridge (Fig. 1-1). Three benthic invertebrate samples were collected at each site by a modified kick-seining technique; organisms were subsequently identified to family or order in the laboratory. Fish sampling was conducted by electrofishing a 70 - to $115-\mathrm{m}$ reach ( $22 \mathrm{~m}$ in NT7); one pass was made upstream and downstream using the same equipment described in Sect. 4.2.2. Benthic invertebrate densities were very low at all three sites compared with the ST. Only blacknose dace (Rhinichthys atratulus) and creek chubs (Semotilus atromaculatis) were found in the ST, whereas 
Table 1-2. Number of benthlc invertebrate taxa, by order/family, collected by quantitative and qualitative sampling in lower Bear

Creek and Grassy Creek, May 1975-April 1976 (n = 60 samp]es collected at each site except GCK 3.5 , where $n=36$ )

\begin{tabular}{|c|c|c|c|c|c|}
\hline & \multicolumn{5}{|c|}{ Sampling site } \\
\hline & \multicolumn{3}{|c|}{ Bear Creek } & \multicolumn{2}{|c|}{ Grassy Creek } \\
\hline & BCK «: 3 & $\mathrm{BCK} 1.9$ & $\mathrm{BCK} 0.8$ & GCK 3.5 & $\overline{G C K ~} 1.6$ \\
\hline Amphipoda & 3 & 1 & -- & 3 & $-\cdot$ \\
\hline Coleoptera & 4 & 5 & 4 & 8 & 9 \\
\hline Collembola & 1 & $\cdots$ & $\cdots$ & 2 & 1 \\
\hline Decapoda ${ }^{a}$ & $\mathrm{x}$ & $\mathrm{x}$ & $\mathrm{x}$ & $x$ & $\mathrm{x}$ \\
\hline \multicolumn{6}{|l|}{ Diptera } \\
\hline Chironomidae & 11 & 14 & 8 & 15 & 1.0 \\
\hline Non-Chironomidae & 4 & 8 & 4 & 13 & 9 \\
\hline Ephemeroptera & 4 & 10 & 10 & 8 & 11 \\
\hline Hemiptera & 4 & 5 & 4 & 5 & 7 \\
\hline Hydracarina ${ }^{a}$ & 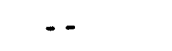 & $\cdots$ & $-\cdot$ & $x$ & -- \\
\hline Isopoda & 1 & 1 & 1 & 1 & 1 \\
\hline Megaloptera & $\cdots$ & 3 & 3 & 3 & 3 \\
\hline Mollusca & 2 & 4 & 4 & 3 & 4 \\
\hline Nematoda ${ }^{a}$ & $\mathrm{x}$ & $\mathrm{x}$ & $\mathrm{x}$ & $x$ & $x$ \\
\hline Odonata & 5 & 5 & 5 & 7 & 5 \\
\hline Oligochaeta & $\cdots$ & 2 & 2 & 3 & 2 \\
\hline Platyhelminthes ${ }^{a}$ & -- & $\mathrm{x}$ & $\mathrm{x}$ & $\mathrm{x}$ & $\mathrm{x}$ \\
\hline Plecoptera & 4 & 7 & 6 & 5 & 6 \\
\hline Trichoptera & 7 & 8 & 8 & 9 & 8 \\
\hline Total no. of taxa & 52 & 76 & 62 & 89 & 79 \\
\hline
\end{tabular}

${ }^{a}$ Individual taxa not identified.

Source: Morton (1978), Table 3. 
Table 1-3. List of fish species collected from Grassy Creek (GCK) and lower Beax Creek (BCK) in 1974-1975 (Exxon Nuclear, Inc., 1976) and from lower Bear Creek in 1984 (TVA 1985). Quantitative sampling by electroshocking was conducted on five dates (September-A ril) in the 1974--1975 survey and one date (May) in the 1984 survey

\begin{tabular}{|c|c|c|c|c|c|c|}
\hline & \multirow{2}{*}{\multicolumn{2}{|c|}{$\frac{\text { Exxon Nuclear. }}{G C K}$}} & \multirow{2}{*}{\multicolumn{3}{|c|}{ Inc. $\frac{(1976)}{B C K}$}} & \multirow{3}{*}{$\frac{\text { TVA } \frac{(1985)}{\frac{B C K}{0.6}}}{4}$} \\
\hline & & & & & & \\
\hline & 3.5 & 1.6 & 4.3 & 1.9 & 0.8 & \\
\hline \multicolumn{7}{|l|}{ Catostomidae } \\
\hline $\begin{array}{l}\text { Catostomus commersoni } \\
\text { (White sucker) }\end{array}$ & & $\mathrm{x}$ & $\mathrm{x}$ & $\mathrm{x}$ & $x$ & $\mathrm{x}$ \\
\hline $\begin{array}{l}\text { Hypentelium nigricans } \\
\text { (Northern hog sucker) }\end{array}$ & & & & $x^{a}$ & $\mathrm{x}$ & $\mathrm{x}$ \\
\hline $\begin{array}{l}\text { Moxostoma anisurum } \\
\text { (Golden redhorse) }\end{array}$ & & & & $\mathrm{x}$ & & \\
\hline \multicolumn{7}{|l|}{ Centrarchidae } \\
\hline $\begin{array}{l}\text { Ambloplites rupestris } \\
\text { (Rock bass) }\end{array}$ & & & $\mathrm{x}$ & $x$ & $x$ & $\mathrm{x}$ \\
\hline $\begin{array}{l}\text { Lepomis auritus } \\
\text { (Redbreast sunfish) }\end{array}$ & & $x^{a}$ & & & & $\mathrm{x}$ \\
\hline $\begin{array}{l}\text { L. macrochirus } \\
\text { (Bluegill sunfish) }\end{array}$ & & $\mathrm{x}$ & $\mathrm{x}$ & & & $\mathrm{x}$ \\
\hline $\begin{array}{l}\text { L. megalotus } \\
\text { (Longear sunfish) }\end{array}$ & & $\mathrm{x}$ & & & & \\
\hline $\begin{array}{l}\text { Micropterus punctulatus } \\
\text { (Spotted bass) }\end{array}$ & & $x$ & & & & \\
\hline \multicolumn{7}{|l|}{ Clupeidae } \\
\hline $\begin{array}{l}\text { Dorosoma cepedianum } \\
\text { (Gizzard shad) }\end{array}$ & & & & & & $x$ \\
\hline \multicolumn{7}{|l|}{ Cottidae } \\
\hline $\begin{array}{l}\text { Cottus carolinae } \\
\text { (Banded sculpin) }\end{array}$ & & $\mathrm{x}$ & & $\mathrm{x}$ & $\mathrm{x}$ & $x^{b}$ \\
\hline \multicolumn{7}{|l|}{ Cyprinidae } \\
\hline $\begin{array}{l}\text { Campostoma anomalum } \\
\text { (Central stoneroller) }\end{array}$ & & $\mathrm{x}$ & $\mathrm{x}$ & $\mathrm{x}$ & $\mathrm{x}$ & $\mathrm{x}$ \\
\hline $\begin{array}{l}\text { Notropis ardens } \\
\text { (Rosefin shiner) }\end{array}$ & & & $\mathrm{x}$ & $\mathrm{x}$ & $x$ & $x$ \\
\hline $\begin{array}{l}N . \text { atherinoides } \\
\text { (Emerald shiner) }\end{array}$ & & & & & $x^{a}$ & \\
\hline $\begin{array}{l}N . \text { chrysocephalus } \\
\text { (Striped shiner) }\end{array}$ & & $\mathrm{x}$ & $\mathrm{x}$ & $x$ & $x$ & $\mathrm{x}$ \\
\hline $\begin{array}{l}\text { N. spilopterus } \\
\text { (Spotfin shiner) }\end{array}$ & & $\mathrm{x}$ & & & & \\
\hline
\end{tabular}


Table 1-3 (continued)

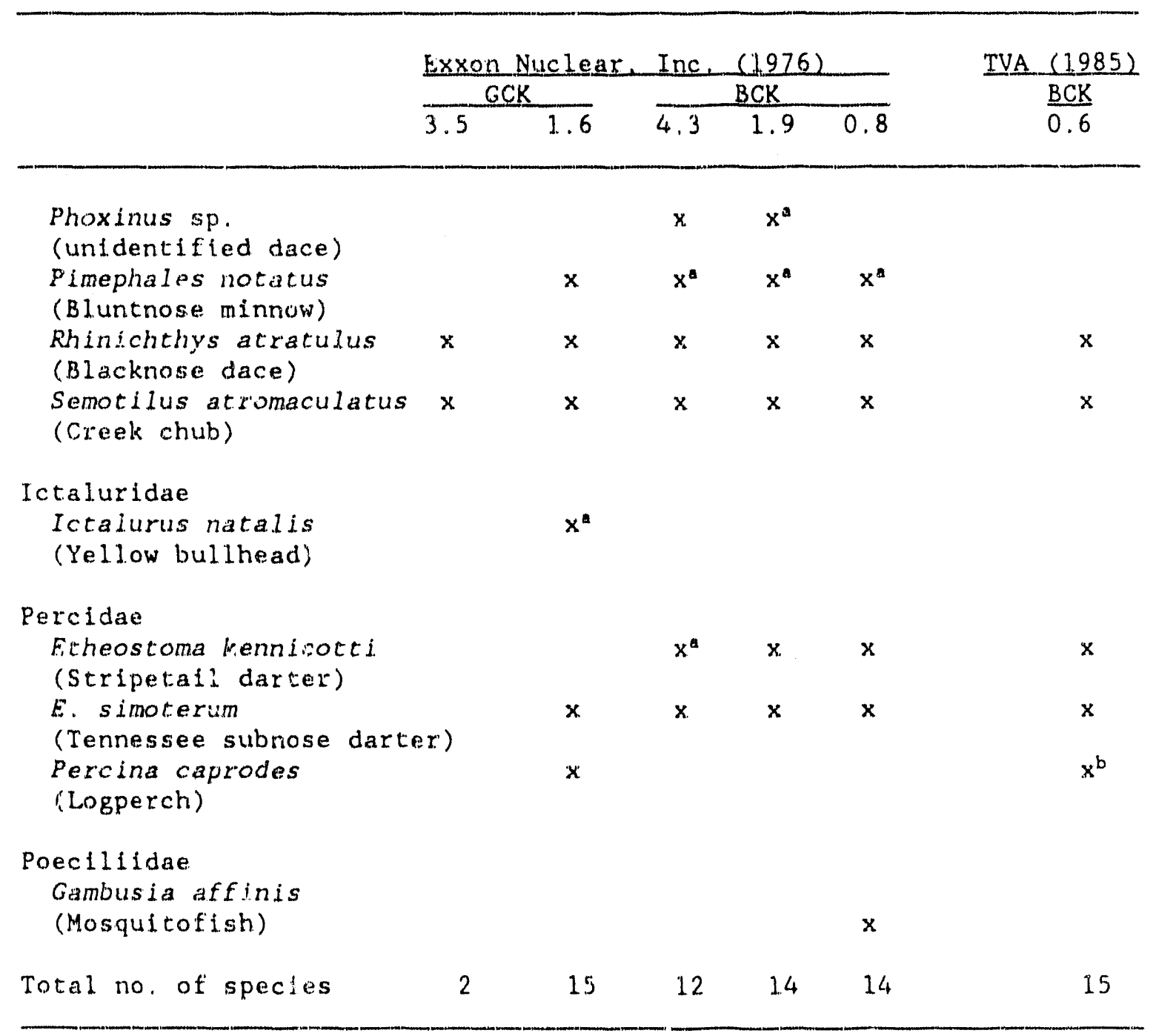

"Only one individual collected.

bot collected in quantitative sampling. 
these two species, the striped shiner (Notropis chrysocephalus), and the Tennessee dace (Phoxinus tennesseensis)--formerly the mountain redielly dace ( $P$. oreas) but reclassified recently by Starnes and Jenkins (1988)-were found in NT7 and Bear Creek below NT7. Abundance was very low above NT7 (three species and a total of six individuals in a $91-\mathrm{m}$ section with the lower end near $\mathrm{BCK}$ 10.3). The highest abunuance (on a per unit area basis) was found in NT7, which drains oil retention pond 1 in burlal ground $A$, where 35 of the 48 fish collect-d (73z) were Tennessee dace. The presence of fish in the lower reaches of NT7 was consistent with the results of bioassays conducted on the pond water, which showed no mortality to juvenile bluegill (Lepomis macrochirus) after $96 \mathrm{~h}$ (J. M. Giddings, ORNL/ESD, 1984, personal communication to J. M. Loar, ORNL/ESD).

Although direct comparisons between studies are often limited by differences in sampling locations, frequency of sampling, and methodology, these earlier blological studies, when considered together, can provide a basis for inferences regarding the nature and significance of the ecological impacts of waste disposal practices on Bear Creek watershed more than 10 years ago. This information, in turn, can provide a basis for evaluating the results of the present studies to assess the degree of ecological recovery that has occurred since the mid-1970s. Whether the impacts of waste disposal operations in Bear Creek Valley are viewed from a historical perspective or within the context of the existing environment, it is useful, at least initially, to consider upper Beax Creek, as shown in Fig. 1-1, and lowex Bear Creek (Fig. 1-2) separately.

Previous studies indicate that waste disposal operations at the Y-12 Plant have a significant adverse impact on the aquatic biota of upper Bear Creek. Although the studies also suggest that the impacts extended downstream to just below the NPDES monitoring station at $B C K 4.55$, the impacts were greatest in the upper reaches. With the headwaters of Bear Creek located near the S-3 ponds (BCK 12.87 or mile 8.0; see Fig. 1.1), the zone of greatest impact, based on results of the ERDA (1975) survey, extended downstream to at least BCK 10.8 and 
probably farther. In all likelihood, no aquatic specles, or at best very few, inhabited this reach 10 years ago.

The paucity of biota has been related to degraded water quality associated with operation of the $S-3$ ponds. The ponds were originally constructed in 1951 as evaporation/percolation basins to receive nitric acid and other nitrate wastes but have also received other solutions containing soluble metals and small amounts of organics. In 1983 they had a $\mathrm{pH}$ of 2 prior to neutralization (Jeter 1983). Measurements of Bear Creek pH taken from 1974-1975 (ERDA 1975) were consistently below 5.10 as far downstream as BCK 11.9, and in October 1974, pll values of 3.50 and 3.90 were measured at $B C K 11.1$ and $B C K 11.9$, respectively. The concentration of dissolved aluminum, measured in water passed through a $0.8-\mu \mathrm{m}$ Millipore filter, was $31.0 \mathrm{mg} / \mathrm{L}$ at $\mathrm{BCK} 11.1 \mathrm{in}$ November $(\mathrm{pH}-4.34), 7.0 \mathrm{mg} / \mathrm{L}$ in January $(\mathrm{pH}-5.09)$, and $14.0 \mathrm{mg} / \mathrm{L}$ in March $(\mathrm{pH}=4.75)($ ERDA 1975). These concentrations of aluminum and low $\mathrm{pH}$ levels would have been highly toxic to blota in Bear Creek (e.g., Driscoll et al. 1980, and Sect. 2.1).

Some improvement in water quality in upper Bear Creek apparently occurred between the periods of 1974-1975 and 1981-1982 (Table 1-4). The zone of low pH (below 5.0) no longer extended to the sanitary landfill area, and the lowest value observed at the Bear Creek Road crossing ( $B C K$ 12.0) was 5.6. This improvement may have resulted from an acid waste neutralization and recycle facility that was placed in operation at the Y-12 Plant in October 1976 (UCCND 1977). Whether ecological conditions in upper Bear Creek improved as a result of this facility can not be determined. No biological sampling was conducted in the upper reaches until the present study was initiated in May 1984. Moreover, no inferences about toxicity can be made because the data are limited. For example, the measurements taken between December and May are not necessarily indicative of water quality at other times of the year, especially during low-flow periods in the summer and early fall. Finally, although some improvement may have occurred downstream, the pH in the extreme upper reaches in the early 1980s was still low.

Then from 1983 through 1984, several actions were taken that significantly improved the water quality in this upper reach of 
Table 1-4. Mean pH (range in parentheses) of Bear Creek in three surveys conducted over the past 10 years. Hydrogen ion concentrations were used in the calculation mean pH. NS $=$ not sampled

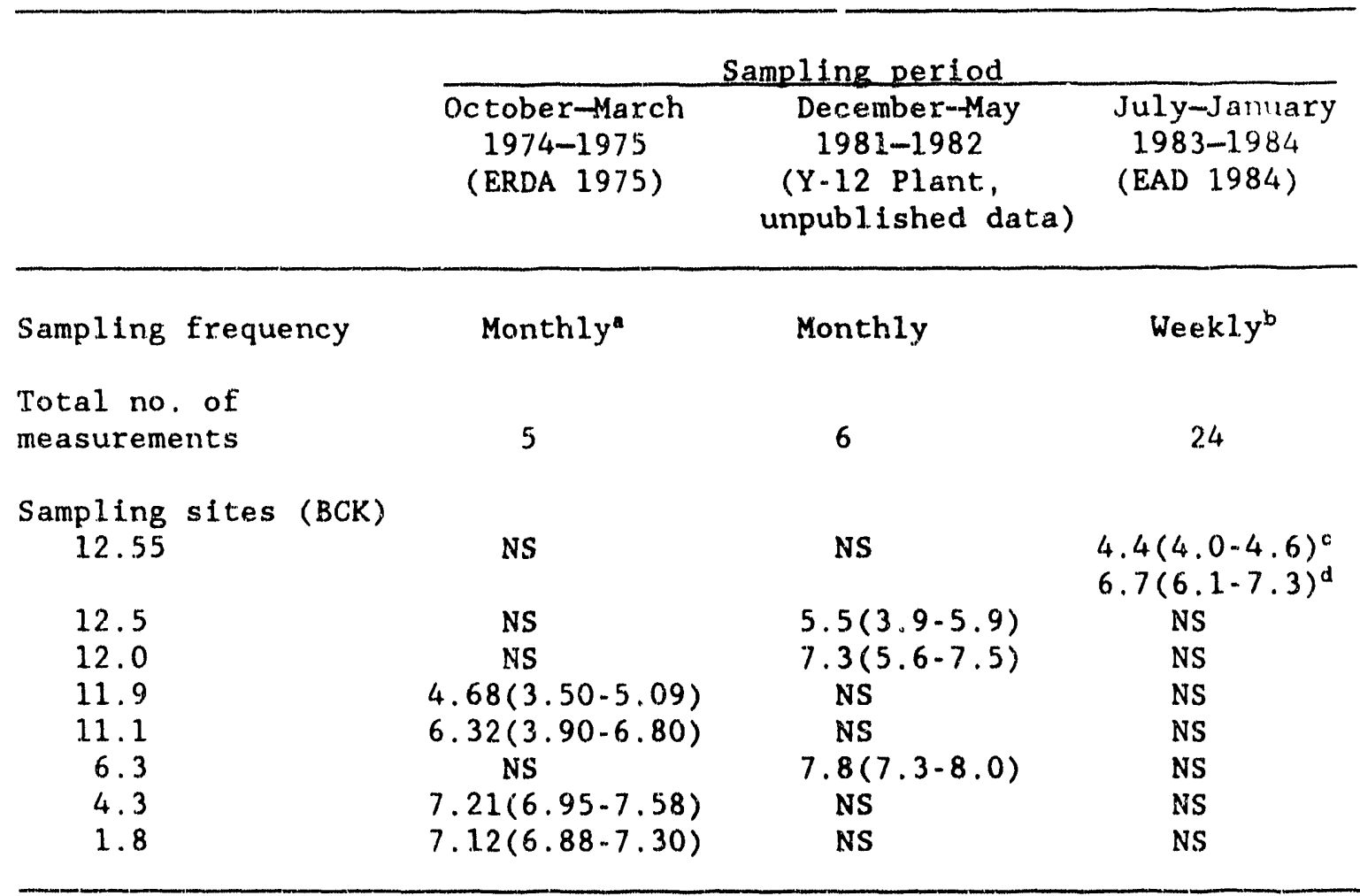

${ }^{\text {aNo }}$ samples were collected in February.

baily samples were collected Erom September 19-23, 1983; one sample was collected in November.

'Before September 29, 1983.

dAfter September 29, 1983. 
Bear Creek. Neutralization of the S-3 ponds was completed in 1983 and denitrification was completed the following year. In March 1984 all discharges to the $S-3$ ponds were terminated. These actions apparently resulted in the significant improvement in water quality that was observed in September 1983 (Table 1-4). Recent water quality monitoring data were reviewed in order to determine if existing water quality conditions could be toxic to aquatic biota in Bear Creek (see Sect. 2.1).

Previous biological surveys of lower Bear Creek indicated a diverse assemblage of benthic invertebrate and fish species, implying that significant recovery had occurred over a distance of approximately $6 \mathrm{~km}$. However, even as far downstream as $B C K$ 4.3, there was evidence that recovery was not complete. For example, a comparison of the benthic invertebrate communities at $\mathrm{BCK} 4.3$ and $\mathrm{BCK} 1.8$ revealed lower total densities and fewer species of Ephemeroptera at BCK 4.3 (Tables $1-1$ and 1-2). A comparison of the fish communities, on the other hand, provided no evidence of impact; communities at BCK 4.3, BCK 1.9, and BCK 0.8 were generally similar in species composition (Table 1-3). Moreover, the communities that existed from 1.975 through 1976 and in 1.984 near the mouth of the creek were also similar (Table 1-3).

The water quality in lower Bear Creek was substantially better than the water quality in the upper recches of the creek. For example, pH was near or above 7.0 from 1974 through 1975 (Table 1-4), and on all three sampling dates (November, January, and March) dissolved aluminum levels were less than $0.05 \mathrm{mg} / \mathrm{L}$ at both BCK 4.3 and BCK 1.8 (ERDA 1975).

Unlike upper Bear Creek, contaminant levels downstream near the Y-12 Plant NPDES monitoring station were low from 1974 through 1975, and probably remained so over the past 10 years. The mean nitrate-nitrogen concentration at the NPDES station, for example, was $11 \mathrm{mg} / \mathrm{L}$ from 1971 to 1976 prior to operation of the acid waste neutralization and recycle facility, and was also $11 \mathrm{mg} / \mathrm{L}$ for the period from 1977 to 1983 (Union Carbide Corporation annual monitoring reports for calendar years 1971-1983). Although $\mathrm{pH}$ may have increased slightly (Table 1-4), the change was probably not ecologically significant. Degraded water quality caused by elevated levels of trace elements or other contaminants was probably not responsible for the reduced density and 
diversity of benthic invertebrates at $\mathrm{BCK} 4.3$ during the period from 1974 through 1976 based on water quality and toxicity information presented in sect. 2.1. 


\section{HABITAT EVALUATION}

The Bear Creek watershed has a drainage area of $19.4 \mathrm{~km}^{2}$. Parallel northeast-trending ridges constitute the northern and southern boundaries of the watershed. Elevations in the watershed range from $230 \mathrm{~m}$ at the mouth of the creek to $372 \mathrm{~m}$ at the crest of Chestnut Ridge. The Y-12 Plant is located on the headwater divide between Bear Creek, which flows to the west of the plant, and East Fork Poplar Creek (EFPC), which flows to the east. The headwaters of Bear Creek originate in the vicinity of the $\mathrm{S}-3$ ponds; the creek flows approximately $12.9 \mathrm{~km}$ before joining EFC at kilometer 2.6.

Prior to 1940, agriculture was the dominant land use in the watershed. Aerial photographs taken in 1939 show only a narrow strip of riparian vegetation along most of Bear Creek. These agricultural lands are currently planted in pines, and the riparian vegetation today consists primarily of pines and mixed hardwoods along much of the stream. Approximately 658 of the waturshed is wooded (McMaster 1967), and much of the remainder consists of waste disposal areas located in upper Bear Creek Valley. These include the S-3 ponds, the sanitary landfill/oil landfarm area, and the burial grounds (Fig, 1-1).

Through the years, construction activities have modified the main channel of Bear Creek (R. B. Clapp, ORNL/ESD, 1989, personal communication to G. R. Southworth, ORNL/ESD). Construction of a sanitary landfill between NT5 and BCK 11.83 resulted in the relocation of the strearn channel south of its original location. Improvements to Bear Creek Road and construction of a utility corridor adjacent to Bear Creek Road required relocating the channel north of the original channel between south spring (SS) 4 and BCK 10.36. The Bear Creek channel was also modified by the construction of the NPDES monitoring station and weir at BCK 4.55 in 1970, the excavation of two lagoons near BCK 12.46 in 1972, and the installation of new culverts near BCK 9.42 in 1986. In 1988, the channel near BCK 6.89 was temporarily diverted for installation of culverts during construction of a haul road from the West Borrow area to the burial grounds, and the lagoons located near IsK 12.46 were cleaned and filled with riprap. 


\subsection{REVIEW OF RECEN' WATER QUALITY DATA}

\subsubsection{Surface Water}

Surface water in the Bear Creek watershed is affected by surface and subsurface drainage from waste burial grounds, the oil landfarm, the S-3 ponds, construction-related land disturbances, and several large springs. These sources contribute organic and inorganic chemical contaminants to Bear Creek, as well as suspended sediments and additional water and buffering capacity. In recent years, actions have been taken to reduce the input of contaminants to Bear Creek from several of these sources. The biological monitoring program and intensive monitoring of stream chemistry was initiated after many of these actions had already been taken.

\subsubsection{Organic Contaminants}

Surface waters from Bear Creek and its tributaries were analyzed during 1983 and 198, for a broad spectrum of organic priority pollutants (HSEAD 1985). Further sampling conducted in 1985 and 1986 was restricted to the main stem of Bear Creek (R. R. Turner, ORNL/ESD, 1987, personal communication to $G$. R. Southworth, ORNL/ESD). Only the volatile organic compounds (VOCs) were detected in the aqueous phase in the main stem of Bear Creek. This class of compounds consists primarily of halogenated aliphatics and low molecular weight aromatics. Trace levels of tetrachloroethene, toluene, and trichloroethene were detected at concentrations of about 10 parts per billion ( $\mathrm{ppb}$ ) each in the uppermost reaches of Bear Creek (BCK 12.36), while much higher levels of organics were detected farther downstream in the vicinity of the burial grounds and NT7. Txans 1,2-dichloroethene, tetrachloroethene, trichloroethylene, and vinyl chloride predominated, wi h traces of other halogenated aliphatics. The highest summed concentrations of vocs were detected at $B C K$ 9.91 (Table 2-1), but decreased rapidly downstream from this site, undoubtedly due to volatilization (Callahan et al. 1979).

Concentrations generally decreased to about 58 of the levels at BCK 9.91 within $0.5 \mathrm{~km}$ and were always less than $10 \mathrm{ppb}$ at BCK 7.87 (Table 2-1). Sources of the VOCs in this area are burial grounds $A-D$, which are unlain by groundwater that is highly contaminated by VOCs and drained by 
Table 2-1. Sumed concentrations $\left(\mu_{g} / L\right)$ of volatile organics in

Bear Creek surface water at varlous sites. ND - Not detected; NS = Not sampled

\begin{tabular}{|c|c|c|c|c|c|c|c|}
\hline \multirow[b]{2}{*}{ Site } & \multicolumn{7}{|c|}{ Sampling period } \\
\hline & $\begin{array}{r}\text { Sep } \\
1983\end{array}$ & $\begin{array}{r}\text { Mar } \\
1984\end{array}$ & $\begin{array}{l}\text { Aug } \\
1984\end{array}$ & $\begin{array}{r}\text { Aug } \\
1985\end{array}$ & $\begin{array}{r}\text { Jan } \\
1986\end{array}$ & $\begin{array}{r}\text { May } \\
1986\end{array}$ & $\begin{array}{r}\text { Sep } \\
1986\end{array}$ \\
\hline BCK 12.39 & NS & NS & $<10$ & $<10$ & $<10$ & $<10$ & $<10$ \\
\hline BCK 11.83 & NS & NS & $<10$ & $<10$ & 10 & $<10$ & $<10$ \\
\hline BCK 11.49 & ND & $=10$ & ND & $<10$ & $<10$ & $<10$ & NS \\
\hline BCK 11.09 & $\sin$ & ND & NS & NS & 10 & NS & $<10$ \\
\hline BCK 10.32 & NS & ND & NS & $<10$ & $<10$ & NS & $<10$ \\
\hline BCK 9.91 & 1291 & 201 & 225 & 147 & 874 & 210 & 210 \\
\hline $\mathrm{BCK} 9.43$ & 52 & 97 & 11 & 46 & 225 & 11 & 23 \\
\hline $\mathrm{BCK} 9.40$ & NS & NS & NS & 24 & 34 & $<10$ & 12 \\
\hline BCK 7.87 & NS & NS & $<10$ & $<10$ & $<10$ & $<10$ & $<10$ \\
\hline BCK 5.15 & NS & NS & NS & $<10$ & $<10$ & $<10$ & $<10$ \\
\hline BCK 3.25 & NS & NS & NS & 65 & $<10$ & $<10$ & $<10$ \\
\hline
\end{tabular}

Sources: HSEAD (1985); R. R. Turner, ORNL/ESD, 1987, personal communication to G. R. Southworth, ORNL/ESD. 
tributaries (NT7, NT8) that are contaminated with VOCs to levels 10 to 20 times those observed in Bear Creek.

The toxicities of VOCs to aquatic life are not extremely high. Toxicities 1isted by the Environmental Protection Agency (EPA 1980) indicate that acute toxicity has been observed at concentrations ranging from 5 to 118 parts per million (ppm) for these compounds. Acute toxicity was observed at 11.6 and $5.3 \mathrm{ppm}$ for dichloroethene and tetrachloroethene, respectively. Chronic effects were observed at 0.84 ppm for tetracinloroethene. Maximum concentrations of these compounds (which account for about 908 of the total VOCs in Bear Creek) are thus about a factor of four below levels known to exhibit chronic toxicity. Levels of sunmed VOCs in sections of tributaries NT7 and NT8 exceeded 2 to $3 \mathrm{ppm}$ in March and August 1984. The high levels of VOCs observed at BCK 9.91 in September 1983 and January 1986, when tributaries were not sampled, suggest that levels of VOCs in NT7 and/or NT8 may sometimes exceed the observed levels by severalfold. The observed levels in these tributaries approach those known to produce acute toxicity in sensitive species and could be chronically toxic to aquatic biota. Reduced survival and growth were observed in the toxicity tests conducted on water from NT7 in October 1984 (Sect. 3.4.1), but it is unlikely that VOCs were the cause of the toxicity. They would have been rapidly lost from the test solutions via volatilization, especially since the water sample collected on the first day of the test was used daily as replacement water during the 7 -d test period (Sect. 3.2.1).

\subsubsection{Inorganic Contaminants}

Prior to the discontinuation of use and neutralization of the S-3 ponds at the headwaters of Bear Creek, the upper reaches of the stream were acidic and highly enriched with many inorganic constituents (ERDA 1975; Turner and Kamp 1984; R. R. Turner, ORNL/ESD, 1987, personal communication to G. R. Southworth, ORNL/ESD). In 1974 and 1975, upper Bear Creek ( $B C K$ 11.1, 11.9) exhibited $\mathrm{pH}$ values ranging from 3.5 to 6.8 over a 5-month period (ERDA 1975), while from 1981 through 1983 a pH range of 3.9 to 7.5 (Table 1-4) was observed in reaches closer to the S-3 ponds (BCK 12.1, 12.5). Prior to neucralization of the $S-3$ ponds in summer 1983, the $\mathrm{pH}$ of upper Bear Creek (BCK 12.55) ranged from 4.0 to 
4.5 during July through September (EAD 1984). High levels of aluminum (more than $100 \mathrm{ppm}$ ) were noted in the acidified waters. The levels of acidity and aluminum observed prior to September 1983 are toxic to fish and sensitive aquatic invertebrates (Altshuller and Linthurst 1984) and would adversely affect the biotic community of Bear Creek. The acidity in the upper reaches of Bear Creek was neutralized farther downstream. The limited historical data show nearly neutral pH below BCK 6.3 in the samples from 1981 and 1982 and below BCK 4.3 in 1974 and 1975

(Table 1-4). Neutral conditions probably existed much further upstream in 1974 (ERDA 1975; R. R. Turner, ORNL/ESD, 1987, personal communication to G. R Southworth, ORNL/ESD). It is safe to assume that tois conditions existed in upper Bear Creek prior to neutralization of the S-3 ponds, and that this toxicity may have diminished within several kilometers downstream.

Profound changes in the chemistry of upper Bear Creek occurred following neutralization of the $\mathrm{S}-3$ ponds in 1983. Within several months, $\mathrm{pH}$ rose to more than 7.0 , total aluminum decreased from $97 \mathrm{mg} / \mathrm{L}$ to $4 \mathrm{mg} / \mathrm{L}$, and other metals also declined significantly (EAD 1984). Intensive chemical and biological monitoring of the Bear Creek ecosystem was initiated after these changes took place.

Chemical analyses of Bear Creek surface waters since the S-3 ponds were neutralized in 1983 have been conducted by Bechtel National. Inc. (HSEAD 1985), Roy F. Weston, Inc. (R. R. Turner, ORNL/ESD, 1987, personal communication to $G$. $R$. Southworth, ORNL/ESD), the Y-12 Plant (R. R. Turner, ORNL/ESD, 1987, personal communication to G. R. Southworth, ORNL/ESD), U. S. Geologic Survey (Pulliam 1985a,b), and the Oak Ridge National Laboratory (this report). These analyses reported high concentrations of dissolved inorganic salts in the upper reaches $f$ Bear Creek, typified by electrical conductivities of $2000-4000 \mu \mathrm{mho} / \mathrm{cm}$ and total dissolved solids concentrations of 2000$5000 \mathrm{mg} / \mathrm{L}$; these values are approximately 10 to 20 times higher than those values typical of reference sites. The contribution of solutes from the S-3 groundwater plume dominates the major ion inorganic chemistry of Bear Creek. The total salt content, as indexed by conductivity, closely follows the pattern expected if Bear Creek water were diluted only with uncontaminated groundwater downstream from BCK 12.4 (Table 2-2). Solute inputs and dilution vary as a result of 
Table 2-2. Dilution of upper Bear Creek solutes in Bear Creek. Tabular values are the mean $\pm S D(n-4)$, unless noted otherwise

Site Flow dilution ${ }^{a} \quad$ Conductivity dilution ${ }^{b}$

BCK 12.36

BCK 11.83

BCK 11.49

BCK 11.09

BCK 10.32

BCK 9.91

BCK 9.43

BCK 9.40

BCK 7.87
1.0

1.0

$0.58 \pm 0.28$

$0.61 \pm 0.27$

$0.21 \pm 0.01$

$(n=2)$

$0.32 \pm 0.08$

$(n=2)$

$0.43 \pm 0.33$

$(n=2)$

$0.45 \pm 0.44$

$(n-2)$

$0.28 \pm 0.28$

$(n-3)$

$0.16 \pm 0.04$

$0.15 \pm 0.09$

$0.13 \pm 0.05$

$0.15 \pm 0.09$

$0.11 \pm 0.06$

$0.12 \pm 0.10$

$0.09 \pm 0.05$

adilution factor calculated from the ratio of flow at BCK 12.36 to flow at other sites for measurements made during the week that samples were collected for chemical analyses.

bilution factor calculated from the ratio of conductivity at Bear Creek sites minus 250 to conductivity at BCK 12.36 minus 250 . Units are $\mu \mathrm{mho} / \mathrm{cm}$ and 250 is the estimated conductivity of uncontaminated groundwater infiltrating Bear Creek. Conductivity values are based on samples collected by Y-12 Plant/Roy F. Weston, Inc., for chemical analysis, 1985-1986 (R. R. Turner, ORVL/ESD, 1987, personal communication to G. R. Southworth, ORNL/ESD. 
variations in precipitation runoff and infiltration (Fig. 2-1), with the highest solute concentrations getiexily occurring during periods of low flow.

Bear Creek surface water is currently highly enriched (relative to Grassy Creek reference sites) in many inorganic ions. The downstream variation in major ion chemistry is depicted in Table 2-3. Aluminum, barium, calcium, chloride, magnesium, manganese, nitrate, potassium, sodium, sulfate, strontium, and uranium are conspicuously high in the headwaters of Bear Creek, and they decline gradually in concentration downstream. Lithium and boron are slightly elevated in the headwaters, but the highest levels occur below the burial grounds. Anmonia, beryllium, cadmium, cobalt, copper, lead, nickel, silver, and zinc are elevated in the uppermost reaches of Bear Creek, but decline to approximately background levels or below detection limits within a short distance downstream. A comparison of maximum concentrations in Bear and Grassy creeks with reported toxicity values and EPA water quality criteria for the protection of freshwater biota is presented in Table 2-4. Most of these inorganics are relatively nontoxic; many, such as calcium, magnesium, sodium, and sulfate, are typical dissolved constituents of fresh waters. The pH of Bear Creek has generally been recorded between 6 and 7 from late 1983 to the present. The high acidity noted prior to 1983 has not been observed.

Toxicity tests were conducted in March 1988 on ambient Bear. Creek water using both fathead minnow larvae and Ceriodaphnia dubia/affinis (Sect. 3.4.1). Water from the S-3 plume was obtained by sampling well GW-101, a highly contaminated well west of the S-3 pond, and tested at the same time. Analyses of metals were conducted on unfiltered water samples to determine which metal(s) might be responsible for the observed toxicity. Only a few analytes (cadmium, cobalt, manganese, and nickel) were found at higher concentrations in water causing Ceriodaphnia mortality than in nontoxic water. The concentrations of these were nevertheless low and none could be considered to be present at obviously toxic concentrations (Table 2-5). Only aluminum was present in excess of the water quality criterion; however, it exceeded the criterion in nontoxic water samples also. The diluted (5\%) GW-101 


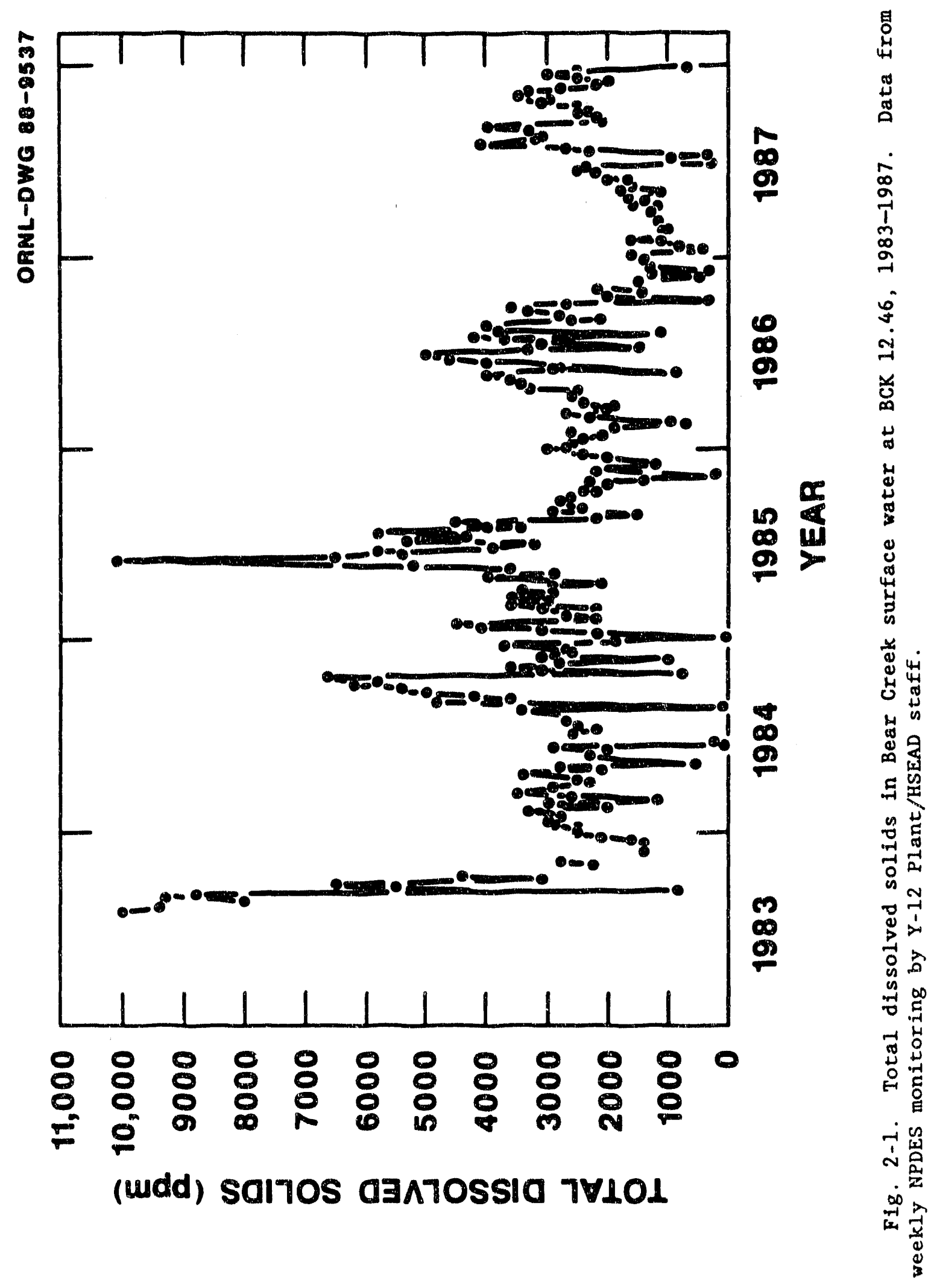




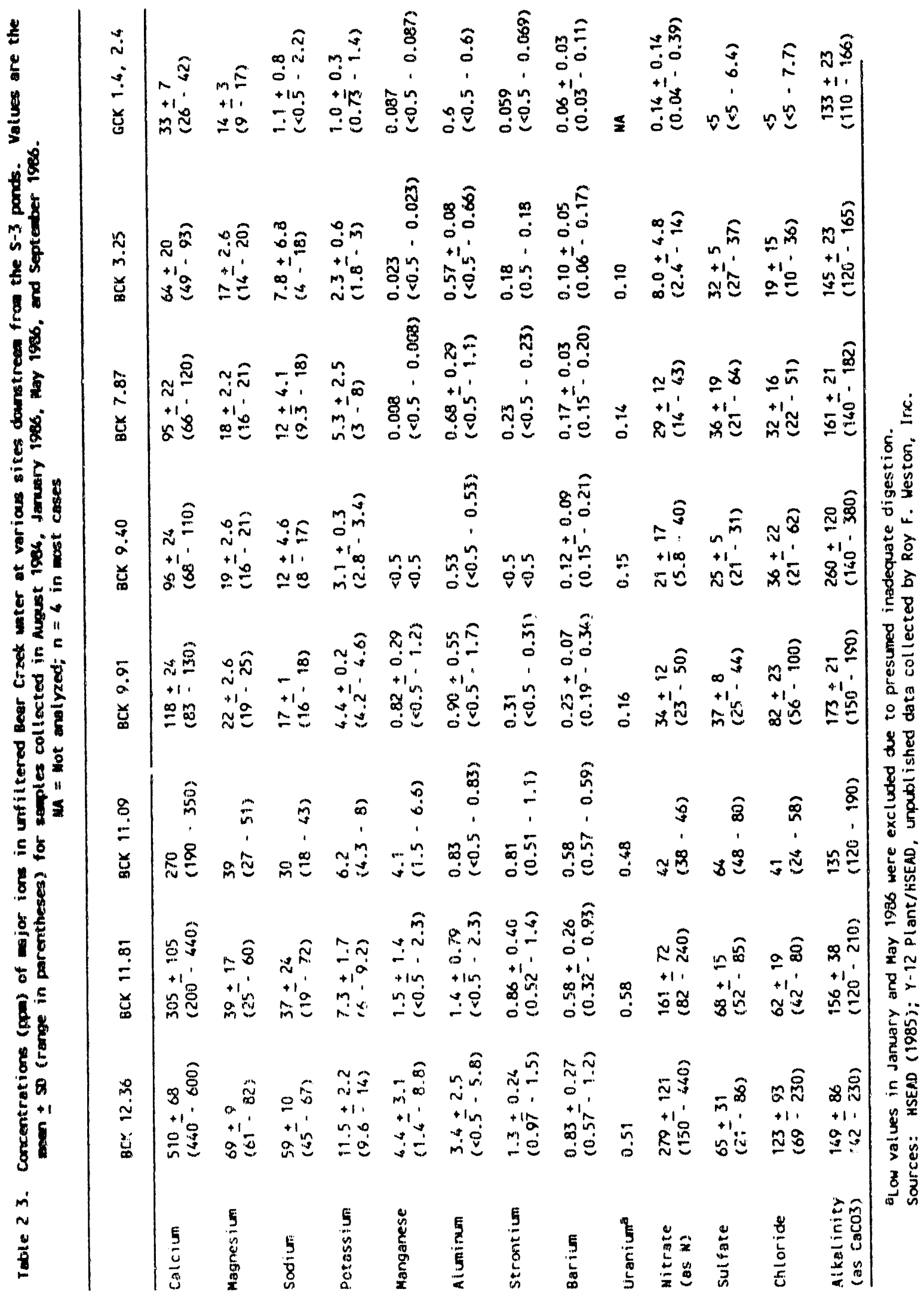


Table 2-4. Maximun concentrations, acute toxicity ranges, and water quality criteria for inorganic lons found at elevated levels in Bear Creek. Values are ppm

\begin{tabular}{|c|c|c|c|c|}
\hline & $\begin{array}{l}\text { Grassy } \\
\text { Creek }^{\mathrm{a}} \\
\text { (reference site) }\end{array}$ & $\begin{array}{l}\text { Bear } \\
\text { Creek }^{a}\end{array}$ & $\begin{array}{l}\text { Acute } \\
\text { toxicity } \\
\left(\mathrm{LC}_{50}\right)\end{array}$ & $\begin{array}{l}\text { Water } \\
\text { quality } \\
\text { criterion }\end{array}$ \\
\hline Aluminum & 0.6 & 5.8 & $0.2-38$ & 0.087 \\
\hline Ammonia & 0.04 & 0.39 & $\ldots$ & $1.47^{\mathrm{d}}$ \\
\hline Barium & 0.044 & 1.2 & $13.5-105$ & $50^{\circ}$ \\
\hline Boron & 0.01 & 1.1 & 900 & $\ldots$ \\
\hline Cadmium & 0.004 & 0.16 & $0.09-7.2$ & $0.002^{\mathrm{f}}$ \\
\hline Calcium & 42 & 600 & $\cdots$ & $\cdots$ \\
\hline Chloride & 7.4 & 230 & ... & 230 \\
\hline Copper & 0.02 & 0.04 & $0.014-1$ & $0.021^{f}$ \\
\hline Fluoride & 0.3 & 2.0 & $\cdots$ & $\ldots$ \\
\hline Lead & 0.1 & 0.4 & $1-482$ & $0.0077^{f}$ \\
\hline Lithium & 0.1 & 0.8 & $\cdots$ & $\ldots$ \\
\hline Magnesium & 17 & 82 & $\ldots$ & $\ldots$ \\
\hline Manganese ${ }^{B}$ & 0.087 & 8.8 & $1.5-1000^{B}$ & $\ldots$ \\
\hline Nickel & 0.01 & 0.08 & $1.8-188$ & $0.160^{f}$ \\
\hline Nitrate (as N) & 0.6 & 440 & $\cdots$ & $90^{\circ}$ \\
\hline Potassfum & 0.9 & 14 & $\ldots$ & $\cdots$ \\
\hline Silver & 0.03 & 0.12 & $0.02-1.0$ & $0.013^{x}$ \\
\hline Sodium & 8.2 & 72 & $\cdots$ & $\cdots$ \\
\hline Strontium & $<0.5$ & 1.5 & $86-10000$ & $\cdots$ \\
\hline Sulfate & 2 & 109 & $\cdots$ & $\cdots$ \\
\hline Uranium & 2 & 2 & $2.8-5$ & $\cdots$ \\
\hline Zinc & 0.014 & 0.022 & $0.78-14.3$ & $0.047^{f}$ \\
\hline
\end{tabular}

"Sources: HSEAD (1984a,b); Y-12 Plant/HSEAD, unpublished data from Roy F. Weston, Inc.

'Sources: Cushman et al. (1977); EPA (1986, 1988a,b); Altshuller and Linthurst (1984).

chronic criteria for the protection of freshwater aquatic life (EPA 1986).

${ }^{\mathrm{d}} \mathrm{pH}=7,25^{\circ} \mathrm{C}$.

No EPA criteria promulgated due to low toxicity. Experimental

data show listed concentration to be nontoxic.

${ }^{f}$ Calculated using a value of $200 \mathrm{mg} / \mathrm{L}$ for hardness.

$8 \mathrm{Mn}$ as permanganate, a form unlikely to occur in Bear Creek. 
Table 2-5. Concentrations of metals (ppm) in water from Bear Creek and the S-3 plume (we11 GW-101) that were associated with toxicity to Ceriodaphnia. Samples were collected on March 16, 1988, when dissolved metal concentrations in the creek were highest. Analyses by ICAP (Inductively coupled argon plasma emission spectroscopy), except where noted

\begin{tabular}{|c|c|c|c|c|c|}
\hline & \multicolumn{2}{|c|}{ Toxic concentration } & \multicolumn{3}{|c|}{ Nontoxic concentration } \\
\hline & Maximuma & Minimumb & $\begin{array}{l}\text { Maximum } \\
\text { Bear } \mathrm{Cr}\end{array}$ & $\mathrm{GW}-101^{\mathrm{d}}$ & Control ${ }^{\theta}$ \\
\hline Aluminumi, 8 & 1.1 & 0.09 & 0.14 & 0.02 & $<0.06$ \\
\hline Antimony & $<0.05$ & $<0.05$ & $<0.05$ & $<0.05$ & $<0.05$ \\
\hline Arsenic & $<0.06$ & $<0.06$ & $<0.06$ & $<0.06$ & $<0.06$ \\
\hline Barium & 0.76 & 0.28 & 0.20 & 1.0 & $<0.002$ \\
\hline Beryllium & 0.00077 & 0.00031 & 0.00036 & 0.00039 & $<0.0003$ \\
\hline Boron & $<0.08$ & $<0.08$ & $<0.08$ & $<0.08$ & $<0.08$ \\
\hline Calcium & 260 & 138 & 100 & 300 & 15 \\
\hline Cadmiums & 0.014 & 0.0035 & 0.0021 & 0.0003 & $<0.0001$ \\
\hline Chromiurn & $<0.006$ & $<0.006$ & $<0.006$ & $<0.006$ & $<0.006$ \\
\hline Cobalt & 0.0062 & 0.0024 & $<0.003$ & $<0.003$ & $<0.003$ \\
\hline Copper & $<0.01$ & $<0.01$ & $<0.01$ & $<0.01$ & $<0.01$ \\
\hline Gallium & $<0.03$ & $<0.03$ & $<0.03$ & $<0.03$ & $<0.03$ \\
\hline Iron & 0.090 & 0.036 & 0.13 & 0.048 & $<0.02$ \\
\hline Lead & $<0.05$ & $<0.05$ & $<0.05$ & $<0.05$ & $<0.05$ \\
\hline Lithium & $<0.2$ & $<0.2$ & $<0.2$ & $<0.2$ & $<0.2$ \\
\hline Magnesium & 32 & 16 & 16 & 29 & 0.4 \\
\hline Manganese & 3.4 & 0.8 & 0.45 & 0.20 & 0.006 \\
\hline Molybdenum & $<0.04$ & $<0.04$ & $<0.04$ & $<0.04$ & $<0.04$ \\
\hline Nickel & 0.074 & 0.018 & $<0.006$ & $<0.006$ & $<0.006$ \\
\hline $\begin{array}{l}\text { Nitrate } \\
\text { (as N) }\end{array}$ & 139 & 56 & 41 & 229 & 0.37 \\
\hline Potassium & 5.0 & 2.1 & 3.0 & 1.0 & $<0.1$ \\
\hline Selenium & $<0.06$ & $<0.06$ & $<0.06$ & $<0.06$ & $<0,06$ \\
\hline Silver & 0.008 & 0.003 & 0.009 & $<0.006$ & $<0.006$ \\
\hline Sodium & 13 & 5.2 & 15 & 14 & 1.4 \\
\hline Strontium & 0.67 & 0.27 & 0.30 & 1.3 & 0.05 \\
\hline
\end{tabular}


Table 2-5 (continued)

\begin{tabular}{|c|c|c|c|c|c|}
\hline & \multicolumn{2}{|c|}{ Toxic concentration } & \multicolumn{3}{|c|}{ Nontoxic concentration } \\
\hline & Maximuma & Minimumb & $\begin{array}{l}\text { Maximum } \\
\text { Bear } \mathrm{Cr}\end{array}$ & $G W-101^{d}$ & Controle \\
\hline Titanium & $<0.02$ & $<0.02$ & $<0.02$ & $<0.02$ & $<0.02$ \\
\hline Uraniumb & 0.21 & 0.08 & 0.32 & 0.0034 & 0.0006 \\
\hline Vandium & $<0.02$ & $<0.02$ & $<0.02$ & $<0.02$ & $<0.02$ \\
\hline Zinc & 0.020 & $<0.003$ & 0.015 & $<0.003$ & $<0.003$ \\
\hline
\end{tabular}

aHighest concentration was in a water sample in which Ceriodaphnia mortality was significantly higher than controls.

b Lowest concentration was in a water sample in which Ceriodaphnia mortality was significantly higher than controls. Minimum toxic concentrations were estimated by multiplying the greatest dilution associated with toxicity by the metal concentration in the undiluted water sample.

'Highest concentration was in a water sample in which Ceriodaphnia mortality was not significantly different from controls.

dS-3 plume water from well GW-101, diluted to 58. No Ceriodaphnia mortality was associated with these concentrations; however, reduced fecundity was observed at $1 / 10$ these concentrations.

'Control water was a synthetic mixture used for toxicity tests, not uncontaminated stream or groundwater.

$f_{H i g h e r}$ levels were observed on previous dates in association with turbid samples.

${ }^{8} \mathrm{Al}$ and $\mathrm{Cd}$ were analyzed by graphite furnace atomic absorption spectrophotometry; $U$ was analyzed by chemical separation and alpha spectrometry. 
sample did not contain any of these metals at concentrations exceeding those in nontoxic Bear Creek water, but barium, calcium, magnesium, strontium and nitrate were higher in the well sample than in nontoxic water from Bear Creek. Thus, while the toxicity of Bear Creek and S-3 plume water was evident, it was not possible to associate toxicity with any specific substance.

Aluminum concentrations in uppermost Bear Creek exceeded $4 \mathrm{ppm}$ on numerous occasions in 1983 and 1984 following neutralization of the S-3 ponds (EAD 1984; R. R. Turner, ORNL/ESD, 1987, personal communication to G. R. Southworth, ORNL/ESD). These levels exceed the solubility of aluminum at $\mathrm{pH} 6$ to 7 (Burrows 1977). Precipitates rich in $\mathrm{Al}(\mathrm{OH})_{3}$ coat the strear bottom in the upper reaches of Bear Creek. Aluminum concentrations in natural waters at $\mathrm{pH} 7$ comnonly exceed the levels predicted by mineral equilibria, due to the formation of micro-colloids (Altshuller and Linthurst 1984). Groundwater in the vicinity of upper Bear Creek contains more than 10 ppm "dissolved" aluminum (R. R. Turner, ORNL/ESD, 1987, personal communication to G. R. Southworth, ORNL/ESD; HSEAD 1985). Thus, it appears as though groundwater containing high concentrations of aluminum is leaching into the upper reaches of Bear. Creek, where the $\mathrm{pH}$ rises and aluminum hydroxide polymerizes and precipitates.

Because the EPA criterion for chronic exposure of $87 \mathrm{ppb}$ is exceeded even in the reference stream (Grassy Creek), the toxicity of aluminum in uppermost Bear Creek is difficult to evaluate. In addition, most studies have focused on the toxicity of aluminum in acidic waters, where it is highly toxic. Although measured concentrations of aluminum may be high at $\mathrm{pH} 6$ to 7 , much of it may be present as relatively inert particles. However, a study in which rainbow trout were exposed for $45 \mathrm{~d}$ to $5.2 \mathrm{ppm}$ of aluminum at $\mathrm{pH} 7$ (conditions under which most of the aluminum was present as suspended particulates) resulted in high mortality and reduced growth (Burrows 1977). Exposure conditions in that study approximate conditions in the uppermost reaches of Bear Creek, suggesting that aluminum may be toxic to stream biota.

The relatively high concentrations of aluminum measured in Grassy Creek (approximately $0.5 \mathrm{ppm}$ ) indicate that suspended clay 
minerals may also be contributing to the observed aluminum concentrations in Bear Creek and Grassy Creek. Daily aluminum measurements of Bear Creek water for one week following a storm in March 1988 suggested a positive correlation between high levels of suspended solids and measured aluminum concentrations. The highest aluminum concentrations observed in Bear Creek subsequent to neutralization of the S-3 ponds occurred in August 1984. Concentrations decreased from $5.8 \mathrm{ppm}$ at BCK 12.36 to $1.2 \mathrm{ppm}$ at BCK 11.59 . Concentrations remained about $1 \mathrm{ppm}$ downstream to BCK 5.15. While not a precipitous decrease in concentration, the combination of dilution and conversion of aluminum to less toxic aluninum hydroxide polymers and aggregates would have reduced any toxicity present in the uppermost reaches.

Few pertinent toxicity data were found for manganese. Cited values in Table 2-4 refer to permanganate, a form not likely to be found in natural waters. Manganese is generally viewed as having low toxicity in aquatic systems (Altshuller and Linthurst 1984).

Potentially, the most toxic constituents of Bear Creek surface waters are cadmium, copper, lead, nickel, silver, and zinc. These substances are elevated in upper Bear Creek sediments and are found at levels close to detection lilusts in surface water. They presumably enter the stream in contaminated groundwater but are sequestered by sediments and flocculated aluminum hydroxide upon dilution with stream water. As shown in Table 2-4, aluminum, cadmium, copper, lead, and silver were found in upper Bear Creek at concentrations approaching the EPA water quality criteria for the protection of aquatic life. The toxicity of these metals varies widely, depending on species of organism and water chemistry (Table 2-4), and it is likely that the observed concentrations in Bear Creek are nontoxic to the biota inhabiting it. on the other hand, these levels are similar enough to those producing toxicity to be possible causes of the toxicity found in Bear Creek bioassays. The rapid downstream decrease in aqueous concentrations of these metals coincides with decreased toxicity seen in bioassays. However, the possible presence of suspended aluminum hydroxide, a highly effective sorbent for cations such as cadmium and copper, could refute 
this explanation. If the elevated levels of toxic cations are sequestered by colloids, the cations would be far less toxic.

Uranium levels are elevated in Bear Creek, but the concentration is less than $2 \mathrm{ppm}$ at all sites. Uranium exhibits acute toxicity at approximately $3 \mathrm{ppm}$ in very soft water but is far less toxic $\left(\mathrm{LC}_{50}\right.$ $-140 \mathrm{ppm}$ ) in hard waters, such as Bear Creek. Concentrations of uranium found to be toxic in Ceriodaphnia and fathead minnow bioassays conducted in the ESD Aquatic Toxicology Laboratory ranged from about 0.5 to $3.0 \mathrm{ppm}$ in moderately hard water (A. J. Stewart, ORNL/ESD, 1987, personal communication to G. R. Southworth, ORNL/ESD).

The large spring at BCK 9.41, SS5, is contaminated with the same inorganic constituents as Bear Creek. Concentrations of metals and arions are about 15 to $30 \%$ of the levels found in uppermost Bear Creek, with the exception of sediment-accumulating metals, such as cadmium, copper, nickel, lead, silver, and zinc. These metals were all below detection limits in the spring water. Water from sS5 was nontoxic in bioassays (Sect. 3.2). The reduction in toxicity in comparison with upper Bear Creek water could be because toxic metal ions are removed during subsurface transport or simply a result of dilution with additional groundwater.

Chemical analyses again prove inadequate to assess the toxicity of Bear Creek water. Depending upon the toxicity criteria that are utilized, the water in Bear Creek can be estimated to be either safe for aquatic life or toxic. The bioassays and instream faunal surveys provide a much better indication of the toxicity of Bear Creek water and can be used to measure improvement.

\subsubsection{Sediments}

\subsubsection{Organic Contaminants}

Bear Creek sediments contain low levels of VOCs, ofl residues, and polychlorinated biphenyls (PCBs). The distribution of VOCs at the sediment sampling sites closely parallels their distribution in water samples with the highest levels occurring near the burial grounds. The maximum concentration of $1932 \mathrm{ppb}$ summed VOCs was found in a tributary of Bear Creek, NT7, that drains oil retention pond 1 in burial ground A. 
The concentrations of VOCs were highly variable among sampling dates, but the highest levels in Bear Creek on a given date always occurred at BCK 9.91, just downstream from NT7. The maximum concentration observed in sediments from this site was 650 ppb summed VoCs. Only barely detectable traces of VOCs were found in sediments farther downstream.

The predominant compounds found in the sediments at BCK 9.91. were trans 1,2-dichloroethene, tetrachloroethene, and trichloroethene. These same compounds predominated in water samples at this site. These low molecular weight halogenated hydrocarbons have relatively low affinities for sorption to sediments (Callahan et al. 1979). Measured concentrations in sediments roughly approximated aqueous concentrations at the same site. Thus, sediment levels of VOCs suggest the existence of a facile steady state between VOCs in contaminated ground, surface water, and sediments rather than an accumulation of contaminants in the solid phase that acts as a continuing source of contamination to surface water. The toxicity of sediments due to VOCs should therefore not exceed that of the overlying water, which was discussed previously.

Traces of methylene chloride and 1,1,1-trichloroethane were detected in the sediments of the uppermost reaches of Bear Creek near the S-3 ponds. These compounds are not major constituents of surface waters further downstream, indicating that a somewhat different suite of VOCs may contaminate groundwater near the $5-3$ ponds. Levels are low enough (approximately $10 \mathrm{ppb}$ ) to be of little ecological concern.

The gravimetric measure of oil and grease in sediments of Bear Creek (only on 1983 and 1984 samples) indicated substantial contamination at some sites (more than $200 \mathrm{ppm}$ ) and little or no contamination at others. A reference site on Grassy Creek (GCK 2.4) had the highest value of any main stem site. If these high values for oil and grease truly reflect anthropogenic contamination, then the sediments should have shown substantial contamination by polycyclic aromatic hydrocarbons (PAHs) and high molecular weight aliphatic hydrocarbons. However, only occasional samples showed even low levels of phenanthrene, pyrene, and fluoranthene (generally less than $2 \mathrm{ppm}$ ). Similar results were observed for aliphatics. Although these data indicate low-level contamination of Bear Creek sediments with anthropogenic oils, the 
levels are not at all consistent with the gravimetric ofl and grease measure. The gravimetric measure is probably an analytical artifact and should not be assumed to be oil and grease because more sophisticated chemical analyses did not detect typical constituents of oil and grease. The low levels of PAHs and aliphatics in some sediments are probably of ittle ecological significance.

Significant concentrations of PCBs were found in Bear Creek sediments between BCK 9.91 and BCK 7.87 (Fig. 2-2). Although contamination was highest at BCK 9.91, where PCBs averaged $1.7 \mathrm{ppm}$ and ranged from 0.39 to $4.2 \mathrm{ppm}$, contamination was also evident in three tributaries (NT6, NT7, and NT8) that drain the burial grounds

(S. E. Herbes, ORNL/ESD, 1988, personal communication to

G. R. Southworth, ORNL/ESD). Of the three streams, PCB levels were highest in NT7, which appears to have the greatest impact on PCB levels in Bear Creek sediments. Sediments in the downstream reaches of the creek contained lower concentrations of PCBs, averaging about $0.2 \mathrm{ppm}$; traces of PCBs were also found in sediments from most sites upstream from NT6.

The concentrations of PCBs in Bear Creek sediments are comparable to levels found in systems where concentrations in fish exceed $1 \mathrm{ppm}$. PCB contamination in fish from Bear Creek was evident in 1982 (W. Van Winkle, ORNL/ESD, 1982, personal communication to G. R. Southworth, ORNL/ESD), when rock bass (Ambloplites rupestris) collected from the lower reaches of the stream were found to contain $0.65 \pm 0.29 \mathrm{ppm}$ wet wt total PCBs (mean \pm standard deviation). Five years later, fish were again collected from lower Bear Creek to evaluate the relative importance of the EFPC discharge at New Hope Pond as a source of PCBs to lower Poplar Creek and the Clinch River (Rogers et al. 1988). In 1987, PCBs in rock bass averaged $0.28 \pm 0.12 \mathrm{ppin}(\mathrm{n}=8)$, a level comparable to that found in sunfish in the lower third of EFPC and well above the level typically found in fish from uncontaminated sites $(0.02 \pm 0.01 \mathrm{ppm})$. As part of the same study, Asiatic clams (Corbicula fluminea) that were suspended in cages in Bear Creek (BCK 4.55) for $30 \mathrm{~d}$ accumulated $1.01 \mathrm{ppm}$ PCBs (vs $0.05 \mathrm{ppm}$ in controls), indicating that Bear Creek contained a source of biologically available PCBs. Whether sediments are an important source or merely a co-indicator of PCB contamination in Bear Creek is not known. 
ORNR-DWG 90.6449

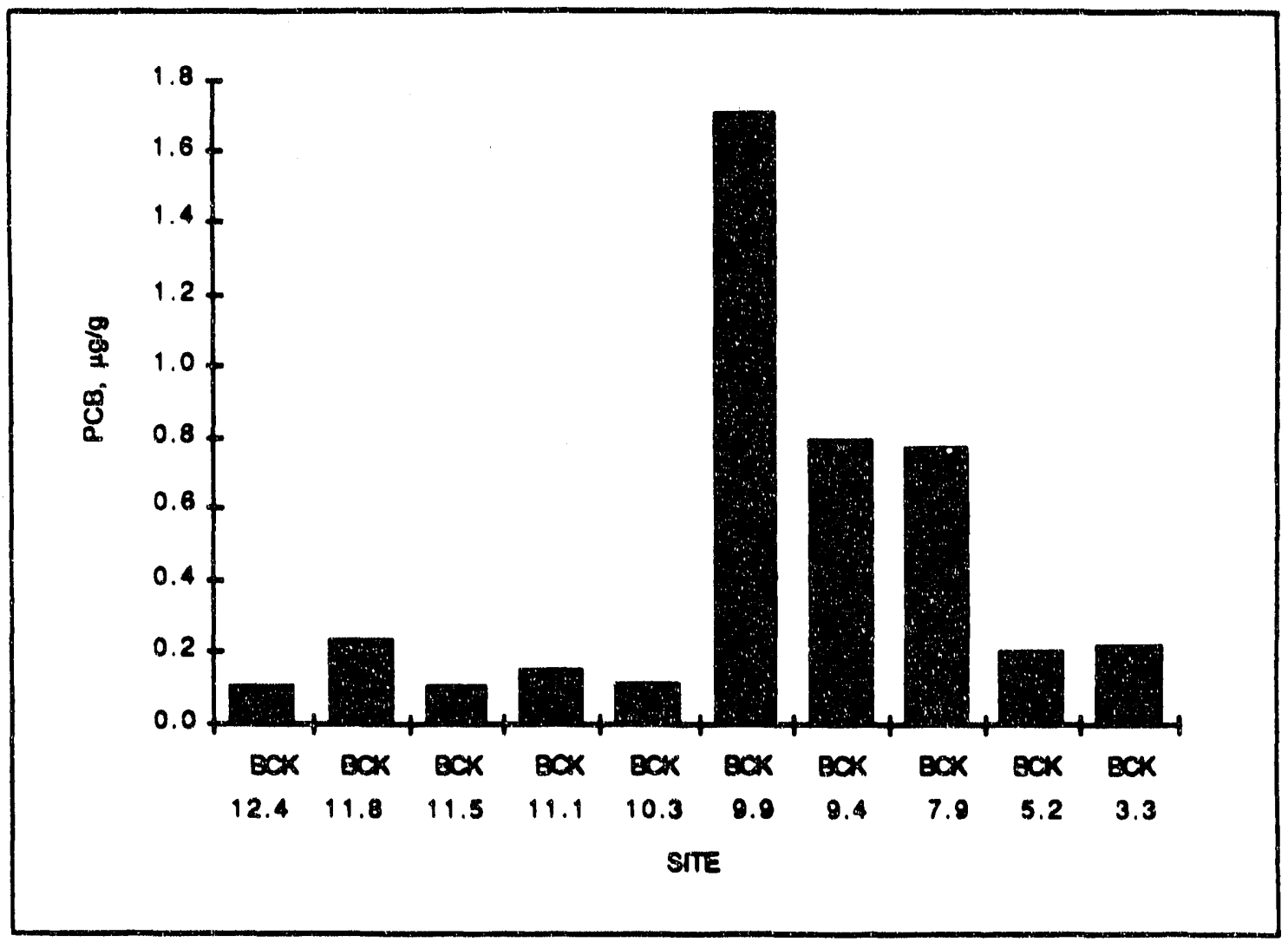

Fig. 2-2. Average mean concentrations of PCBs in fine surface sediments ( $\mu \mathrm{g} / \mathrm{g}$ dry $w t$ ) at varlous sites in Bear Creek, showing input of PCBs from tributaries (NT7 and NTB) draining the burlal grounds near BCK 10.3 and BCK 9.9. Data from Roy Weston, Inc., sampling in 1986. (R. R. Turner, ORNL/ESD, 1987, personal communication to G. R. Southworth, ORNL/ESD). 
Subsequent measurements of PCBs in rock bass at this site in 1988 and 1989 (Kornegay et al. 1990, 1991) averaged $0.19 \pm 0.14$ and $0.14 \pm$ $0.05 \mathrm{ppm}(\mathrm{n}-8)$, respectively. The decrease in PCB concentrations between 1987 and 1989 is probably a result of remedial actions carried out during this period that reduced PCB inputs to NT7 and Bear Creek from oil-contaminated seeps and the oil retention ponds.

\subsubsection{Inorganic Contaminants}

The concentrations of many metals in upper Bear Creek sediments are high and generally comparable to sediments from polluted sites (Prater and Hoke 1980). However, many metals are also elevated in Grassy Creek sediments, suggesting that the natural composition of the sediments is high in metals, perhaps due to the high clay content. Comparison of Bear Creek with Grassy Creek indicates several metals that are clearly elevated in Bear Creek sediments: cadmium, copper, lithium, nickel, uranium, and zinc. Sediment concentrations of these metals are highest in the upper reaches of the stream and decrease near the mouth to levels that are similar to those in Grassy Creek (Table 2-6). With the exception of lithium, all of these metals are adsorbed to a high degree by clay minerals and organic coatings (Callahan et al. 1979); thus, high levels in clay sediments could be toxicologically inert. The presence of higher-than-expected lithium levels in these sediments suggests that this may be the case. Because lithium is far less susceptible to ion-exchange sorption than copper, cadmium, nickel, or zinc, its presence indicates that these sediments have a high capacity to sequester cations.

It is not possible to evaluate the toxicity of Bear Creek sediments based on chemical analysis alone, since the availability of the metal contarninants is not known. Ambient water quality criteria for copper and cadmium, the most important sediment contaminants, are very low (EPA 1986). Assuming a hardness of $200 \mathrm{mg} / \mathrm{L}$ as $\mathrm{CaCO}_{3}$ for Bear Creek, the criteria for protection of aquatic life from chronic exposure to dissolved cadmium and copper are 2.0 and $21 \mathrm{ppb}$, respectively. Cadmium concentrations in interstitial water could approach this criterion, 


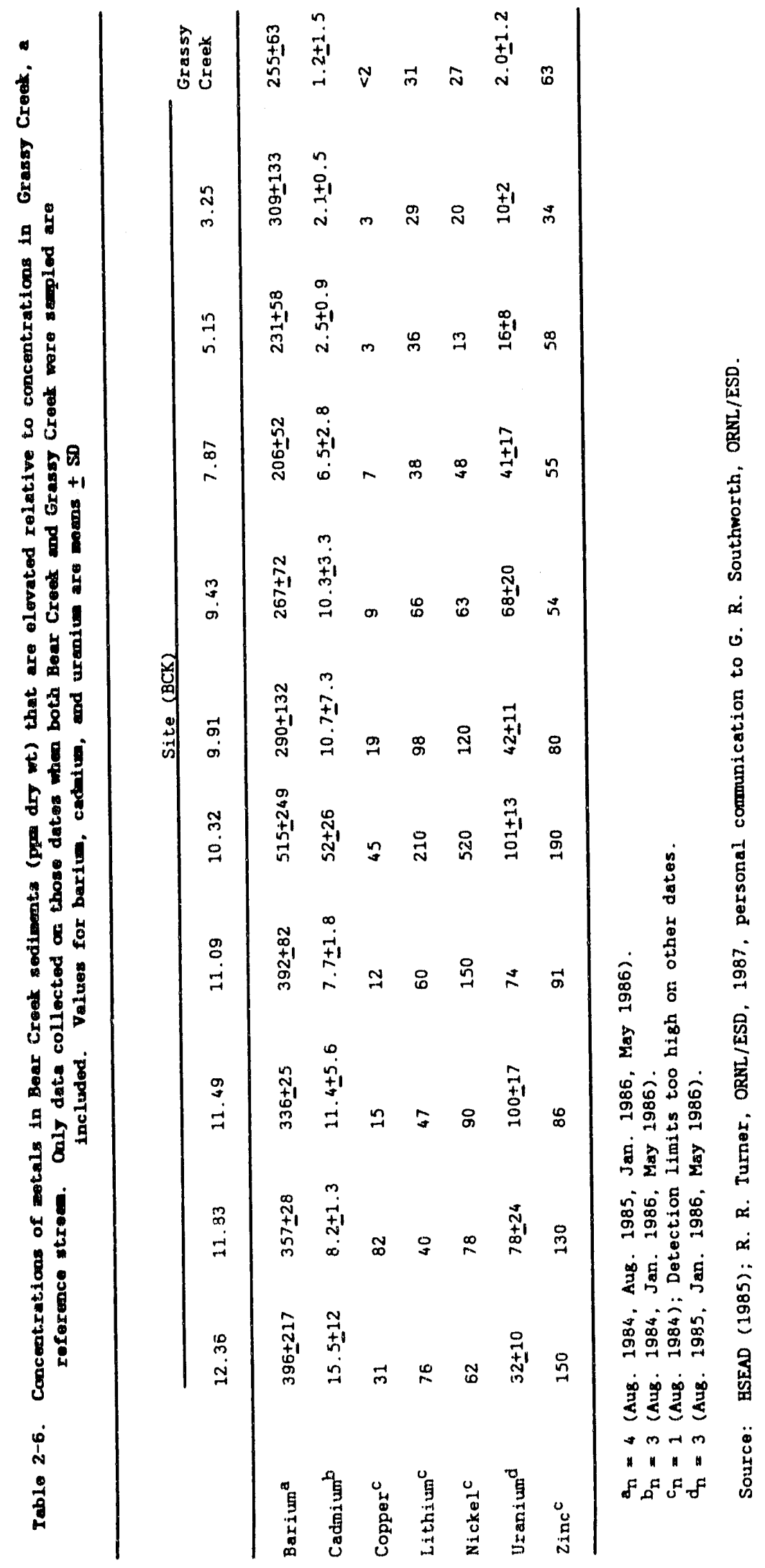


despite its very high affinity for clay solls (assuming $K_{d}-10^{4}-10^{5}$ ). Copper may also approach $21 \mathrm{ppb}$ in interstitial waters at sediment concentrations of about $25 \mathrm{ppm}$ (assuming $K_{d}-10^{3}-10^{4}$ ), which are typical of upper Bear Creek. Also, water hardness in upper Bear Creek typically exceeds the $200 \mathrm{ppm}$ value used in calculating water quality criteria. Thus, although $200 \mathrm{ppm}$ was conservatively used to determine criteria in order to avoid estimates based on excessive extrapolation, it is likely that the values obtained overestimate the toxicity of metals in the upper reaches of Bear Creek. Concentrations of copper and cadmium needed to produce toxicity in most bioassays exceed $0.5 \mathrm{ppm}$ (Cushman et a1. 1977). Thus, it is possible that Bear Creek sediments do not exhibit toxicity to biota even if interstitial copper and cadmium concentrations exceed EPA water quality criteria.

Water quality criteria for nickel and zinc at a hardness of $200 \mathrm{mg} / \mathrm{L}$ as $\mathrm{CaCO}_{3}$ are $160 \mathrm{ppb}$ and $47 \mathrm{ppb}$, respectively. Assuming $K_{d}=10^{3}-10^{4}$ for these metals, interstitial concentrations are likely to be less than or equal to water quality criteria. Similarly, if $K_{d}=$ $10^{2}-10^{3}$ for uranium, aqueous concentrations are unlikely to exceed toxic levels. Calcium, magnestum, and manganese were high in a few sediment. samples, suggesting the accumulation of precipitated $\mathrm{CaCO}_{3}$ at locations where groundwater high in dissolved limestone enters the stream. Mercury does not appear to be a major contaminant in the sediments of Bear Creek. Concentrations are far below those found in New Hope Pond sediments (20 ppm maximum in Bear. Creek compared with more than $100 \mathrm{ppm}$ in New Hope Pond), but range up to 100 times the levels found in uncontaminated sediments. Fish from lower Bear Creek contained elevated levels of mercury (0.2 to $0.5 \mathrm{ppm}$ ) in 1982 (Van Winkle et al. 1984); in 1984 (TVA 1985); and in 1987 and 1988 (Rogers et al. 1989, Kornegay et a1. 1990). While well below the Food and Drug Administration action level of $1 \mathrm{ppm}$, these data do indicate the presence of biologically available mercury in the Bear Creek system. 


\subsection{FLOW AND THERMAL CHARACTERISTICS}

\subsubsection{Geohydrology}

Bear Creek Valley is located in the Valley and Ridge physiographic province and is underlain by Cambrian limestones, shales, and siltstones of the Conasauga Group. The Maynardyllle limestone in the upper part of this group contains numerous solution cavities. The most numerous and largest (vertically) cavities were encountered in drill holes near and adjacent to Bear Creek (J. M. Loar, ORNL/ESD, 1987, personal communication to G. R. Southworth, ORNL/ESD). Bear Creek Valley is bounded to the north by Pine Ridge, which is composed of sandy shales and sandstones of the Rome Formation, and to the south by Chestnut Ridge, which is underlain by siliceous dolomite of the Knox Group. The Knox Dolomite is the major aquifer in the Oak Ridge area, and the shales and sandstones of the Rome Formation are among the poorest water-bearing formations (McMaster 1967). Most of the shale formations in the Valley and Ridge Province may yield some water in seep areas but generally do not support springs of significant size (Sun et al. 1963).

The hydrology of Bear Creek and its tributaries reflects the underlying geology of the watershed. The main stem of Bear Creek above the U.S. Geological Survey (USGS) gauging station at BCK 4.55 is characterized by reaches of stream where flow is lost to the solutioncavity system (J. M. Loar, ORNL/ESD, 1987, personal communication to G. R. Southworth, ORNL/ESD). A major losing reach is located between the burial grounds and oil landfarm near BCK 10.41, and another is located just above BCK 4.70. Periods of zero flow are common in Bear Creek near BCK 10.41 but occur less frequently at BCK 4.70 (Table 2-7). The north tributaries of Bear Creek above SS5, especially NT3, NT4, NT5, and NT6 (Fig. 1-1), drain portions of Pine Ridge; these streams are intermittent and usually dry during summer and early fall. The south tributaries, on the other hand, originate as springs in the Knox Dolomite of Chestnut Ridge and are perennial streams. There is evidence that springs recelve at least some flow from the solution-cavity system, although the precise outlets of the system are unknown (J. M. Loar, ORNL/ESD, 1987, personal communication to G. R. Southworth, ORNL/ESD). 
Table 2-7. Frequency and duration of zero-flow perlods in Bear Creek, 1984-1987. NS = not sampled

\begin{tabular}{|c|c|c|c|c|c|c|c|c|}
\hline \multirow[b]{2}{*}{ Site } & \multicolumn{4}{|c|}{$\begin{array}{l}\text { Proportion of sampling } \\
\text { dates with zero flow } \\
\end{array}$} & \multicolumn{4}{|c|}{$\begin{array}{c}\text { No. of consecutive } \\
\text { sampling dates of zero flow }\end{array}$} \\
\hline & 1984 & 1985 & 1986 & $1987^{b}$ & 1984 & 1985 & 1986 & $1987^{b}$ \\
\hline BCK 12.46 & $0^{c}$ & 0 & 0 & 0 & 0 & 0 & 0 & 0 \\
\hline BCK 11.64 & 0 & 0 & 0 & 4 & 0 & 0 & 0 & 1 \\
\hline $\mathrm{BCK} 11.17$ & 17 & 0 & 19 & 36 & 3 & 0 & 5 & 6 \\
\hline $\operatorname{BCK} 10.41$ & 54 & 38 & 77 & 68 & 7 & 2 & $6^{d}$ & 14 \\
\hline BCK 9.53 & 8 & 0 & 15 & 44 & 2 & 0 & 1 & 9 \\
\hline BCK 9.41 & 0 & 0 & 0 & 0 & 0 & 0 & 0 & 0 \\
\hline BCK 7.87 & $0^{c}$ & 0 & 0 & 0 & 0 & 0 & 0 & 0 \\
\hline BCK 4.70 & NS & 0 & 15 & 28 & NS & 0 & 3 & 6 \\
\hline
\end{tabular}

May-october only; $n=24$ (1984), $\mathrm{n}=26$ (1985), $\mathrm{n}=27$ (1986), and $\mathrm{n}=25$ (1987).

${ }^{b}$ Actual values may be higher because no measurements were taken during October 17-31 when precipitation was low (total for that month was only 248 of normal).

${ }^{c}$ No flow measurements were taken prior to July $26,1984$.

djuly 17-August 22 and again from September 5-October 9. 


\subsubsection{Surface Water Hydrology}

The characterization of surface water hydrology in Bear Creek watershed is based on weekly or continuous flow measurements at 10 main stem stations and 15 tributaries. Continuous USGS records of stream flow are available at BCK 4.55 (the NPDES station on lower Bear Creek) since March 1985 and at BCK 6.24 and BCK 3.88 since September and October 1986, respectively. The USGS has also monitored flows on two north tributaries (NT14 and NT15) and an east tributary (ET1) since October 1986 (Fig. 1-2). Measurements of stream flow were conducted weekly between March 19, 1984, and October 16, 1987, by ORNL/ESD staff at 19 sites, all but 3 of which were located in the Bear Creek watershed at or above SS5. Since November 1987, monitoring has been conducted monthly. The flow-measuring techniques utilized in the ESD program are described by R. B. Clapp, ORNL/ESD, 1988, personal communication to G. R. Southworth, ORNL/ESD.

Flow data collected on Bear Creek and selected tributaries from 1985 through 1987 by both USGS and ESD personnel are summarized in Table 2-8. Because the ESD program was primarily a hydrologic characterization of Bear Creek during low-flow periods, the increase in the mean annual discharge observed from 1985 to 1987 at a:1 main stem sites except BCK 12.46 is probably spurious. High flows could not be accurately measured and peak flows could have been missed by the weekly sampling frequency. Moreover, the maximum flow measured at the ESD site BCK 4.70 was only 408 of that observed at the USGS site BCK 4.55 in 1986 and 1987 and less than 108 of that observed in 1985. Although two large springs (SS7 and SS8) enter Bear Creek between these two sites, their contribution to the flow at $B C K 4.55$ would not significantly increase the annual maximum flow. The decrease in the annual minimun flow observed between 1985 and 1987 kis most likely real, reflecting the effects of an extended drought.

\subsubsection{Drought Effects}

The ecological evaluation of Bear Creek described in this report coincided with a period of extended drought, which is described below in terms of its effect on both precipitation patterns and stream flows. 


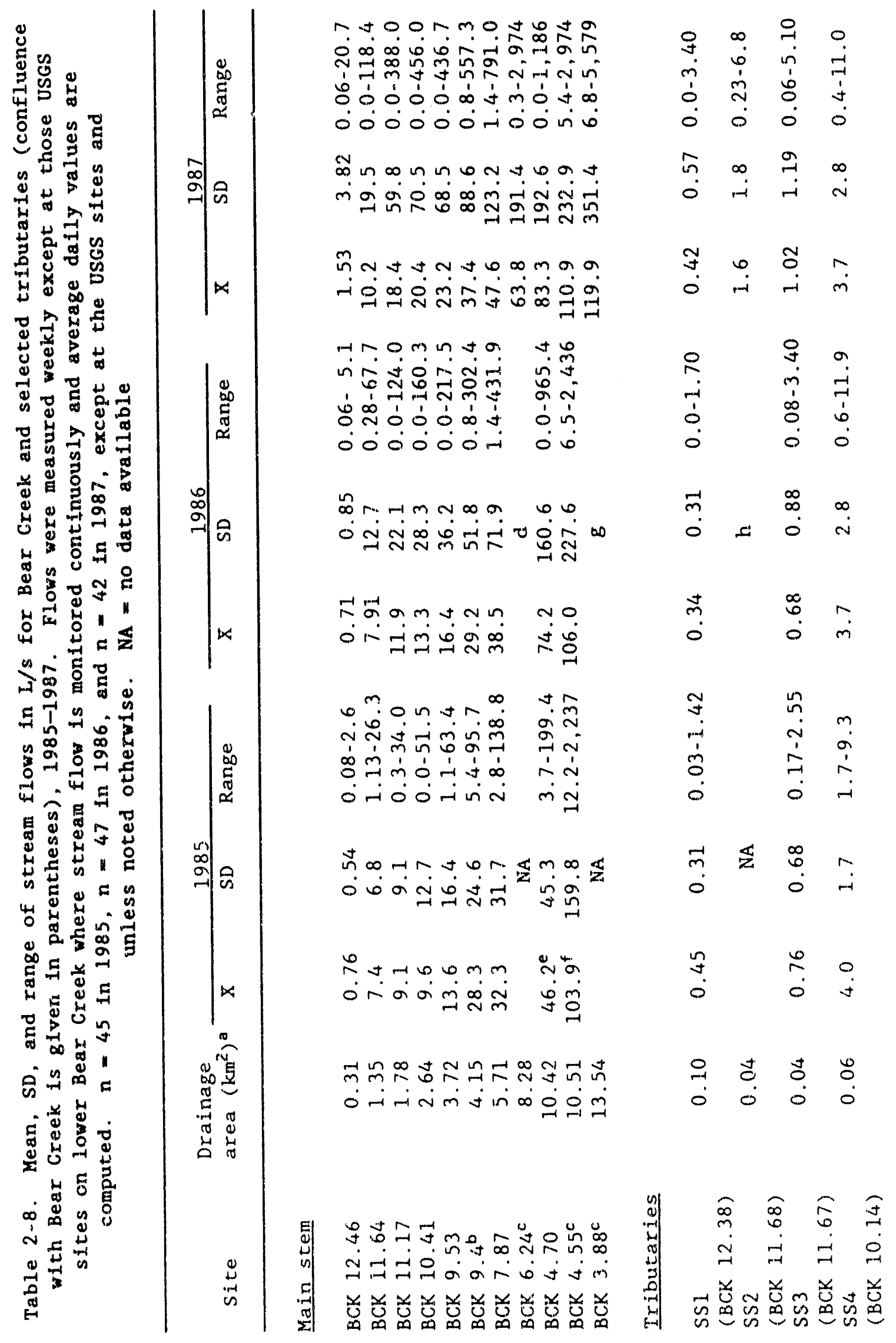




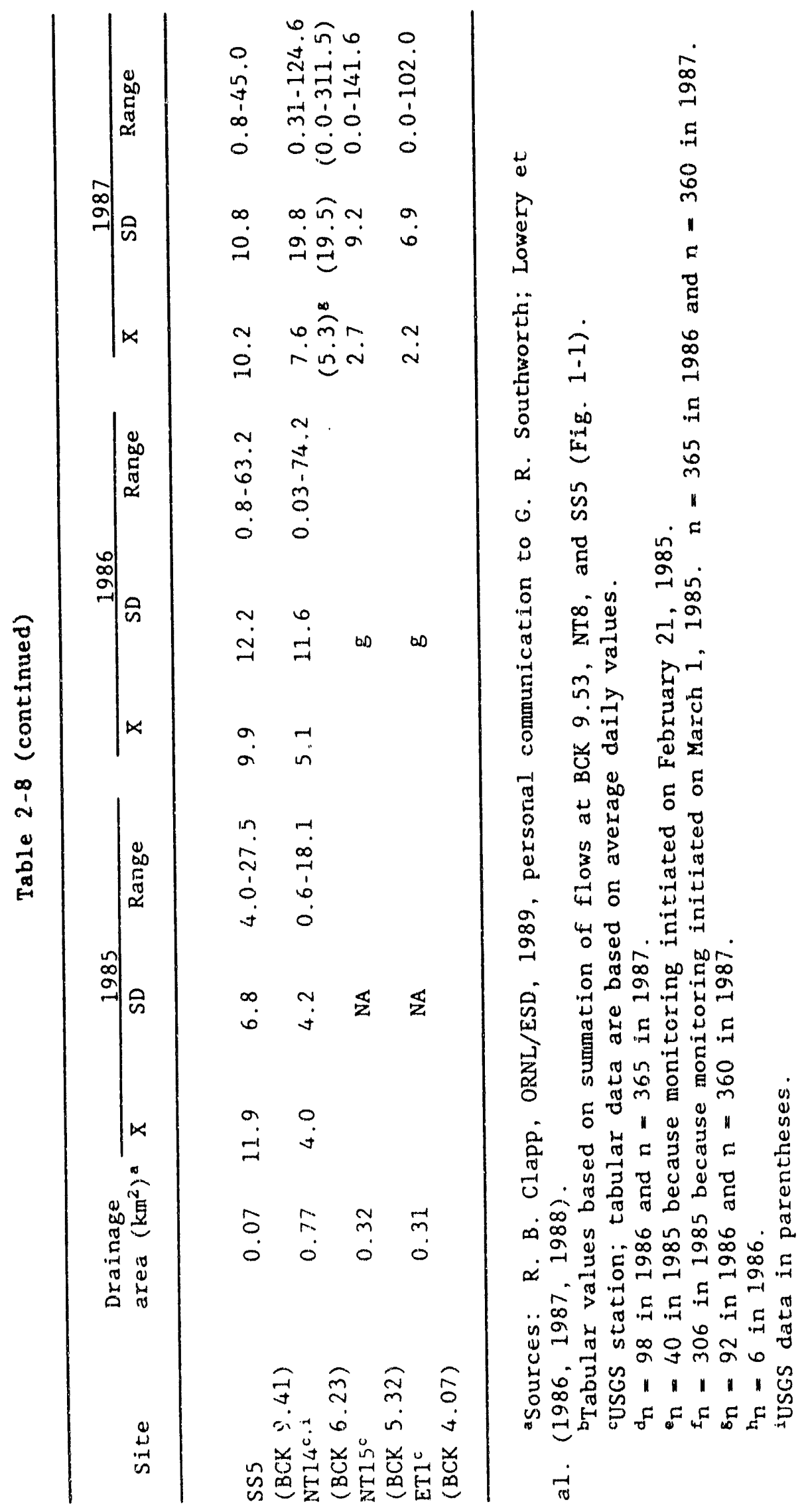




\section{Precipitation Patterns}

Precipitation is measured by the National Oceanic and Atmospheric Administration (NOAA) at the Atmospheric Turbulence and Diffusion Laboratory (ATDL) in Oak Ridge. Records are available since 1973 for this site and since May 1947 for previous locations in Oak Ridge. Precipitation is also monitored by ESD staff at seven sites on the Oak Ridge Reservation (ORR), including a site in the Bear Creek burial grounds where precipitation has been measured since August 1984. The site is located between NT5 and NT6 and approximately $150 \mathrm{~m}$ north of Bear Creek near BCK 10.6 (Fig. 1-1). The ATDL is approximately $5.6 \mathrm{~km}$ northeast of the Bear Creek site.

Annual precipitation at the ATDL site was below the mean for the 1951-1980 period of record in four of the five years between 1983 and 1987. It was less than 758 of the mean in 1986 and 1987 (Table 2-9) and was at or above the mean in only three months of each year (Fig. 2-3). of particular significance was the below normal rainfall that occurred from November through April in each year from 1984 through 1.987 (Table 2-9). During these months, evapotranspiration is typically minimal and the groundwater recharge rate is usually high. Low precipitation, however, can result in low recharge of the aquifer, thus resulting in lower-than-normal stream flows. The effect on flow from consecutive years of low groundwater recharge can be cumulative.

Rainfall during the other six months of the year (May through October) was above the 30-year mean in 1984 and 1985 but was only 768 and 798 of the mean in 1986 and 1987, respectively (Table 2-9). As much as 80 \% of the precipitation that falls during July to September is lost to evapotranspiration (McMaster 1967), so stream flow is usually low because of low runoff. At this time, streams axe at base flow, and the proportion of surface flow contributed by groundwater is maximum. The annual minimum flow decreased from 1985 to 1987 at most sites in the Bear Creek watershed (Table 2-8), and the occurrence of zero flow increased in both frequency and area over this same period (Fig. 2-4 and Table 2-7). Annual precipitation measured at the rain gauge near BCK 10.6 decreased by 11.18 from 1986 to 1987, whereas precipitation at the ATDL meteorological station in Oak Ridge increased by 3.88 over this 
Table 2-9. Comparison of precipitation $(\mathrm{mm})$ for two periods of the year with contrasting evapotxanspiration rates and groundwater recharge rates, 1983-1988. Data were recorded at the NOAA meteorological station in Oak Ridge. Mean (= normal) precipitation is based on the 1951-1980 record period

\begin{tabular}{|c|c|c|c|c|c|c|}
\hline & \multicolumn{2}{|c|}{ Annual } & \multicolumn{2}{|c|}{ November-Apri] } & \multicolumn{2}{|c|}{ May-October } \\
\hline & Total & $\begin{array}{c}8 \text { of } \\
\text { normal }\end{array}$ & Total & $\begin{array}{c}8 \text { of } \\
\text { normal }\end{array}$ & Total & $\begin{array}{c}8 \text { of } \\
\text { normal }\end{array}$ \\
\hline 1983 & 1210.8 & 87.0 & 765.3 & 98.4 & 502.2 & 81.9 \\
\hline 1984 & 1435.6 & 103.2 & 719.1 & 92.4 & 864.9 & 141.0 \\
\hline 1985 & $1181.6^{b}$ & 85.0 & 466.4 & 60.0 & 723.4 & 118.0 \\
\hline 1986 & $986.3^{b}$ & 70.9 & 440.4 & 56.6 & 484.6 & 79.0 \\
\hline 1987 & $1023.9^{b}$ & 73.6 & 642.9 & 82.7 & 469.2 & 76.5 \\
\hline 1988 & 1243.3 & 89.4 & 549.4 & 70.6 & 527.6 & 86.0 \\
\hline Mean & 1390.9 & & 777.7 & & 613.2 & \\
\hline
\end{tabular}

afrom November of preceding year to April of year listed.

${ }^{b}$ Total annual precipitation recorded at a rain gauge in the Bear Creek Valley burial grounds was $1,030.15 \mathrm{~mm}$ in 1985 (excluding January 1-17); $1,002.71 \mathrm{~mm}$ in 1986; and $890.94 \mathrm{~mm}$ in 1987 . The gauge was installed in August 1984 and is located approximately $150 \mathrm{~m}$ north of Bear Creek near BCK 10.6 (Fig. 1-1).

Source: NOAA (1988). 

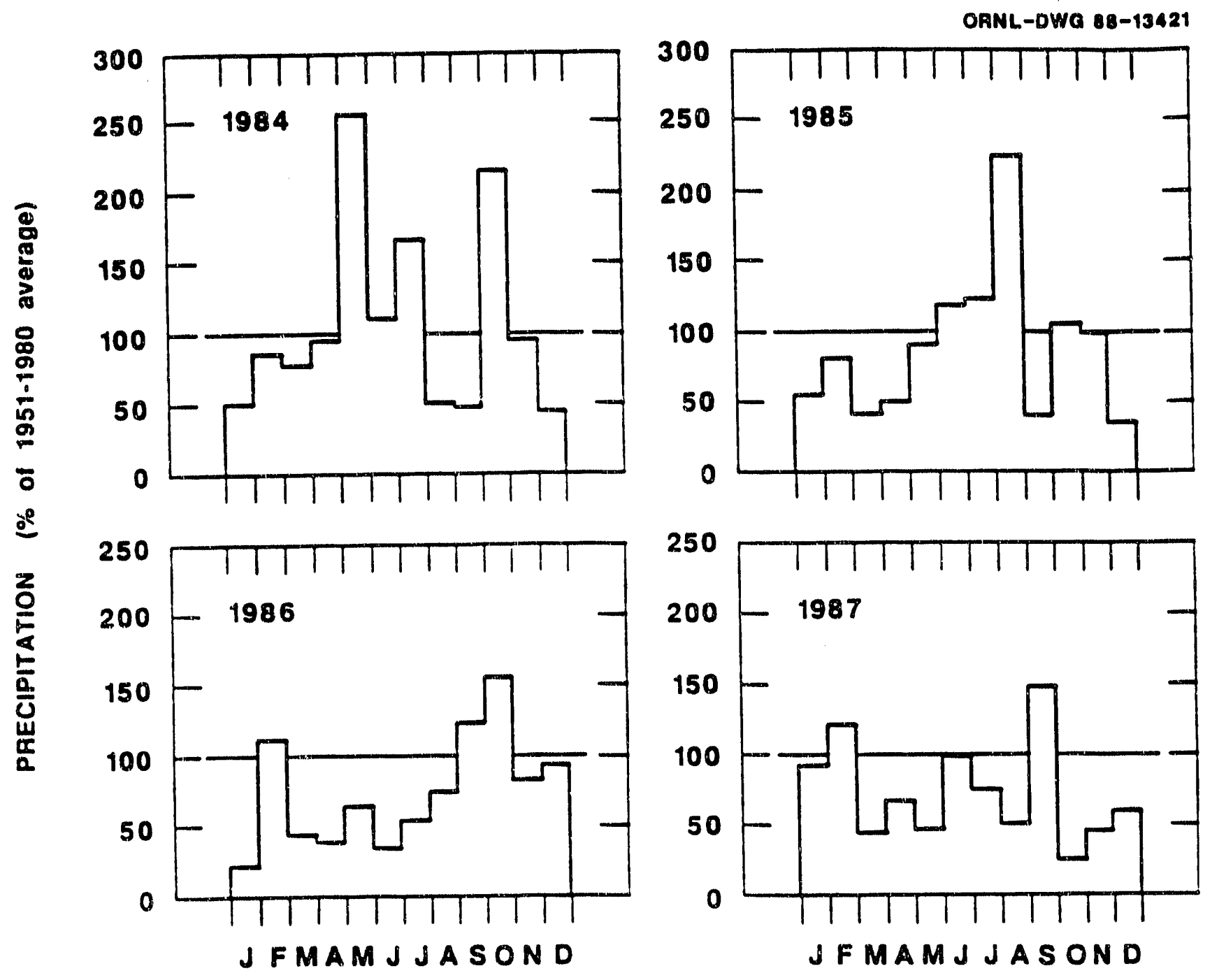

Fig. 2-3. Monthly precipitation, as percent of average (1951-1980 record period), at the NOAA meteorological station in Oak Ridge, 1984-1987. The station is located approximately $3.5 \mathrm{~km}$ noxtheast of the headwaters of Bear Creek. Source: NOAA (1988). 


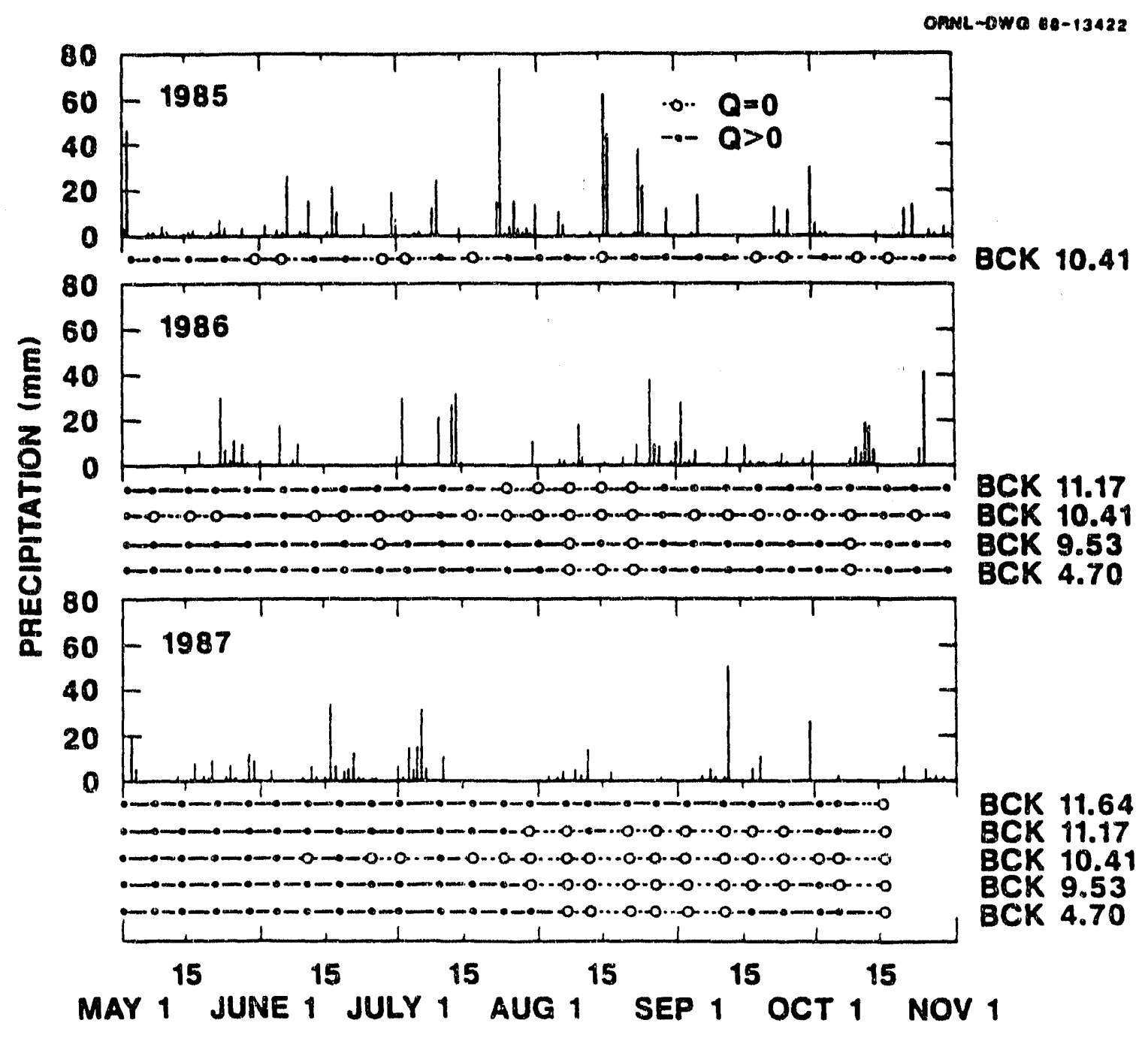

Fig. 2-4. Comparison of total daily precipitation and the frequency of occurrence of zero flow in Bear Creek, 1985-1987. Sampling dates are indicated by open circles (zero flow) and closed circles (flow $>0.02 \mathrm{~L} / \mathrm{s}$ ). Precipitation was measured at a rain gage located near BCK 10.6 in the Bear Creek burial grounds. Total precipitation for the perlod May through October is given in Table 2-9, footnote $b$. 
same period. The trend toward increasing severity of the drought through time was due to both low rainfall in late summer and fall and to the cumulative effect of low groundwater recharge rates from 1984 through 1986. The effects of the drought on stream flow in Bear Creek are discussed in greater detail below.

\section{Bear Creek Hydrograph}

The 3-year hydrograph for lower Bear Creek at the NPDES monitoring station ( $B C K$ 4.55) was dominated by extensive periods of low flow in 1986 and 1987 (Fig. 2-5). In both years, the mean annual flow at BCK 4.55 (Table 2-8) was approximately 508 of that estimated by McMaster (1967) for the period 1936-1960. From late July through October of the two years, mean daily flow was consistently below $10 \mathrm{~L} / \mathrm{s}$ and contrasted sharply with 1985 when stream flow never fell below $10 \mathrm{~L} / \mathrm{s}$ (Fig. 2-5). Minimum flows were always more than double the $7 \mathrm{Q} 10$ of $2.8 \mathrm{~L} / \mathrm{s}$ (i.e., the lowest mean discharge for seven consecutive days with a recurrence interval of 10 years) but, in 1986 and 1987, minimum flows were less than the estimated $7 Q 2$ of $8.5 \mathrm{~L} / \mathrm{s}$ for this site (McMaster 1967).

Because of below-normal precipitation, especially during the period from November to April (Fig. 2-3), the Bear Creek hydrograph exhibits infrequent periods of high flow. There were eight major storms (i.e., greater than $5 \mathrm{~cm}$ of precipitation in a $24 \mathrm{~h}$ period) from 1985 through 1987, but only one had a recurrence interval greater than 1.5 years. The maximum 24-h rainfall during this period occurred on August 16-17, 1985, when $10.9 \mathrm{~cm}$ of rain was recorded at the ATDL station in Oak Ridge (NOAA 1985, 1986, 1987, 1988). A storm of this magnitude has a recurrence interval of three years (Sheppard 1974). Runoff from the August 1985 storm resulted in a peak flow in Bear Creek that was similar in magnitude to those observed in the winter and early spring, when runoff is usually high due to minimal evapotranspiration. This peak in flow was more than an order of magnitude greater than the peak flows that occurred during the summer and fall of 1986 and 1987 (Fig, 2-5). 


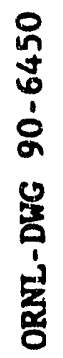
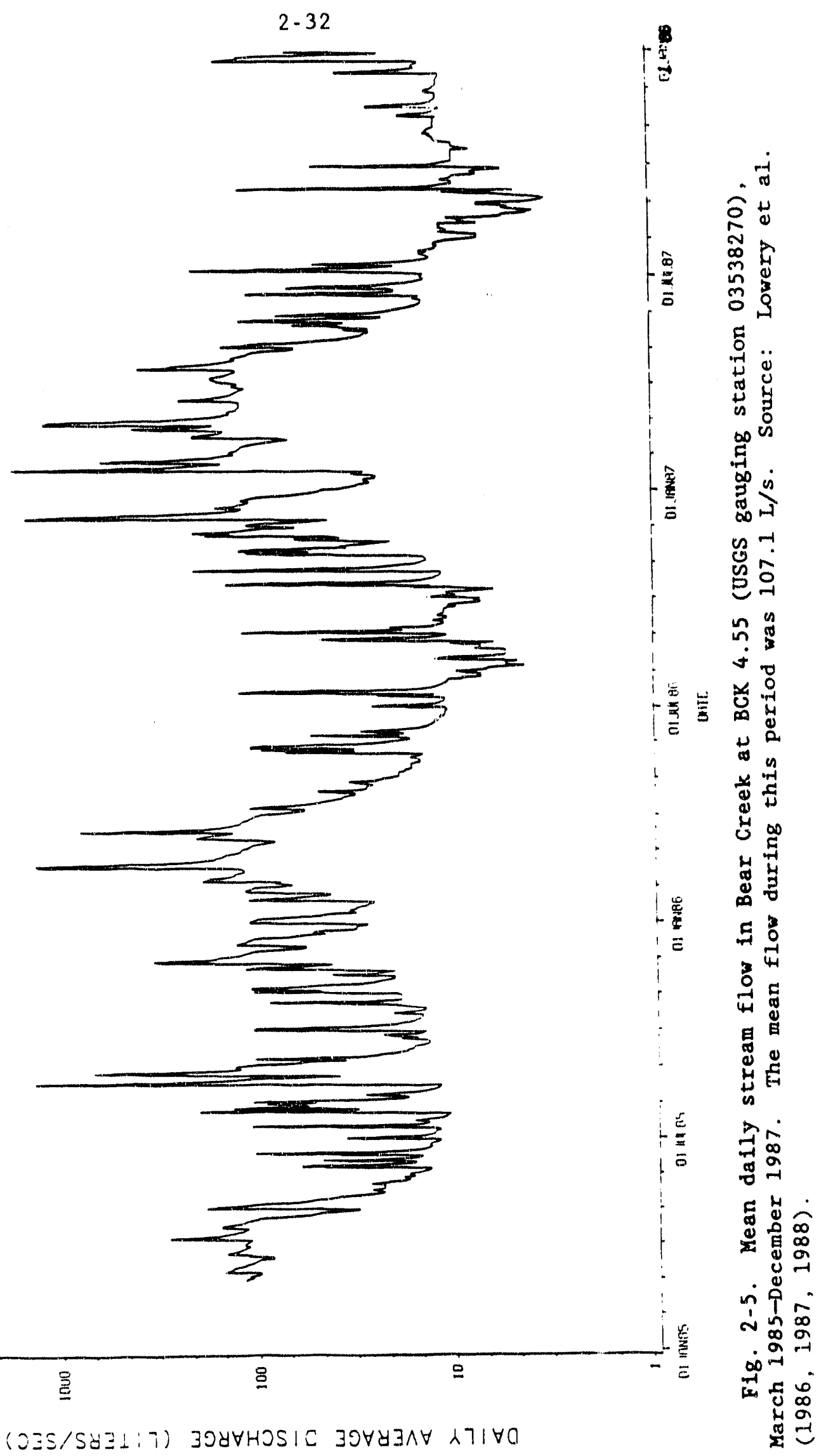


\subsubsection{Importance of Spxings}

The numerous springs that originate on the north slope of Chestnut Ridge are a dominant feature of the Bear Creek hydrograph, especiaily during drought periods. At such times, most of the flow in the main stem of Bear Creek is contributed by springs. The best example of the importance of these springs occurred in fall 1987, a time of low precipitation (e.g., rainfall was 248 and 478 of the 30 -year mean in October and November, respectively; see Fig. 2-3) that followed a period of extended drought (Sect.2.2.2.1). Four of the five flow-monitoring stations on Bear Creek above SS5 were dry (Table 2-7 and Fig. 2-4). The only flow in this reach of stream during this period was immediately below SS2, SS3, and SS4 and in the headwaters (BCK 12.46) below the S-3 ponds.

The springs in upper Bear Creek differ greatly in flow rate (Table 2-8). Flow rates are highest in SS5 at BCK 9.41 and lowest in SS1 at BCK 12.38 where flow was intermittent between late August and mid-October 1987. Several springs also occur downstream of SS5, and two of the largest (SS7 and SS8) are located less than $100 \mathrm{~m}$ above the USGS/NPDES monitoring station at BCK 4.55. Although flow at this site was never zero (Table 2-8 and Fig. 2-5), a section of stream at BCK 4.70 immediately above SS7 and SS8 was periodically dry in both 1986 and 1987 (Fig. 2-4). Thus, springs in this limited section of Bear Creek, like those in the $3 \mathrm{-km}$ reach above 555 , provide a significant portion of the flow in Bear Creek during periods of low rainfall.

\subsubsection{Thermal Characteristics}

Continuous monitoring of water temperatures was initiated in September 1985 at SS5 and three sites in Bear Creek located just above, immediately below, and $1.54 \mathrm{~km}$ below the spring. In April 1987, two additional sites (BCK 11.98 and Grassy Creek, a reference stream) were added to the monitoring program. The temperature data are summarized in Appendix A for 1985, 1986, and 1.987 (Tables A-1, A-2, and A-3, respectively).

In addition to their importance in stabilizing flows, springs also influence the thermal regime of Bear Creek, especially the upper reaches 
where springs are numerous and flows are intermittent in summer and early fall. The thermal characteristics at a given site are dependent, in part, upon the proximity of springs. Mean temperatures at BCK 9.40 just below SS5 were approximately 2 to $3^{\circ} \mathrm{C}$ warmer in the winter and 4 to $8^{\circ} \mathrm{C}$ cooler in the summer compared to BCK 9.91 above the spring (Fig. 2-6). The temperature differential between the two sites was greater in the summer than winter because of the seasonal difference in flow and the smaller effect of the spring on mainstem flows in winter. Although BCK 9.91 is located less than $250 \mathrm{~m}$ below $S \$ 4$, the flow rate of this spring is only one-third that of SS5 (Table 2-8). The thermal regime at $B C K 9.91$ is nearly identical to that at $B C K 7.87$ located approximately $1.5 \mathrm{~km}$ below SS5 (Fig. 2-6). These comparisons indicate that the moderating effect of springs on water temperatures in Bear Creek is highly localized.

The effect of springs on temperature extremes, however, was more pronounced and extended over greater distances. The maximum temperature at $B C K 9.91$ was $24.9^{\circ} \mathrm{C}$, which was similar to that at BCK $9.40\left(23.4^{\circ} \mathrm{C}\right)$ but $6.7^{\circ} \mathrm{C}$ below the maximum observed at BCK 7.87 (Table A-3). Temperatures as high as $38^{\circ} \mathrm{C}$ were recorded at $\mathrm{BCK} 11.98$ during a period of near-zero flow in July and August 1987 (Table A-3). This site is not significantly influenced by springs; the nearest upstream spring is SS1, which was dry in late August 1987. Minimum winter temperatures were higher at BCK 9.91 than BCK 7.87 (Tables A-1, A-2, and A-3) and, 1ike the trend in maximum temperatures, indicate a greater moderating effect on temperature at $\mathrm{BCK} 9.91$, the site nearest a spring.

Springs have their greatest influence on stream temperatures during periods of low rainfall in summer and fall. Both the mean and maximum temperature in August 1987 exceeded those in June and July at BCK 9.91 and BCK 7.87. At BCK 9.40, however, August temperatures were actually lower than those observed in the two previous months (Table A-3). Rainfall for August 1987 totaled only $3.2 \mathrm{~cm}$ in the Bear Creek burial grounds ( $51 \%$ of normal at the Oak Ridge site), and no precipitation occurred on 22 consecutive days prior to August 2. Thus, the importance of springs in moderating the effects of elevated stream temperatures 
ORNL-DWG 90-6451
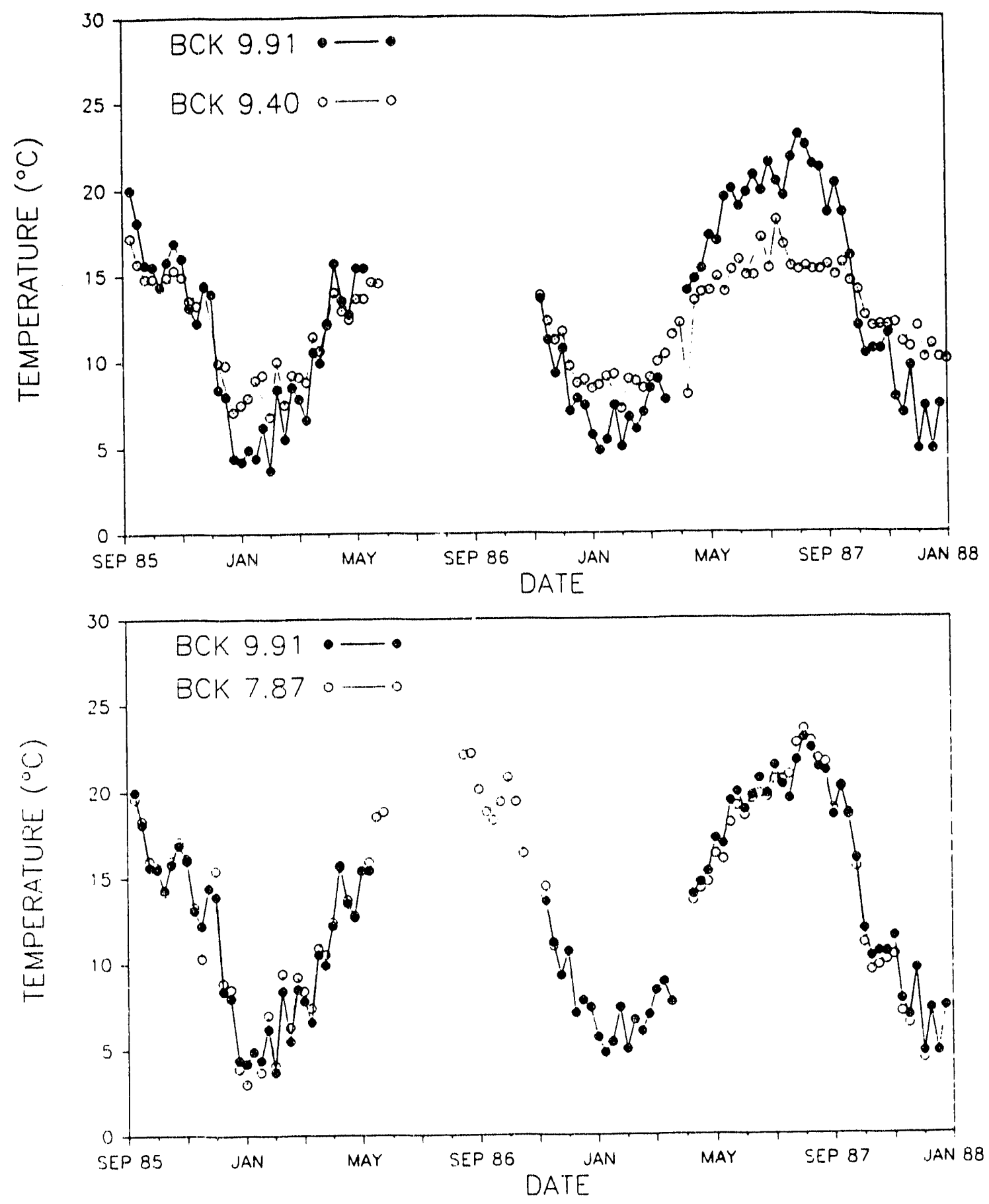

Fig. 2-6. Mean weekly temperatures in Bear Creek above SS5 (BCK 9.91), immediately below SS5 (BCK 9.40), and $1.54 \mathrm{~km}$ downstream (BCK 7.87). Prior to April 1987, data were collected at 2-h intervals using a Ryan-Peabody thermograph (Model J-90). After April 1987, a Ryan Tempmentor digital thermograph was used to obtain data at 20 -min intervals (April-June 1987) and 1-h intervals (after June 1987). 
caused by decreased stream flow during a drought is directly related to the severity of the drought.

\subsection{SUBSTRATE AND COVER}

\subsubsection{Introduction}

The biological monitoring of Bear Creek involved analysis of the fish and benthic invertebrate communities at selected study sites distributed along the length of the stream. These sites were selected to minimize differences in physical habitat that could influence the structure of biological communities. A complete analysis of physical habitat was conducted in June 1988 and included measurements of stream flow, substrate, bank cover and canopy, and the pool-to-riffle (P/R) ratio. The data included in this analysis represent habitat conditions in Bear Creek during low-flow periods and will be followed by future surveys during other times of the year.

\subsubsection{Methods}

The techniques used in the habitat survey were based on methods described in Platts et al. (1983). Two types of habitat data are included in this report. The first type includes the results of surveys that were performed at each site as part of the routine fish population sampling. These surveys included only measurements of the length of the reach, the stream width across transects located at 5-m intervals within the reach, and the depth of the stream at left midside, midstream, and right midside locations along each transect.

The second type of habitat data provided a more comprehensive characterization of the study sites. Site surveys were conducted using a nonrandom transect system. Transects were located at intervals of 5 to $15 \mathrm{~m}$ (depending on length of site and substrate heterogeneity). Some clustering of transects was included as part of the survey to ensure that all habitat types were adequately characterized. Such an approach to transect selection is acceptable when pre-existing knowledge of site conditions is great (Platts et al. 1983).

Current velocity was measured with a Marsh McBirney Mode1 210D portable electronic water current meter. Readings were taken at five 
locations along each transect: near the right and left banks, midway between each bank and the middle of the channel, and at midchannel. Depths and strean width were also recorded to calculate discharge. These measurements were taken between June 1 and June 9,1988 , a period of very low rainfall (total of $4.45 \mathrm{~mm}$ was recorded at the rain gauge near BCK 10.6; D. D. Huff, ORNL/ESD, 1988, personal conmunication to J. M. Loar, ORNL/ESD).

Substrate analysis included a description of principal cover size, degree of embeddedness, and associated aquatic plants. The substrate was described within a 0.5 . to $1-\mathrm{m}$ zone of the stream bottom at the midside and/or midstream positions (depending on stream width) on the transect. A weighted rope painted at $10-\mathrm{cm}$ intervals with alternating colors provided zones for identifying the dominant substrate type (Bain et al. 1985). A rating system based on codes for certain rock/debris types and size (Table 2-10) was used to classify the dominant substrate type in each zone. The codes reflected a general trend toward increasing substrate coarseness and complexity with increasing nubuer. By using the zones, 5 to 10 codes were generated for each transect position. The mean and standard deviation of the codes providad information on coarseness and degree of unf formity of the substrate (Bain et al. 1985). A similar approach was used to grade the embeddedness or degree that the dominant particles were covered by fine sediments in each zone (Table 2-11). Aquatic plants were also identified and their percent cover for the entire transect was estimated visually.

The stream bank cover was described for each tr. asect based on three zones: (1) vegetation overhanging the stream; (2) herbaceous cover on the bank slope; and (3) the general forest type within $10 \mathrm{~m}$ of the stream bank. This qualitative description is only briefly discussed below. Also, a measure of the riparian canopy was made at the mid-point of each transect by obtaining a percentage reading from a convex mirror with a $10 \times 10$ engraved grid. The canopy percentage represented the number of grids covered by the overhanglng vegetation and was used as a colparative measure of available sunlight (modified from Platts et al. 1983). 
Table 2-10. Substrate codes used in the physical habitat analysis of Bear Creek (adapted from Platts et al. 1983 and Bain et al. 1985). NA - Not applicable

\begin{tabular}{llc}
\hline Code & Substrate index & $\begin{array}{c}\text { Particle size range } \\
(\mathrm{mm})\end{array}$ \\
\hline 1 & Bedrock, smooth & $<2.0$ \\
2 & Clay & $<0.004$ \\
3 & Silt & $<0.004-0.062$ \\
4 & Sand/fine sediment & $0.062-2.0$ \\
5 & Gravel & $2.0-64.0$ \\
6 & Cobble/rubble & $64.0-250.0$ \\
7 & Small boulder & $250.0-610.0$ \\
8 & Large boulder & $610.0-2000.0$ \\
9 & Bedrock, rough & $>2000.0$ \\
10 & Plant detritus & $\mathrm{NA}$ \\
11 & Woody debris & $\mathrm{NA}$ \\
12 & Root wads & $\mathrm{NA}$ \\
\hline & Trash, human origin & $\mathrm{NA}$ \\
\hline
\end{tabular}


Table 2-11. Embeddedness rating for substrate material (adapted from Platts et al. 1983)

Rating

Rating description

5

4

3

2

1
Predominant particles have less than 5 percent of their surface covered by fine sediment

Predominant particles have between 5 and 25 percent of their surface covered by fine sediment

Predominant particles have between 25 and 50 percent of their urface covered by fine sediment

Predominant particles have between 50 and 75 percent of their surface covered by fine sediment

Predominant particles have more than 75 percent of their surface covered by fine sediment 


\subsubsection{Results}

The primary purpose of the habitat characterization was to provide data that could be used in the fish and benthic invertebrate community analyses; therefore, the study site descriptions are separated in that manner. Because most of the benthos sampling sites are included within or adjacent to the fish sites, the information presented in Sect. 2.3.3.1 represents the general site conditions. Any differences or conditions especially applicable to the benthos are discussed in Sect. 2.3.3.2.

\subsubsection{Fish Study Sites}

The locations of the seven fish study sites on Bear Creek are shown in Figs. 1-1 and 1\%2, and the locations of the reference sites on Mill Branch and Grassy Creek are shown in Fig. 2-7. The length, average depth, and average width of the sites, as recorded on each sampling date, are given in Table 2-12.

The lowermost site, $B C K 3.25$, is the least disturbed site on Bear Creek. It consists of a roughly $60-\mathrm{m}$ reach of stream that was wide $(4.1$ to $5.7 \mathrm{~m}$ ) and shallow with a $P / R$ ratio in June 1988 of 2.05 ('Table 2-13). The substrate was predominantly a coarse mixture of gravel, cobble, and rubble with an embeddedness between 5 and 258 . The low $S D$ of the mean substrate rating indicates a homogeneous substrate mixture. Aquatic vegetation was limited to green algae, which covered from 1 to 258 of a transect. The mean current velocity of the reach was $0.09 \mathrm{~m} / \mathrm{s}$ and ranged from 0 to $0.79 \mathrm{~m} / \mathrm{s}$; the mean depth in June 1988 was $7.3 \mathrm{~cm}$ but ranged from 2.8 to $18.2 \mathrm{~cm}$ among the eight transects (Table 2-14). The surrounding vegetation consists of a young to mature forest dominated by maple (Acer spp.), sycamore (Plantanus occidentalis), walnut (Juglans nigra), and pine (Pinus spp.). The bank cover consisted of honeysuckle (Lonicera japonica), wingstem (Verbesina spp.), sedge (Carex vulpiniodea), blackberry (Rubus allegheniensis), fescue (Festuca pratensis), and other grasses (Poa spp.). Overhanging vegetation included the larger tree cover, as well as smaller dogwood (Cornus spp.), box elder (Acer negundo), and buckeye 


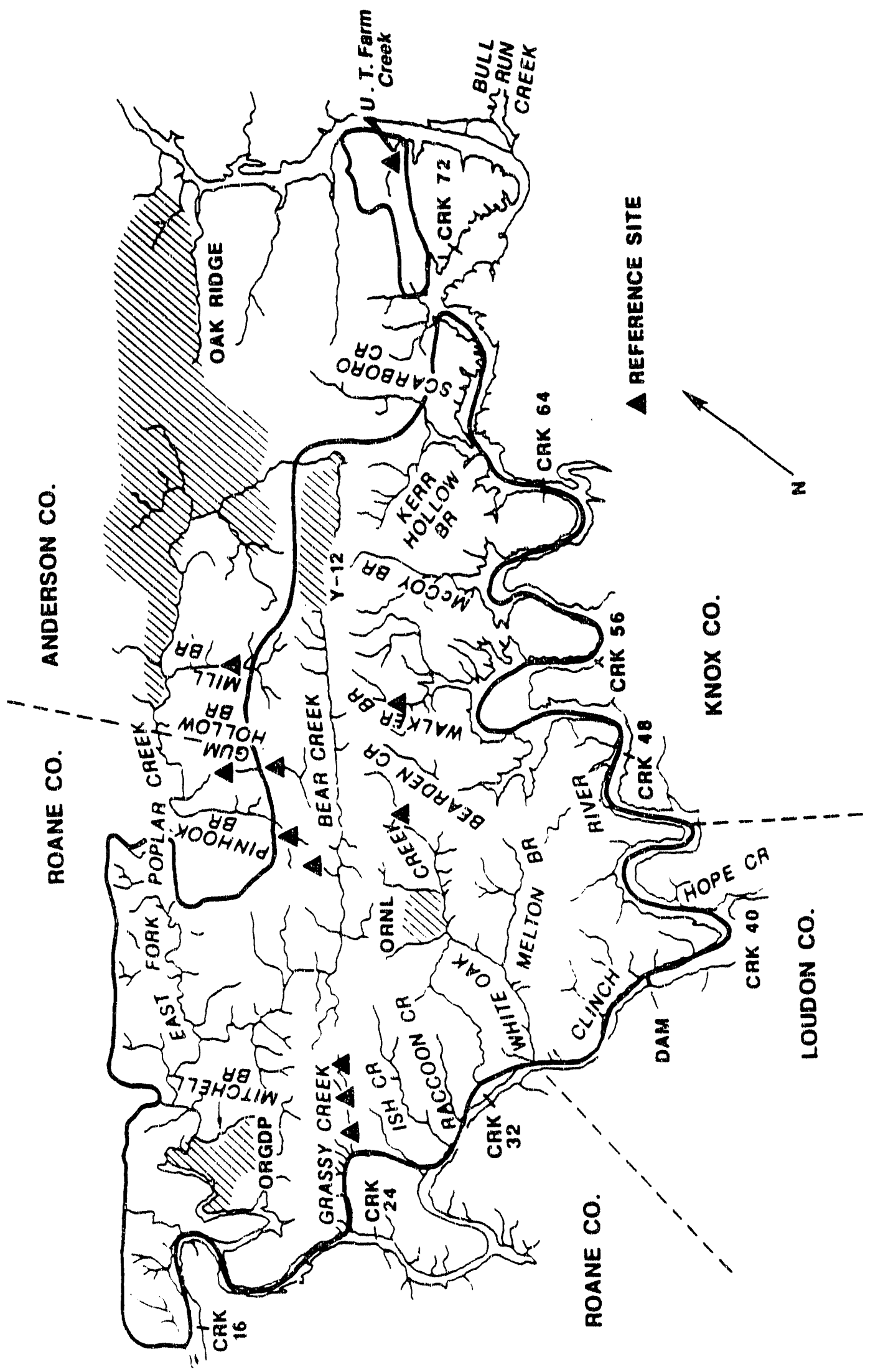

苟 
Table 2-12. Stream order, total length, mean width, wan dapth, and surface area of finh sampling sites in Bear Creak (BCK) and two reference stream, Grasyy Creak (CCK) and Mill Branch (HBK), 1984-1987. MA an Mo data evailable; MS - Sito not sampled

\begin{tabular}{|c|c|c|c|c|c|c|c|c|c|}
\hline $\begin{array}{l}\text { Sanpling poriods/ } \\
\text { parameters }\end{array}$ & $\begin{array}{c}\text { BCK } \\
12.36\end{array}$ & $\begin{array}{c}\text { BCK } \\
1.1 .83\end{array}$ & $\begin{array}{c}\text { BCK } \\
11.09\end{array}$ & $\begin{array}{l}\text { BCK } \\
9.91\end{array}$ & $\begin{array}{l}\text { BCK } \\
8.40\end{array}$ & $\begin{array}{l}\text { BCK } \\
7.87\end{array}$ & $\begin{array}{l}\text { BCK } \\
3.25\end{array}$ & $\begin{array}{l}\text { GCK } \\
2.4\end{array}$ & $\begin{array}{l}\text { MBK } \\
1.6\end{array}$ \\
\hline Stream orter & 2 & 2 & 2 & 2 & 2 & 2 & 3 & 2 & 3 \\
\hline \multicolumn{10}{|l|}{ May-June 1984} \\
\hline Length $(m)$ & 290 & 144 & 69 & 97 & 63 & 90 & 56 & 59 & NS \\
\hline Width (m) & $N A^{b}$ & 1.6 & 1.4 & 2.2 & 2.2 & 3.1 & 5.2 & 1.5 & \\
\hline Depth $(\mathrm{cm})$ & NA & $\mathrm{NA}$ & $M A$ & NA & NA & NA & NA & NA & \\
\hline Area $\left(m^{2}\right)$ & NA & 2.26 & 94 & 207 & 139 & 275 & 2.93 & 88 & \\
\hline \multicolumn{10}{|l|}{ March-April 1985} \\
\hline Length $(m)$ & 170 & 47 & 80 & 72 & 64 & 52 & 62 & 59 & 49 \\
\hline Width (m) & 1.4 & 1.4 & 2.3 & 2.7 & 2.9 & 2.9 & 4.7 & 1.6 & 2.8 \\
\hline Depth $(\mathrm{cm})$ & NA. & NA & NA & $\mathrm{KA}$ & NA & NA & NA & NA & NA \\
\hline Area $\left(m^{2}\right)$ & 232 & 67 & 204 & 193 & 186 & 150 & 291 & 93 & 136 \\
\hline \multicolumn{10}{|l|}{ July-August 1985} \\
\hline Length $(m)$ & 224 & 47 & 68 & 74 & 62 & 51 & 43 & 60 & 47 \\
\hline Width $(m)$ & 0.9 & 1.2 & 1.3 & 2.0 & 2.2 & 2.9 & 4.1 & 1.3 & 2.8 \\
\hline Depth $(\mathrm{cm})$ & 3.3 & 10.6 & 8.2 & 9.2 & 8.4 & 14.1 & 9.0 & 8.2 & 6.7 \\
\hline Area $\left(m^{2}\right)$ & 199 & 57 & 86 & 149 & 135 & 148 & 177 & 76 & 134 \\
\hline \multicolumn{10}{|c|}{ November-December 1985} \\
\hline Length $(m)$ & 214 & 46 & 68 & 70 & 65 & 48 & 60 & 60 & 50 \\
\hline Width $(m)$ & 1.1 & 1.2 & 1.8 & 2.2 & 2.2 & 3.1 & 5.5 & 1.8 & 3.0 \\
\hline Depth $(\mathrm{cm})$ & 3.9 & 9.5 & 9.0 & 9.5 & 10.3 & 16.7 & 15.9 & 7.7 & 9.2 \\
\hline Area $\left(m^{2}\right)$ & 242 & 57 & 120 & 151 & 142 & 150 & 329 & 107 & 151 \\
\hline \multicolumn{10}{|l|}{ March-April 2986} \\
\hline Length $(m)$ & 176 & 59 & 70 & 69 & 60 & 47 & 59 & 61 & 49 \\
\hline Width $(m)$ & 1.3 & 1.2 & 2.1 & 2.2 & 2.7 & 3.0 & 5.3 & 1.5 & 3.1 \\
\hline Depth $(\mathrm{cm})$ & 3.8 & 9.2 & 10.5 & 12.8 & 11.7 & 15.8 & 13.2 & 8.8 & 7.5 \\
\hline Area $\left(m^{2}\right)$ & 226 & 70 & 1.48 & 154 & 162 & 141 & 311 & 89 & 152 \\
\hline \multicolumn{10}{|c|}{ November-January $1986 / 87$} \\
\hline Length $(\mathrm{m})$ & 277 & 43 & 67 & 69 & 63 & 49 & 58 & 58 & 49 \\
\hline Width $(m)$ & 1.2 & 1.0 & 1.8 & 2.5 & 2.4 & 3.1 & 5.6 & 1.7 & 3.1 \\
\hline Depth $(\mathrm{cm})$ & 4.2 & 12.0 & 9.8 & 11.1 & 11.0 & 13.4 & 13.5 & 10.4 & 7.8 \\
\hline Area $\left(m^{2}\right)$ & 216 & 43 & 122 & 175 & 15.1 & 151 & 325 & $8 \%$ & 153 \\
\hline \multicolumn{10}{|l|}{ March-Apr 111987} \\
\hline Length (m) & 177 & 43 & 68 & 72 & 64 & 48 & 59 & 59 & 50 \\
\hline Width $(m)$ & 1.5 & 1.4 & 2.3 & 2.7 & 3.1 & 3.5 & 5.7 & 1.6 & 3.2 \\
\hline Depth $(\mathrm{cm})$ & 5.6 & 8.2 & 14.5 & 15.0 & 15.0 & 20.6 & 15.4 & 9.6 & 10.7 \\
\hline Area $\left(m^{2}\right)$ & 272 & 62 & 153 & 194 & 196 & 170 & 338 & 96 & 159 \\
\hline \multicolumn{10}{|c|}{ October-November 1987} \\
\hline Length (m) & 176 & 43 & 60 & 69 & 64 & 46 & 76 & 57 & 51 \\
\hline Width (m) & 1.2 & 0.8 & 0.9 & 2.5 & 2.1 & 3.1 & 4.7 & 1.2 & 2.9 \\
\hline Depth $(\mathrm{cm})$ & 3.4 & 6.1 & 5.3 & 9.9 & 9.5 & 12.5 & 11.0 & 7.2 & 8.0 \\
\hline Area $\left(\mathrm{m}^{2}\right)$ & 210 & 34 & 51 & 104 & 134 & 43 & 3.57 & 67 & 148 \\
\hline
\end{tabular}


Table 2-13. Substrate rating, embeddedness rating, percent canopy, and $P / R$ ratio for fish sampling sites in Bear Creek (BCK) and two reference streams, Grassy Creek (GCK) and Mill Branch (MBK), June 1988.

Values are the mean ( $\pm S D$ )

\begin{tabular}{lllll}
\hline Site & Substrate & Embeddedness & $\begin{array}{c}\text { P/R } \\
\text { ratio }\end{array}$ \\
\hline BCK 3.25 & $5.27 \pm 0.69$ & $3.63 \pm 1.47$ & $66.9 \pm 12.5$ & 2.05 \\
BCK 7.87 & $5.40 \pm 2.74$ & $2.56 \pm 1.77$ & $72.0 \pm 18.7$ & 4.75 \\
BCK 9.40 & $5.02 \pm 2.97$ & $3.29 \pm 1.82$ & $77.7 \pm 5.7$ & 1.46 \\
BCK 9.91 & $5.65 \pm 2.67$ & $2.33 \pm 1.54$ & $86.0 \pm 9.6$ & 3.12 \\
BCK 11.09 & $4.13 \pm 1.04$ & $1.90 \pm 1.18$ & $59.6 \pm 18.3$ & 22.0 \\
BCK 11.83 & $4.15 \pm 1.69$ & $2.0 \pm 1.52$ & $61.3 \pm 21.9$ & 0.73 \\
BCK 12.36 & $5.50 \pm 1.73$ & $1.96 \pm 1.35$ & $55.1 \pm 36.7$ & 1.70 \\
GCK 2.4 & $5.17 \pm 1.79$ & $2.0 \pm 1.39$ & $72.8 \pm 23.5$ & 25.0 \\
MBK 1.6 & $5.22 \pm 2.60$ & $2.54 \pm 1.54$ & $81.0 \pm 9.1$ & 1.93 \\
\hline
\end{tabular}


Table 2-14. Mean and maximum current velocity and mean depth for each transect and for the entire reach/site (all transects combined) at the fish and benthic invertebrate sampling stations on Bear Creek (BCK), Bear Creek Trlbutary (BTK), Clear Creek (CCK), Grassy Creek (GCK), Gum Hollow Branch (GHK), Hinds Creek (HCK), Mill Branch (MBK), Pinhook Branch (PHK), UT Farm Creek (UTK), and Walker Branch (WBK), June 1988. SD = Standard deviation

\begin{tabular}{|c|c|c|c|c|c|c|}
\hline \multirow{2}{*}{$\begin{array}{l}\text { Site/ } \\
\text { transect }\end{array}$} & \multicolumn{4}{|c|}{ Velocity $(\mathrm{m} / \mathrm{s})$} & \multicolumn{2}{|c|}{ Depth $(\mathrm{cm})$} \\
\hline & Mean & SD & Minim & ximum & Mean & $\mathrm{SD}$ \\
\hline \multicolumn{7}{|l|}{ BCK 3.25} \\
\hline SRI & 0.14 & 0.17 & 0 & 0.37 & 4.0 & 2.4 \\
\hline T]. & 0.41 & 0.32 & 0 & 0.79 & 3.8 & 2.0 \\
\hline $\mathrm{T} 2$ & 0.07 & 0.11 & 0 & 0.25 & 3.2 & 3.0 \\
\hline T3 & 0.03 & 0.05 & 0 & 0.12 & 3.6 & 2.7 \\
\hline T4 & 0.02 & 0.04 & 0 & 0.09 & 8.6 & 7.9 \\
\hline T5 & 0.03 & 0.03 & 0 & 0.07 & 10.8 & 9.7 \\
\hline T6 & 0.01 & 0.03 & 0 & 0.06 & 2.8 & 2.3 \\
\hline T7 & 0.04 & 0.08 & 0 & 0.18 & 18.2 & 14.0 \\
\hline ALL & 0.09 & 0.19 & 0 & 0.79 & 7.3 & 8.5 \\
\hline \multicolumn{7}{|l|}{$\mathrm{BCK} 7.87$} \\
\hline SR1 & 0.04 & 0.04 & 0 & 0.09 & 2.8 & 2.7 \\
\hline $\mathrm{T} 1$ & 0.02 & 0.03 & 0 & 0.08 & 6.6 & 7.0 \\
\hline $\mathrm{T} 2$ & 0.01 & 0.01 & 0 & 0.02 & 14.0 & 8.5 \\
\hline $\mathrm{T} 3$ & 0 & 0 & 0 & 0 & 19.0 & 14.4 \\
\hline $\mathrm{T} 4$ & 0 & 0 & 0 & 0 & 13.0 & 10.0 \\
\hline ALL & 0.02 & 0.03 & 0 & 0.09 & 11.1 & 10.3 \\
\hline \multicolumn{7}{|l|}{ BCK 9.40} \\
\hline SRI & 0.08 & 0.09 & 0 & 0.23 & 2.0 & 1.6 \\
\hline $\mathrm{T} 1$ & 0.05 & 0.05 & 0 & 0.11 & 6.2 & 5.5 \\
\hline $\mathrm{T} 2$ & 0.02 & 0.04 & 0 & 0.09 & 2.6 & 1.9 \\
\hline T3 & 0.01 & 0.02 & 0 & 0.04 & 18.0 & 9.9 \\
\hline $\mathrm{T} 4$ & 0.01 & 0.01 & 0 & 0.02 & 6.6 & 3.6 \\
\hline T5 & 0.01 & 0.02 & 0 & 0.03 & 2.4 & 1.7 \\
\hline ALL & 0.03 & 0.05 & 0 & 0.23 & 6.3 & 7.2 \\
\hline \multicolumn{7}{|l|}{ BCK 9.91} \\
\hline SR1 & 0.02 & 0.02 & 0 & 0.05 & 1.8 & 1.1 \\
\hline $\mathrm{T} 1$ & 0.03 & 0.06 & 0 & 0.13 & 1.6 & 2.2 \\
\hline$T 2-A^{b}$ & 0 & 0 & 0 & 0 & 6.6 & 5.0 \\
\hline $\mathrm{T} 2-\mathrm{B}^{\mathrm{b}}$ & 0.07 & 0.08 & 0 & 0.16 & 1.2 & 1.1 \\
\hline T3 & 0.02 & 0.02 & 0 & 0.05 & 4.8 & 3.6 \\
\hline$T 4$ & 0 & 0 & 0 & 0 & 30.4 & 26.3 \\
\hline
\end{tabular}


Table 2-14 (continued)

\begin{tabular}{|c|c|c|c|c|c|c|}
\hline \multirow{2}{*}{$\begin{array}{l}\text { Site/ } \\
\text { transecta }\end{array}$} & \multicolumn{4}{|c|}{ Velocity $(\mathrm{m} / \mathrm{s})$} & \multicolumn{2}{|c|}{ Depth $(\mathrm{cm})$} \\
\hline & Mean & SD & Minim & ximum & Mean & SD \\
\hline T5 & 0 & 0 & 0 & 0 & 3.0 & 2.0 \\
\hline $\mathrm{T} 6$ & $<0.01$ & 0.01 & 0 & 0.01 & 13.4 & 12.4 \\
\hline ALL & 0.02 & 0.04 & 0 & 0.16 & 7.9 & 13.4 \\
\hline \multicolumn{7}{|l|}{ BCK 11.09} \\
\hline SR1 & 0 & 0 & 0 & 0 & 0 & 0 \\
\hline SR2 & 0 & 0 & 0 & 0 & 0 & 0 \\
\hline T1 & 0 & 0 & 0 & 0 & 1.0 & 0 \\
\hline T2 & 0 & 0 & 0 & 0 & 10.0 & 5.0 \\
\hline T3 & $<0.01$ & $<0.01$ & 0 & 0.01 & 29.2 & 16.5 \\
\hline T4 & $<0.01$ & $<0.01$ & 0 & 0.01 & 7.2 & 6.4 \\
\hline T5 & 0 & 0 & 0 & 0 & 10.8 & 8.1 \\
\hline ALL & $<0.01$ & $<0.01$ & 0 & 0.01 & 10.8 & 12.5 \\
\hline \multicolumn{7}{|l|}{$\mathrm{BCK} 11.83$} \\
\hline SR1 & 0 & 0 & 0 & 0 & 0 & 0 \\
\hline $\mathrm{T1}$ & 0.02 & 0.03 & 0 & 0.07 & 1.8 & 1.1 \\
\hline $\mathrm{T} 2$ & 0.01 & 0.02 & 0 & 0.04 & 2.2 & 1.8 \\
\hline T3 & 0.02 & 0.02 & 0 & 0.04 & 1.6 & 1.7 \\
\hline T4 & 0 & 0 & 0 & 0 & 16.4 & 6.5 \\
\hline T5 & 0.02 & 0.03 & 0 & 0.07 & 4.0 & 1.4 \\
\hline $\mathrm{T} 6$ & 0.01 & 0.03 & 0 & 0.06 & 2.8 & 2.9 \\
\hline T7 & 0.05 & 0.06 & 0 & 0.15 & 1.6 & 1.5 \\
\hline T8 & 0.01 & 0.01 & 0 & 0.02 & 5.8 & 4.8 \\
\hline T9 & 0.03 & 0.05 & 0 & 0.10 & 3.2 & 2.3 \\
\hline $\mathrm{T} 10$ & 0.02 & 0.02 & 0 & 0.05 & 5.2 & 3.3 \\
\hline ALL & 0.02 & 0.03 & 0 & 0.15 & 4.1 & 5.1 \\
\hline \multicolumn{7}{|l|}{ BCK 12.36} \\
\hline SR1 & 0.02 & 0.03 & 0 & 0.06 & 2.6 & 1.7 \\
\hline $\mathrm{T} 1$ & $<0.01$ & $<0.01$ & 0 & 0.01 & 7.0 & 3.7 \\
\hline $\mathrm{T} 2$ & 0.08 & 0.09 & 0 & 0.21 & 1.4 & 1.3 \\
\hline T3 & $<0.01$ & 0.01 & 0 & 0.02 & 3.4 & 3.1 \\
\hline $\mathrm{T} 4$ & 0.01 & 0.01 & 0 & 0.03 & 2.0 & 1.4 \\
\hline T5 & $<0.01$ & $<0.01$ & 0 & 0.01 & 4.6 & 1.7 \\
\hline $\mathrm{T} 6$ & 0.03 & 0.03 & 0 & 0.07 & 1.6 & 0.9 \\
\hline $\mathrm{T} 7$ & 0.02 & 0.03 & 0 & 0.06 & 2.0 & 2.0 \\
\hline T8 & 0.02 & 0.02 & 0 & 0.05 & 2.6 & 1.7 \\
\hline T9 & 0.01 & 0.01 & 0 & 0.02 & 6.8 & 5.4 \\
\hline
\end{tabular}


Table 2-14 (continued)

\begin{tabular}{|c|c|c|c|c|c|c|}
\hline \multirow{2}{*}{$\begin{array}{l}\text { Site/ } \\
\text { transecta }\end{array}$} & \multicolumn{4}{|c|}{ Velocity $(\mathrm{m} / \mathrm{s})$} & \multicolumn{2}{|c|}{ Depth $(\mathrm{cm})$} \\
\hline & \multirow{2}{*}{$\begin{array}{l}\text { Mean } \\
0.06\end{array}$} & \multirow{2}{*}{$\begin{array}{l}\text { SD } \\
0.14\end{array}$} & \multicolumn{2}{|c|}{ Minimum Maximum } & \multirow{2}{*}{$\begin{array}{r}\text { Mean } \\
1.2\end{array}$} & \multirow{2}{*}{$\frac{S D}{1.6}$} \\
\hline $\mathrm{T} 10$ & & & 0 & 0.31 & & \\
\hline $\mathrm{T} 11$ & 0.02 & 0.02 & 0 & 0.04 & 3.2 & 1.9 \\
\hline ALL & 0.02 & 0.05 & 0 & 0.31 & 3.2 & 3.0 \\
\hline \multicolumn{7}{|l|}{ BTK 0.3} \\
\hline SR 1 & 0 & 0 & 0 & 0 & 1.6 & 0.9 \\
\hline \multicolumn{7}{|l|}{$\operatorname{CCK} 0.3$} \\
\hline SR1 & 0.03 & 0.06 & 0 & 0.18 & 3.8 & 3.0 \\
\hline \multicolumn{7}{|l|}{$\operatorname{GCK} 2.4$} \\
\hline SR1 & 0 & 0 & 0 & 0 & 0 & 0 \\
\hline $\mathrm{T} 1$ & 0 & 0 & 0 & 0 & 0 & 0 \\
\hline $\mathrm{T} 2$ & 0 & 0 & 0 & 0 & 2.4 & 2.3 \\
\hline T3 & 0 & 0 & 0 & 0 & 9.0 & 5.7 \\
\hline T4 & 0 & 0 & 0 & 0 & 1.2 & 1.1 \\
\hline T5 & 0 & 0 & 0 & 0 & 3.2 & 3.0 \\
\hline T6 & 0 & 0 & 0 & 0 & 0.8 & 1.1 \\
\hline $\mathrm{T} 7$ & $<0.01$ & $<0.01$ & 0 & 0.01 & 10.4 & 8.2 \\
\hline T8 & $<0.01$ & $<0.01$ & 0 & 0.01 & 22.2 & 14.6 \\
\hline T9 & 0 & 0 & 0 & 0 & 0 & 0 \\
\hline T10 & 0 & 0 & 0 & 0 & 0 & 0 \\
\hline T11 & 0 & 0 & 0 & 0 & 0 & 0 \\
\hline ALL & $<0.01$ & $<0.01$ & 0 & 0.01 & 4.1 & 8.0 \\
\hline \multicolumn{7}{|l|}{ GHK 1.6} \\
\hline SR1 & 0.07 & 0.10 & 0 & 0.26 & 1.9 & 1.2 \\
\hline \multicolumn{7}{|l|}{ GHK 2.9} \\
\hline SRI & 0 & 0 & 0 & 0 & 2.0 & 0 \\
\hline \multicolumn{7}{|l|}{$\operatorname{HCK} 12.9$} \\
\hline SR1 & 0.17 & 0.18 & 0 & 0.36 & 4.6 & 4.2 \\
\hline \multicolumn{7}{|l|}{ MBK 1.6} \\
\hline SR1 & 0.04 & 0.06 & 0 & 0.15 & 2.0 & 1.2 \\
\hline $\mathrm{T} 1$ & 0.01 & 0.01 & 0 & 0.03 & 9.2 & 3.3 \\
\hline $\mathrm{T} 2$ & 0.01 & 0.02 & 0 & 0.05 & 5.6 & 4.9 \\
\hline $\mathrm{T} 3$ & 0.01 & 0.02 & 0 & 0.05 & 5.8 & 6.2 \\
\hline T4 & 0.09 & 0.13 & 0 & 0.25 & 2.4 & 2.6 \\
\hline
\end{tabular}


Table 2-14 (continued)

\begin{tabular}{|c|c|c|c|c|c|c|}
\hline \multirow{2}{*}{$\begin{array}{l}\text { Site/ } \\
\text { transect }\end{array}$} & \multicolumn{4}{|c|}{ Velocity $(\mathrm{m} / \mathrm{s})$} & \multicolumn{2}{|c|}{ Depth $(\mathrm{cm})$} \\
\hline & Mean & SD & Minim & ximum & Mean & SD \\
\hline T5 & 0.01 & 0.02 & 0 & 0.04 & 10.0 & 9.7 \\
\hline ALL & 0.03 & 0.06 & 0 & 0.25 & 5.8 & 5.8 \\
\hline $\begin{array}{c}\text { PHK } 1.4 \\
\text { SR } 1\end{array}$ & 0.01 & 0.03 & 0 & 0.06 & 0.4 & 0.9 \\
\hline $\begin{array}{c}\text { UTK } 0.6 \\
\text { SRI }\end{array}$ & 0.07 & 0.08 & 0 & 0.19 & 1.6 & 1.5 \\
\hline $\begin{array}{c}\text { WBK } 1.0 \\
\text { SR1 }\end{array}$ & 0.06 & 0.05 & 0 & 0.14 & 2.8 & 1.9 \\
\hline
\end{tabular}

${ }^{\text {aSR }}=$ Benthic invertebrate sampling site.

bransects separated by an island. 
(Aesculus spp.). The resulting canopy covered about two-thirds of the stream with most transects showing similar coverage (Table 2-13).

The next upstream site, BCK 7.87 , is a shorter $(\sim 50 \mathrm{~m})$, narrower $(2.9$ to $3.5 \mathrm{~m}$ ), and deeper reach with a higher $P / R$ ratio $(4.75)$ than BCK 3.25. The maximum current velocity was only $0.09 \mathrm{~m} / \mathrm{s}$ and the average water depth was $11.1 \mathrm{~cm}$. The substrate was a mixture of gravel, silt, and woody debri.s. The high SD indicated a heterogeneous mixture of substrate types. The embeddedness was moderate with about 508 of the surface area of the dominant particles covered by fine sediment. Another change in the structure of the stream was the occurrence of undercut banks, which were not found at BCK 3.25. All of these characteristics reflected the dominance of pool features in this reach of Bear Creek. The forest was similar to that at BCK 3.25 , but tulip poplax (Liriodendron tulipifera) and hanging vegetation were more abundant at $B C K$ 7.87. The bank cover was dominated by Virginia creeper (Parthenocissus quinquefolia), honeysuckle, poison ivy (Toxicodendron radicans), and paric grasses (Panicum spp.). The overhanging vegetation, including spicebush (Lindera benzoin), sycamore, redbud (Cercis canadensis), slippery elm (Ulmus rubra), and red cedar (Juniperus virginiana), had a mean canopy of 728 with high variability between transects. The vegetation at the site is also influenced by Bear Creek Road, which is located at the head of the study reach.

The upstream trend toward decreasing stream width continued at the next site (BCK 9.40). This site was also shallower than $B C K 7.87$, thus reflecting an increase in riffle areas $(P / R$ ratio $=1.46)$. The mean depth was $6.3 \mathrm{~cm}$ and the mean current velocity was $0.03 \mathrm{~m} / \mathrm{s}$. Pools occur in this section and undercut banks provide excellent cover areas. The substrate was a heterogeneous, coarse mixture with gravel, smoorh bedrock, woody debris, and fine sediment among the more prominent types. Embeddedness was low to moderate (between 5 and 508) and highly variable. Aquatic vegetation at BCK 9.40 included green algae, mosses, and watercress (Nasturtium officinale), which ranged in cover from 1 to 20\%. Current velocities in June ranged from 0 to $2.3 \mathrm{~cm} / \mathrm{s}$. The surrounding vegetation consisted of mature trees (walnut, maple, and sycamore) at the lower end of the site to small trees and shrubs, such 
as ironwood (Carpinus caroliniana), dogwood, slippery elm, and spicebush, near the road cut at the head of the site. Bank vegetation included Christmas fern (Polystichum acrostichoides), clearweed (Pilea pumila), catbriar (Smilax spp.), poison ivy, honeysuckle, and Virginia creeper. The overhanging vegetation provided a consistent, dense cover with a mean canopy of 77.78 .

Although the next site, BCK 9.91, had a similar mean depth and width to BCK 9.40 (Table 2-12), the physical habitat at BCK 9.91 was different and less uniform. The site was dominated by a large, deep pool in the center of the reach with several smaller pools separated by shallow riffles above and below it. The site had a relatively high $P / R$ ratio of 3.12 , and undercut banks were an important feature of the pool habitats. The substrate was highly variable and consisted primarily of gravel, woody debris, and clay (Table 2-13). The high embeddedness ( 25 to $75 \%$ ) was related to extensive pool but limited riffle areas. Mean depths ranged from 1.2 to $30.4 \mathrm{~cm}$ and mean current velocities were low $(0$ to $0.07 \mathrm{~m} / \mathrm{s})$. The surrounding forest had the appearance of wet lowland habitat and included maple, walnut, slippery elm, sycamore, and tulip poplar. The bank vegetation was very sparse; some areas had no cover and others were dominated by vines, such as Virginia creeper and honeysuckle. The overhanging vegetation, including ash (Fraxinus americana), redbud, and spicebush, gave BCK 9.91 the densest canopy (868) of any Bear Creek site.

The remaining three upstream sites are located in a more highly disturbed area of Bear Creek. BCK 11.09 is narrower and shallower than BCK 9.91. Due to the extremely low-flow conditions that typically occur in this section of Bear Creek in summer, no riffle habitat was present when the habitat survey was conducted. The sampling reach consisted of a series of isolated pools; maximum current velocities did not exceed $0.01 \mathrm{~m} / \mathrm{s}$ and mean depths ranged from 0 to $29.2 \mathrm{~cm}$ among the seven transects. The substrate consisted of a homogeneous mixture of sand/fine sediments and gravel (Table 2-13) with an embeddedness near 758. The surrounding vegetation also showed evidence of disturbance. Sinall trees and shrubs, such as sycamore, pine, and smooth sumac (Rhus glabra), were prevalent, but few mature trees were present. The bank 
vegetation included honeysuckle, blackberry, poison ivy, clearweed, and ragweed (Ambrosia artemisiifolia). Overhanging vegetation was sparse (canopy of 59.68) and consisted of dogwood, sassafras (Sassafras albidum), sycamore, and walnut.

The sampling site at $B C K 11.83$ was generally not as wide nor as intermittent in flow as that at $B C K 11.09$ and had a $P / R$ ratio of only 0.73. Mean current velocities ranged from 0 to $0.05 \mathrm{~m} / \mathrm{s}$ and mean depths ranged from 0 to $16.4 \mathrm{~cm}$ among the 11 transects. The substrate was a uniform mixture of gravel, sand/fine sediment, and silt with an embeddedness between 50 and 758 . The surrounding and overhanging vegetation indicated a very disturbed condjtion with small trees (box elder, smooth sumac, slippery elm, willow (Salix spp.), pine], shrubs, and meadow grasses dominating. The bank vegetation included blackberry, poison ivy, meadow fescue (Festuca protensis), and other grasses, resulting in a relatively open canopy ( 61.38$)$.

The uppermost site, $B C K 12.36$, was a long $(-200 \mathrm{~m})$, narrow, shallow reach with a $P / R$ ratio of 1.70 . The substrate was a coarse mixture of gravel, plant detritus, and sand/fine sediment with a high degree of embeddedness (Table 2-13). Mean current velocities at the 12 transects ranged from $<0.01$ to $0.06 \mathrm{~m} / \mathrm{s}$; mean depths ranged from 1.4 to $7.0 \mathrm{~cm}$. Surrounding vegetation reflected an extremely young forest and weedy fields within a power line right-of-way. Typical overhanging cover included sycamore, sweet gum (Liquidambar styraciflua), tulip poplar, walnut, and smooth sumac with clinging honeysuckle and grape (Vitis spp.) vines. Bank cover reflected the meadow influences with grasses, fescue, ragweed, blackberry, Virginia creeper, and catbriar. The combination of small trees and open meadows resulted in the most open canopy (55.18) of any Bear Creek site.

The two reference sites had characteristics similar to the lower and upper reaches of Bear Creek. Upper Grassy Creek at GCK 2.4 was similar in width and depth to upper Bear Creek (Table 2-12) and had some dry riffle areas in June 1988. The $P / R$ ratio of 25.0 was about the same as that at BCK 11.09 (Table 2-13). The maximum current velocity was $0.01 \mathrm{~m} / \mathrm{s}$ and mean depth ranged from 0 to $22.2 \mathrm{~cm}$. Refuges were provided by the deep pools. The substrate was a coarse mixture of cobble, 
gravel, and fine sediment with a high degree of embeddedness (Table 2-13). The surrounding vegetation was a combination of a young forest on the north bank and open field with early successional forest on the south bank. Typical cover included redbud, ironwood, persimnon (Diospyros virginiana), red cedar, and sweet gum; smooth sumac was the dominant species in the open field. Overhanging vegetation included the above trees as well as birch (Betula spp.) and dogwood; redbud and red cedar were the dominant species in the canopy (72.8\%). Bank vegetation changed from honeysuckle, fescue, blackberry and multiflora rose (Rosa multiflora) at the road cut on the lower end of the section to a more diverse and establishec cover that included Christmas ferns, spicebush, and wild yam (Discorea villosa) at the upper end of the site.

The reference site on Mill Branch, MBK 1.6, was similar to lower Bear Creek. Although the average width and depth were less than in Bear Creek (Table 2-12), the $P / R$ ratios of the two streams were comparable (Table 2-13). The substrate was a coarse heterogeneous mixture consisting primarily of gravel, smooth bedrock, and cobble (Table 2-13). The embeddedness ranged from 25 to 758 but was highly variable between transects. Aquatic vegetation was limited to green algae that covered 10 of one transect, although a thick bed of watercress was observed in the study reach. The mean current velocity for the entire reach was $0.03 \mathrm{~m} / \mathrm{s}$, but velocities ranged from 0 to 0.25 $\mathrm{m} / \mathrm{s}$; the mean depth was $5.8 \mathrm{~cm}$ and ranged $\mathrm{fi}, \mathrm{m} 2.0$ to $10.0 \mathrm{~cm}$ among the six transects (Table 2-14). The surrounding vegetation consisted of an open, grassy field with small trees and shrubs on one bank and a young forest with some mature trees on the other. Common plants included beech (Fagus grandifolia), sycamore, whits ak (Quexcus alba), magnolia (Magnolia spp.), slippery elm, and buck, 3 . Orerbaging vegt tation was dense (81.08 canopy) and, in addition :0 the above trees, included tulip poplar, sweet gum, hazelnut (Corylus spp.), and willow. Bank vegetation included grasses (Festuca, Poa, and Panicum spp.), honeysuckle, and wingstem on the field side, and Christmas ferns, violet (Viola spp.), Virginia creeper, poison ivy, sedge, and grape vines on the forest side. 


\subsubsection{Benthic Macroinvertebrate Study Sites}

The locations of the Bear Creek study sites are shown in Figs. 1-1 and 1-2, and the locations of the reference sites are shown in Figs. 2-7 and 2-8. The habitat characterization for the benthic macroinvertebrate sites was conducted concurrently with the characterization of the fish sampling reaches, which, in most cases, included the riffle area(s) that were sampled for benthos. Because the fish sampling reaches were larger, habitat characteristics differed from those of the benthic sites. Depending upon the width of the stream, 5 to 30 measurements of the substrate and the degree of embeddedness were taken along a single transect across the riffle. Five measurements of current velocity and one estimate of pexcent canopy were taken along this same transect. The results of the benthos site characterization are presented in Tables 2-14 and 2-15. Substrate and cover at two Bear Creek sites (BCK 5.15 and $B C K 10.32$ ) and five reference sites (BFK 11.2, GCK 1.4, GCK 2.7, HCK 25.4, and WCK 6.8) were not characterized because the frequency of the benthic invertebrate sampling at these sites was limited.

All the Bear Creek berthos sites were second-order streams except BCK 3.25, which was a third-order stream (Table 2-14). Only one reference site (BTK 0.3) was not a second- or a third-order stream. Caropy cover at most Bear Creek and reference sites exceeded 708 (Table 2-15). The least shaded site vas BCK 12.36 (30\% canopy), which is located in the highly disturbed reaches of the stream just below the $S-3$ ponds.

A description of the vegetation and general forest type of the Bear Creek, Grassy Creek, and Mill Branch sites was discussed previously in Sect. 2.3.3.1. Following the classification system given in Parr and Pounds (1987), the remaining reference sites belong to nne of four generalized forest types. Most sites had some trees that are typical of the riparian vegetation in bottomland hardwood forests (i.e., sycamore and ironwood). Although the site on Hinds Creek at HCK 20.6 was the only one similar to a true bottomland hardwood forest, it was bordered by a pasture on one bank and had some erosional features. Five other sites (IDP 1.0, Cok 0.6, IITK 0.6, SHK 1.6 ; and GHK 2.9) were located in an oak-hickory forest: but some (CCK 0.6, GHK 1.6, GHK 2.9) bordered 

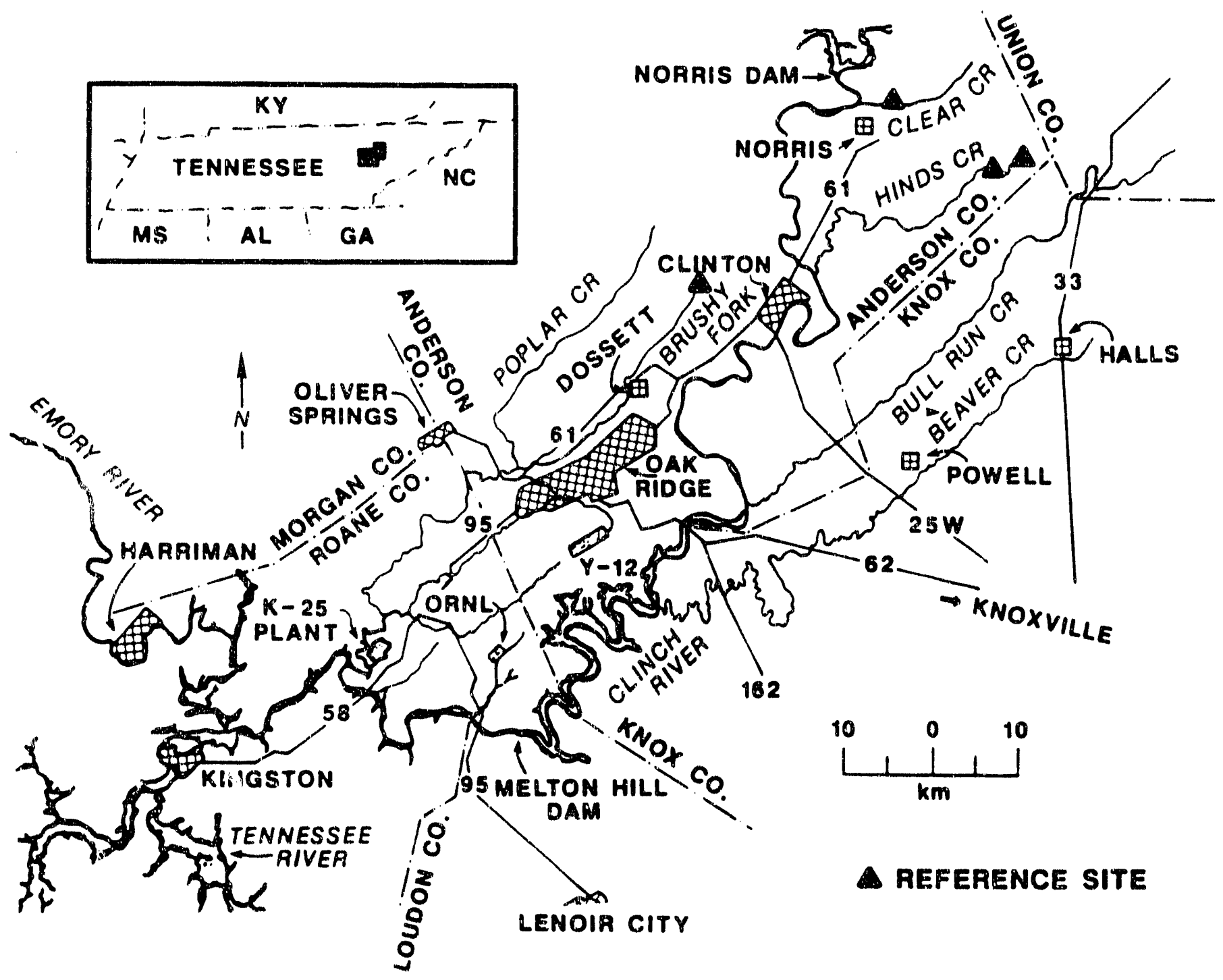

Fig. 2-8. Map of the Oak Ridge area showing the location of the far off-site ecological reference sites. 
Table 2-15. Stream order, substrate rating, embeddedness rating, and percent canopy for benthic macroinvertebrate sampling sites on Bear Creek (BCK), Grassy Creek (GCK), Mill Branch (MBK), Bear Creek Tributary (BTK), PInhook Branch (PHK), Gum Hollow Branch (GHK), UT Farm Creek (UTK), Walker Branch (WBK), Hinds Creek (HCK), and Clear Creek (CCK), June 1988. Values are the mean $( \pm S D)$, except canopy where $\mathrm{n}=1$. Data on velocity and depth are given in Table 2-14

\begin{tabular}{|c|c|c|c|c|}
\hline Site & $\begin{array}{l}\text { Streain } \\
\text { order }\end{array}$ & Substrate & Embeddedness & Canopy \\
\hline BCK 3.25 & 3 & $5.3 \pm 0.46$ & 5.0 & 82 \\
\hline BCK 7.87 & 2 & $4.9 \pm 0.32$ & $3.4 \pm 0.52$ & 84 \\
\hline BCK 9.40 & 2 & $5.2 \pm 0.42$ & $4.8 \pm 0.42$ & 78 \\
\hline BCK 9.91 & 2 & $5.0^{\circ}$ & $3.2 \pm 1.30$ & 86 \\
\hline BCK 11.09 & 2 & DRY & DRY & $80^{b}$ \\
\hline $\mathrm{BCK} 11.83$ & 2 & $5.2 \pm 0.42$ & $4.0 \pm 0.67$ & 63 \\
\hline BCK 12.36 & 2 & $2.0^{a}$ & $1.0^{\circ}$ & 30 \\
\hline GCK 2.4 & 3 & DRY & DRY & 88 \\
\hline MBK 1.6 & 3 & $5.4 \pm 0.51$ & $5.0^{a}$ & 85 \\
\hline BTK 0.3 & 1 & $5.6 \pm 0.55$ & $4.2 \pm 1.30$ & 85 \\
\hline PHK 1.4 & 2 & $4.6 \pm 0.89$ & $3.4 \pm 1.52$ & 67 \\
\hline GHK 1.6 & 3 & $6.3 \pm 2.46$ & $4.7 \pm 1.05$ & 89 \\
\hline GHK 2.6 & 2 & $5.6 \pm 0.52$ & $4.6 \pm 0.84$ & 75 \\
\hline UTK 0.6 & 2 & $5.7 \pm 0.46$ & $5.0^{\circ}$ & 61 \\
\hline WBK 1.0 & 2 & $6.0 \pm 1.9$ & $5.0^{\circ}$ & 70 \\
\hline $\mathrm{HCK} \quad 20.6$ & 3 & $8.0 \pm 1.6$ & $4.6 \pm 0.68$ & 80 \\
\hline $\operatorname{CCK} 0.6$ & 3 & $6.4 \pm 2.4$ & $4.6 \pm 0.55$ & 76 \\
\hline
\end{tabular}

${ }^{a} S D=0$.

$b_{n}=2$. 
areas of various degrees of disturbance. For example, both CCK 0.6 and GHK 2.9 were located adjacent to gravel roads, and the site on Clear Creek (CCK 0.6) was about $300 \mathrm{~m}$ downstream of a road crossing. The site on Pinhook Branch (PHK 1.4) is in a young, managed loblolly pine forest; many young and dense growths of honeysuckle border much of the site, indicating recent disturbance. The remaining reference site, BTK 0.3, is located on a tributary (NT14) of Bear Creek in a pine-hardwood forest. Like some other sites, a gravel road parallels the stream along inuch of its length.

Except for BCK 11.09 and BCK 12.36, the substrate at the Bear Creek benthos sites consisted of a relatively homogeneous mixture of rubble, grave1, and sand/fine sediment (Table 2-15). Although the benthos site at BCK 11.09 was dry at the time the substrate analysis was conducted, a mixture of substrate particles similar to that of the lower Bear Creek sites has been observed at this site during the routine benthic invertebrate sampling (J. G. Smith, ORNL/ESD, 1988, personal communication to G. R. Southworth, ORNL/ESD). The substratum at BCK 12.36 was comprised entirely of clay. The percent embeddedness of the dominant particles was less than 58 at BCK 3.25 and increased upstream to more than 758 at BCK 12.36 (Tables 2-11 and 2-15). Embeddedness was near 508 (rating -3.0 ) at two intermediate sites (BCK 7.87 and BCK 9.91).

Like the majority of the Bear Creek sites, the reference sites also consisted of a fairly homogenous mixture of rubble, gravel, and sand/fine sediment (Table 2-15). A greater mixture of dominant substrate types was observed at GHK 1.6, WBK 1.0, HCK 20.6, and CCK 0.6; and bedrock vas commra at HCK 20.6 and CCK 0.6. Plant detritus and large woody debris were found infrequently at GHK 1.6 and WBK 1.0 . Al.though embeddedness varied considerably between reference sites, it was generally less than 258 . Only PHK 1.4 had a rating below four (i.e., more than 258 of the dominant particles were covered by fine sediment.)

Mean current velocities varied considerably both between and within the benthic invertebrate sampling sites on Bear Creek and the reference strearns (Table 2-14). The highest mean velocity in Bear, reek was 
measured at $B C K 3.25(0.14 \mathrm{~m} / \mathrm{s})$. Upstream of this site, velocities dropped considerably; the mean velocity ranged from $0.0 \mathrm{~m} / \mathrm{s}$ at $B C K 11.83$ where tinere was no measurable flow to $0.08 \mathrm{~m} / \mathrm{s}$ at $\mathrm{BCK} 9.40$. One reference ite was dry (GCK 2.4) and two had no measurable flow (BTK 0.3 and GHK $29 \%$ The mean velocity at the remaining reference sites ranged from $0.01 \mathrm{~m} / \mathrm{s}$ at GHK 1.6 and PHK 1.4 to $0.17 \mathrm{~m} / \mathrm{s}$ at HCK 20.6 , the only reference site where the mean velocity exceeded $0.07 \mathrm{~m} / \mathrm{s}$.

Aquatic vegetation was relatively unimportant ai most Bear Creek and reference sites. Sma11, highly localized mats of algae occurred at BCK 3.25, and a1though algae were not observed at BCK 12.36 at the time of the habitat analyses, extensive mats of filamentous algae have been periodically observed (J. G. Smith, ORNL/ESD, personal observation). Small amounts of watercress were found at two reference sites (MBK 1.6 and PHK 1.4), and moss was especially abundant at CCK 0.6 .

\section{3 .4 Discussion}

The initial characterization survey of Bear Creek provided data on substrate and cover variables for low-flow periods. Consequently, comparisons between sites are limited, and the importance of habitat differences may change under other flow conditions.

The relationship of fish populations to available habitat has been examined from many perspectives. Gorman and Karr (1978) helped establish the relationship between fish community complexity and physical habitat, such as stream depth, bottom type, and current velocity. Angermeier and Karr (1984) compared fish abundance with the amount of woody debris in streams. The role of large substrate, undercut banks, and aquatic vegetation in determining population characteristics of smallmouth bass and rock bass was examined by McClendon and Rabeni (1987). The influence of other environmental variables, such as temperature (Baltz et al. 1987) and reguli, ted streamflows (Bain et al. 1988), on microhabitat selection and fish community structure has been found to be significant. Thus, in any study evaluating the effects of remedial actions, it is important to consider the effect of habitat differences on fish community structure.

Considerable differences in habitat structure were found between the fish sampling sites. Although the initial selection of sites aimed at an equal representation of pools and rittles at eacin site, the 1988 
habitat survey showed considerable variation in $P / R$ ratios among the Bear Creek sites (Table 2-13). Lower sites had a coarser, more heterogeneous substrate than the upper sites, especially $\mathrm{BCK} 11.09$ and BCK 11.83. The degree of embeddedness was also lower at BCK 3.25 compared to most sites on upper Bear Creek. Finally, the sites below BCK 9.91 are located in a more mature, less disturbed forest that provides a greater riparian canopy than at the sites in upper Bear Creek.

Despite efforts to match similar habitat variables at all study sites, there were substantial differences among sites due to the longitudinal gradient in physical habitat that is characteristic of streams. Major differences in most physical habitat parameters were observed between upper and lower Bear Creek. Fish species diversity and abundance have been shown to vary as a function of some of the habitat characteristics that differ between upper and lower Bear Creek, such as the amount of siltation and the frequency of no-flow conditions (Foltz 1982). However, the similarity in physical habitat between GCK 2.4 and upper Bear Creek and between MBK 1.6 and lower Bear Creek can be used to identify temporal changes in fish species abundance and richness that are associated with remedial actions implemented at the Y-12 Plant. 


\section{TOXICITY MONITORING}

\subsection{INTRODUCTION}

Data acquired from the Biological Monitoring and Abatement Programs at the Y-12 Plant (for EFPC), the Oak Ridge Gaseous Diffusion Plant (Mitchell Branch), and ORNL (White Oak Creek and its tributaries) have generally shown good correspondences between (1) patterns of ambient toxicity; (2) the structure of biotic communities (invertebrates and fish); (3) water quality factors, such as alkalinity, hardness, conductivity, and $\mathrm{pH}$; and (4) toxicants, such as free and total residual chlorine (J. M. Loar, ORNL/ESD, and J. G. Smith, ORNL/ESD, 1988, personal communication to G. R. Southworth, ORNL/ESD). These findings suggest that tests to quantify toxicity of ambient waters may be a costeffective means to estimate the effects of contaminants on stream communities. Such tests may also provide the first quantifiable evidence for improvements in the biological quality of the water, because the recovery of biotic communities can be slow if the immigration rates of the colonizing species are low or if the availability of resources needed to sustain arriving immigrants is inadequate (MacArthur 1972; Diamond 1975).

Toxicity testing as a means to evaluate biological quality of ambient waters is gaining wider acceptance for the reasons given above. Such tests, however, may not accurately reflect the biological quality of conditions in a stream if dynamic factors are important, such as changes in flow regimes (and therefore toxicant concentrations) or interactions between thermal regimes and toxicity. In such cases, in situ tests using stream organisms will likely provide more accurate assessments of biological conditions. The results of toxicity tests of Bear Creek water and of in situ tests in Bear Creek based on the survival and behavior of a fresh-water snail common in other headwater streams on the Department of Energy's ORR are included in this report to help characterize conditions in this stream. 


\subsection{MATERIALS AND METHODS}

\subsubsection{Ambient Toxicity Tests}

Water samples collected from various sites in Bear Creek and several of its tributaries and from Grassy Creek, a nearby reference stream, were tested for toxicity with fathead minnow (Pimephales promelas) larvae seven times from June 1984 through April 1986. Water samples from six sites in Bear Creek were also tested for toxicity simultaneously with a microcrustacean (Ceriodaphnia dubia) and fathead minnow larvae during March 10-17, 1988, and during April. 27-May 4, 1989. In the April 27-May 4 test, water from $\mathrm{BCK} 12.36, \mathrm{BCK} 11.83$, and BCK 11.09 were tested both at full-strength and at various dilutions; water from $\mathrm{BCK} 9.91, \mathrm{BCK} 9.40$, and $\mathrm{BCK} 7.87$ were tested only at full. strength. The minnow and microcrustacean tests are both EPA-approved, 7-d tests that are designed to provide estimates of chronic toxicity (Horning and Weber 1985). The minnow test quantifies toxicity in terms of reductions in survival and growth of larvae relative to controls (i.e., larvae reared in water lacking contaminants at toxic concentrations). The Ceriodaphnia test quantifies toxicity by statistically detecting reductions in survival and fecundity (i.e., the number of offspring per surviving female) relative to controls. The fathead minnow and Ceriodaphnia 7 -day static-renewal toxicity tests are described in detail in Horning and Weber (1985).

For each test, water from stream sites was collected in 2-gal Nalgene ${ }^{R}$ containers. The samples, which were transported to the laboratory within $2 \mathrm{~h}$ after being collected, were used without filtration or other pretreatment. In tests initiated in 1984 on June 6, July 11, and October 10 and in 1985 on April 10 and June 26, water samples collected from each site on the first day of the test were used as daily replacement water for the entire 7 -day test period. These samples were stored at $7^{\circ} \mathrm{C}$ in a refi igerator and warmed to $25^{\circ} \mathrm{C}$ before use each day. Tests initiated on October 22, 1985; April 10, 1986; March 10, 1988; and April 17, 1989 used water that was collected fresh daily from each site.

Freshly collected samples were, in each case, analyzed for $\mathrm{pH}$ and specific conductivity in the laboratory. The $\mathrm{pH}$ was determined with an 
Orion ${ }^{\mathrm{K}}$ model 811 meter equipped with a temperature-compensated combination electrode; conductivity was measured using a YSI model 32 salinity-conductivity-temperature meter. Samples collected daily for tests were also analyzed for alkalinity by potentiometric titration with standard HCl solution (EPA method 130.1) and for hardness by titrations with ethylenediamine tetracetic acid (EPA method 130.2).

\subsubsection{In Situ Snail Tests}

In situ tests at four sites on Bear Creek (BCK 12.36, BCK 9.40, BCK 7.87, and BCK 5.15) were conducted using the operculate snail, Elimia (Goniobasis) clavaeformis Lea. In some experiments, snails were caged in plexiglass cylinders, the ends of which were covered $w$ th netting to prevent their escape. In these experiments, the animals did not have access to food. At each site, four replicate cylinders, each containing 10 snails, were positioned parallel to the direction of flow so the animals were exposed to hater but prevented from coming into direct contact with the sediments. Seven such expeximents with caged snails, with each lasting from 7 to $30 \mathrm{~d}$, were conducted from August 1986 through January 1987. In these experiments, snails were categorized as unharmed, stressed (foot extended, immobilized, but alive), or moribund (dead or nonresponsive to probing). Snails were similarly caged at a noncontaminated reference site (upper White Oak Creek) to serve as controls in each experiment. Representative specimens from some of the experiments were digested with perchloric acid and analyzed for selected metals. Entire snails were used for this purpose because the epithelium of a snail shell can also take up metals that may adversely affect shell development. Metal contents (expressed as $\mu \mathrm{g}$ of metal per gram dry weight of snail) were determined either by inductively coupled plasma scans or by atomic absorption (for cadmium).

In another series of experiments conducted in December 1986 and January and February 1987, three replicate plastic trays containing natural cobble substrates and 100 snails each from upper White Oak Creek were placed in the same four sites in Bear Creek (Figs. 1-1 and 1-2). The snails in these experiments had access to uncontaminated natural food and could readily crawl out of the trays and contact the Bear Creek sediments. Twenty-four or $48 \mathrm{~h}$ after being placed in the stream, the 
net distance and direction (upstream or downstream) each snail had moved was recorded. The condition of the animals (alive, stressed, or dead, as defined above) was also noted. These experiments were used to evaluate snail movement patterns at sites with different levels of contamination. The percentage of animals stressed or dead at each site is assumed to reflect the degree of acute toxicity.

\section{3 DATA ANALYSIS}

\subsubsection{Ambient Toxicity Tests}

The fathead minnow test used 4 replicates of 10 larvae each to assess the toxicity of each water sample. Mean survival, expressed as percent, at the end of the test was computed using all four replicates. Survival values over the 7-d test period were transformed (arc-sine square root) before statistical analyses were performed. Because the SD computed from transformed data should not be untransformed (Steel and Torrie 1960), the variance in toxicity about the means for sites or dates was expressed as the coefficient of variation, or CV, ( = SD/mean $\times 100$ ) based on the arc-sine square-root transformed data.

Statistical analysis of the ambient toxicity data was accomplished using the Statistical Analysis System (SAS)-GLM (General Linear Mode1) analysis of variance (ANOVA), which is recommended for unbalanced designs, Data from the fish test were analyzed in two ways. First, a one-way ANOVA was used to analyze the data on a test-by-test basis. When followed by Dunnett's test, this procedure identified sites with significant levels of toxicity relative to the controls. Second, a two-way ANOVA was performed using data fur the eight sampling dates and the nine Bear Creek sampling sites ( $8 \times 9$ matrix; Table 3-1). This procedure identified the amount of variance attributable to sampling site, to sampling date, and to interactions between these two factors. The 7-d fathead minnow test has two endpoints: survival and growth (increase in dry weight). Data for each of these endpoints were analyzed using the GLM procedures described above. Survival and fecundity of Ceriodaphnia was analyzed using Fisher's Exact Test and SAS-GLM followed by Dunnett's one-sided test, respectively. No transformations were needed for data on Ceriodaphnia survival because 
Table 3-1. Schodule used to ovaluate mblemt toxioity of water from Bear Creak and aelected tributaries with lathead annow larvae. BCX - Bear Creck. The numbers followins the 1etter code indicate the distance (km) upatreas. WT4, Mr7, Frs and nT1 axe tributaries of Bear Croak east of Route 95 (F18s. 1-1 and 1-2). GCK = Grassy ireek (a reference stream).

Square brackets ldentify abiguous test outcomen due to unacceptably high within-test variability. Dashes Indicate that no test was pirformed

\begin{tabular}{|c|c|c|c|c|c|c|c|c|c|}
\hline \multirow[b]{2}{*}{$\begin{array}{l}\text { Sampling } \\
\text { site }\end{array}$} & \multicolumn{9}{|c|}{ Inttial date of test } \\
\hline & $6 / 6 / 84$ & $7 / 11 / 84$ & $10 / 10 / 84$ & $4 / 10 / 85$ & $6 / 26 / 85$ & $10 / \pi 2 / 85$ & $4 / 10 / 86$ & $3 / 10 / 88$ & $4 / 27 / 89$ \\
\hline BCK 12.36 & $x$ & $\mathbf{x}$ & $x$ & $x$ & $x$ & $\mathrm{x}$ & $\mathbf{x}$ & $\mathbf{x}$ & $x$ \\
\hline BCK 11.83 & $\mathbf{x}$ & $\mathbf{x}$ & $x$ & $\mathbf{x}$ & --- & $x$ & $x$ & $x$ & $x$ \\
\hline BCK 11.09 & $\mathbf{x}$ & $\mathbf{x}$ & $x$ & $x$ & $\mathbf{x}$ & $\mathrm{x}$ & $x$ & $x$ & $\mathrm{x}$ \\
\hline $\operatorname{BCK} 10.32$ & $\mathbf{x}$ & $x$ & $\cdots$ & $\mathbf{x}$ & $x$ & $\mathbf{x}$ & $\mathbf{x}$ & $-\cdots$ & --- \\
\hline BCK 9.91 & $x$ & $x$ & $x$ & $x$ & $\mathbf{x}$ & $x$ & $x$ & $x$ & $x$ \\
\hline BCK 9.40 & $\mathrm{x}$ & $x$ & $x$ & $x$ & $x$ & $x$ & $x$ & $x$ & $x$ \\
\hline BCK 7.87 & $\cdots$ & $\mathrm{x}$ & $x$ & $x$ & $-\cdots$ & $x$ & $x$ & $x$ & $\mathrm{x}$ \\
\hline BCK 5.15 & $\cdots$ & $x$ & $x$ & {$[X]$} & -- & {$[X]$} & $x$ & --- & $\cdots$ \\
\hline BCK 3.25 & -- & --- & $x$ & {$[\mathrm{X}]$} & $-\cdots-$ & {$[x]$} & $x$ & $-\cdots$ & $-\cdots$ \\
\hline NT 4 & -- & $-\cdots$ & $x$ & {$[X]$} & --- & -- & --- & -- & $\cdots$ \\
\hline NT7 & $\cdots$ & --- & $x$ & $x$ & -- & $\cdots$ & $x$ & $-\infty$ & $-\cdots$ \\
\hline NT 8 & $\cdots$ & -- & $x$ & {$[x]$} & $x$ & --- & $x$ & $\ldots$ & $\cdots$ \\
\hline NT 14 & $\cdots$ & --- & $\cdots$ & {$[x]$} & $\ldots$ & $-\cdots$ & -- & -- & $--\cdots$ \\
\hline GCK 2.4 & $x$ & $x$ & $x$ & $-\cdots$ & $\cdots$ & $x$ & $-\cdots$ & --- & -- \\
\hline GCK 1.4 & $x$ & $x$ & $x$ & $-\cdots$ & $\ldots$ & $x$ & $\ldots$ & $\cdots$ & $\ldots$ \\
\hline
\end{tabular}


the 10 individual animals used to determine toxicity for each water sample served as replicates.

Toxicity data for tributaries of Bear Creek (NT4, NT7, NT8, and NT14) were not included in the analysis described above; none of the tributaries was tested more than four times. The presence of significant levels of toxicity at these sites was determined by comparing survival (arc-sine square-root transformed) of fathead minnow larvae in stream water to their survival in dechlorinated tap water, using Dunnett's test (one-sided, with alpha $=0.05$; steel and Torrie 1960, p. 111).

Grassy Creek was used as a reference site. It is a tributary of the Clinch River and, because of its location and biotic diversity (Tables $1-2$ and $1-3$ ), was expected to have minimal toxicity. Two sites (GCK 2.4 and GCK 1.4) were sampled on each of four dates (Table 3-1). As above, mean survival of the fathead minnow larvae was computed for each Grassy Creek test after transforming the data. On each of the four. test dates, survival of the larvae in water fxom each of the two Grassy Creek sites was compared statistically to the survival of larvae in control. water, using Dunnett's test as described above. A paired, onesided t-test with alpha $=0.05$ was used to determine if toxicity at GCK 1.4 and GCK 2.4 was significantly different.

The data from the tests conducted during April 27-May 4, 1989, were analyzed differently from those obtained from earlier tests because the tests in 1989 included a dilution series for some sites (e.g., 1008, 608,408 , and $20 \%$ for water from BCK 1.2.36). The results of the Ceriodaphnia test in 1989 were interpreted using Fisher's Exact Test (to detect differences in survival relative to the control) and GLM followed by Dunnett's test (to detect differences in reproduction of the animals in full-streng,th water from various sites). On1y summary statistics were used for the fathead minnow test results in this test period because in 11 of 12 cases the mean growth of the fish in Bear Creek water (diluted or full strength) was equal to or exceeded growth of fish in the control. Thus, the use of hypothesis-testing statistics to compare responses of fish in ambient waters from Bear Creek to those of fish in the controls was deemed inappropriate. However, mean growth of 
the fish in full-strength water from the six sites appeared to increase slightly, but systematically, with distance downstream.

Conductivity and $\mathrm{pH}$ data were, in most cases, evaluated using only descriptive statistics (means, variances, or CV). A strong downstream decrease in conductivity was apparent in Bear Creek between BCK 12.36 and BCK 3.25 on sampling dates in 1984 through 1989. Thus, relationships between the distance $(\mathrm{km})$ downstream from site BCK 12.36 and conductivity were evaluated by correlation using conductivity data untransformed and transformed (either square root or $\log _{10}$ ).

\subsubsection{In Situ Snail Tests}

Unlike the ambient toxicity tests that assessed responses of animals of known quality and age to water under controlled conditions, the in situ tests used snails of unknown history collected at different times from a naturally varying habitat. These latter tests evaluated responses of the animals to a composite of conditions, including differences in season, water temperature, flow regimes, chemical composition, and (in some experiments) substrate type and food. Consideration of these factors and that the in situ test was designed primarily to determine the potential utility of Elimia as a species that could be used for in situ tests, argued against the use of rigorous hypothesis-testing statistical tests. Instead, only the sample mean is used to summarize the results of the in situ snail tests, thus minimizing the risk that readers will make firm and unwarranted conclusions about cause and effect. More detailed information on the in situ tests, including a discussion of their uses and limitations, is given in Burris (1987) and Burris et a1. (1990).

\subsection{RESULTS}

\subsubsection{Ambient Toxiclty Tests}

Results of the fathead minnow larvae toxicity tests of water from nine Bear Creek sites are summarized in Tables 3-2 and 3-3. Water from BCK 12.36 markedly reduced survival of the larvae in six of eight tests; evidence of toxicity at other Bear Creek sites was always less consistent and typically less pronounced. 


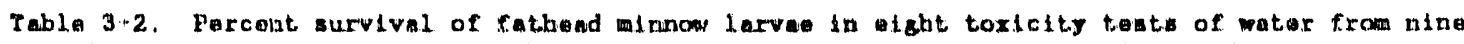

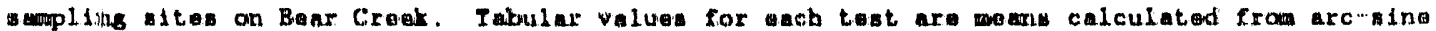
nquare-root transformed values (n = in anch caso). The ovarell imitransformed moen wurvival at ench wite is wum in the colum on the right. Asterisk designate tust.s with survival

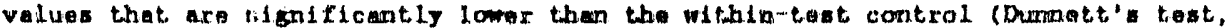
$p<0.05)$. CV $=$ Coefeiciont variation

\begin{tabular}{|c|c|c|c|c|c|c|c|c|c|c|}
\hline \multirow[b]{2}{*}{ Site } & \multicolumn{9}{|c|}{ Testa } & \multirow[b]{2}{*}{ (CV) } \\
\hline & 1 & 2 & 3 & 4 & 5 & 6 & 7 & 8 & Mean & \\
\hline Controlb & 8.5 .4 & 85.4 & 81.7 & 80.0 & 65.6 & 90.0 & 60.6 & 90.0 & 97.6 & $(14.3)$ \\
\hline $\mathrm{BCK} \quad 12.36$ & $37.8 *$ & $0.0 *$ & $11.3 \star$ & 85.4 & $4.8 *$ & $4,8 *$ & $24.2 *$ & 71.6 & 2.4 .9 & $(108.9)$ \\
\hline BCK 21.83 & 63.8 & $5 \% .5 \mathrm{~m}$ & 73.8 & 80.0 & $\cdots \cdots$ & 90.0 & 56.0 & 80.9 & 82.6 & $(19.8)$ \\
\hline BCK 11.09 & $45.7 \%$ & 58.0 & 77.2 & 8.5 .4 & $34.1 *$ & 80.0 & 53.8 & 80.8 & 78.9 & $(33.3)$ \\
\hline $\operatorname{BCK} \quad 20.32$ & $50.2^{*}$ & 76.0 & $\cdots .$. & 90.0 & 61.2 & 90.0 & 62.9 & $\cdots$ & 81.5 & $(21.0)$ \\
\hline BCK 9.91 & $50.2 *$ & $59.2^{*}$ & 90.0 & 80.8 & 51.8 & 76.2 & 70.4 & 80.9 & 88.2 & $(22.1)$ \\
\hline BCK 9.40 & $5.5 .7 *$ & 76.7 & 78.8 & 80.0 & 58.8 & 83.4 & 50.8 & 80.9 & $\theta 1.2$ & $(18.5)$ \\
\hline BCK 7.87 & $\cdots$ & $33.2 *$ & 68.8 & 85.4 & $\cdots$ & $48.6 *$ & 62.1 & 77.1 & 83.3 & $(21.4)$ \\
\hline$B C K=15$ & $\cdots \cdots$ & 45.64 & 85.4 & $59.5^{\circ}$ & $\ldots$ & $42.0 * c$ & 55.8 & $\ldots$ & 79.7 & $(28.1)$ \\
\hline$B C K \quad 3.25$ & $\cdots$ & $\ldots-$ & 67.4 & $33.7 \mathrm{n}^{\circ}$ & $\cdots$ & $57.5 *$ & 58.1 & $\ldots$ & 70.2 & $(28,1)$ \\
\hline
\end{tabular}

Arest initiacion dates were $5 / 6 / 84,7 / 11 / 84,10 / 10 / 84,4 / 10 / 84,6 / 26 / 85,10 / 22 / 85,4 / 10 / 86$, and $3 / 10 / 88$ for lests 1 through 8 , respectively.

bCont:ol water was dechlorinated tap wates, oxcept test 8 In which degassed diluted mineral water was used.

Within-test variability was high :SD $\geq 25 \%$, transformad percent survival). Such tests may not. be valid. Then survival values for these four tasts were oxcluded from the GLA two-way ANova, the overall. F value increased substantially (from 9.46 to 1B.27). F valuos for site and date factors also increased (from 8.21 to 50.30 and fram 21.14 to 47.12 for ste and date, respectivaly). For all factors, $p<0.0001$ regardless of whethor these four tests were usad in the anelysis.

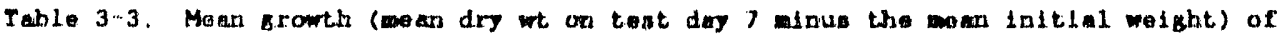

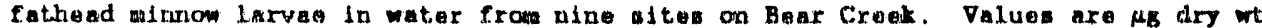
per IIsh

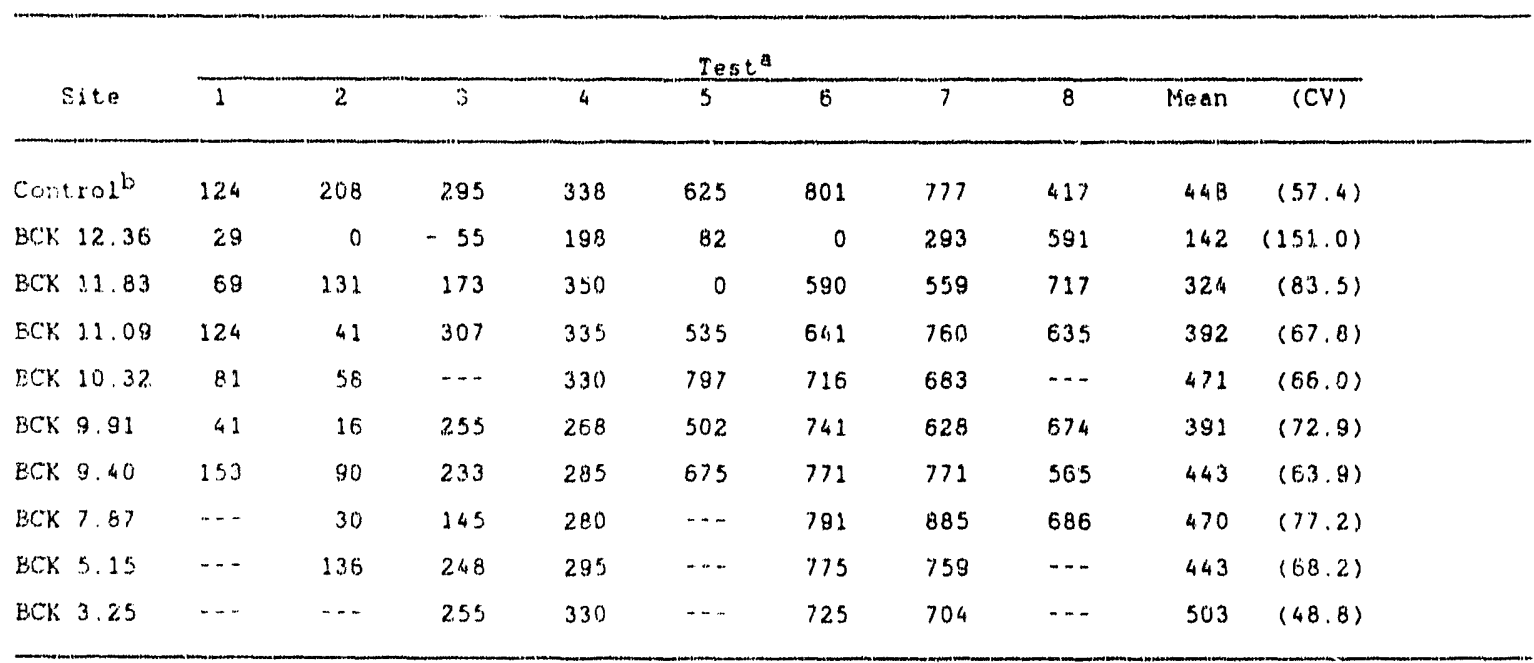

\footnotetext{
a Test initiation dates are $6 / 6 / 84,7 / 11 / 84,10 / 10 / 84,4 / 10 / 85,6 / 26 / 85,10 / 22 / 85$, $4 / 10 / 86$, and $3 / 10 / 88$ for tests 1 through 8 , respoctively.

${ }^{b}$ Control water is dechlorinated tap watex, axcept test. 8 in whlch degassod diluted mineral waker was used.
} 
The results of the GLM two-way ANOVA (by date and site) using transformed data on percent survival of fish larvae at sites $B C K$ 12.36, BCK 11.83, BCK 11.09, BCK 10.32, BCK 9.91, BCK 9.40, BCK 7.87, BCK 5.15, and BCK 3.25 are shown in Table 3.4. Date and site effects both contributed substantially to the total variance ( $F$ values for site and date were 21.24 and 27.55 , respectively); there was also a smaller but statistically significant interaction between date and site $(F=3,65$, df $=39 ; p<0.0001)$.

The results of the eight tests of Grassy Creek water are shown in Table 3-5. On all four sampling dates, GCK 1.4 water appeared more toxic than water collected from GCK 2.4. The probability of this outcome due to chance alone is $0.5^{4}=0.06$, which only slightly exceeds the usually accepted significance level of 0.05 . The $t$ statistic calculated in comparing toxicity of upstream and downstream Grassy Creek sites was 2.34 ( $p=0.058$, df -3 ), which again only marginally exceeds the level normally used to designate statistical significance.

Water from BCK 1.2 .36 and BCK 11.83 reduced survival of Ceriodaphnia in the test conducted during March 1.0-17, 1988. Water from BCK 12.36 was toxic at 100,60 , and 408 but not at 208 of full strength. Water from BCK 11.83 was toxic at 1008 and 708 but not at 308 of full strength (Table 3-6). In water where Ceriodaphnia survival was $\geq 608$, there was no evidence of reduced fecundity, suggesting that acute toxicity was more important than chronic toxicity in upper Bear Creek.

The results of the fathead minnow and Ceriodaphnia tests conducted during April 27-May 4, 1989, area shown in Tables 3-7 and 3-8, respectively. Based on survival, the minnow tests showed little evidence for toxiclty at any of the sites that were tested. ANOVA for the growth of the fish among the six sites, however, showed highly significant differences $\left(p<0.0001, F_{5,23}=12.35\right.$, with the overal1 model of the effects of site on growth accounting for 77.48 of the variation). Based on Duncan's test, growth of the fish in full-strength water from BCK 7.87 was significantly higher than their growth in fullstrength water from any other: site, and there was a good general progression of lower growth with distance upstream (Table 3-7). 
Table 3-4. Results of two way ANOVA (GLM) for survival and growth of fathead minnow larvae in toxicfty tests of water from various sites in Bear Creek. Factors are blocked by site (BCK 12.36, BCK 11.83, BCK 11.09, BCK 10.32, BCK 9.91, 8CK 9.40, BCK 7.87, BCK 5.15 and BCK 3.25$)$ and date of test initiation $(6 / 6 / 84,7 / 11 / 84$, $10 / 10 /-84,4 / 10 / 85,6 / 26 / 85,10 / 22 / 85$, and $4 / 10 / 86)$.

Each cell contalned four replicates

\begin{tabular}{|c|c|c|c|c|c|}
\hline $\begin{array}{l}\text { Source of } \\
\text { variation }\end{array}$ & $\begin{array}{l}\text { Sum of } \\
\text { squares }\end{array}$ & $\begin{array}{l}\text { Mean } \\
\text { square }\end{array}$ & df & $F^{\prime}$ & $\begin{array}{l}\text { Probability } \\
\text { of }>F\end{array}$ \\
\hline \multicolumn{6}{|c|}{ Survival } \\
\hline Model & 42.71 & 0.806 & 53 & 8.78 & 0.0001 \\
\hline Date & 15.1 & .. & 6 & 27.55 & 0.0001 \\
\hline Site & 15.59 & $\ldots$ & 8 & 21.24 & 0.0001 \\
\hline Date $x$ Site & 13.05 & $\cdots$ & 39 & 3.65 & 0.0001 \\
\hline Error & 14.87 & 0.092 & 162 & $\ldots$ & $\ldots$ \\
\hline Tota1 & 57.58 & $\cdots$ & 215 & $\ldots$ & $\ldots$ \\
\hline \multicolumn{6}{|c|}{ Growth } \\
\hline Model & 15.06 & 0.295 & 51. & 44.11 & 0.0001 \\
\hline Date & 12.06 & $\ldots$ & 6 & 300.12 & 0.0001 \\
\hline Site & 1.03 & $\ldots$ & 8 & 19.23 & 0.0001 \\
\hline Date $\times$ Site & 1.01 & $\cdots$ & 37 & 4.07 & 0.0001 \\
\hline Error & 0.98 & 0.067 & 147 & $\ldots$ & $\ldots$ \\
\hline Total & 16.05 & $\ldots$ & 198 & $\ldots$ & $\ldots$ \\
\hline
\end{tabular}

aType III sum of squares, as described in SAS (1982a), p. 165. 
Table 3-5. Percent survival of fathead minnow larvae tested with water collected from two sites in Grassy creek. Tabular values are untransformed means ( $n-4$ ) computed using axc-sine square root transformed percentages. Control values are the percent survival of fathead minnow larvae in dechlorinated tap water. Asterisks

designate values significantly

different from survival in control water using a one-sided Dunnett's test $(p<0.05)$

\begin{tabular}{llrcc}
\hline & \multicolumn{3}{c}{ Starting Date of Toxicity Test } \\
\cline { 2 - 3 } & $6 / 6 / 84$ & $7 / 11 / 84$ & $10 / 10 / 84$ & $10 / 22 / 85$ \\
\hline Contro1 & 98.0 & 97.5 & 95.9 & 100.0 \\
GCK 2.4 & $64.5 *$ & $79.2 *$ & 97.4 & 97.4 \\
GCK 1.4 & $56.6 *$ & $5.9 *$ & 88.9 & $59.0 *$ \\
\hline
\end{tabular}


Table 3-6. Number of Ceriodaphnia survivors and their fecundity (mean number of offspring per female, \pm SD) in water from various Bear Creek sites. Test was conducted during March 10-17, 1988. Controls were reared in and dilutions were prepared with degassed, diluted mineral water. Asterisks designate values that are significantly different from the control. (Fisher's Exact Test, $p<0.05$ )

\begin{tabular}{|c|c|c|c|c|c|}
\hline \multirow{2}{*}{$\begin{array}{l}\text { Site } \\
\text { BCK }\end{array}$} & \multicolumn{2}{|c|}{ Concentration } & \multirow{2}{*}{$\begin{array}{l}\begin{array}{l}\text { Number of } \\
\text { Replicates }\end{array} \\
10\end{array}$} & \multirow{2}{*}{$\frac{\text { Mean survival }}{0 *}$} & \multirow{2}{*}{$\begin{array}{c}\text { Fecundity } \\
\ldots \pm \ldots\end{array}$} \\
\hline & 12.36 & 1008 & & & \\
\hline $\mathrm{BCK}$ & 12.36 & 608 & 10 & $0 *$ & $\ldots \pm \ldots$ \\
\hline BCK & 12.36 & 408 & 10 & $2 *$ & $11.5 \pm 0.7$ \\
\hline BCK & 12.36 & 208 & 10 & 7 & $16.0 \pm 4.6$ \\
\hline$B C K$ & 11.83 & 1008 & 10 & $2 *$ & $16.0 \pm 4.2$ \\
\hline BCK & 1.1 .83 & 708 & 10 & $3 *$ & $18.3 \pm 1.5$ \\
\hline $\mathrm{BCK}$ & 11.83 & 308 & 10 & 8 & $18.8 \pm 5.4$ \\
\hline BCK & 10.75 & 1008 & 10 & 7 & $20.4 \pm 4.2$ \\
\hline $\mathrm{BCK}$ & 10.75 & 508 & 10 & 10 & $20.9 \pm 3.7$ \\
\hline $\mathrm{BCK}$ & 9.91 & 1008 & 10 & 6 & $22.7 \pm 2.7$ \\
\hline $\mathrm{BCK}$ & 9.40 & 1008 & 10 & 8 & $19.8 \pm 4.4$ \\
\hline BCK & 7.87 & 1008 & 10 & 8 & $18.8 \pm 4.5$ \\
\hline CONT & CROL & 1008 & 10 & 9 & $20.2 \pm 1.4$ \\
\hline
\end{tabular}


Table 3-7. Mean survival and mean growth (mean dry wt on test day 7 minus the mean initial wt \pm SD) of fathead minnow larvae in water from six sites in Bear Creek. The test initiation date was Apri1 27, 1989

\begin{tabular}{lccc}
\hline Site & Concentration & $\begin{array}{c}\text { Mean survival } \\
\text { (percent) }\end{array}$ & $\begin{array}{c}\text { Mean growth } \\
\text { (mg/fish } \pm \text { SD })\end{array}$ \\
\hline BCK 12.36 & 1008 & 92.5 & $0.37 \pm 0.03$ \\
BCK 12.36 & 608 & 90.0 & $0.43 \pm 0.04$ \\
BCK 12.36 & 408 & 97.5 & $0.43 \pm 0.05$ \\
BCK 12.36 & 208 & 97.5 & $0.42 \pm 0.02$ \\
BCK 11.83 & 1008 & 67.5 & $0.34 \pm 0.06$ \\
BCK 11.83 & 708 & 100.0 & $0.40 \pm 0.02$ \\
BCK 11.83 & 308 & 57.5 & $0.54 \pm 0.14$ \\
BCK 11.09 & 1008 & 67.5 & $0.42 \pm 0.03$ \\
BCK 11.09 & 508 & 82.5 & $0.47 \pm 0.03$ \\
BCK 9.91 & 1008 & 82.5 & $0.44 \pm 0.05$ \\
BCK 9.40 & 1008 & 85.0 & $0.52 \pm 0.06$ \\
BCK 7.87 & 1008 & 90.0 & $0.54 \pm 0.03$ \\
Contro1 & & 100.0 & $0.37 \pm 0.03$ \\
\hline
\end{tabular}

${ }^{a}$ Control water is degassed diluted mineral water. 
Table 3-8. Number of Ceriodaphnia survivors and their fecundity (mean number of offspring per female, $\pm S D$ ) in water from various Bear Creek sites. Test was conducted during Apr11 27-May 4,1989.

Controls were reared in and dilutions prepared whth degassed, diluted mineral water. Asterisks in the survival column show survival values for any samples (full-strength or diluted) that are significantly $(p<0.05)$ lower from the control based on Fisher's Exact Test; the asterisks in the fecundity column show, for full-strength water only, fecundity values that are significantly $(p<0.05)$ lower than the control based on analysis of variance followed by Dunnett's test

\begin{tabular}{lcccc}
\hline Site & Concentration & $\begin{array}{c}\text { Number of } \\
\text { replicates }\end{array}$ & Survival & Fecundity \\
\hline BCK 12.36 & 1008 & 10 & $0^{*}$ & $\ldots \ldots \pm \ldots$ \\
BCK 12.36 & 608 & 10 & $0^{*}$ & $\ldots \ldots \pm \ldots$ \\
BCK 12.36 & 408 & 10 & $1^{*}$ & $\ldots \ldots \pm \ldots$ \\
BCK 12.36 & 208 & 10 & $1^{*}$ & $\cdots$ \\
BCK 11.83 & 1008 & 10 & $0^{*}$ & $\ldots \ldots \pm \ldots$ \\
BCK 11.83 & 708 & 10 & $0^{*}$ & $\cdots$ \\
BCK 11.83 & 308 & 10 & 6 & $14.8 \pm 2.8$ \\
BCK 11.09 & 1008 & 10 & $5^{*}$ & $13.4 \pm 5.9^{*}$ \\
BCK 11.09 & 508 & 10 & $3^{*}$ & $21.0 \pm 1.7$ \\
BCK 9.91 & 1008 & 10 & 6 & $15.2 \pm 2.8^{*}$ \\
BCK 9.40 & 1008 & 10 & 8 & $13.4 \pm 5.1^{*}$ \\
BCK 7.87 & 1008 & 10 & 7 & $18.7 \pm 3.8$ \\
Contro1 & & 10 & 10 & $21.3 \pm 4.5$ \\
\hline
\end{tabular}


Water from the three sites farthest upstream ( $B C K$ 12.36, BCK 11.83, and BCK 1.1.09) was acutely toxic to Ceriodaphnia (Table 3-8). Water from BCK 12.36 was particularly problematic, as it was acutely toxic (i.e., it killed a significant proportion of the animals, relative to controls, within $96 \mathrm{~h}$ ) even at 208 of full strength. A dose-response pattern of acute toxicity was also evident with water from BCK 11.83; Ceriodaphnia survived in 308 water but not in the two higher concentrations (Table 3-8). With the Ceriodaphnia test, estinates of chronic toxicity are made by evaluating fecundity. The fecundity data for the control and for the four sites for which fecundity data were available for full-strength water (i.e., BCK 11.09, BCK 9.91, BCK 9.40, and BCK 7.87) showed that three of these sites (BCK 11.09, BCK 9.91, and BCK 9.40) showed evidence for chronic toxicity (Table 3-8). Thus, the Ceriodaphnia test identified a "textbook perfect" trend in ambient toxicity: acute toxic conditions were detected at BCK 12.36 and BCK 11.83; both acute and chronic toxicity were detected at BCK 11.09; chronic toxicity only was detected at BCK 10.32 and $B C K$ 9.91; and no toxicity was detected at BCK 7.87.

A comparison of the results of the Ceriodaphnia tests conducted during March 10-17, 1988, versus those conducted during Apri1 24-May 1989, (Tables 3-6 and 3-8) showed both a major similarity and a major difference. The tests conducted during these two periods were similar in that a marked reduction in toxicity was found with distance downstream from BCK 12.36; the results of the tests from the two periods differed in that during the more recent tests, biological quality of the water in Bear Creek appeared distinctly lower than it was during the earlier tests. This tendency was evident both for survival and fecundity. For example, five statistically significant differences in survival (relative to the control) were detected for Ceriodaphnia in the first test, but in the second test the number of significant differences had increased to eight. Additionally, whereas survival effects were noted only at $B C K 12.36$ and 11.83 in the first test, survival effects were noted at $B C K 12.36, B C K 11.83$, and $B C K 11.09$ in the second set of tests. Similarly, although fecundity of the controls for the two test periods was very similar $(20.2 \pm 1.4$ vs $21.3 \pm 4.5$ offspring per 
surviving female), the overall average fecundity of Ceriodaphnia in ambient waters for identical site-dilution combinations was 20.0 for the tests in 1988 and 15.7 for the tests in 1989.

Although streams more often have positive relationships between conductivity and distance downstream, as discussed in Sect. 2.1.1.2 conductivity of Bear Creek water declined with distance downstream (Tables 3-9,3-10, and 3-11). A negative correlation between mean conductivity for each 7 -d test period and distance ( $\mathrm{km}$ ) downstream of site BCK 12.36 was found on all test dates when conductivity was measured. Values of $\mathrm{r}^{2}$ ranged from -0.73 to -0.99 for the different sampling dates from 1984-1988. When a mean conductivity value averaged over these dates was used for each site, the overall relationship was statistically significant $\left(x^{2}=-0.82 ; \mathrm{df}=5, \mathrm{p}<0.01\right)$. The relationships improved slightly $\left(r^{2}=-0.90\right.$ and $\left.r^{2}=0.95\right)$ when conductivity values were first transformed using square root or $\log _{10}$ functions, respectively.

\subsubsection{In Situ Snail Tests}

The results of the snail studies indicated that the percentage of snails categorized as stressed or dead tended to be higher at sites in upper Bear Creek than those farther downstream. For all caged-snail tests, for example, almost 558 of the snails at BCK 12.36 became stressed, while the percentage that became stressed at sites BCK 9.40 , $\mathrm{BCK} 7.87$, and $\mathrm{BCK} 5.15$ was 18,19 , and $<108$, respectively. Even at BCK 12.36, however, the test-to-test variability in the fraction of stressed snails was high. A similar trend was observed in the percentage of animals categorized as dead (as above, for all experiments pooled). The percentage of caged snails that died at BCK 12.36, BCK 7.87, BCK 5.15, and $\mathrm{BCK} 3.25$ was $14,4,5$, and 08 , respectively. Snails caged in the noncontaminated reference site in white Oak Creek showed no evidence of stress and had no mortality. Again, the test-totest variability in the percentage of caged snails scored as dead was especially high at $B C K 12.36$, ranging from $<10$ to $>908$ in October and mid-August 1986, respectively. 
Table 3-9. Conductivity $(\mu \mathrm{S} / \mathrm{cm})$ of water collected from various Bear Creek sites. Values are means ( $\pm S D$ ) calculated by averaging the mean values per toxicity test for the first seven tests

\begin{tabular}{ccc}
\hline \multicolumn{1}{c}{ Site } & Conductivity & $\mathrm{N}$ \\
\hline BCK 12.36 & $4,043 \pm 1,457$ & 5 \\
BCK 11.83 & $1,930 \pm 456$ & 4 \\
BCK 11.09 & $1,805 \pm 790$ & 5 \\
BCK 10.32 & $1,192 \pm 457$ & 4 \\
BCK 9.91 & $804 \pm 182$. & 5 \\
BCK 9.40 & $666 \pm 189$ & 5 \\
\hline
\end{tabular}


Table 3*10. Results of the daily chemical analyses conducted for Ceriodaphnia and fathead minnow larvae toxicity test.s of water from six sites in Bear Creak.

Day 1 was on Apri1 27, 1889

\begin{tabular}{|c|c|c|c|c|c|c|c|}
\hline \multirow[b]{2}{*}{ Day } & \multirow[b]{2}{*}{ Site } & \multirow[b]{2}{*}{$\mathrm{pH}$} & \multirow[b]{2}{*}{ Cond. ${ }^{a}$} & \multirow[b]{2}{*}{ Alk, ${ }^{b}$} & \multirow[b]{2}{*}{ Hardness ${ }^{c}$} & \multicolumn{2}{|c|}{ Oxyzen ${ }^{\mathrm{d}}$} \\
\hline & & & & & & New & Old \\
\hline \multirow[t]{7}{*}{1} & Control & 7.37 & 85 & 33.0 & 48 & 8.3 & 8.0 \\
\hline & BCK 12.36 & 7.60 & 1459 & 220.0 & 1000 & 8.3 & 7.7 \\
\hline & BCK 11.83 & 7.77 & 1729 & 177.0 & 1020 & 8.3 & 7.7 \\
\hline & BCK 11.09 & 8.01 & 908 & 151.0 & 42,8 & 8.3 & 7.5 \\
\hline & BCK 9.91 & 7.98 & 72.1 & 165.0 & 340 & 8.3 & 7.6 \\
\hline & BCK 9.40 & 8.00 & 631 & 160.0 & 230 & 8.3 & 7.5 \\
\hline & BCK 7.87 & 8.13 & 498 & 150.0 & 260 & B. 3 & 7.5 \\
\hline \multirow[t]{7}{*}{2} & Control & 7.63 & 85 & 31.0 & $4 ?$ & 8.4 & 7.7 \\
\hline & BCK 12.36 & 7.59 & 2460 & 243.0 & 1220 & 8.3 & 7.6 \\
\hline & BCK 11.83 & 7.86 & 1960 & 190.0 & 920 & 8.2 & 7.6 \\
\hline & BCK 11.09 & 8.05 & 932 & 152.0 & 442 & 8.3 & 7.7 \\
\hline & BCK 9.91 & 7.98 & 722 & 180.0 & 356 & 8.4 & 7.7 \\
\hline & BCK 9.40 & 7.61 & 545 & 155.0 & 274 & 8.4 & 7.6 \\
\hline & BCK 7.87 & 8.12 & 498 & 150.0 & 242 & 8.3 & 7.5 \\
\hline \multirow[t]{7}{*}{3} & Control & 7.99 & 85 & 31.0 & 42 & 8.4 & 7.6 \\
\hline & BCK 12.36 & 7.68 & 2450 & 243.0 & 1100 & 8.4 & 7.5 \\
\hline & BCK 11.83 & 7.89 & 1980 & 189.0 & 920 & 8.4 & 7.7 \\
\hline & BCK 11.09 & 8.09 & 982 & 157.0 & 420 & 8.4 & 7.6 \\
\hline & BCK 9.91 & 8.06 & 735 & 180.0 & 344 & 8.4 & 7.6 \\
\hline & BCK 9.40 & 8.03 & 615 & 163.0 & 286 & 8.4 & 7.5 \\
\hline & BCK 7.87 & 8.18 & 506 & 1.55 .0 & 240 & 8.4 & 7.4 \\
\hline \multirow[t]{7}{*}{4} & Control & 7.62 & 85 & 26.0 & 42 & B. 3 & 8.1 \\
\hline & BCK 12.36 & 7.65 & 2280 & 238.0 & 1120 & 8.3 & 8.1 \\
\hline & $\mathrm{BCX} 12.83$ & 7.84 & 1771 & 182.0 & 880 & 8.3 & 7.3 \\
\hline & BCK 11.09 & B. 05 & 1026 & 153.5 & 430 & 8.3 & 7.9 \\
\hline & BCK 9.91 & 8.00 & 748 & 175.0 & 346 & 0.3 & 7.8 \\
\hline & BCK 9.40 & 7.99 & 619 & 157.0 & 266 & 8.3 & 7.6 \\
\hline & BCK 7.87 & 8.14 & 510 & 150.0 & 240 & 8.3 & 7.5 \\
\hline \multirow[t]{7}{*}{5} & Control & 7.63 & 85 & 27.0 & 46 & 8.4 & 8.1 \\
\hline & BCK 12.36 & 7.80 & 1.184 & 94.0 & 530 & 7.9 & 8.0 \\
\hline & BCK 11.83 & 7.76 & 771 & 94.0 & 358 & 8.2 & 8.0 \\
\hline & BCK 11.09 & 7.94 & 886 & 126.0 & 356 & 8.0 & 8.1 \\
\hline & BCK 9.91 & 7.87 & 302 & 68.0 & 136 & 8.7 & 8.1 \\
\hline & BCK 9.40 & 7.85 & 348 & 82.5 & 164 & B. 0 & 7.9 \\
\hline & BCK $7.8 \%$ & 8.13 & 448 & 134.0 & 204 & 8.1 & 7.9 \\
\hline \multirow[t]{7}{*}{6} & Control & 7.70 & 88 & 26.0 & 42 & 8.3 & 8.1 \\
\hline & BCK 12.36 & 7.66 & 1331 & 159.0 & 504 & 8.2 & 7.9 \\
\hline & BCK 11.83 & 7.82 & 1443 & 175.0 & 530 & 8.5 & 7.8 \\
\hline & BCK 11.09 & 8.07 & 935 & 155.0 & 414 & 8.8 & 8.0 \\
\hline & BCK 9.91 & 7.99 & 683 & 147.0 & 310 & 8.9 & 7.9 \\
\hline & BCK 9.40 & 7.79 & 568 & 144.0 & 246 & 8.9 & 7.9 \\
\hline & BCK 7.87 & 8.07 & 509 & 1.41 .0 & 232 & 8.9 & 7.8 \\
\hline \multirow[t]{7}{*}{7} & Control & 7.93 & 88 & 31.0 & 40 & 8.4 & 8.1 \\
\hline & BCK 12.36 & 7.64 & 1764 & 254.0 & 420 & 8.3 & 7.9 \\
\hline & BCK 11.83 & 7.82 & 1634 & 198.0 & 390 & 8.4 & 7.9 \\
\hline & BCK 11.09 & 8.06 & 1001 & 168.0 & 233 & 8.6 & 7.8 \\
\hline & BCK 9.91 & 8.03 & 759 & 167.0 & 140 & 8.7 & 7.8 \\
\hline & BCK 9.40 & 7.99 & 661 & 163.0 & 151 & 8.7 & 7.6 \\
\hline & BCK 7.87 & 8.11 & 537 & 158.0 & 130 & 8.9 & 7.4 \\
\hline
\end{tabular}

${ }^{\text {ac Cond. }}$ conductivity expressed as $\mu \mathrm{S} / \mathrm{cm}$, corrected to $25^{\circ} \mathrm{C}$.

$\mathrm{b}_{\mathrm{Alk}}$. = alkalinity expressed as $\mathrm{mg} / \mathrm{L} \mathrm{CaCO}_{3}$.

${ }^{C}$ Hardness expressed as $\mathrm{mg} / \mathrm{L} \mathrm{CaCO}_{3}$. test

$\mathrm{d}_{\text {Oxygen }}=\mathrm{mg}_{8} / \mathrm{L}$ dissolved oxygen of pooled replicates at beginning (new) and end (old) of 
Table 3-11. Sumary of chemical analyses of watex Erom Bear Creek sites during April 27-May 4, 1989

\begin{tabular}{|c|c|c|c|c|c|c|c|}
\hline \multirow[b]{2}{*}{ Analyses } & \multirow[b]{2}{*}{ Control } & \multirow[b]{2}{*}{$\mathrm{BCX} 12.36$} & \multicolumn{2}{|r|}{ Site } & \multirow[b]{2}{*}{ BCK 9.91} & \multirow[b]{2}{*}{ BCK 9.40} & \multirow[b]{2}{*}{ BCK 7.87} \\
\hline & & & BCK 11.83 & BCK 11.09 & & & \\
\hline \multicolumn{8}{|l|}{ pH } \\
\hline mean & 7.70 & 7.66 & 7.82 & 8.04 & 7.99 & 7.89 & 8. 13 \\
\hline SD & 0.21 & 0.07 & 0.05 & 0.05 & 0.06 & 0.15 & 0.03 \\
\hline range & $7.37-7.99$ & $7.59-7.80$ & $7.76-7.89$ & $7.94-8.09$ & $7.87-8.03$ & $7.61-8.03$ & $8.07-8.18$ \\
\hline \multicolumn{8}{|c|}{ Conductivity } \\
\hline mean & 85.9 & 1846.9 & 1612.6 & 952.8 & 667.1 & 569.6 & 500.9 \\
\hline SD & 1.5 & 546.2 & 414.7 & 51.2 & 162.8 & 105.1 & 26.8 \\
\hline range & $85-88$ & $1184-2460$ & $771-1980$ & $886-1026$ & $302-759$ & $348-661$ & $4,48-537$ \\
\hline \multicolumn{8}{|c|}{ Alkalintty } \\
\hline mean & 29.9 & 207.3 & 172.1 & 151.8 & 154.6 & 146.4 & 148.3 \\
\hline SD & 2.9 & 59.2 & 35.4 & 12.7 & 39.9 & 28.9 & 8.2 \\
\hline range & $26.0-33.0$ & $94.0-254.0$ & $94.0-198.0$ & $126.0-168.0$ & $68.0-180.0$ & $82.5-163.0$ & $134.0-158.0$ \\
\hline \multicolumn{8}{|l|}{ Hardness ${ }^{b}$} \\
\hline mean & 43.1 & 842.0 & 716.9 & $3 \varepsilon 9.0$ & 281.7 & 231.0 & 221.1 \\
\hline SD & 2.8 & 341.9 & 280.4 & 74.2 & 99.2 & 53.6 & 43.5 \\
\hline range & $40-48$ & $420-1220$ & $358-1020$ & $233-442$ & $136-356$ & $151-286$ & $130-260$ \\
\hline \multicolumn{8}{|c|}{ New Oxygen ${ }^{c}$} \\
\hline mean & 8.4 & 8.2 & 8.3 & 8.4 & 8.5 & 8,4 & 8.5 \\
\hline SD & 0.1 & 0.2 & 0.1 & 0.3 & 0.3 & 0.3 & 0.3 \\
\hline range & $8.3-8.4$ & $7.8-8.4$ & $8.2-8.5$ & $8.0-8.8$ & $8.3-8.9$ & $8.0-8.9$ & $8.1-8.9$ \\
\hline \multicolumn{8}{|c|}{ OLd Oxygen ${ }^{c}$} \\
\hline mean & 8.0 & 7.8 & 7.8 & 7.8 & 7.8 & 7.7 & 7.6 \\
\hline SD & 0.2 & 0.2 & 0.1 & 0.2 & 0.2 & 0.2 & 0.2 \\
\hline range & $7.6-3.1$ & $7.5-8.1$ & $7.6-8.0$ & $7.5-8.1$ & $7.6-8.1$ & $7.5-7.9$ & $7.4-7.9$ \\
\hline
\end{tabular}

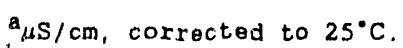

$b_{\mathrm{mg} / \mathrm{L}}$ as $\mathrm{CaC03}$.

$c_{\text {mg/L }}$ dissolved oxygen of pooled replicates at beginning (new) and end (old) of test. 
Snails released in Bear Creek efther remained at the site of release or moved townstream, whereas snalls released in several noncontaminated reference strearns, including Ish Creek, upper White Oak Creek, and upper First Creek, consistently moved upstream. At $B C K$ 12.36, the maxlmum downstream displacement was $16 \mathrm{~m}$ in $24 \mathrm{~h}$ (Fig. 3-1). Snails released in less-contaminated areas of Bear Creek moved little, and snails released in noncontaminated reference streams had a net upstream movement (maxinum distance -4 in in $24 \mathrm{~h}$ ). The causes and significance of differences in movement patterns among sites in Bear Creek and other streams is not yet known.

Chemical analyses showed that snails caged at BCK 12.36 accumulated cadniun, cobalt, aluminum, and strontium, whish suggests that these metals are present at $B C K 12.36$ in a blologlcally avallaile form. Other metals, such as manganese, magnesium, lithium, barium, and nlckel, were not acsumulated; sodfum was lost. The accumulation of cadmium and cobalt by the caged snails was correlated with the duration of exposure $(r=0.95, p=0.004$ for cadmiurn, and $r=0.83, p=0.040$ for cobalt). The duration of exposure was, in turn, correlated with snail mortality $(x=0.83, p=0.040)$. The mean accumulation of cadmium by snails at BCK 12.36, based on six experiments, was $9.0 \mathrm{\mu g} / g$ dxy wt; the mean for snails caged in the nonc ataminated reference stream was $<2.2 \mu \mathrm{g} / \mathrm{g}$ dry wt. Additionally, although filamentous algae collected from BCK 12.36 were enriched with cadmium (21. $\pm 2.6 \mu \mathrm{g} / \mathrm{g}$ dry wt compared with $<0.8 \mu \mathrm{g} / \mathrm{g}$ dry wt in filamentous algae from a noncontaminated stream), feeding experiments conducted in the laboratory suggested that snails did not accumulate much cadmium by ingesting contaminated food.

Overall, the results of the in sttu snall studies showed trends that were similar to those noted in other water quality assessments (including biological surveys and chemical analyses). Differences in responses of the organisms with distance downstream suggested that the upper reaches of Bear Creek remain biologically uninhabitable for most species. Long-term survival of Elimia in upper Bear Creek is presently unlikely because (1) snail mortality is directly correlated with duration of exposure in situ; (2) cadmium and nickel concentrations in upper Bear Creek are at least intermittently high $(0.04$ and 
BEAR CREEK $12 \mathrm{~km}$ SITE

\begin{tabular}{|c|c|c|}
\hline $\begin{array}{c}17 \text { DECEMBEA } 86 \\
(24 \mathrm{~h})\end{array}$ & $\begin{array}{c}12 \text { JANUARY BY } \\
(24 \mathrm{~h})\end{array}$ & $\begin{array}{c}3 \text { FEBRUAAY } 87 \\
(48 \mathrm{~h})\end{array}$ \\
\hline $\begin{array}{l}\because \cdots \\
:\end{array}$ & $\underbrace{}_{4.0 \mathrm{~m}}$ & $\begin{array}{l}4.0 \mathrm{~m} \\
50 \% \text { WERE STRESSED } \\
13 \% \text { WERE DEAD, } \\
50 \% \text { W S }\end{array}$ \\
\hline
\end{tabular}

Fig. 3-1. Posftions of snalls 24 or $48 \mathrm{~h}$ after release at $B C K$ 12.36. Rectangles show the point where the sna11s were released; solid dots indicate the positions of snalis that were recovered after the findicated time. The solid rectangle (middle panel) indicates that all snails except one were recovered at the release site. In each panel, the direction of water flow was from top to bottom. 
$0.18 \mathrm{mg} / \mathrm{L}$, respectively; ; and (3) snails transplanted to BCK 12.36 move downstream.

\subsection{DISCUSSION}

Groundwater contaminci-ad by materials that leach from the S-3 ponds enters Bear Creek upstream from BCK 12.36 (Fig. 1-1). Water fro.a BCK 12.36 was, on average, about 16 times higher in conductivily $(4,043 \pm 1,457 \mu \mathrm{S} / \mathrm{cm}, \mathrm{n}=5$ test periods $)$ than water from oth $\sim$ r local hearwater streams (mean $=243 \mu \mathrm{S} / \mathrm{cm}$ for six small streams near ORNL; J. M. Loar, ORNL/ESD, 1988, personal communication to A. J. Stewart, ORNL/ESD, able 2-8). Water from BCK 12.36 was also toxic to fathead minnow larvae on five of the first seven testing dates (Table 3-2), and to Ceriodaphnia in the tests conducted during March 10-17, 1988, and April 27-May 4, 1989. Results of both the chemical analyses and toxicity tests are consistent in demonstrating the degraded quality of water in the upper reaches of Bear Creek.

Sites BCK 7.87 and BCK 5.15 were both tested with fathead minnow larvae on five dates (July 11 and October 10, 1984; April 10 and October 22, 1985; and April 10 1986), and BCK 3.25 was tested on four of these dates (Table 3-1). Water from BCK 7.87 significantly lowered fish survival in two of five tests; water from $B C K 5.15$ significantly lowered fish survival in two of five tests; and water from BCK 3.25 was apparently toxic to the fish in one of four tests (Table 3-2). The 14 site-date combinations 1 isted above include five tests that indicated significant levels of toxicity. These five tests accounted for 428 $(5 / 12)$ of all tests indicating the presence of toxicity on those five dates. However, inost of these site-date combinations had unacceptably high levels of within-test variability, with survival ranging from 0 to 1008 among replicates (Table 3-12). Therefore, although statistically significant reductions (based on Dunnet.t's test) in mean survival of fathead minnow larvae were noted in tests using water collected from BCK 3.25 on April 10, 1985, and from BCK 5.15 on October 22, 1985, (Table 3-2), the watex collected for these site-date combinations should not be considered to have been toxic to the fish. The temporal progression of mortality in the tests having high within-test variability yielded few clues about possible causal agent(s). Using 
Table 3-12. Within-test survival ( 8 ) of fathead minnow larvae in toxicity tests of water from three sites on Bear Creek (BCK) and four sites on tributaries of Bear Creek (NT). $R=$ replicate

\begin{tabular}{|c|c|c|c|c|c|c|}
\hline \multirow[b]{2}{*}{ Site } & \multicolumn{5}{|c|}{ Initial date of test } & \multirow[b]{2}{*}{$10 / 22 / 85$} \\
\hline & $\mathrm{R}$ & $7 / 11 / 84$ & $10 / 10 / 84$ & $4 / 10 / 85$ & $6 / 26 / 85$ & \\
\hline \multirow[t]{4}{*}{ Control } & 1 & 100 & 100 & 100 & 100 & 100 \\
\hline & 2 & 100 & 67 & 100 & 50 & 100 \\
\hline & 3 & 100 & 100 & 100 & 89 & 100 \\
\hline & 4 & 90 & 100 & 100 & 70 & 100 \\
\hline \multirow[t]{4}{*}{ BCK 7.87} & 1 & 60 & 89 & 100 & $\cdots$ & 40 \\
\hline & 2 & 70 & 90 & 100 & $\ldots$ & 80 \\
\hline & 3 & 73 & 90 & 100 & $\ldots$ & 33 \\
\hline & 4 & 44 & 78 & 90 & $\cdots$ & 70 \\
\hline \multirow[t]{4}{*}{ BCK 5.15} & 1 & 60 & 100 & $90^{\circ}$ & $\cdots$ & $50^{a}$ \\
\hline & 2 & 25 & 100 & 100 & $\cdots$ & 0 \\
\hline & 3 & 33 & 90 & 100 & $\cdots$ & 30 \\
\hline & 4 & 80 & 100 & 20 & $\cdots$ & 100 \\
\hline \multirow[t]{4}{*}{ BCK 3.25} & 1 & $\cdots$ & 89 & $100^{a}$ & $\cdots$ & $100^{\circ}$ \\
\hline & 2 & $\ldots$ & 90 & 0 & $\ldots$ & 0 \\
\hline & 3 & $\cdots$ & 70 & 50 & $\ldots$ & 100 \\
\hline & 4 & $\cdots$ & 89 & 0 & $\cdots$ & 100 \\
\hline \multirow[t]{4}{*}{ NT4 } & 1 & $\cdots$ & 100 & $0^{a}$ & 70 & $\cdots$ \\
\hline & 2 & -.. & 100 & 20 & 80 & $\cdots$ \\
\hline & 3 & $\cdots$ & 100 & 100 & 50 & $\cdots$ \\
\hline & 4 & $\cdots$ & 89 & 100 & 70 & $\cdots$ \\
\hline \multirow[t]{4}{*}{ NT7 } & 1 & $\cdots$ & 67 & $100^{\mathrm{a}}$ & 10 & $\cdots$ \\
\hline & 2 & $\cdots$ & 100 & 100 & 0 & $\cdots$ \\
\hline & 3 & $\cdots$ & 50 & 100 & 0 & $\cdots$ \\
\hline & 4 & $\cdots$ & 80 & 100 & 0 & $\cdots$ \\
\hline \multirow[t]{4}{*}{ NT8 } & 1 & $\cdots-$ & 90 & $100^{a}$ & 60 & $\cdots$ \\
\hline & 2 & $\ldots$ & 100 & 90 & 60 & $\ldots$ \\
\hline & 3 & $\cdots$ & 100 & 20 & 50 & $\ldots$ \\
\hline & 4 & $\cdots$ & 80 & 90 & 90 & $\cdots$ \\
\hline \multirow[t]{4}{*}{ NT14 } & 1 & $\cdots$ & .. & $10^{a}$ & $\ldots$ & $\cdots$ \\
\hline & 2 & $\cdots$ & $\cdots$ & 100 & $\cdots$ & $\cdots$ \\
\hline & 3 & $\cdots$ & $\cdots$ & 100 & $\cdots$ & $\cdots$ \\
\hline & 4 & $\cdots$ & $\cdots$ & 10 & $\cdots$ & $\cdots$ \\
\hline
\end{tabular}

aThe variability in survival among the four replicates included in this test was unusually high. 
BCK 3.25 (October 22,1985 ) as an example, replicates 1,3 , and 4 had 1008 survival over the 7 -d test, while replicate 2 had three deaths on the day 4 of the test, three deaths on day 5 , two deaths on day 6 , and two deaths on day 7. Pathogens may have been involved: if one fathead minnow larva in a test replicate dies because of a pathogenic fungus, for example, other larvae in that test chamber may have a greater risk of death from the same agent. The level of within-test variability indicated in Table 3-2 (footnote c) and Table 3-12 was uncommon, and its cause remains unclear.

Water from all Bear Creek sites downstream from BCK 12.36 was toxic to fathead minnow larvae much less frequently than was water from BCK $12.36(6 / 8=758$ of the tests at BCK 12.36 showed toxicity vs $11 / 48$ $=238$ of the tests at sites below BCK 12.36, excluding the four tests with high within-test variability; see Table $3-2$ ). The relatively rapid reduction in toxicity downstream from BCK 12.36 may be because of (1) dilution of contaminants by inputs of noncontaminated spring water; (2) imnobilization, deactivation, or chemical conversion of substances toxic to fathead minnow larvae; or (3) some combination of these processes. Because conductivity declined more or less logarithmically with distance downstream, and because conductivity tends to be a conservative property of water (Wetzel 1983; Stewart 1988), reduction of toxicity due to dilution is probably the more important process.

Water from the upstream Grassy Creek site (GCK 2.4) significantly lowered survival of the minnow larvae in two of the four tests, and water from the downstream Grassy Creek site (GCK 1.4) significantly reduced survival of the larvae in three of the four tests. In all four tests, the minnows reared in water from the downstream site had lower survival than those reared in water from the upstream site (Table 3-5). Both the $t$ statistic calculated in comparing survival of the $f i s h$ in water from the two Grassy Creek sites $(p \approx 0.058, \mathrm{df}=3$ ) and the probability that differences between the upstream and downstream sites were because of chance alone $\left(0.5^{4}=0.0625\right)$ were close to statistical significance. Both calculations suggest that water quality changes detrimental to the survival of fathead minnow larvae occurred in Grassy 
Creek somewhere between GCK 2.4 and GCK 1.4; such changes, however, were not conspicuously related to either pH or to conductivity (Table 3-13). Tributaries NT4, NT7, and NT8, which intercept Bear Creek near $B C K$ 11.1, $B C K$ 9.9, and $B C K$ 9.3, respectively, were tested for toxicity to fathead minnow larvae on two, three, and four dates, respectively. NT14, which empties into Bear Creek near Gum Hollow Road, was tested for toxicity only once (April 10, 1985). Three of the 10 tests on' these tributaries had high levels of within-test variability (Table 3-8), and al1 3 tests were initiated on April 10, 1985, the same date that highvariability among replicates was observed in the tests for BCK 5.15 and BCK 3.25 (Table 3-8). Because 3 of the 10 tests of water from Bear Creek tributaries were suspect, only a few definitive statements about the toxicity of water from NT4, NT7, and NT8 are possible: (1) water from NT4 was clearly not toxic on October 10, 1984 (survival in the four replicates was $100,100,100$ and 908); (2) water from NT7 on that date may or may not have been toxic (survival in 4 replicates was 50, 67, 80, and 1008); and (3) water from NT7 on April 10, 1985, was definitely not toxic (survival in all 4 replicates was 1008). Additional tests would be required before more definitive conclusions could be reached about the toxicity of these Bear Creek tributaries.

The Ceriodaphnia tests that were conducted in 1988 and 1989 were in excellent agreement with respect to longitudinal patterns in water quality in Bear Creek. In each test, toxicity was evident near the headwaters of the stream (i.e, BCK 12.36), but was not detected about $4.5 \mathrm{~km}$ farther downstream. However, the test in 1989 showed that biological quality in the stream was lower than it was in 1988. The increase in toxicity in 1989, relative to that detected in 1988 , is attributed to differences in weather during the two test periods. Intense rainfall occurred the night before the start of the test in 1988, and water in Bear Creek was unusually turbid for several days thereafter. Inputs of rainwater and runoff from areas adjacent to the stream conspicuously affected the chemical conditions in the stream. At BCK 12.36, for example, the 7-d average conductivity during the 1988 toxicity test was only about 668 as high as it was during the 1989 test $(1226 \pm 413 \mu \mathrm{S} / \mathrm{cm}$ vs $1847 \pm 546 \mu \mathrm{S} / \mathrm{cm}$, respectively). 
Table 3-13. Mean conductivity $(\mu \mathrm{s} / \mathrm{cm})$ and $\mathrm{pH}$ of control water (= dechlorinated tap water) and of water collected from two sites on Grassy Creek (GCK)

\begin{tabular}{|c|c|c|c|c|c|c|c|c|}
\hline \multirow[b]{3}{*}{ Site } & \multicolumn{6}{|c|}{ Initial date of } & \multirow{2}{*}{\multicolumn{2}{|c|}{$10 / 22 / 85$}} \\
\hline & \multicolumn{2}{|c|}{$6 / 6 / 84$} & \multicolumn{2}{|c|}{$7 / 11 / 84$} & \multicolumn{2}{|c|}{$10 / 10 / 84$} & & \\
\hline & $\mathrm{pH}$ & Cond. & $\mathrm{pH}$ & Cond. & $\mathrm{pH}$ & Cond. & $\mathrm{pH}$ & Cond. \\
\hline Control & 7.86 & $\ldots$ & 7.85 & 245 & 7.32 & 242 & 7.62 & 258 \\
\hline GCK 2.4 & 8.30 & $\ldots$ & 8.24 & 212 & 7.83 & 246 & 6.78 & 249 \\
\hline GCK 1.4 & 8.18 & $\ldots$ & 8.17 & 225 & 8.05 & 282 & 7.79 & 2.64 \\
\hline
\end{tabular}


The results of the two Ceriodaphnia tests are also in good agreement with the results of effluent tests with this species in the context of salinity limits. For example, the Bear Creek tests showed that a conductivity threshold of about $600 \mu \mathrm{S} / \mathrm{cm} \mathrm{might}$ be useful in predicting the probability of "passing" or "failing" either the survival or fecundity endpoints of a Ceriodaphnia test (Table 3-14). Using data from the 1988 and 1989 Ceriodaphnia tests combined, the ratio of passing to failing ( $P: F$, based on significant reductions either in survival or fecundity, relative to controls) for all Bear Creek samples in which conductivity was less than $600 \mu \mathrm{S} / \mathrm{cm}$ was $20: 6$; the $\mathrm{P}: \mathrm{F}$ for samples in which conductivity exceeded $600 \mu \mathrm{S} / \mathrm{cm}$ was 3:7 (Table 3-13).

Additionally, four of the six failures that occurred in low-conductivity samples involved water from BCK 12.36. Thus, (1) the probability of an ambient water showing evidence of toxicity to Ceriodaphnia is much greater if its conductivity exceeds about $600 \mu \mathrm{S}$ and (2) materials other than major determinants of conductivity must have contributed to the toxicity of the water from $\mathrm{BCK} 12.36$.

Finally, additional studies to determine the extent to which movement patterns of Elimia can be reliably used in situ as bioindicators of stream water quality seem warranted. Replicated experiments conducted during June 1988 showed that snail movement patterns in noncontaminated streams were statistically indistinguishable from one another (net movement was upstream at mean rates of 0.6 to $2.3 \mathrm{~cm} / \mathrm{h}$ ). The large differences in snail movement patterns observed between sites in Bear Creek suggest that such in situ tests can be used to detect adverse ecological conditions in streams. 
Table 3-14. Number of Ceriodaphnia test endpoints passed or falled in Bear Creek samples in relation to conductivity (less than or greater than $600 \mu \mathrm{S} / \mathrm{cm}$ ). The criterion for passing the survival endpoint of

a test was based on Fisher's Exact Test $(p<0.05)$, relative to controls; the criterion for passing the fecundity endpoint was based on analysis of varlance followed by Dunnett's rest

$(p<0.05)$. This analysis only includes data for the concentrations of water at and below the lowest concentration causing the simultaneous fallure of both endpoints

\begin{tabular}{|c|c|c|c|}
\hline \multirow[b]{2}{*}{ Toxicity test endpoint } & \multirow[b]{2}{*}{ Criterion } & \multicolumn{2}{|c|}{ Conductivity } \\
\hline & & $<600 \mu \mathrm{S} / \mathrm{cm}$ & $>600 \mu \mathrm{S} / \mathrm{cm}$ \\
\hline Survival & Passed & 10 & 1 \\
\hline Survival & Failed & $3^{a}$ & 4 \\
\hline Fecundity & Passed & 10 & 2 \\
\hline Fecundity & Failed & $3^{a}$ & 3 \\
\hline Total number passed & & 20 & 3 \\
\hline Total number failed & & 6 & 7 \\
\hline
\end{tabular}

ancludes two cases that involved tests with water from BCK 12.36. 


\section{FISHES}

\subsection{INTRODUCTION}

Fish population and community studies can be used to assess the ecological effects of changes in water quality and habitat. Such studies offer several advantages over other indicators of environmental quality (Karr et al. 1986; Karr 1987) and are especially relevant to an assessment of the biotic integrity of Bear Creek. Fish communities, for example, include several trophic levels, with species that are at or near the end of food chains. Consequently, they integrate the direct effects of water quality and habitat change on primary producers (periphyton) and consumers (benthic invertebrates) that are utilized for Eood. Because of these trophic interrelationships, the well-being of fish populations has often been used as an index of water quality (e.g., Weber 1973; Greeson et al. 1977; Karr et al. 1986). Moreover, statements about the condition of the fish community are better understood by the general public (Karr 1981).

The objectives of the fish community studies were (1) to characterize spatial and temporal patterns in the distribution and abundance of fishes in Bear Creek and (2) to document any effects on fish community structure and function resulting from implementation of remedial actions in Bear Creek Valley. The sampling sites were located on Bear Creek downstream of known disposal areas (Figs. 1-1 and 1-2). Site BCK 12.36 is impacted by the $S-3$ pond groundwater plume. Site BCK 11.83, which is located at the east end of the landfill/oil landfarm area, is also affected by the S-3 pond plume. Site BCK 11.09 is just downstream from the tributaries that drain the sanitary landfill/oil landfarm area. Sites BCK 9.91 and BCK 9.40 are immediately below tributaries that drain burial grounds north of Bear Creek. The remaining two sites, $B C K 7.87$ and $B C K 3.25$, receive contaminants that are transported via Bear Creek from the upstream disposal areas. 


\subsection{METHODS}

\subsubsection{Population Surveys}

Quantitative sampling of the fish populations at seven sites in Bear Creek and reference sites in Grassy Creek and Mill Branch was conducted periodically by electroshocking from May 1984 to December 1987 to estimate population size (densities in numbers and biomass per unit area). The mean langth of the sampling reaches ranged from 54 to $201 \mathrm{~m}$ at the Bear Creek sites and from 49 to $59 \mathrm{~m}$ at the reference sites (Table 2-12). Lengths of the sampling reaches were adjusted based on fish density following the initial surveys in 1984 and 1985. Fish sampling sites either overlapped or were within $100 \mathrm{~m}$ of the benthic invertebrate sampling sites.

Qualitative sampling of Bear Creek watershed was done during the initial phases of the 1984 survey, in May to July 1987, and in June 1988. Areas sampled included lower Bear Creek (BCK 0.0 to BCK 3.25), large pools in Bear Creek, and all tributaries and springs flowing into Bear Creek.

\subsubsection{Fleld Sampling Procedures}

All streain sampling was conducted using one or two Smith-Root Model 15A backpack electrofishers, depending on stream size. Each unit has a self-contained, gasoline-powered generator capable of delivering up to 100 volts of pulsed direct current. A pulse frequency of 90 to $120 \mathrm{~Hz}$ was used, and the output voltage was adjusted to the optimal value (generally 400 volts or less) based on the specific conductance of the water. The circular (ring) electrode $a$ : the end of the fiberglass anode pole was fitted with a nylon net $(0.64-\mathrm{cm}$ mesh) to allow the electrofisher operator to collect stunned fish.

After a $0.64-\mathrm{cm}$-mesh seine was stretched across the upper and lower boundaries of the reach to restrict fish movement, a two- to five-person sampling team electroshocked the site in an upstream direction on three consecutive passes. If fish numbers captured during the first pass were extremely low or zero, then only one pass was made. Depending upon the turbidity of the water, the consecutive passes could not always be made immediately. Rather, fish were processed after each pass to allow 
sufficient time for the water to clear before another pass was initiated. Stunned fish were collected and held in wire mesh cages (0.64-cm diameter) or in buckets with small holes during further sampling. Separate containers were used for each pass.

After electroshocking, fish were anesthetized with MS-222 (tricaine methanesulfonate), identified, measured to the nearest $0.1 \mathrm{~cm}$ (total length), and weighed to the nearest $0.1 \mathrm{~g}$ (for fish weighing less than $100 \mathrm{~g}$ ) or gram (for fish, weighing greater than $100 \mathrm{~g}$ ) using Pesola spring scales. At sites with high fish densities, individuals were recorded by $1-\mathrm{cm}-\mathrm{size}$ classes and species. After 25 individuals of a species-size class were measured and weighed, additional members of that size class were only measured. Length-weight regressions (SAS 1985b) based on data from the 25 individual fish were later used to estimate missing weights. Sex, reproductive state, disposition (i.e., dead or kept for laboratory identification and reference collection), and presence of any abnormalities (e.g., external parasites, skeletal deformities) were also recorded if known. After the fish from all passes were processed, they were allowed to fully recover from the anesthesia and returned to the stream. Any additional mortality occurring as a result of processing was recorded at that time.

Supplemental site information collected at the time of fish sampling included percent cloud cover, shocking time(s) for each pass, and the length, width, and depth of the sampling reach. Conductivity, $\mathrm{pH}$, water temperature, and dissolved oxygen were measured with a Horiba Mode1 U7 battery-powered field sampler, and turbidity was measured with a H.F. Instruments Mode1 DRT-15 portable turbidimeter. In the initial surveys, dissolved oxygen was measured with a YSI Model 51B meter and conductivity and water temperature were measured with a Cole Parmer Model R-1491-20 LCD meter. Turbidity was measured with the same equipment throughout the study period, but $\mathrm{pH}$ was not measured in the initial surveys. 


\subsubsection{Data Analys is}

After reviewing the information on the field data sheets for completeness and accuracy, the data were entered and stored on an IBM 3033 computer and analyzed using the SAS $(1985 a, b)$.

To select the most appropriate technique for estimating fish population size (N), both the removal method (e.g., Zippin 1956, 1958; Carle and Strub 1978) and the mark-recapture method (Petersen 1896) were evaluated in June 1984. The three-pass removal method was used at all sites except BCK 11.5 where densities were very low; at four sites, a combination of the two methods was used to test the assumptions of each method (Gatz and Loar 1988). Violations to the assumptions of both methods were noted at a number of sites. Because these comparisons did not identify one method as being better than the other (i.e., fewer. assumptions violated), other criteria were used to select the most appropriate technique for estimating fish population size. The removal method was selected to minimize both mortality and sampling time. Therefore, all sampling after the May-June 1984 sampling was performed using the three-pass removal method (Carle and strub 1978).

Biomass was estimated by multiplying the estimated population number by the mean weight per individual. To calculate density and biomass per unit area, total numbers and biomass were divided by the surface area $\left(\mathrm{m}^{2}\right)$ of the study reach. For each sampling date, surface area was estimated by multiplying the length of the reach by the mean width based on measurements taken at 5-m intervals.

Condition factors $(K)$ were used as a measure of the relative plumpness of the fish. They were calculated for individual fish by site and species using the formula:

$$
K=100 \text { (weight/length }{ }^{3} \text { ), }
$$

with weight in grams and total length in centimeters (Hile 1936). Fish without measured weights were not used in calculations of condition factors. Comparisons of condition factors between sites and between sampling periods were made using an ANOVA procedure (PROC GLM) on untransformed data (SAS 1985b) because the condition factors exhibited 
homogeneity of variance as estimated with the UNIVARIATE procedure (SAS 1985a). If the GLM procedure indicated significant differences in condition factors between groups, the Tukey test was performed to identify those groups that were significantly different. The May-June 1984 sample was omitted from the comparison between sampling periods because the field procedures differed from those employed in all later samples.

\subsection{RESULTS}

\subsubsection{Species Richness and Composition}

A total of 14 species was collected in the 8 quantitative surveys of Bear Creek conducted between 1984 and 1987 (Table 4-1). The lowermost site on Bear Creek, BCK 3.25, had the highest species richness; all 14 species were found there at one time or another. A weir at BCK 4.55 limits access of fish to upper Bear Creek, as indicated by the collection of only seven species above the weir. Only four species were found at the uppermost sites ( $B C^{\prime} .1 .1 .09$ to 12.36), while six to seven species were collected at the zchir sites above BCK 4.55 . The species richness in Bear Creek (3-15 species) compared favorably to that found in the reference streams (6-9 species), which had more centrarchid (sunfish) and fewer cyprinid (minnows) species than Bear Creek.

Qualitative surveys of Bear Creek conducted by ORNL/ESD staff added an additional four species to those found in the quantitative sampling. A single green sunfish (Lepomis cyanellus) was collected at BCK 5.15 in May 1984 and approximately 15 redbreast sunfish (Lepomis auritus) were collected from a large pool at BCK 6.89 in June 1988. Surveys in 1987 found three more species in lower Bear Creek below BCK 3.25, including bluegill, redbreast sunfish, and the bluntnose minnow (Pimephales notatus). The absence of these species, especially the latter two, from regular surveys of $B C K 3.25$ is puzzling.

In general, species richness increased as a function of stream size but was highly influenced by two physical factors. First, the barrier to fish movement at the weir provided a sharp break in richness between the lowest site and sites upstream of the weir. Second, groundwater 


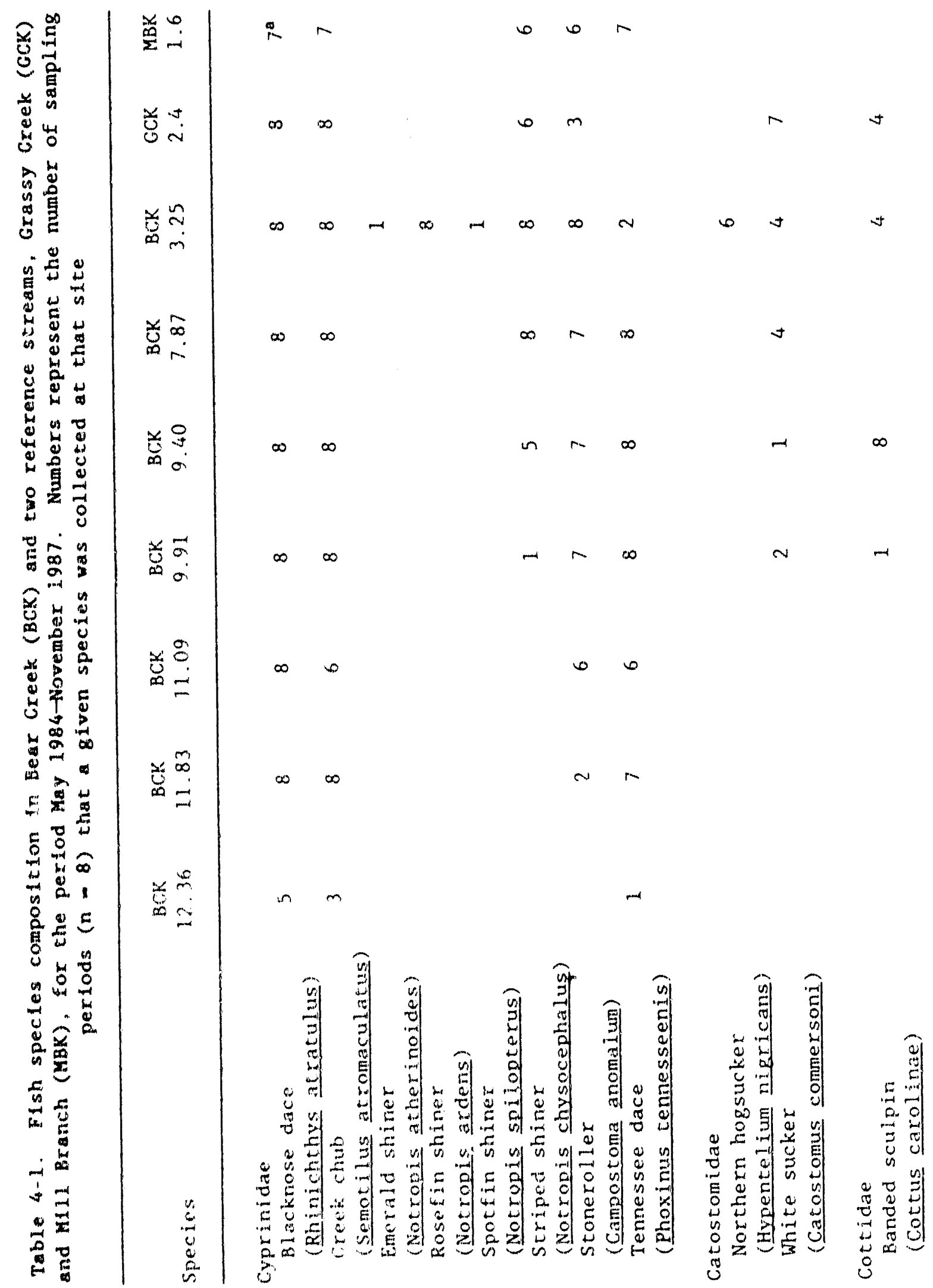




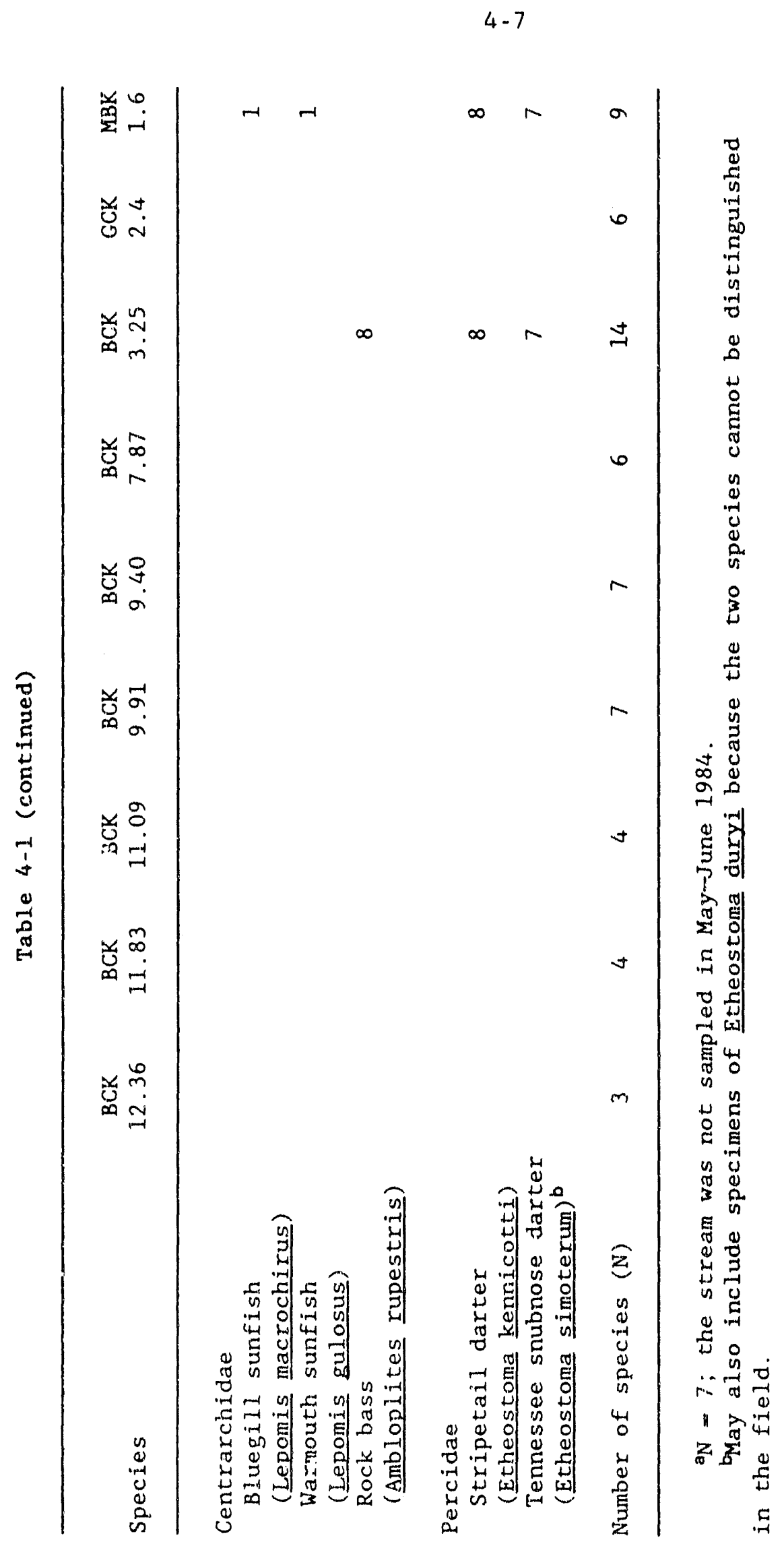


entering Bear Creek from SS's at BCK 9.41 provided permanent flow and moderation of the thermal regime (Sect. 2.2.2). At BCK 9.40, temperatures were noticeably cooler in the summer (Fig. 2.6) as a result of SS5, and a population of the banded sculpin (Cottus carolinae) was only found at this site (and below the weir at BCK 3.25). A preference for cooler temperatures has been noted for sculpins (Becker 1983; Pflieger 1975) and is also suggested by data for other area streams (Loar 1987, J. M. Loar, ORNL/ESD, 1988, persoral communication to M. G. Ryon, ORNL/ESD). The added flow provided by the spring changed the flow regime from intermittent to permanent at most sites below BCK 9.41 (Table 2-8), and the increased size of Bear Creek probably resulted in the presence of the white sucker (Catostomus commersoni) and the striped shiner.

Trophic analysis of the fish community in Bear Creek indicated that the upper sites were dominated by omnivores and insectivores, but the number of insectivorous species increased with increased stream size (Table 4-2). Only one herbivore, the stoneroller (Campostoma anomalum), inhabits Bear Creek. Piscivores were also represented by a single species, rock bass, which was only found at $\mathrm{BCK} 3.25$. Fish that are intolerant of habitat degradation and poor water quality, as defined by Karr et al. (1986), were limited above the weir (at BCK 4.55) to one species, the banded sculpin. Below the weir, seven intolerant species were found. Karr et al. (1986) determined intolerance based on studies of midwestern streams, and the extrapolation of their conclusions to East Tennessee is suspect because of differences in the importance of the disrupting factors (e.g., intolerance to silt may be more important in streams of the Midwest than in streams of the Southeast).

The species found in upper Bear Creek may represent a fauna adapted to headwater conditions and tolerant of abrupt changes in environmental conditions. Matthews and Styron (1981) tested the mountain redbelly dace, a close relative of the Tennessee dace, and several other species from intermittent headwater streams for their response to rapid changes in $\mathrm{pH}$, dissolved oxygen, and temperature. They found significant difterences between headwater and mainstream species in their ability to survive abrupt environmental changes. If a similar tolerance difference exists between the species in the uppermost reaches (sites BCK 12.36 to 
Table 4-2. Trophic structure and intolerance of fish communities

in Bear Creek (BCK), Grassy Creek (GCK), and M1ll Branch (MBK) based on sampling conducted from May 1984 through November 1987. Number of fish in each category is shown

\section{Trophic classification}

\begin{tabular}{lccccc} 
Site & $\begin{array}{c}\text { Herbi- } \\
\text { vore }\end{array}$ & $\begin{array}{c}\text { Omni- } \\
\text { vore }\end{array}$ & $\begin{array}{c}\text { Insect } \\
\text { vore }\end{array}$ & $\begin{array}{c}\text { Pisci- } \\
\text { vore }\end{array}$ & $\begin{array}{c}\text { Intol - } \\
\text { erant }^{\mathrm{b}}\end{array}$ \\
\hline BCK 12.36 & 0 & 2 & 1 & 0 & 0 \\
BCK 11.83 & 1 & 2 & 1 & 0 & 0 \\
BCK 11.09 & 1 & 2 & 1 & 0 & 0 \\
BCK 9.91 & 1 & 2 & 4 & 0 & 1 \\
BCK 9.40 & 1 & 2 & 4 & 0 & 1 \\
BCK 7.87 & 1 & 2 & 3 & 0 & 0 \\
BCK 3.25 & 1 & 2 & 11 & 1 & 7 \\
GCK 2.4 & 1 & 1 & 4 & 0 & 1 \\
MBK 1.6 & 1 & 2 & 5 & 1 & 2 \\
\hline
\end{tabular}

a Based on information in Pflieger (1975), Smith (1979), Becker (1983), Cooper (1983), and D. A. Etnier, University of Tennessee, 1987, unpublished data; classification represents major food component and, for omnivores, includes active ingestion of plant material.

${ }^{b}$ Number of species that are intolerant of ecological disturbances (e.g., poor water quality or habitat degradation), as defined by Karx et al. (1986). 
BCK 11.09) and those found only at lower sites, then perhaps the waterquality stresses (Sect. 2.2.) occurring in upper Bear Creek (Sect. 2.1.1) are responsible for the low species richness in that reach of the stream.

Historical collections of Bear Creek in 1941 indicate a more diverse fauna (D. A. Etnier, University of Tennessee, 1978, personal communication to M. G. Ryon, ORNL/ESD) than is present now. Included in these surveys were large numbers of the flame chub (Hemitrema flammea), normally an uncommon inhabitant of spring-fed streams. This finding suggests that degraded water quality or reduced habitat availability significantly altered the original faunal composition of Bear Creek. Comparisons with other stream fish communities in the Oak Ridge area also indicated that the fish assemblage in Bear Creek was limited. Although the fauna above the weir at BCK 4.55 was comparable to that of reference streams, species were absent that should have been present (e.g., Etheostoma spp.). The fish fauna of East Fork Poplar Creek (EFPC) was more diverse, consisting of 41 species, including species of the genera Micropterus, Moxostoma, and Ictalurus (Ryon and Loar 1988). At least some of these species were expected at the site below the weir (BCK 3.25). Surveys by other agencies have reported at least five species from lower Bear Creek that also inhabit EFPC but have not been collected at BCK 3.25 (Table 1-3). Finally, sore of the species found at BCK 3.25 (e.g., Etheostoma spp.) should have occurred at sites further upstream. The influence of the weir is obvious, and this barrier probably impedes the recovery of upper Bear Creek in nuch the same manner as the weirs on White Oak Creek (J. M. Loar, ORNL/ESD, 1987, personal communication to M. G. Ryon, ORNL/ESD).

\subsubsection{Density and Biomass}

Population surveys of Bear Creek were conducted during eight sampling periods from 1984 to 1987 to estimate species biomass and density. The total biomass and densities at each site for each sampling period are given in Table 4-3. Similar data for individual species are given in Appendix B, Tables B-1 to B-16. In general, fish densities and biomass did not demonstrate any persistent pattern with distance downstream over the three years of sampling. 
Tablo 4-3. Total fish density (Individuals $/ \mathrm{m}^{2}$ ), total biconss $\left(8 / \mathrm{m}^{2}\right)$, and species richness for May 1984 through Novembex 1987 in Bear Creek (BCX) and two reference streams, Grassy Croek (GCX) and Mi11 Branch (MBK). ns = Mot sampled

\begin{tabular}{|c|c|c|c|c|c|c|c|c|c|}
\hline Sarnpling periods & $\begin{array}{c}\text { BCK } \\
12.36\end{array}$ & $\begin{array}{c}\text { BCK } \\
11.83\end{array}$ & $\begin{array}{c}\text { BCK } \\
11.09\end{array}$ & $\begin{array}{c}\text { BCK } \\
9.91\end{array}$ & $\begin{array}{c}\text { BCK } \\
8.40\end{array}$ & $\begin{array}{c}\text { BCK } \\
7.87\end{array}$ & $\begin{array}{c}B C K \\
3.25\end{array}$ & $\begin{array}{l}\text { GCK } \\
2.4\end{array}$ & $\begin{array}{c}\text { MBK } \\
1.6\end{array}$ \\
\hline \multicolumn{10}{|l|}{ May-June $1984^{a}$} \\
\hline Density & 0 & 0.08 & 0.73 & 0.86 & 0.85 & 1.11 & 1.72 & 1.24 & NS \\
\hline Biomass & 0 & 0.40 & 0.81 & 2.44 & 2.77 & 3.08 & 7.48 & 2.45 & NS \\
\hline Richness & 0 & 2 & 1 & 3 & 5 & 5 & 9 & 5 & NS \\
\hline \multicolumn{10}{|l|}{ March-April $1985^{a}$} \\
\hline Density & 0.10 & 3.85 & 2.50 & 1.88 & 1.07 & 4.01 & 1.67 & 1.59 & 2.64 \\
\hline Biomass & 0.43 & 5.97 & 5.42 & 5.87 & 3.86 & 7.89 & 8.51 & 2.88 & 4.91 \\
\hline Richness & 2 & 3 & 4 & 6 & 6 & 5 & 11 & 6 & 7 \\
\hline \multicolumn{10}{|l|}{ July-August 1985} \\
\hline Density & 0.03 & 2.01 & 0.03 & 2.16 & 4.24 & 3.41 & 2.06 & 1.51 & 1.97 \\
\hline Biomass & 0.02 & 3.76 & 0.02 & 2.28 & 6.65 & 8.56 & 7.19 & 3.90 & 4.26 \\
\hline Richness & 1 & 3 & 1 & 4 & 6 & 5 & 9 & 6 & 8 \\
\hline \multicolumn{10}{|c|}{ November-December 1985} \\
\hline Density & 0.01 & 3.92 & 0.88 & 0.93 & 1.81 & 4.47 & 1.35 & 0.82 & 1.52 \\
\hline Biomass & 0.01 & 9.83 & 4.03 & 2.41 & 3.58 & 6.95 & 3.63 & 2.03 & 2.70 \\
\hline Richness & 1 & 3 & 4 & 4 & 6 & 6 & 11 & 4 & y \\
\hline \multicolumn{10}{|l|}{ March-April 1986} \\
\hline Density & 0.29 & 1.36 & 0.96 & 1.38 & 1.58 & 3.52 & 1.48 & 0.86 & 1.33 \\
\hline Biomass & 1.04 & 2.35 & 1.82 & 3.14 & 4.47 & 6.59 & 6.82 & 1.92 & 2.28 \\
\hline Richness & 2 & 3 & 4 & 4 & 6 & 6 & 10 & 4 & 5 \\
\hline \multicolumn{10}{|c|}{ November-January $1986 / 87$} \\
\hline Density & 0 & 3.43 & 1.54 & 1.58 & 3.92 & 5.70 & 0.91 & 1.12 & 2.21 \\
\hline Biomass & 0 & 8.40 & 4.21 & 2.20 & 5.66 & 6.30 & 2.12 & 2.16 & 2.11 \\
\hline Richness & 0 & 4 & 4 & 5 & 5 & 6 & 10 & 4 & 6 \\
\hline \multicolumn{10}{|l|}{ March-Apr11 1987} \\
\hline Density & 0.17 & 1.80 & 0.93 & 2.62 & 1.66 & 4.33 & 1.11 & 0.76 & 1.66 \\
\hline Biomass & 0.90 & 6.21 & 2.75 & 8.80 & 3.48 & 6.55 & 2.72 & 2.07 & 1.60 \\
\hline Richness & 3 & 4 & 4 & 5 & 6 & 6 & 11 & 4 & 7 \\
\hline \multicolumn{10}{|c|}{ October-November 1987} \\
\hline Density & 0 & 1.83 & 1.26 & 2.03 & 5.97 & 3.46 & 1.44 & 1.16 & 2.30 \\
\hline Blomass & 0 & 2.61 & 0.74 & 4.29 & 9.09 & 5.04 & 2.84 & 2.96 & 2.56 \\
\hline Richness & 0 & 3 & 4 & 4 & 5 & 5 & 10 & 3 & 8 \\
\hline
\end{tabular}

ADate on two sites, BCK 10.32 and BCK 4.55, sampled in 1984 and early 1985 are not included in this report. They were dropped from the sampling program because no significant ecological difference was found between the sites and adajecent sites. Data on the t.wo sites are prosented in Loar et al. (1985). 
In the first sampling period (1984), an obvious depression of density and biomass values was noted at the three upper sites in comparison with values at the reference site in Grassy Creek. At the same time, values at BCK 3.25 were greater than at the reference site, suggesting that the impacts were limited to the upper reaches of Bear Creek. In 1985, biomass and density were lower than those of the reference sites only at the uppermost site, BCK 12.36. The next two downstream sites appeared to recover with values exceeding those of the reference sites. As in 1984, no impacts on density or biomass were observed at sampling sites farther downstream on Bear Creek.

The pattern established in 1985 continued through 1986 and 1987 (Figs. 4-1 and 4-2); only the uppermost site in Bear Creek reflected any adverse impacts and many sites exceeded the biomass and density found in reference streams. Occasionally, the impact of low water was evident at BCK 11.09 (e.g., low biomass recorded in the summer of 1985 and fall of 1987). This area of Bear Creek was dry during low-flow periods (Fig. 2-4), but recovery of the fish populations was usually evident by the following sampling period. Fish biomass and density were often higher in Bear Creek than in reference streams at comparable sampling dates. Whether these high values were a result of a more stable environment (constant flow and regulated thermal regime) associated with groundwater input from springs to Bear Creek or because of the limited fish community (e.g., lack of piscivores) is not known.

Total densities were usually highest at BCK 7.87 or 9.40 with the maximum value of $5.97 \mathrm{fish} / \mathrm{m}^{2}$ occurring at $\mathrm{BCK} 9.40$. The lowest density was observed at BCK 12.36 where values ranged from 0 to $0.29 \mathrm{fish} / \mathrm{m}^{2}$. No site was consistently highest in biomass; the highest values were $9.83 \mathrm{~g} / \mathrm{m}^{2}$ at BCK 11.83 in Novernber 1985 and $9.09 \mathrm{~g} / \mathrm{m}^{2}$ at $\mathrm{BCK} 9.40$ in November 1987. The lowest biomass occurred at BCK 12.36 and values were often near or below $0.01 \mathrm{~g} / \mathrm{m}^{2}$.

Contributions of individual species to total densities and biomass were similar for all years. The blacknose dace was the predominant species in density in 33 of 48 possible sampling date-site combinations. Othe: : :edominant species included the creek chub (6 of 48) and Tennessee dace ( 6 of 48 ). The prevalent species based on biomass was 
ORNL-DWG 90-6435
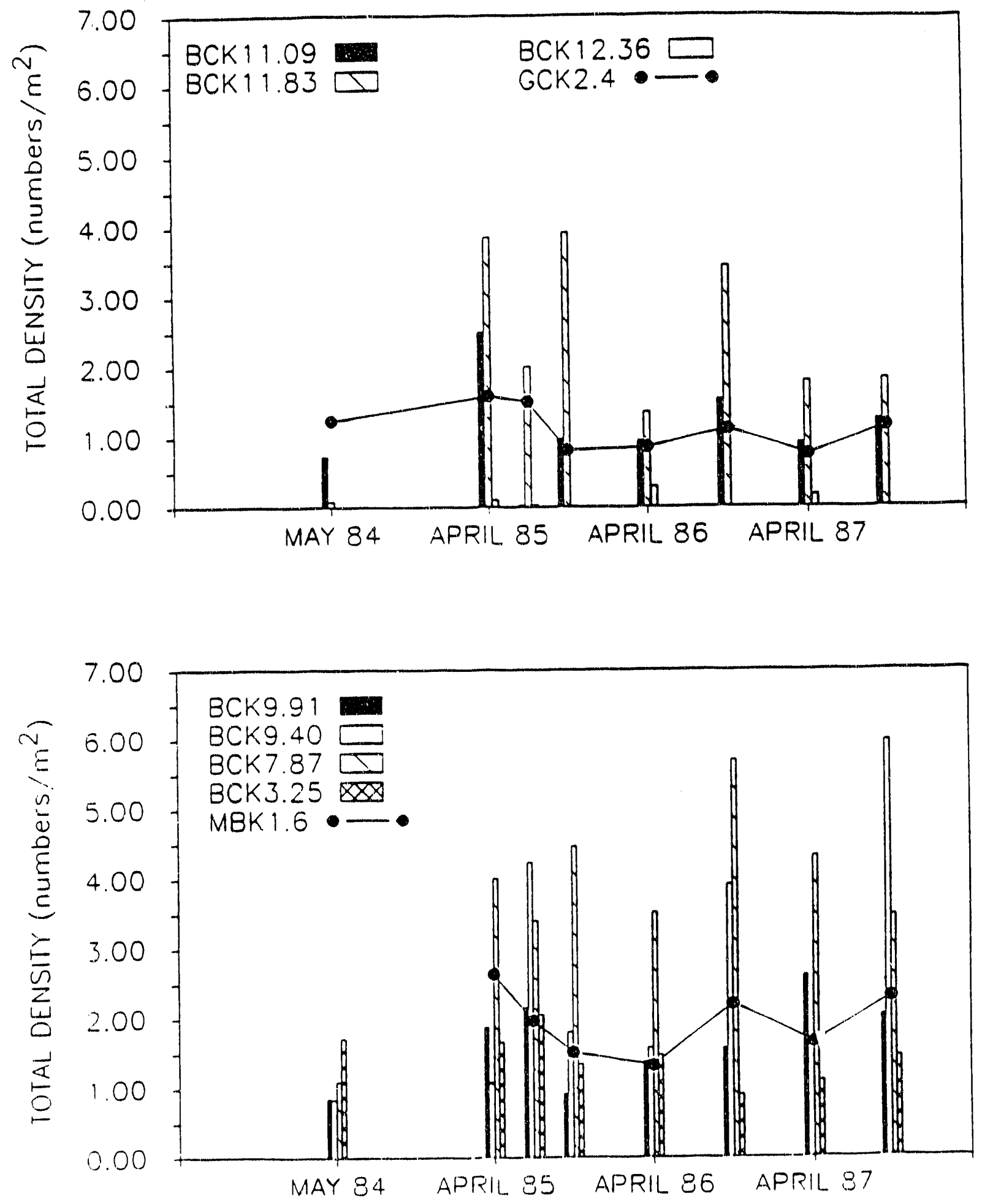

Fig. 4-1. Total fish density (numbers $/ \mathrm{m}^{2}$ ) in Bear Creek, Grassy Creek, and Mill Branch, May 1984-November 1987. 

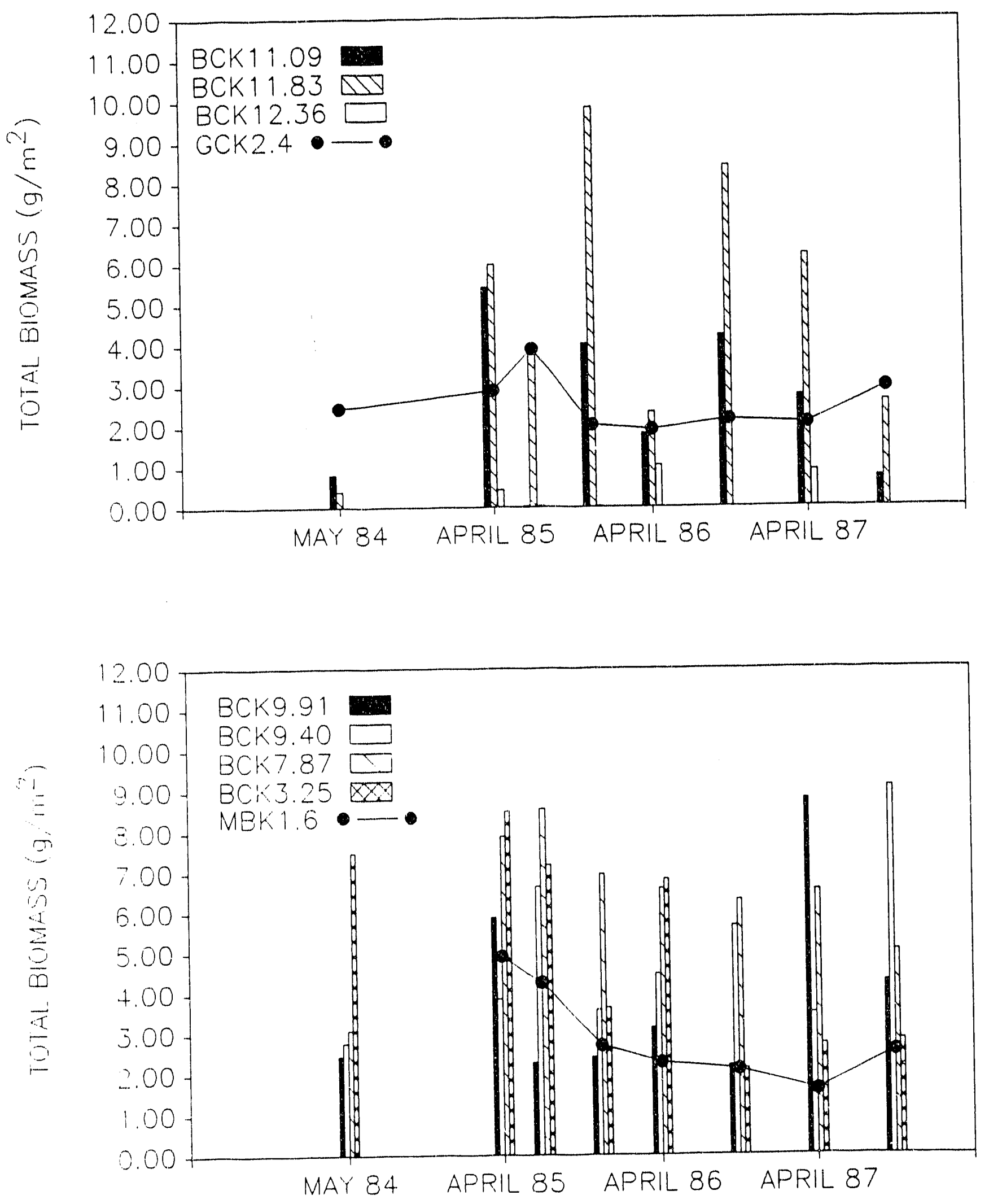

Fig. 4-2, Total fish biomass $\left(\mathrm{g} / \mathrm{m}^{2}\right)$ in Bear Creek, Grassy Creek, and Mill Branch, May 1984-November 1987. 
the creek chub, which had the highest biomass in 26 of 49 possible sampling site-date combinations. Other important contributors to total biomass were the blacknose dace (15 of 49) and stoneroller (6 of 49).

\subsubsection{Condition Factors and Length-Frequency}

Condition factors were calculated for the fish collected in quantitative surveys of Bear Creek and the reference streams from 1985 through 1987, and statistical analyses were conducted to evaluate differences between sites and between sampling periods. Comparisons between sampling periods showed that condition factors in the spring were significantly higher than those in other sampling periods (Appendix C, Table C-1). Of the 30 comparisons with significant differences, condition was highest in one of the spring sampling periods for all but two species/site combinations. This trend indicated the expected preparation for spawning and the absence of young-of-the-year (YOY) at that time of year. Higher condition in the spring was particularly evident in 1987; perhaps indicating an improvement in water quality over the 3 -year period.

Comparisons between sites within a sampling period generally showed no consistent pattern of significant differences (Tables C-2 to C-8). Sites with low biomass, density, and species richness (BCK 12.36 in all years and BCK 11.83 and $B C K 11.09$ in early 1985) did not have significaitly lower condition factors for any species. In fact, individuals at the $\mathrm{BCK} 11.83$ and 11.09 sites often had high condition factors, as was observed previously (J. M. Loar, ORNL/ESD, 1985, personal communication to M. G. Ryon, ORNL/ESD). Such a trend may reflect the influence of spawning movements (increasing the number of large adults in the sample) and the consequences of low flow in upper Bear Creek (reducing the number of very young fish).

Based on the May-June 1984 data set only, the mean condition factor of many fishes was found to be significantly higher at sites in upper Bear Creek, where springs are numerous, compared to the three sites (BCK 7.87, BCK 5.15, and BCK 3.25) farther downstream (J. M. Loar, ORNL/ESD, 1985, personal communication to M. G. Ryon, ORNL/ESD). At that time and with such a limited data set, this finding suggested that springs could enhance fish growth (and thus condition) by providing an 
optimal thermal environment. Examining this hypothesis was important because one of the remedial action alternatives proposed in 1985 for the Bear Creek Valley Waste Disposal Area included the removal and treatment of contaminated groundwater, which has the potential to adversely impact surface flows and temperature in Bear Creek.

To assess the importance of springs on thermal regimes and fish growth, temperature monitoring was initiated in 1985 (Sect. 2.2.3) and sampling was conducted quarterly in 1985 and 1986 to compare fish growth patterns between selected sites. Two abundant species at sites BCK 9.91, BCK 9.40, and BCK 7.87, the blacknose dace and the Tennessee dace, were included in the analysis, which was based on length-frequency plots for three of the quarterly samples collected in 1985 and 1986. Age classes were determined by the length groupings and by the expected growth given in the literature (Becker 1983; D. A. Etnier, University of Tennessee, 1987, personal communication to M. G. Ryon, ORNL/ESD). Length-frequency histograms for blacknose dace showed a general pattern of increasing size of YOY fish from BCK 7.87 upstream to BCK 9.91 (Figs. 4-3, 4-4, and 4-5), but the same trend was not evident for the older age classes. Differences in the mean length between sites for each of the three sampling periods was not statistically significant $(p>0.05)$, even for YOY fish (Fig. 4-6). Similar trends were also observed for the Tennessee dace, but their lower abundance precluded any statistical analysis.

The biological significance of these growth patterns is unclear. Intuitively, smaller sizes might be predicted at the site with the greatest environmental variability (BCK 9.91), and better growth expected at the site with more stable flow and temperature regimes (BCK 9.40). Figure $4-3$ shows that YOX are smaller at BCK 9.91, but only in July/August. Whether these data reflect actual differences in growth rates is not known. However, the influence of springs on fish growth and condition is probably not as great as that hypothesized in 1985. More recent data indicate that most differences in fish condition factors are not statistically significant and the effects of springs on water temperatures in Bear Creek are highly localized (Sect. 2.2.3). 

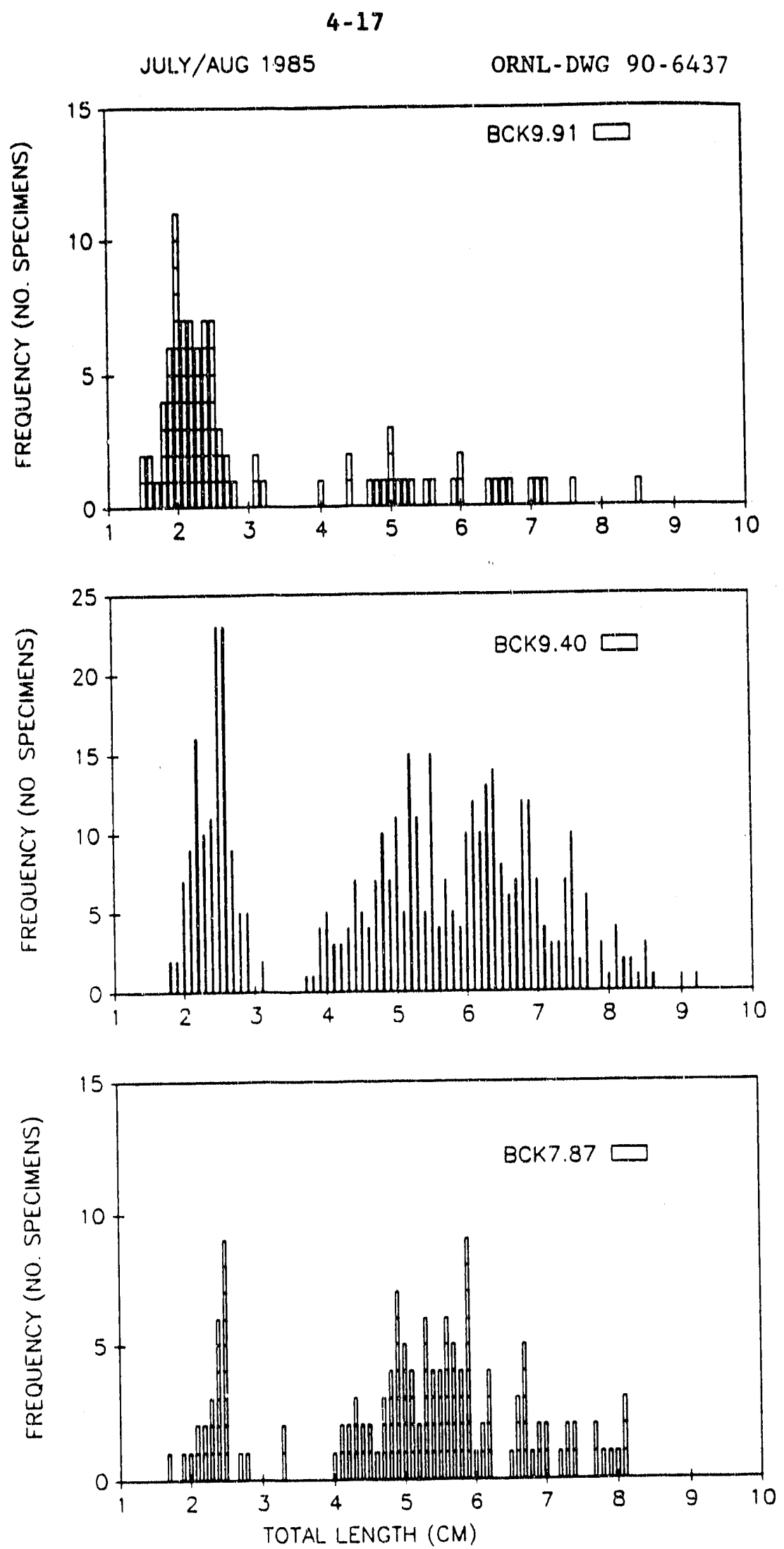

Fig. 4-3. Length-frequency of blacknose dace at Bear Creek (BCK) sites above and below the SS5 spring (at BCK 9.41) during July/August 1985 . 

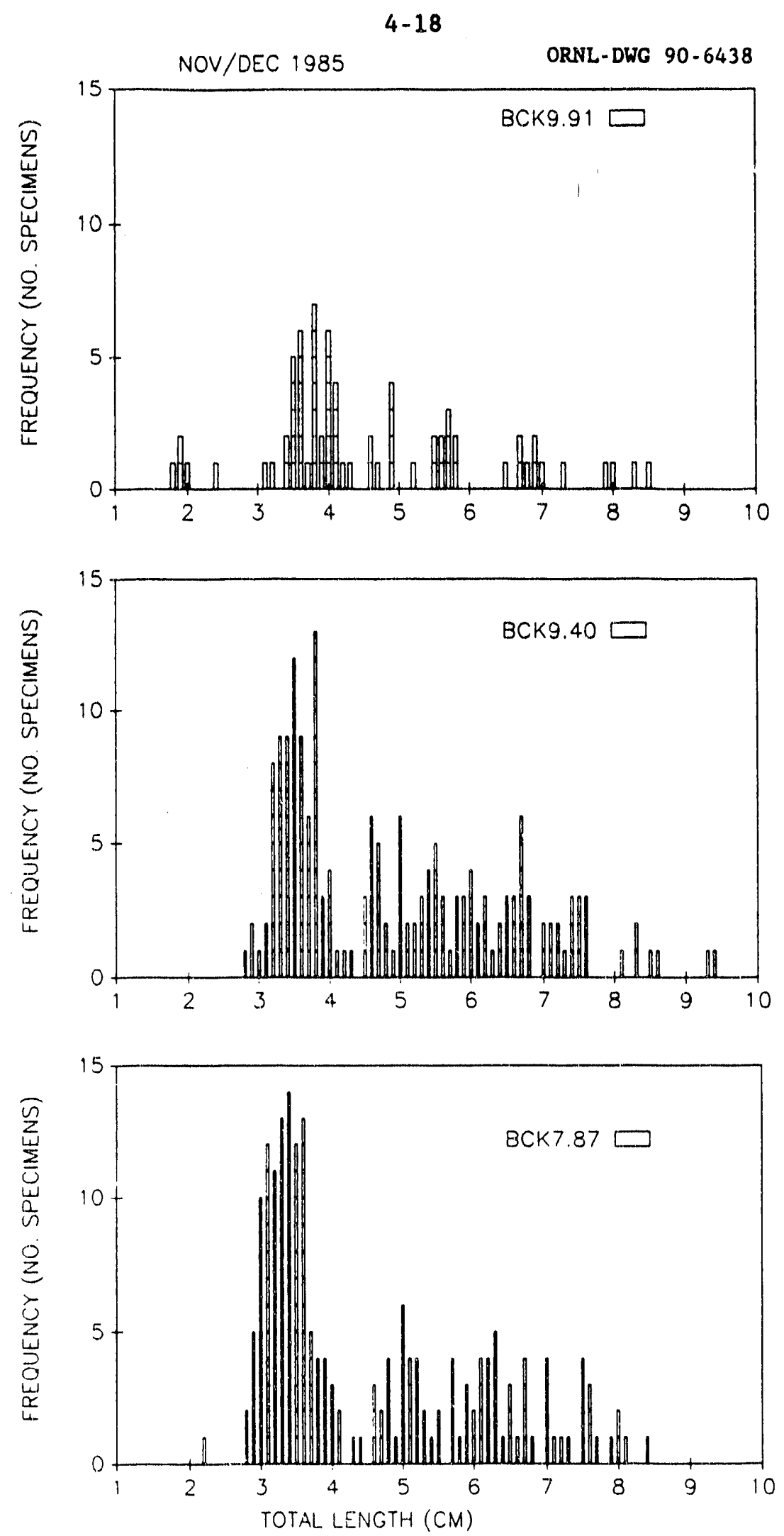

Fig. 4-4. Length-frequency of blacknose dace at Bear Creek (BCK) sites above and below the SS5 spring (at BCK 9.41) during November/December 1985. 

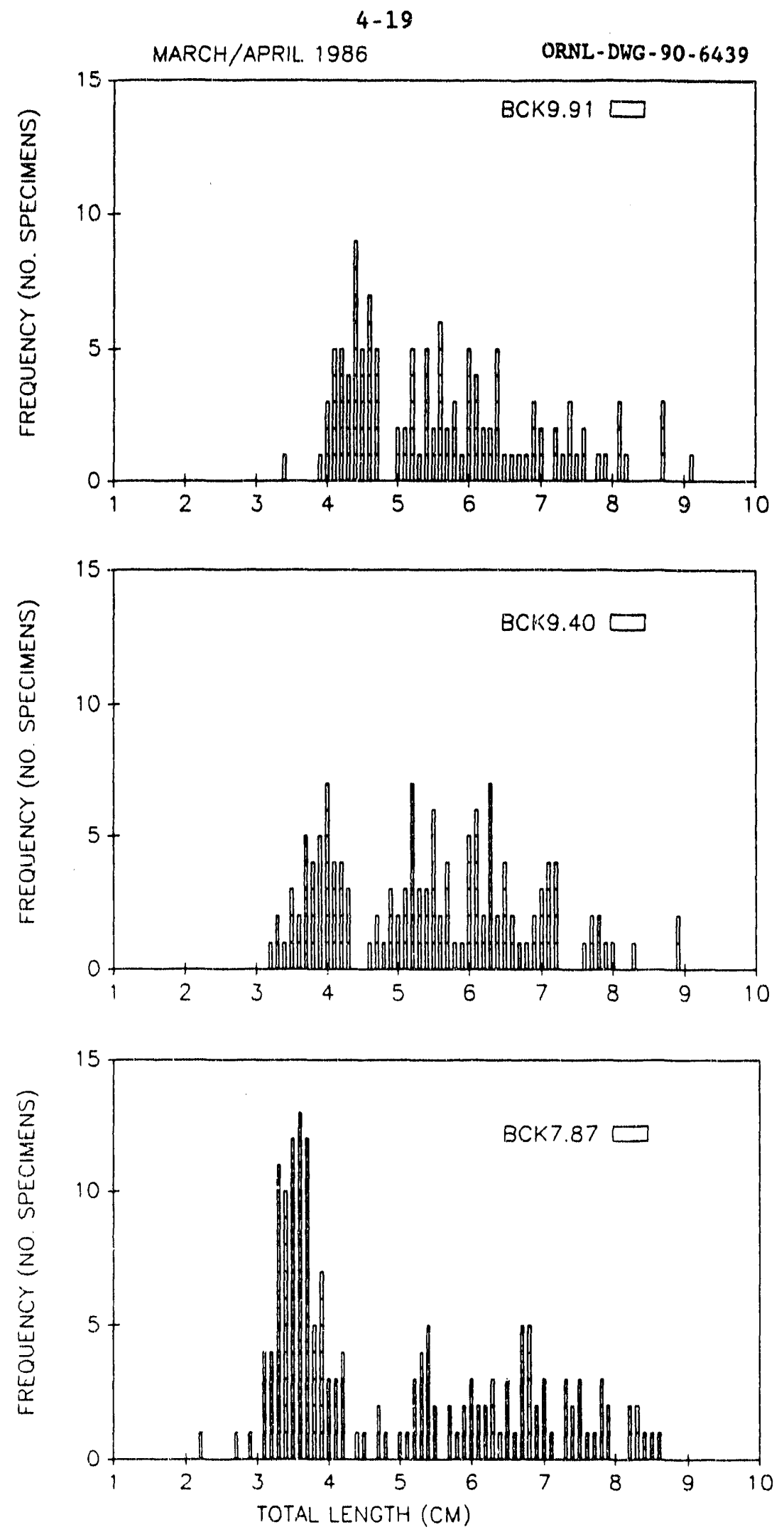

Fig. 4-5. Length-frequency of blacknose dace at Bear Creek (BCK) sites above and below the SS5 spring (at BCK 9.41) during March/April 1986. 

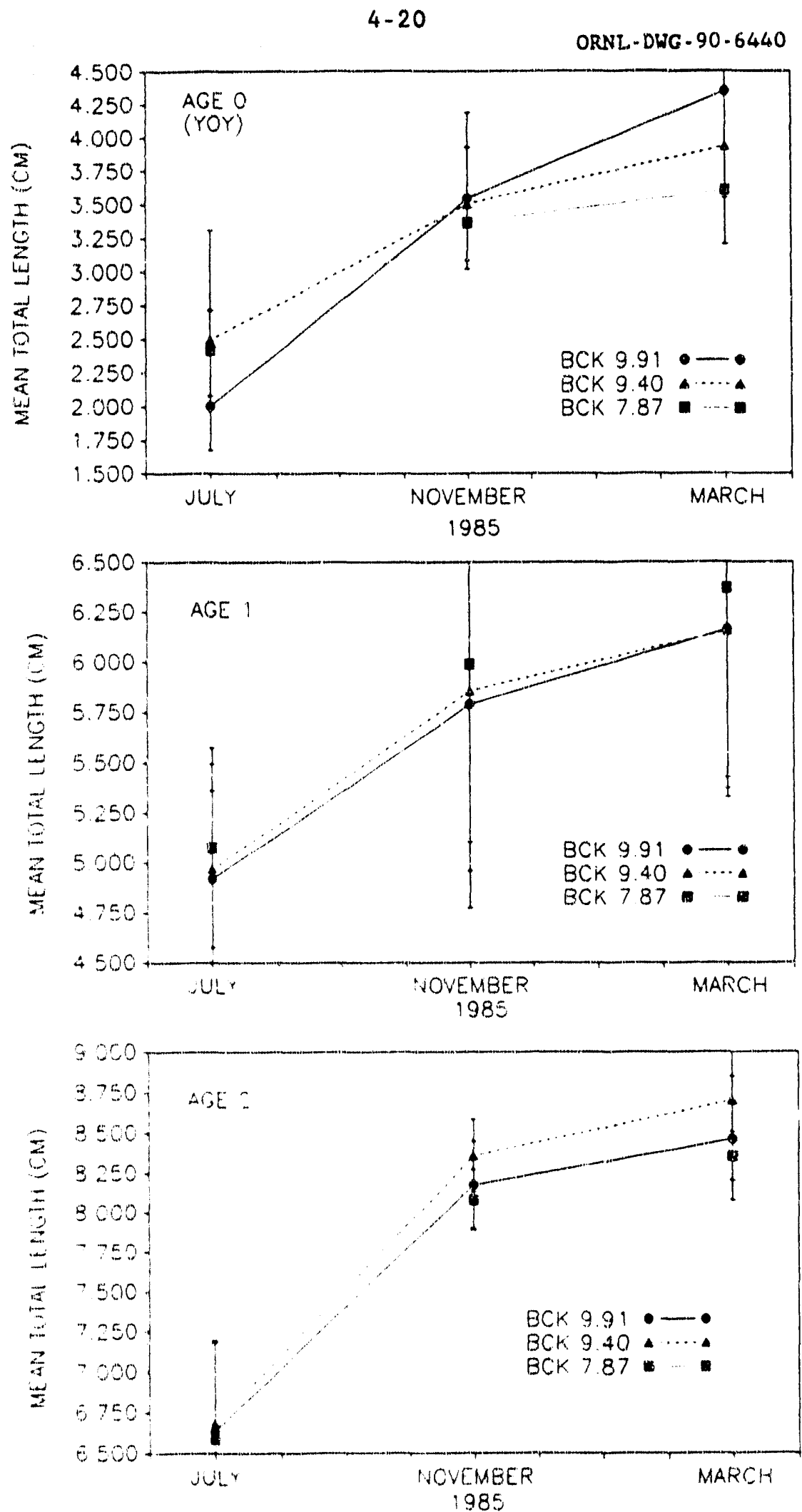

Fig. 4-6. Change in mean length (cm) of three age classes of blacknose dace at Bear Creek (BCK) sites above and below the SS5 spring (at BCK 9.41) during July 1985 to March 1986. Age class determination was based on length-frequency histograms. 


\subsection{CONCLUSTONS}

The 4-year data set included in this report was designed to characterize the fish populations of the Bear Creek watershed and to Indicate any changes resulting from remedial actions. In general, the data indicate that much of Bear Creek had a limited fish fauna (low species richness) that appeared to have robust populations (high densities and biomass). The fish surveys at the uppermost site, BCK 12.36, demonstrated a stressed condition without a stable, resident fish population.

Analyses of the trophic structure of the fish community in Bear Creek indicated that most sites had simple communities with only one herbivore and, except for the lowermost site at BCK 3.25 , no piscivorous predators. The communities were dominated by tolerant species; intolerant species were limited to BCK 3.25 or sites near springs. The ability of intolerant species to provide an additional measure of change in Bear Creek in the future appears limited primarily because of the weir at $\mathrm{BCK} 4.55$, which acts as a barrier separating upper Bear Creek from streams with better water quality in the Clinch River drainage. One important aspect of the fauna of Bear Creek above the weir is the distribution and abundance of the Tennessee dace. This dace is listed as a species in need of management and its habitat is protected by the state of Tennessee (Starnes and Etnier 1980). It occurs at every site above the weir and is an important density and biomass component of populations at several sites. The dace also is found in several tributaries to Bear Creek, including NT13, NT14, ET3, and WT1.

The data on fish population density and biomass exhibit trends similar to those that were first observed in May-June 1984 and trends that indicate significant changes have occurred. For example, fish abundance at BCK 12.36 from 1985 to 1987 was similar to that observed in 1984; significant impacts on the fish population were evident. These appear to be related to the proximity of the site to the $s-3$ ponds, perhaps because of a toxic effect or as a result of habitat destruction from sedimentation. Two sites with low biomass and density in 1984 , $B C K 11.83$ and $B C K$ 11.09, showed recovery the following year. Fish 
populations in these areas did not appear to be substantially impacted by the S-3 pond groundwater plume or discharges, if any, from the oil. landfarm and sanitary landfill. However, BCK 11.09 is adversely affected by low flows as indicated by the low biomass and density in the summer of 1985 and the low biomass in the fall of 1987 . The next sites downstream, BCK 9.91 and BCK 9.40, also showed no significant impact even though they are downstream of several tributaries that drain the burial grounds. The lack of population effects is somewhat surprising because qualitative surveys in 1984-1987 indicate no fish inhabited these streams, which had observable sedimentation and oil films.

Condition factors of all species were significantly higher in the spring sampling periods and represented spawnirig preparation as well as winter mortality of some YOY. Little else could be determined from the analysis of fish condition factors. Between-site comparisons show no pattern of stressed sites that parallels the biomass, density, and richness data. Length-frequency histograms indicate some differences between sites near SS5, but the ecological significance of these differences is not clear. 


\section{BENTHIC MACROINVERTEBRATES}

\subsection{INTRODUCTION}

Benthic macroinvertebrates are those organisms that are large enough to be seen without the aid of magnification and that live on or in the substrate of flowing and nonflowing bodies of water. With limited mobility and life spans of a few months to more than a year, they are ideal for use in evaluating the ecological effects of effluent discharges to streams ( $P$ latts et al. 1983). Thus, the composition and structure of the benthic community reflects the relatively recent past and can be considerably more informative than methods that rely solely on water quality analyses, which ignore the potential synergistic effects that can be associated with complex effluents.

The objectives of the benthic macroinvertebrate study were (1) to provide detailed characterization (spatial and temporal) of the benthic macroinvertebrate community of Bear Creek during the first year (i.e., June 1984-May 1985) and (2) to present the results obtained to date for the monitoring phase of the study. These data will in turn be used to assist in the identification and prioritization of contaminant sources and in the assessment of the effectiveness of major remedial actions designed to mitigate the impacts of past waste disposal operations in Bear Creek Valley.

\subsection{MATERIALS AND METHODS}

Study sites and sampling frequencies for the benthic macroinvertebrate studies are listed in Table 5-1. During the first. year, sampling was conducted monthly from June through October, in December, and monthly from February through May at nine sites in Bear Creek (Figs. 1-1 and 1-2). In addition, three reference sites on Grassy Creek (Fig. 2-7), a small watershed adjacent to and west of Bear Creek Valley, were sampled on the same schedule. During the second and third years of the study (October 1985-July 1987), seven sites in Bear Creek and one site in Grassy Creek were sampled at quarterly intervals. Because of the low survival of fathead minnow larvae in the initial bioassays of water collected from Grassy Creek (Table 3-5), 
Table 5-1. Sampling sites and schedule for benthic macroinvertebrate collections in Bear Creek and reference streams. Year $1=$ June 1984-May 1985, Year $2=$ October 1985-July 1986, Year $3=$ October 1986-July 1987. NS = Not sampled

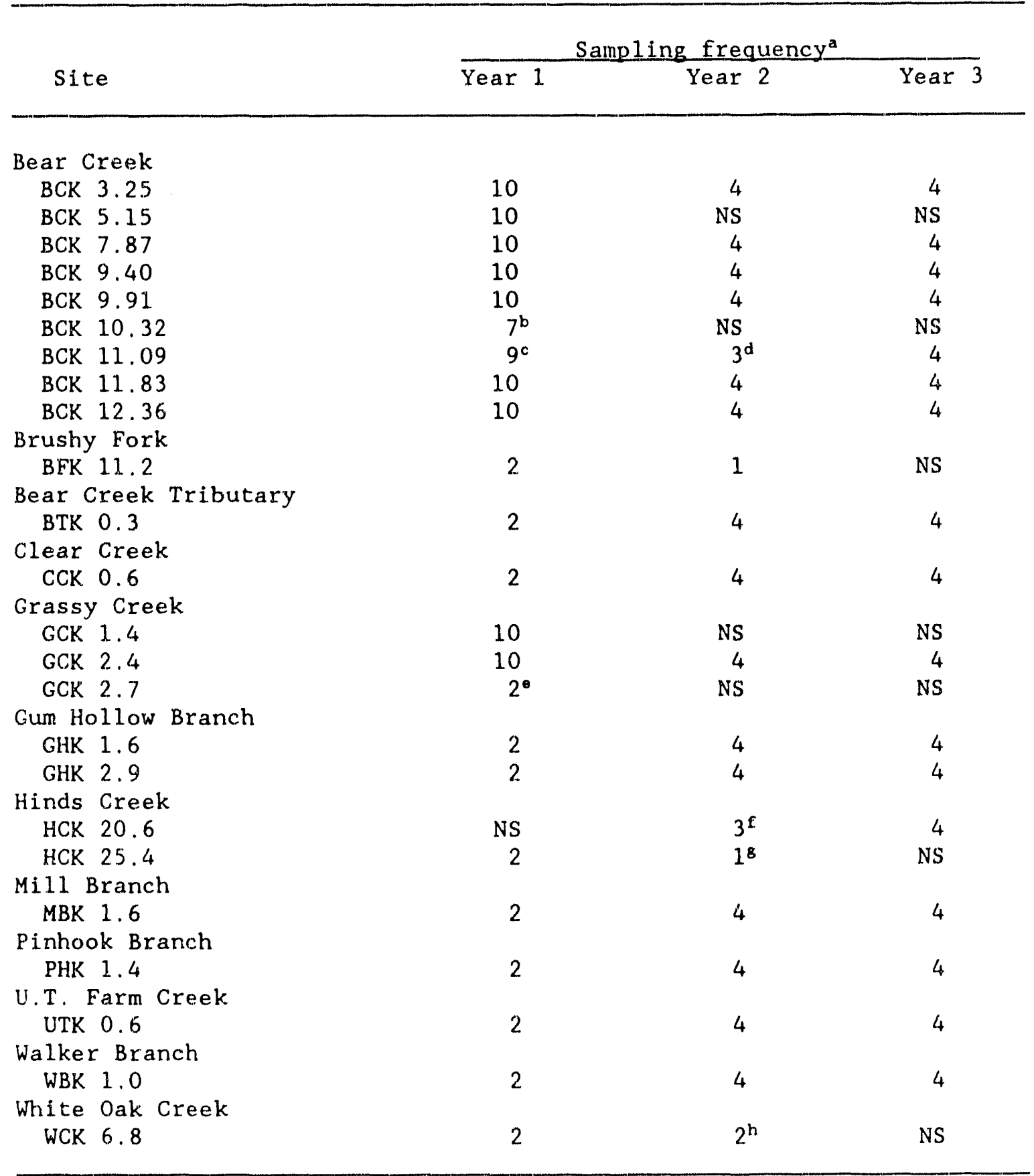

${ }^{a}$ Number of months sampled.

bsite dry in June, August, and September 1984.

'Site dry in September 1984.

dsite dry in July 1986.

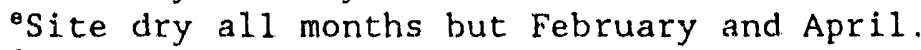

${ }^{f}$ Sampling initiated in January 1986.

Sampled only in October 1985.

${ }^{\mathrm{h}}$ Sampled in October 1985 and January 1986 only. 
several additional reference sites were identified and sampled in October 1984, Apri1 1985, and quarterly from October 1985 through July 1987 (Table 5-1 and Figs. 2-7 and 2-8). Both small and large reference streams were selected to reflect differences in size (width and depth) between sites in the headwaters and those in the lower reaches of Bear Creek. The use of multiple reference sites maintains the integrity of long-term studies such as this one by minimizing the consequences should a presently unimpacted site be disturbed in the future. In addition, such a strategy probably provides a broader basis for examination of long-term changes in the stream of interest because species composition of benthic communties may vary widely between watersheds. Intensive sampling of a single watershed would not provide an accurate estimate of this variability in community structure between streams.

From June 1984 through May 1985, three randomly selected benthic macroinvertebrate samples were collected from riffles at each Bear Creek and Grassy Creek site with a Surber bottom sampler $\left(0.09 \mathrm{~m}^{2}\right.$ or $1 \mathrm{ft}^{2}$; 363 -micron-mesh net). Five samples in October 1984 and three samples in April 1985 were collected in the same manner from each of the additional reference sites. Beginning with the quarterly sampling program in October 1985, Eive randomly se? ected samples were collected in a similar manner from each site, including those on Beax Creek and the reference streams. However, because one reference site on Hinds Creek, HCK 20.6, is also used as a reference for East Fork Poplar Creek (EFPC), samples were collected at this site with a modified Hess sampler $\left(0.1 \mathrm{~m}^{2}\right.$; 363 -micron-mesh net).

To obtain a more complete estimate of species richness within each site, qualitative samples were taken from riffle and nonriffle habitats (e.g., pools, riffles, leaf packs, detritus, snags, etc.) of each site with a D-frame aquatic dip net (mesh of $800 \times 900$ microns). Qualitative samples were washed and concentrated in the field using a small hand net ( 363 micron-mesh) and white photographic tray. During the first year of the study, qualitative samples were collected from Bear Creek and Grassy Creek in May 1985; qualitative samples were not collected from the other reference sites. In subsequent years, qualitative samples 
were taken once a year from all sites during the spring (March/April). Both quantitative and qualitative samples were placed in pre-labeled glass jars and preserved in 808 ethanol; the ethanol was replaced with fresh ethanol within one week.

Various supplenental information was also recorded at the time of sampling. Water temperature and specific conductance were measured with a Cole-Parmer Model R-1491-20 LCD temperature/conductivity meter. Water depth, location within the riffle area (distance from permanent headstakes on the stream bank), relative current velocity (very slow, slow, moderate, or fast), and substrate type based on a modified Wentworth particle size scale (Loar 1985) were recorded for each sample. Stage height at the NPDES monitoring station on Bear Creek (BCK 4.55) was also measured at the beginning of each day samples were collected from Bear Creek.

A11 samples were washed in the laboratory in a standard no. 60 mesh (250-micron-mesh) sieve, and then placed in a white tray. Organisms in samples collected from June 1984 through May 1985 were removed from the debris with forceps without the aid of magnification, while organisms in samples collected in succeeding years were removed with the aid of a magnifled (2X) illuminator. All organisms were placed in labeled vials containing 708 ethanol. Organisms were identified to the lowest practical taxonomic level using a stereoscopic dissecting microscope. After chironomid larvae were sorted into groups based on morphological similarities, one or more representatives of each group were mounted on a slide in CMC-10 mounting media and identified with a compound microscope. The remaining larvae were then identified at a magnification of 80 to $120 \mathrm{X}$ with a dissecting microscope. A blotted wet weight of all individuals in each taxon was determined to the nearest $0.01 \mathrm{mg}$ on a Mettlex analytical balance.

Slides of mounted chironomid larvae were retained in slide boxes, and individuals of the remaining taxa from a given site and sampling date were preserved in separate vials in $80 \%$ ethanol. A reference collection, for which the identification of each taxon has been verified, is maintained at ORNL. 
A11 statistical analyses were done using SAS $(1985 a, b)$. The Shannon-Wiener index $\left(H^{\prime}\right)$ was used to calculate the taxonomic diversity of benthic macroinvertebrates at each site (Pielou 1977):

$$
\mathrm{H}^{\prime}=-\Sigma \mathrm{P}_{\mathrm{j}} \log _{2} \mathrm{P}_{\mathrm{j}},
$$

where $p_{j}$ is the proportion of the benthic invertebrate community made up by species $\mathrm{j}$. Values of $\mathrm{H}^{\prime}\left(\log _{2}\right)$ of 3 or greater are generally associated with unpolluted waters, while values of 1 to 3 are found in areas of moderate pollution, and values of less than 1 are found in heavily polluted water (Platts et al. 1983).

For statistical comparisons, data were transformed $\left[\log _{10}(X+1)\right.$, where $X$ = individual values for density, biomass, diversity, or species richness] (Eliott 1977). Mean values for density, biomass, number of taxa (species richness), and diversity of the Bear Creek sites were compared using a one-way ANOVA with site as the main effect. Similarly, values of these same parameters for the reference sites were compared with each other and then with each Bear Creek site. The maximum amount of data available for each site was used in the comparisons. Where data were missing, only data from the same sampling periods were compared. For example, BCK 11.09 was dry in July 1986, so comparisons with this site in the second year were made only with data from October 1985 and January and April 1986. Significant differences $(\alpha=0.05)$ were identified with Tukey's studentized range test.

\subsection{RESULTS}

\subsubsection{Taxonomic Composition}

One hundred seventeen distinguishable taxa were collected in quantitative samples from Bear Creek during the first year, and 111 and 126 distinguishable taxa were collected in years 2 and 3 , respectively (Appendix D, Table D-1). Many of the organisms that were commonly found in unpolluted reference streams both on and off the Department of Energy ORR (Table D-1; Appendix E, Table E-1) were also found in Bear Creek, including crustaceans (Isopoda, Amphipoda, and Decapoda), aquatic worms (Oligochaeta), snails (Gastropoda), mussels (Pelecypoda), and insects 
(Insecta). Eleven orders of insects were collected from Bear Creek including Collembola (springtails), Ephemeroptera (mayflies), Odonata (dragonflies and damselflies), Orthoptera (crickets and grasshoppers), Plecoptera (stoneflies), Hemiptera (true bugs), Megaloptera 'alderflies and fishflies), Trichoptera (caddisflies), Lepidoptera (butterflies and moths), Coleoptera (beetles), and Diptera (true flies). As in the reference streams, the most commonly collected and diverse group of: organisms collected in Bear Creek were insects of the order Diptera. Most of the dipterans were of the family Chironomidae (true midges) which had 50, 45, and 47 representative taxa in years 1,2 , and 3 , respectively. Particularly notable during all three years was the increasingly sparse occurrence or absence of many taxa with increasing proximity to the Y-12 Plant, especially at sites upstream of BCK 9.40. For example, the number of mayfly taxa collected at BCK 3.25, the lowermost site, was similar to the number collected at many of the reference sites during all three years, but very few mayfly taxa were collected above this site.

In qualitative samples, an additional three taxa, representing two orders, Odonata and Coleoptera, were collected from Bear Creek during the first year (Tables D-1 and E-1). In the second year, an additional seven taxa were collected, representing six orders, including Decapoda, Ephemeroptera, Odonata, Trichoptera, Coleoptera, and Diptera. In the third year, only two additional taxa were collected and both were members of the order Odonata. No additional taxa were collected in qualitative samples from the reference sites during the first year, but in the second year, an additional 16 taxa were collected and included representatives of 7 insect orders (Ephemeroptera, Odonata, Plecoptera, Hemiptera, Trichoptera, Coleoptera, and Diptera). An additional six taxa, representing the four insect orders of Ephemeroptera, Odonata, Plecoptera, and Diptera, were collected in the third year. 


\subsubsection{Density and Blomass**}

\subsubsection{Temporal and Spatial Patterns}

Mean density and biomass of the benthic macroinvertebrates at each sampling site in Bear Creek and the reference sites are presented in Table 5-2. For comparisons with the reference sites during the first year, means of values from October 1984 and April 1985 are also presented in this table. During the first year of the study, there was a general trend of increasing density and biomass with increasing distance from the Y-12 Plant. The highest mean annual density ( 104.6 individuals $/ 0.1 \mathrm{~m}^{2}$ ) was observed at $\mathrm{BCK} 9.40$, while the lowest mean density (2.4 individuals/0.1 $\mathrm{m}^{2}$ ) was observed at BCK 12.36. Likewise, the highest mean annual biomass ( $441.5 \mathrm{mg}$ wet wt $/ 0.1 \mathrm{~m}^{2}$, excluding Decapoda and Mollusca) occurred at BCK 9.40 and the lowest mean biomass $\left(0.7 \mathrm{mg}\right.$ wet wt $\left./ 0.1 \mathrm{~m}^{2}\right)$ was found at BCK 12.36. With the exception of BCK 3.25, decapod.s and mollusks contributed little to the total community density; however, their contxibution to biomass at BCK 3.25 , $B C K 5.15, B C K \quad 7.87$, and $B C K 9.91$ was sometimes considerable.

With the exception of BCK 11.09 in year 2 and BCK 12.36 in Year 3 , the same general trend of increasing density and biomass with increasing distance from the Y-12 Plant was observed in Bear Creek during the second and third years of the study (Table 5-2). As was observed in the first year, maximum and minimum mean densities occurred at BCK 9.40 (221.6 individual $\mathrm{s} / 0.1 \mathrm{~m}^{2}$ ) and $\mathrm{BCK} 12.36$ ( 1.6 individuals $/ 0.1 \mathrm{~m}^{2}$ ), respectively, in year 2 . In year 3 , maximum mean density occurred at BCK 9.40 ( 41.2 .6 individuals $/ 0.1 \mathrm{~m}^{2}$ ), while the minimum occurred at BCK 11.83 (60.8 individuals/0.1 $\mathrm{m}^{2}$ ). The substantial increase in mean annual density at $B C K 12.36$ during the third year was due to a single genus of Chironomidae, Acricotopus. The density of this taxon was very high only during the April sampling period ( 532.0 individuals $/ 0.1 \mathrm{~m}^{2}$ ),

\footnotetext{
${ }^{* \star}$ Comparisons between sites in density and biomass have been made both with and without Mollusca (snails and mussels) and Decapoda (crayfish), because these taxa are generally very heavy but numerically unimportant and can thus suppress the importance of weight changes of other organisms. Therefore, unless otherwise noted, trends presented in both spatial and temporal patterns in density include both Decapoda and Mollusca, while trends in biomass exclude these two groups.
} 
Table 5-2. Mean density (muber/0.1 $\mathrm{m}^{2}$ ) and biomass ( $m$ wet wt/0.1 $\mathrm{m}^{2}$ ) of benthic macroinvertebrates in Bear Creek and references sites, June 1986-July 1987. Values in parentheses are +1 SE of the mean.

$M=$ Number of samples collected

\begin{tabular}{|c|c|c|c|c|c|c|}
\hline \multirow[b]{2}{*}{ site } & \multirow[b]{2}{*}{$\begin{array}{l}\text { Sampling } \\
\text { period }^{\mathrm{a}}\end{array}$} & \multirow[b]{2}{*}{$N$} & \multicolumn{2}{|c|}{ Density } & \multicolumn{2}{|r|}{ Biomass } \\
\hline & & & All taxa & $\begin{array}{l}\text { Excluding } \\
\text { decapods \& mollusks }\end{array}$ & All taxa & $\begin{array}{l}\text { Excluding } \\
\text { decapods \& mollusks }\end{array}$ \\
\hline \multirow[t]{2}{*}{ BCK 3.28} & $\begin{array}{l}1 \\
1^{b}\end{array}$ & 30 & $\begin{array}{l}89.5 \\
(15.6) \\
135.5\end{array}$ & $\begin{array}{l}83.4 \\
(15.4) \\
128.8\end{array}$ & $\begin{array}{l}1423.0 \\
(243.0) \\
1491.4\end{array}$ & $\begin{array}{c}360.7 \\
(180.2) \\
434.1\end{array}$ \\
\hline & $\begin{array}{l}2 \\
3\end{array}$ & $\begin{array}{l}20 \\
20\end{array}$ & $\begin{array}{l}(57.6) \\
191.8 \\
(34.1) \\
133.9 \\
(58.0)\end{array}$ & $\begin{array}{l}(58.9) \\
180.2 \\
(33.8) \\
114.5 \\
(55.8)\end{array}$ & $\begin{array}{l}(248.0) \\
2533.5 \\
(446.7) \\
2325.9 \\
(531.7)\end{array}$ & $\begin{array}{c}(157.3) \\
610.9 \\
(218.0) \\
303.9 \\
(103.4)\end{array}$ \\
\hline BCK 5.15 & $\begin{array}{l}1 \\
1^{b}\end{array}$ & $\begin{array}{l}30 \\
6\end{array}$ & $\begin{array}{c}52.6 \\
(12.2) \\
58.1 \\
(0.7)\end{array}$ & $\begin{array}{c}51.9 \\
(12.2) \\
57.9 \\
(0.5)\end{array}$ & $\begin{array}{c}343.9 \\
(90.0) \\
181.7 \\
(5.8)\end{array}$ & $\begin{array}{c}143.0 \\
(50.8) \\
153.5 \\
(153.5)\end{array}$ \\
\hline \multirow[t]{2}{*}{ BCK 7.87} & $\begin{array}{l}1 \\
1^{b}\end{array}$ & $\begin{array}{l}30 \\
6\end{array}$ & $\begin{array}{c}52.7 \\
(14.1) \\
76.8\end{array}$ & $\begin{array}{c}52.3 \\
(14.1) \\
75.9\end{array}$ & $\begin{array}{c}353.5 \\
(100.7) \\
667.8\end{array}$ & $\begin{array}{l}212.5 \\
(86.5) \\
429.7\end{array}$ \\
\hline & $\begin{array}{l}2 \\
3\end{array}$ & $\begin{array}{l}20 \\
19\end{array}$ & $\begin{array}{c}(28.0) \\
89.1 \\
(29.2) \\
151.0 \\
(47.3)\end{array}$ & $\begin{array}{l}(28.2) \\
88.7 \\
(29.2) \\
150.6 \\
(47.4)\end{array}$ & $\begin{array}{c}(389.2) \\
321.8 \\
(90.4) \\
534.0 \\
(242.4)\end{array}$ & $\begin{array}{c}(343.5) \\
252.0 \\
(77.4) \\
484.1 \\
(261.4)\end{array}$ \\
\hline \multirow[t]{2}{*}{ BCK 9.40} & $\begin{array}{l}1 \\
1^{b}\end{array}$ & $\begin{array}{l}30 \\
6\end{array}$ & $\begin{array}{l}104.6 \\
(26.6) \\
122.0\end{array}$ & $\begin{array}{l}104.5 \\
(26.6) \\
129.8\end{array}$ & $\begin{array}{c}453.9 \\
(181.4) \\
503.9\end{array}$ & $\begin{array}{c}441.5 \\
(180.0) \\
497.2\end{array}$ \\
\hline & $\begin{array}{l}2 \\
3\end{array}$ & $\begin{array}{l}19 \\
20\end{array}$ & $\begin{array}{l}(28.7) \\
221.6 \\
(56.4) \\
412.6 \\
(61.2)\end{array}$ & $\begin{array}{l}(28.5) \\
221.3 \\
(56.4) \\
412.2 \\
(61.1)\end{array}$ & $\begin{array}{c}(180.9) \\
636.7 \\
(170.5) \\
914.7 \\
(53.3)\end{array}$ & $\begin{array}{c}(343.5) \\
597.8 \\
(143.1) \\
796.5 \\
(68.5)\end{array}$ \\
\hline \multirow[t]{2}{*}{ BCK 9.91} & $\begin{array}{l}1 \\
1^{b}\end{array}$ & $\begin{array}{l}30 \\
6\end{array}$ & $\begin{array}{l}14.0 \\
(3.3) \\
11.7\end{array}$ & $\begin{array}{l}13.8 \\
(3.3) \\
11.7\end{array}$ & $\begin{array}{c}292.1 \\
(154.7) \\
20.6\end{array}$ & $\begin{array}{c}44.2 \\
(27.0) \\
20.6\end{array}$ \\
\hline & $\begin{array}{l}2 \\
3\end{array}$ & $\begin{array}{l}19 \\
20\end{array}$ & $\begin{array}{c}(3.8) \\
101.2 \\
(39.7) \\
240.9 \\
(167.5)\end{array}$ & $\begin{array}{c}(3.8) \\
100.8 \\
(39.7) \\
240.5 \\
(167.5)\end{array}$ & $\begin{array}{l}(8.6) \\
203.6 \\
(59.4) \\
167.7 \\
(99.2)\end{array}$ & $\begin{array}{l}(8.6) \\
155.5 \\
(67.4) \\
161.6 \\
(98.70)\end{array}$ \\
\hline BCK 10.32 & $\begin{array}{l}1 \\
1^{b}\end{array}$ & $\begin{array}{r}21 \\
6\end{array}$ & $\begin{array}{l}15.4 \\
(4.8) \\
30.3 \\
(5.9)\end{array}$ & $\begin{array}{l}15.3 \\
(4.8) \\
30.1 \\
(6.1)\end{array}$ & $\begin{array}{c}57.7 \\
(32.5) \\
81.0 \\
(71.2)\end{array}$ & $\begin{array}{c}56.8 \\
(32.7) \\
77.9 \\
(74.3)\end{array}$ \\
\hline \multirow[t]{2}{*}{ BCK 11.09} & $\begin{array}{l}1^{1} \\
1^{b}\end{array}$ & $\begin{array}{l}27 \\
6\end{array}$ & $\begin{array}{l}16.7 \\
(5.3) \\
28.0\end{array}$ & $\begin{array}{l}16.6 \\
(5.3) \\
28.0\end{array}$ & $\begin{array}{l}24.7 \\
(9.6) \\
24.3\end{array}$ & $\begin{array}{l}23.1 \\
(9.9) \\
24.3\end{array}$ \\
\hline & 3 & $\begin{array}{l}15 \\
20\end{array}$ & $\begin{array}{c}(16.5) \\
187.9 \\
(103.0) \\
147.0 \\
(102.1)\end{array}$ & $\begin{array}{c}(16.5) \\
184.5 \\
(104.5) \\
146.2 \\
(102.3)\end{array}$ & $\begin{array}{l}(2.3) \\
314.9 \\
(52.7) \\
140.9 \\
(74.7)\end{array}$ & $\begin{array}{l}(2.3) \\
245.0 \\
(33.3) \\
126.0 \\
(79.0)\end{array}$ \\
\hline
\end{tabular}


Table 5-2 (cont inued)

\begin{tabular}{|c|c|c|c|c|c|c|}
\hline \multirow[b]{2}{*}{ Site } & \multirow[b]{2}{*}{$\begin{array}{l}\text { Sampl ing } \\
\text { period }^{\mathrm{a}}\end{array}$} & \multirow[b]{2}{*}{$N$} & \multicolumn{2}{|c|}{ Density } & \multicolumn{2}{|r|}{ Biomass } \\
\hline & & & All taxa & $\begin{array}{l}\text { Excluding } \\
\text { decapods \& moll lusks }\end{array}$ & All taxa & $\begin{array}{c}\text { Excluding } \\
\text { decapods \& mollusks }\end{array}$ \\
\hline BCK 11.83 & $1^{b}$ & $\begin{array}{l}30 \\
6\end{array}$ & $\begin{array}{l}23.0 \\
(9.1) \\
20.1\end{array}$ & $\begin{array}{l}22.9 \\
(9.1) \\
19.9\end{array}$ & $\begin{array}{c}90.5 \\
(68.7) \\
24.3\end{array}$ & $\begin{array}{c}77.0 \\
(69.4) \\
6.4\end{array}$ \\
\hline & $\begin{array}{l}2 \\
3\end{array}$ & $\begin{array}{l}20 \\
20\end{array}$ & $\begin{array}{c}(15.4) \\
31.5 \\
(14.6) \\
60.8 \\
(19.7)\end{array}$ & $\begin{array}{c}(15.2) \\
31.4 \\
(14.6) \\
60.3 \\
(19.7)\end{array}$ & $\begin{array}{c}(23.9) \\
14.1 \\
(4.6) \\
166.5 \\
(95.7)\end{array}$ & $\begin{array}{c}(5.9) \\
13.7 \\
(4.6) \\
152.6 \\
(99.9)\end{array}$ \\
\hline BCK 12.36 & $\begin{array}{l}1 \\
1^{b}\end{array}$ & $\begin{array}{l}30 \\
6\end{array}$ & $\begin{array}{c}2.4 \\
(1.2) \\
1.4\end{array}$ & $\begin{array}{l}2.4 \\
(1.2) \\
1.4\end{array}$ & $\begin{array}{c}3.6 \\
(2.9) \\
0.4\end{array}$ & $\begin{array}{c}0.7 \\
(0.2) \\
0.4\end{array}$ \\
\hline & $\begin{array}{l}2 \\
3\end{array}$ & $\begin{array}{l}20 \\
20\end{array}$ & $\begin{array}{c}(0.7) \\
1.6 \\
(0.6) \\
133.8 \\
(132.7)\end{array}$ & $\begin{array}{c}(0.7) \\
1.6 \\
(0.6) \\
133.7 \\
(132.7)\end{array}$ & $\begin{array}{c}(0.2) \\
0.5 \\
(0.1) \\
22.5 \\
(20.2)\end{array}$ & $\begin{array}{c}(0.2) \\
0.5 \\
(0.1) \\
21.1 \\
(20.6)\end{array}$ \\
\hline BFK 11.2 & 1 & 8 & $\begin{array}{l}104.1 \\
(31.5)\end{array}$ & $\begin{array}{c}97.2 \\
(28.1)\end{array}$ & $\begin{array}{c}3967.0 \\
(1880.2)\end{array}$ & $\begin{array}{c}362.5 \\
(159.0)\end{array}$ \\
\hline BTK 0.3 & $\begin{array}{l}1 \\
2 \\
3\end{array}$ & $\begin{array}{l}8 \\
19 \\
20\end{array}$ & $\begin{array}{l}75.3 \\
(25.2) \\
113.2 \\
(26.7) \\
200.0 \\
(37.6)\end{array}$ & $\begin{array}{l}73.6 \\
(24.3) \\
111.7 \\
(25.9) \\
196.2 \\
(37.6)\end{array}$ & $\begin{array}{c}419.0 \\
(232.4) \\
292.4 \\
(46.4) \\
321.7 \\
(167.0)\end{array}$ & $\begin{array}{c}399.7 \\
(213.3) \\
222.8 \\
(56.3) \\
307.1 \\
(159.0)\end{array}$ \\
\hline CCK 0.6 & $\begin{array}{l}1 \\
2 \\
3\end{array}$ & $\begin{array}{r}8 \\
19 \\
20\end{array}$ & $\begin{array}{l}71.8 \\
(10.0) \\
132.1 \\
(30.7) \\
237.6 \\
(59.5)\end{array}$ & $\begin{array}{l}59.2 \\
(11.8) \\
114.1 \\
(32.4) \\
211.9 \\
(51.4)\end{array}$ & $\begin{array}{l}999.0 \\
(147.1) \\
1586.1 \\
(215.8) \\
1516.9 \\
(427.2)\end{array}$ & $\begin{array}{c}327.5 \\
(159.7) \\
257.6 \\
(92.7) \\
218.3 \\
(58.5)\end{array}$ \\
\hline GCK 1.4 & $\begin{array}{l}1 \\
1^{b}\end{array}$ & $\begin{array}{l}30 \\
6\end{array}$ & $\begin{array}{l}59.3 \\
(5.7) \\
44.9 \\
(4.7)\end{array}$ & $\begin{array}{c}53.2 \\
(6.7) \\
35.7 \\
(11.3)\end{array}$ & $\begin{array}{c}809.2 \\
(224.8) \\
1298.9 \\
(1014.4)\end{array}$ & $\begin{array}{l}280.3 \\
(89.2) \\
212.5 \\
(130.1)\end{array}$ \\
\hline GCK 2.4 & $1^{b}$ & $\begin{array}{r}30 \\
6\end{array}$ & $\begin{array}{l}43.8 \\
(5.3) \\
41.8\end{array}$ & $\begin{array}{l}28.0 \\
(4.2) \\
30.1\end{array}$ & $\begin{array}{l}2158.2 \\
(421.3) \\
1435.7\end{array}$ & $\begin{array}{l}226.0 \\
(42.4) \\
138.0\end{array}$ \\
\hline & $\begin{array}{l}2 \\
3\end{array}$ & $\begin{array}{l}20 \\
20\end{array}$ & $\begin{array}{c}(14.9) \\
76.2 \\
(18.2) \\
141.8 \\
(29.9)\end{array}$ & $\begin{array}{c}(10.8) \\
47.2 \\
(12.2) \\
118.1 \\
(31.5)\end{array}$ & $\begin{array}{c}(316.5) \\
5210.1 \\
(1302.2) \\
3314.7 \\
(774.2)\end{array}$ & $\begin{array}{l}(54.6) \\
219.1 \\
(35.3) \\
290.2 \\
(52.9)\end{array}$ \\
\hline GHK 1.6 & $\begin{array}{l}1 \\
2 \\
3\end{array}$ & $\begin{array}{r}8 \\
18 \\
20\end{array}$ & $\begin{array}{l}73.6 \\
(13.6) \\
107.1 \\
(15.2) \\
166.4 \\
(62.4)\end{array}$ & $\begin{array}{c}72.2 \\
(13.6) \\
96.3 \\
(13.3) \\
158.7 \\
(60.8)\end{array}$ & $\begin{array}{l}588.0 \\
(182.0) \\
2191.2 \\
(317.0) \\
1374.0 \\
(881.9)\end{array}$ & $\begin{array}{c}328.9 \\
(154.5) \\
404.1 \\
(148.2) \\
213.4 \\
(61.0)\end{array}$ \\
\hline
\end{tabular}


Table 5-2 (cont inued)

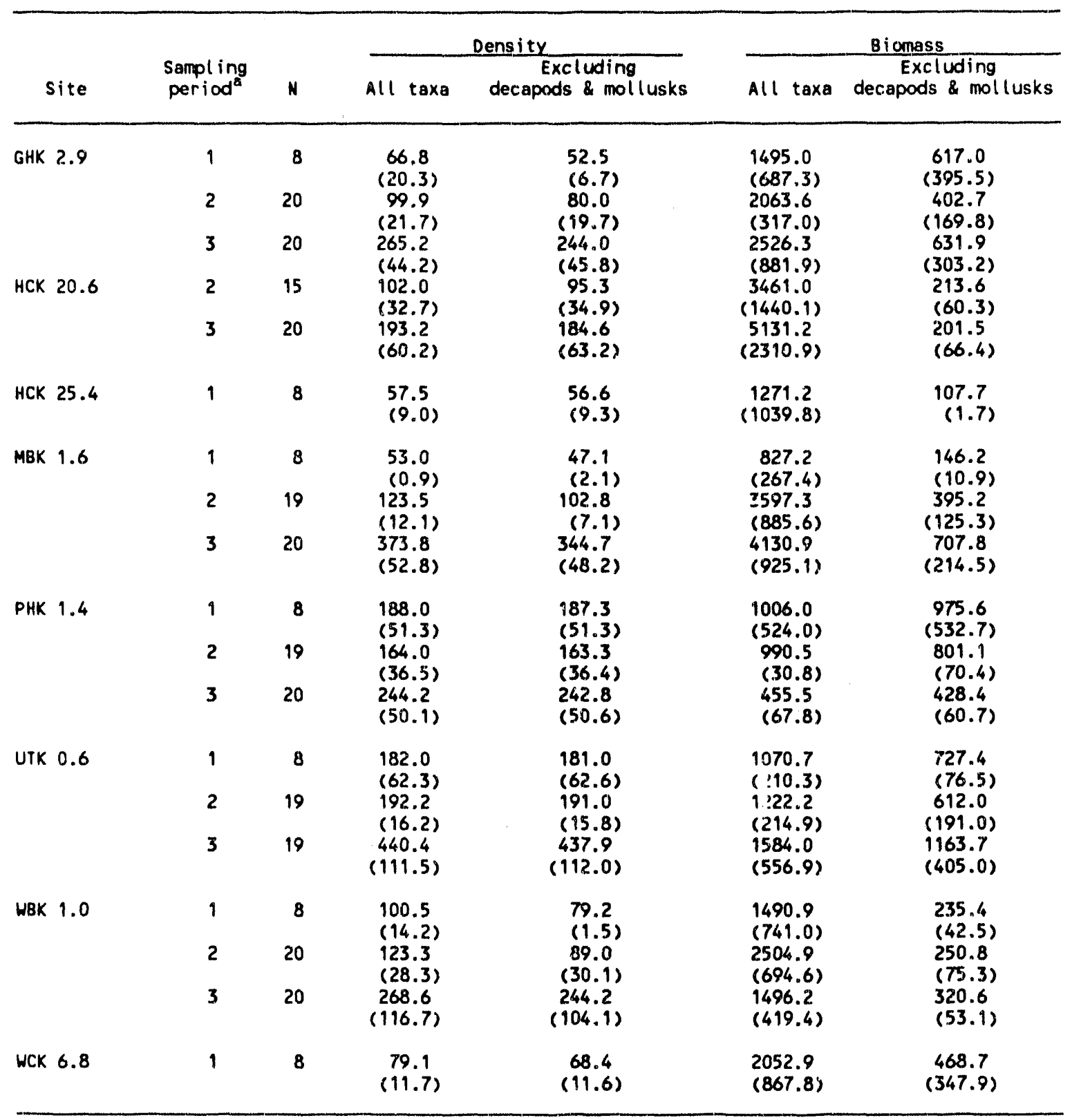

\footnotetext{
${ }^{a}$ Year 1 = June 1984-May 1985; year 2 = October 1985-July 1986; year 3 = October 1986-July 1987.

balues represent oniy samples collected in October 1984 and April 1985, for comparison with reference sites.
} 
whereas total community density at this site during the other three sampling periods of the same year was very low (0.0 to 2.6 individuals $/ 0.1 \mathrm{~m}^{2}$ ). Biomass in Bear Creek was highest during the second and third years at BCK $3.25\left(610.9 \mathrm{mg}\right.$ wet wt $\left./ 0.1 \mathrm{~m}^{2}\right)$ and $B C K 9.40$ (796.5 mg wet wt $/ 0.1 \mathrm{~m}^{2}$ ), respectively, and was lowest in both years at BCK $12.36\left(0.5\right.$ and $21.1 \mathrm{mg}$ wet $w t / 0.1 \mathrm{~m}^{2}$ in years 2 and 3 , respectively). As was found during the first year, decapods and mollusks contributed little to total community density except at BCK 3.25 , and their primary influence on community biomass was generally limited to those sites below SS5.

Statistical comparisons of both density and biomass between Bear Creek sites revealed several significant trends (Appendix F, Tables F-1 and F-2). Density and biomass at those sites above SS5 were generally significantly lower than the density and biomass at sites below the spring. Both parameters were significantly lower at BCK 12.36 compared to other sites in all three years and, with few exceptions, were usually significantly higher at BCK 3.25 and/or BCK 9.40 than at all other sites.

The reference sites, 1ike those in Bear Creek, exhibited a considerable range in mean density and biomass. Lowest density was found at GCK 2.4 in all three years and ranged from 41.8 individuals/0.1 $\mathrm{m}^{2}$ in year 1 to 141.8 individuals $/ 0.1 \mathrm{~m}^{2}$ in year 3 (Table 5-2). The highest density in year $1,188.0$ individuals $/ 0.1 \mathrm{~m}^{2}$, was found at PHK 1,4, while in years 2 and 3 , the highest densities were found at UTK 0.6 (192.2 and 440.4 individua $1 \mathrm{~s} / 0.1 \mathrm{~m}^{2}$, respectively). Minimum biomass ranged from $107.7 \mathrm{mg}$ wet wt $/ 0.1 \mathrm{~m}^{2}$ at $\mathrm{HCK} 25.4$ in year 1 to $212.5 \mathrm{mg}$ wet weight $/ 0.1 \mathrm{~m}^{2}$ at $\mathrm{GCK} 2.4$ in year 2 . Maximum biomass (exclusive of decapods and mollusks) values ranged from $801.1 \mathrm{mg}$ wet w/0.1 $\mathrm{m}^{2}$ at PHK 1.4 in the year 2 to $1163.7 \mathrm{mg}$ wet wt $/ 0.1 \mathrm{~m}^{2}$ UTK 0.6 in year 3. At most sites, decapods and mollusks were usually a minor component of community density but a major component of community biomass .

Comparisons of density and biomass between reference sites showed that significant differences occurred between some sites in all years (Tables F-3 and F-4). Although these sites exhibited some differences 
in density and biomass, there were no consistent differences that were indicative of degraded conditions. For example, densities at GCK 2.4 were consistently lower than densfties at most other sites, but few of the differences were statistically significant. This was also true for blomass at BTK 0.3. Excluding decapods and mollusks from the analyses considerably altered the pattern of significant differences in both density and biomass between sites. Such a finding demonstrates that these two groups, but especially mollusks, were important at some sites and not at others.

All Bear Creek sites and reference sites exhibited year-to-year changes in both density and biomass (Tables $5-2$ and F-5 through F-8). rensitfes at all sites in Bear Creek, except BCK 12.36 during years 2 and 3 , tended to be significantly greater than those found during year 1 (Table F-5). However, densities at BCK 3.25 during the first year did not differ significantly from those of succeeding years, nor did densities at BCK 7.87 and BCK 12.36 differ significantly between the fixst and second years. Taking into consideration all sampling periods during the second and third years, densities did not differ significantly between years 2 and 3 at $B C K$ 9.91; were greater during the second year at $B C K 3.25$ and $B C K$ 11.09; and were greater during the third year at BCK 7.87, BCK 9.40, BCK 11.83, and BCK 12.36.

Biomass generally increased from the first to the third year, although the increase was not always significant (Table F-6). Comparisons of years 2 and 3 using data from all sampling periods indicated that biomass in the third year was significantly greater at $B C K$ 9.40, BCK 11.83, and $B C K$ 12.36; significantly lower at BCK 11.09; and not significantly different from the second year at BCK 3.25 , BCK 7.87, and BCK 9.91. Excluding decapods and mollusks from the analysis altered the pattern of signiffcant differences at $B C K 3.25$, $B C K$ 9.40, and BCK 9.9, most likely because of the presence/absence of decapods. Although they occurred in very low densities, their large size could result in a single individual adding several hundred milligrams to the biomass.

The reference sites exhibited year-to-year trends in density simiiar to thcse of Bear Creek (Table F-7). A tendency of increasing 
density from the first to the third year was evident at most sites, although this trend was not always statistically significant. Likewise, densities during the third year tended to be significantly greater than the second year at most but not all sites.

As with denstty, biomass (all taxa included) of the reference streams exhibited annual changes similar to those in Bear Creek (Table F-8). With the exception of BTK 0.3 , biomass generally increased from year 1 to year 3 , but the trends were not always significant. As was found in the analyses of the Bear Creek sites, exclusion of decapods and mollusks altered the pattern of significance at some reference sites, and was also most likely the result of decapods.

Considerable variability occurred from one sampling period to another in both derisity and biomass at most sites in Bear Creek and at all reference sites (Fig; 5-1,5-2,5-3, and 5-4). Although consistently distinct seisonal patterns were not always apparent over the course of three years, peaks in both density and biomass frequently occurred during the spring (Apri1); at a few sites, peaks occurred during the fall sampling periods.

The highest monthly density in Bear Creek (736.5 individuals/0.1 m2) was observed at BCK 9.91 in April 1987 (Fig. 5-1). No individuals were collected in three sampies, two at BCK 12.36 (May 1985 and October 1986), and one at BCK 10.32 (May 1985). Monthly mean densities were frequently at or near 100 individuals/0.1 $\mathrm{m}^{2}$ at $\mathrm{BCK} 3.25, \mathrm{BCK} 7.87$, and $B C K$ 9.40; whereas upstream of SS5, densities were consistently well below 100 individuals $/ 0.1 \mathrm{~m}^{2}$. Although densities were consisterity below 3.0 individuals $/ 0.1 \mathrm{~m}^{2}$ at $\mathrm{BCK} 12.36$, the density at this site in April 1987 was 532.0 individuals $/ 0.1 \mathrm{~m}^{2}$. This high density was almost: entirely because of a single chironomid taxon, Acricotopus, which had not been previously collected at this site.

Exclusive of GCK 2.7, which was dry 8 out of 10 sampling periods during the first year, the lowest observed density in the reference streams was 46.5 individuals/0.1 $\mathrm{m}^{2}$ at GHK 2.9 in October 1984 (Fig. 5-2). The highest density observed in the reference streams was 708.5 individuals $/ 0.1 \mathrm{~m}^{2}$ in April 1987. With the exception of the 

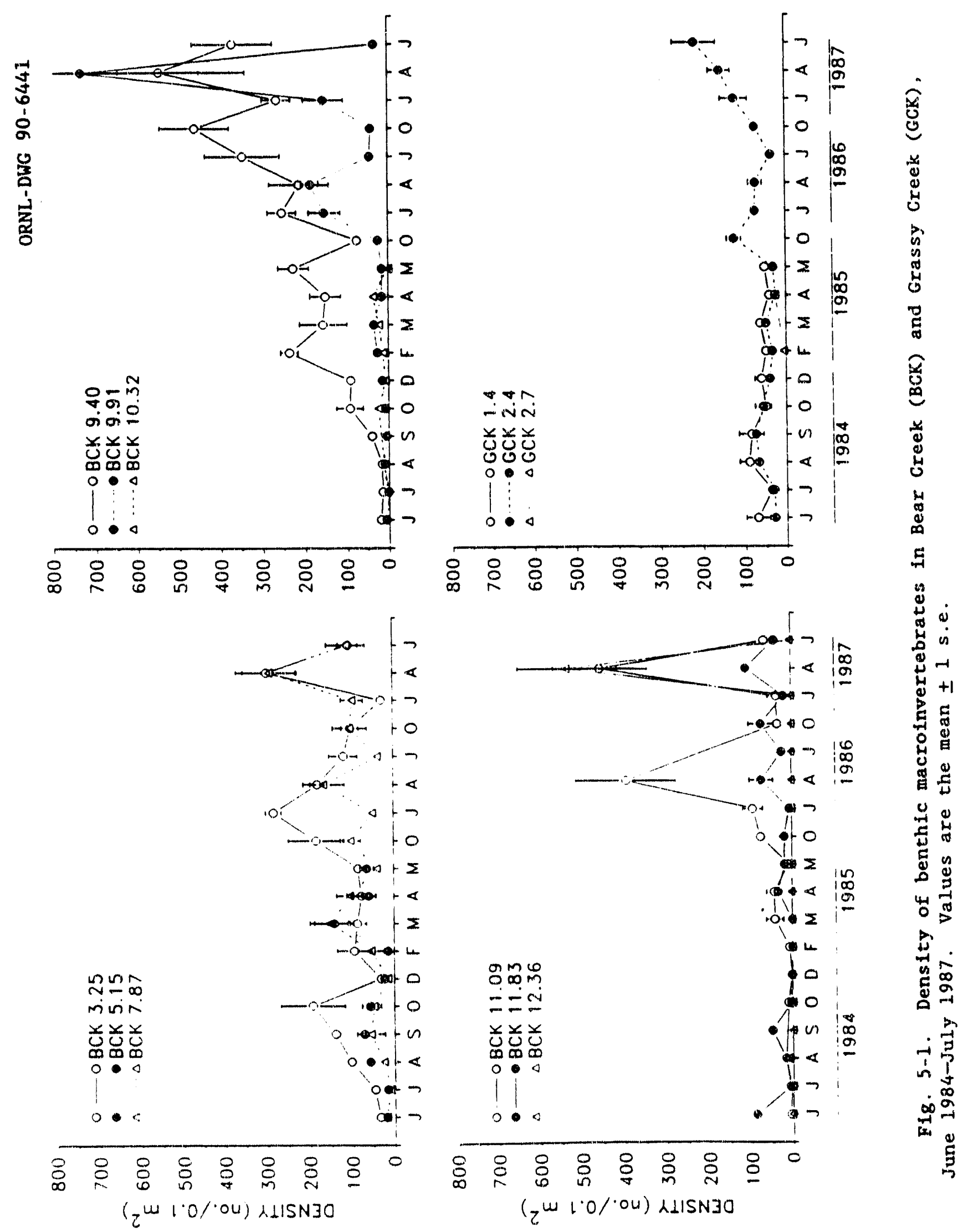


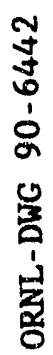

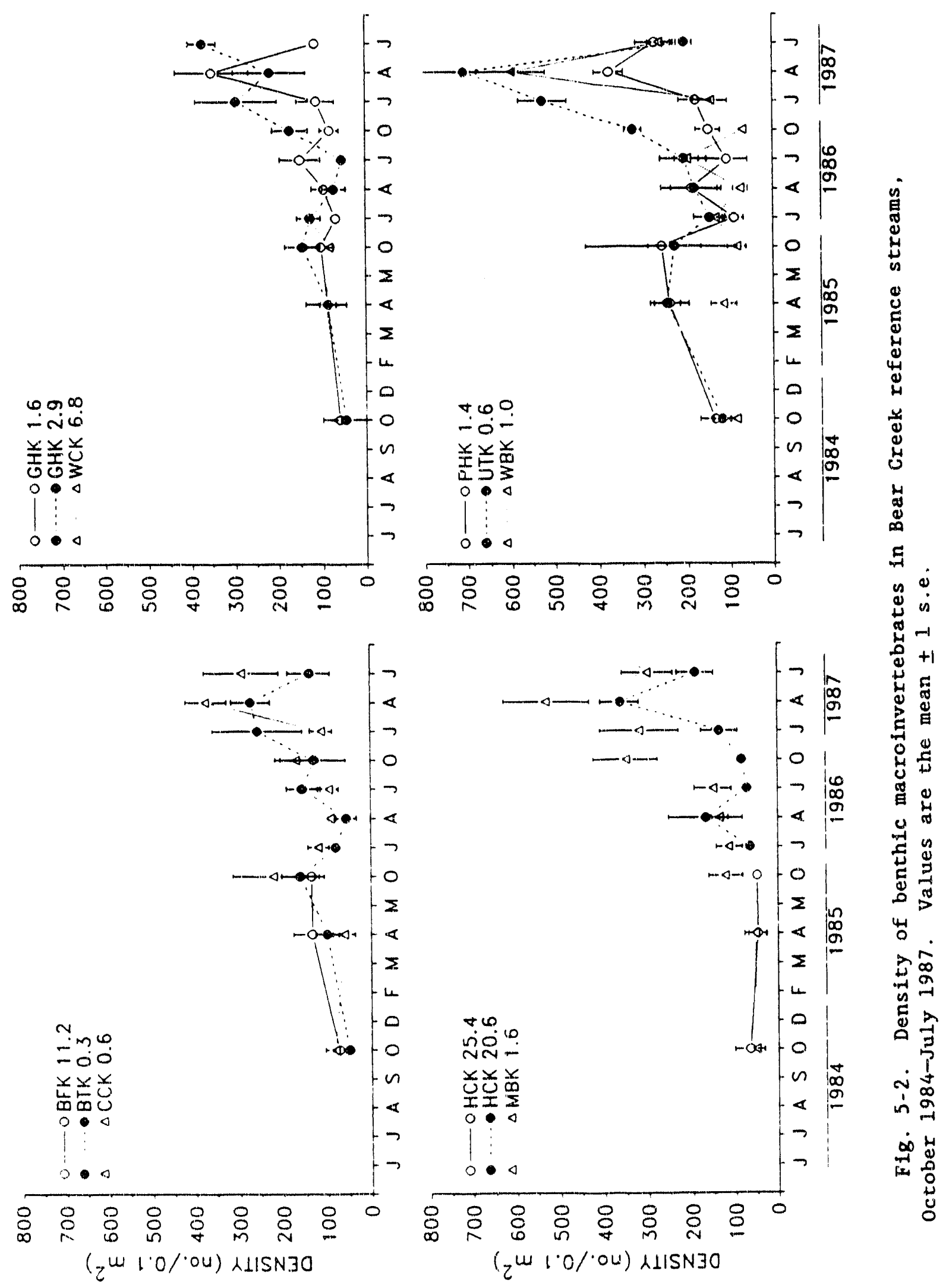



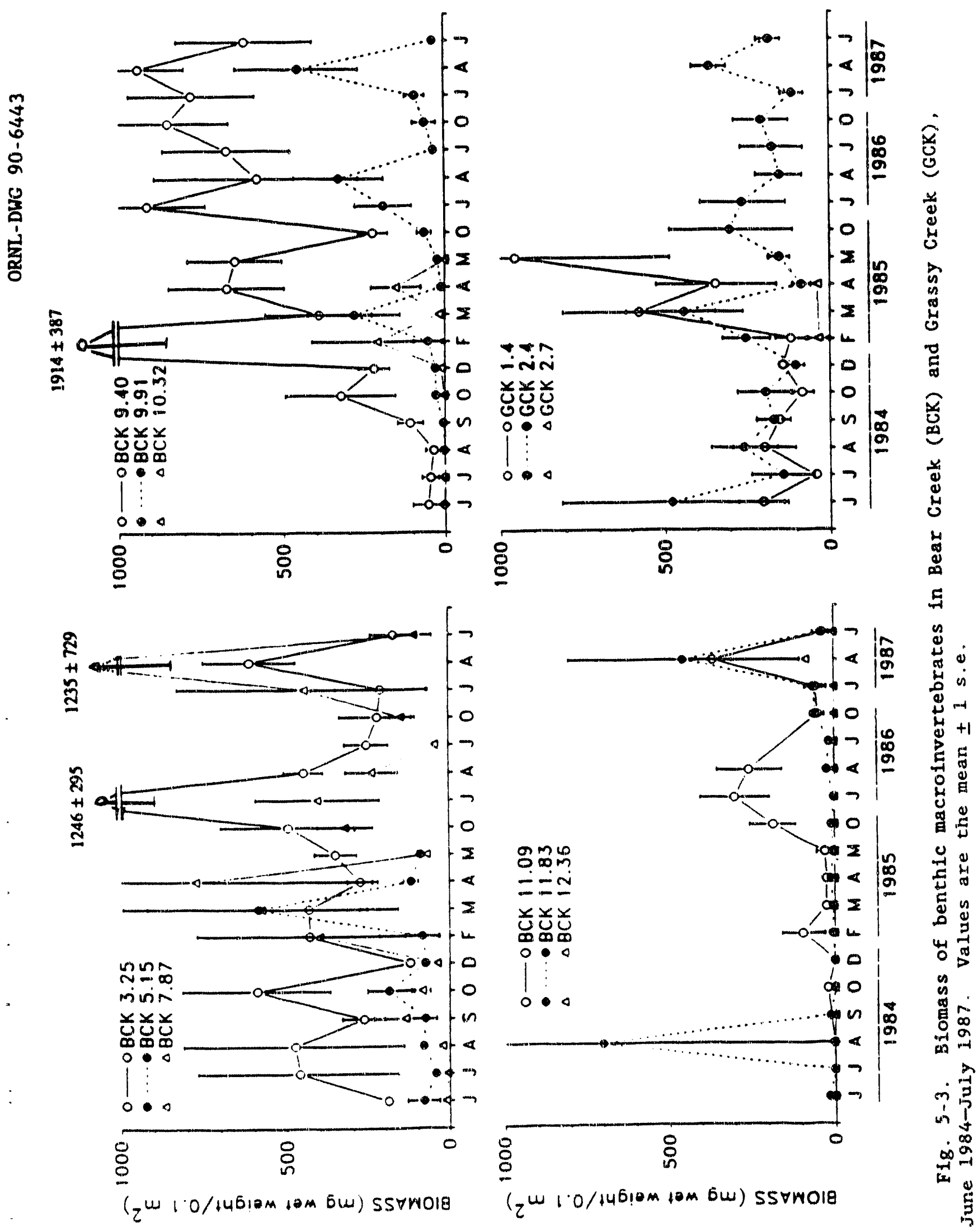


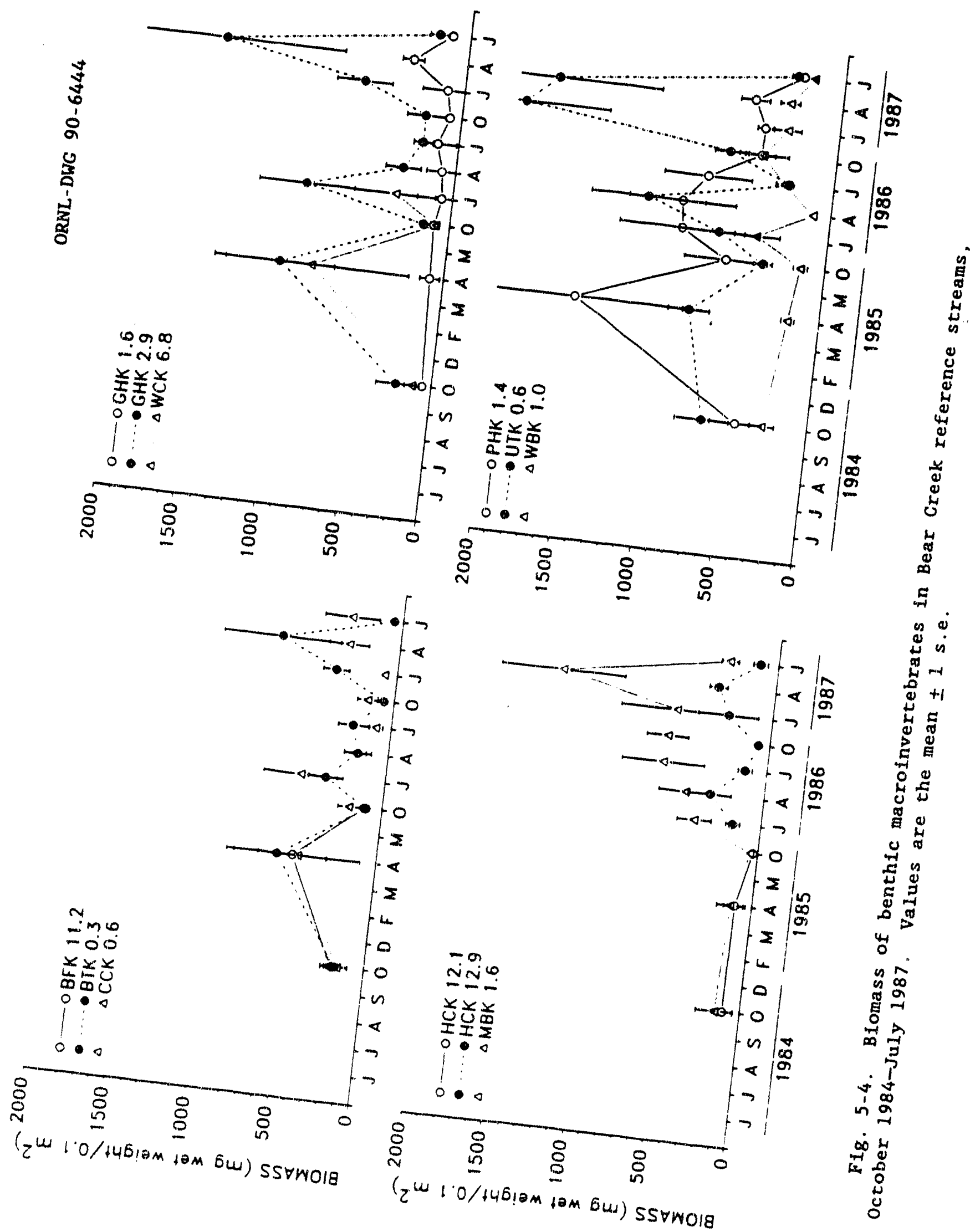


Grassy Creek sites (GCK 1.4 and GCK 2.4), densities in the reference streams consistently approached or exceeded 100 individuals $/ 0.1 \mathrm{~m}^{2}$.

The highest biomass observed in Bear Creek was $1914.0 \mathrm{mg}$ wet wt/0.1 $\mathrm{m}^{2}$ at $\mathrm{BCK}^{\prime} 9.40$ in February 1985 (Fig. 5-3), and the lowest biomass was zero on three sampling dates (see above). Biomass consistently exceeded $100 \mathrm{mg}$ wet $w t / 0.1 \mathrm{~m}^{2}$ at $B C K 3.25$ and $B C K 9.40$, frequently exceeded 100 mg wet wt $/ 0.1 \mathrm{~m}^{2}$ at $B C K ~ 7.87$, and only rarely exceeded this latter value at the sites upstream of SS5.

A biomass of $1946.0 \mathrm{mg}$ wet wt/0.1 $\mathrm{m}^{2}$ at UTK 0.6 in January 1987 was the highest observed for the reference sites, and $30.0 \mathrm{mg}$ wet wt $/ 0.1 \mathrm{~m}^{2}$ at HCK 25.4 in October 1985 was the lowest (Figs. 5-3 and 5-4). Biomass at the reference sites was rarely less than $100 \mathrm{mg}$ wet $w t / 0.1 \mathrm{~m}^{2}$ and most of the time exceeded $200 \mathrm{mg}$ wet wt $/ 0.1 \mathrm{~m}^{2}$.

\subsubsection{Bear Creek vs Reference Sites}

Results of the statistical comparisons of density and biomass between Bear Creek and the reference sites are presented in Appendix $F$, Tables F-9 through F-20. Densities were consistently significantly lower at BCK 11.83 and BCK 12.36 than most or all of the reference sites (Tables F-9 through F-14). Density at BCK 9.91 was significantly lower than most reference sites during the first and third years, whereas density at BCK 11.09 was significantly lower than most reference sites in the third year. BCK 7.87 differed little from the reference sites in all years. Density at BCK 9.40 was never significantly lower than at the reference sites and was sometimes significantly higher. BCK 3.25 differed little from the reference sites during the first two years, sometimes exhibiting a significantly higher density and sometimes exhibiting no difference. During the third year, however, density at BCK 3.25 was significantly lower than the densities at all but two reference sites.

Patterns of significance in biomass (exclusive of Decapoda and Mollusca) were very similar to those of density. Sites located upstream of SS5 generally exhibited significantly lower biomass than most or all of the reference sites, while biomass at sites downstream of the spring was significantly lower than no more than two reference sites in any 
year (Tables F-15 through F-20). Inclusion of the decapods and mollusks had a substantial effect on the patterns of significance for all Bear Creek sites but BCK 3.25, where relatively high densities of mollusks (primarily snails) occurred. Inclusion of all taxa in the analyses resulted in all Bear Creek sites except BCK 3.25 and BCK 9.40 exhibiting biomass values that were significantly lower than values at most or all of the reference sites. Excluding these taxa, biomass at BCK 9.40 was significantly higher than biomass at some reference sites and not significantly different from the others. Inclusion of all taxa, however, revealed that biomass at BCK 9.40 was significantly lower than biomass at two, three, and five reference sites in years 1,2 , and 3 , respectively, and significantly higher than one site in the third year only.

\subsubsection{Dominant Taxa}

Many of the within- and between-site differences in density and biomass of the benthic macroinvertebrate communities in Bear Creek and the reference streams were generally due to a few major taxonomic groups, including the Chironomidae (midges), Coleoptera (beetles), Ephemeroptera (mayflies), Plecoptera (stoneflies), and Trichoptera (caddisflies). Additionally, Diptera (true flies), other than Chironomidae, and Isopoda (aquatic sow bugs) occasionally contributed considerably to the community biomass and/or density at some sites.

Chironomids were consistently one of the most abundant groups in Bear Creek and the reference streans during all three years of the study (Table 5-3). Because of their small size, however, this group contributed little to biomass at any site except those Bear Creek sites above SS5 (Table 5-4). In Bear Creek below SS5 and in the reference streams, chixonomids usually accounted for $<58$ of the biomass, whereas upstream of the spring, they generally accounted for $>108$. With few exceptions, chironomids accounted for more than $65 \%$ of the total community density at these upper Bear Creek sites. The contribution of chironomids to total density was considerably less at the sites downstream of SS5. At BCK 3.25, they accounted for no more than 108 of the total community density, while their contributions to total density 
Table 5-3. Relative density (X of ween) of dowinent benthic macroimertebrate taxa in Bear Creek and reference streases, June 1906-July 1937

\begin{tabular}{|c|c|c|c|c|c|c|c|}
\hline \multirow[b]{2}{*}{ site/year ${ }^{a, b}$} & \multicolumn{7}{|c|}{ Relative density $(x)$} \\
\hline & Chironomidae & Coleoptera & Diptera $^{\mathrm{C}}$ & Ephemeroptera & I sopoda & Plecoptera & Trichoptera \\
\hline \multicolumn{8}{|l|}{ BCK 3.25} \\
\hline Year 1 & 9.3 & 21.6 & 0.7 & 7.1 & 7.6 & 3.6 & 38.7 \\
\hline Year 2 & 8.4 & 24.0 & 4.3 & 10.4 & 7.9 & 6.9 & 28.4 \\
\hline Year 3 & 9.8 & 17.0 & 1.8 & 23.4 & 7.2 & 12.4 & 11.1 \\
\hline \multicolumn{8}{|l|}{ BCK 5.15} \\
\hline Year 1 & 26.7 & 15.5 & 1.0 & 1.4 & 10.8 & 15.4 & 23.9 \\
\hline \multicolumn{8}{|l|}{ BCK 7.87} \\
\hline Year 1 & 42.8 & 11.7 & 5.5 & 0.3 & 3.4 & 23.1 & 10.4 \\
\hline Year 2 & 37.3 & 5.7 & 2.1 & 0.2 & 18.1 & 22.7 & 11.3 \\
\hline Year 3 & 42.5 & 3.4 & 4.4 & 0.8 & 29.4 & 11.6 & 4.4 \\
\hline \multicolumn{8}{|l|}{ BCK 9.40} \\
\hline Year 1 & 28.6 & 2.1 & 1.3 & 0.2 & 54.1 & 7.2 & 4.6 \\
\hline Year 2 & 22.8 & 12.9 & 0.7 & 0.2 & 50.0 & 4.6 & 7.6 \\
\hline Year 3 & 26.1 & 10.7 & 1.0 & 0.2 & 46.4 & 4.3 & 8.4 \\
\hline \multicolumn{8}{|l|}{ BCK 9.91} \\
\hline Year 1 & 76.9 & 0.5 & 3.1 & 0.0 & 9.2 & 1.5 & 2.1 \\
\hline Year 2 & 76.3 & 0.7 & 4.0 & 0.05 & 1.2 & 90.4 & 6.4 \\
\hline Year 3 & 85.8 & 0.2 & 4.6 & 0.0 & 1.8 & 5.2 & 1.5 \\
\hline \multicolumn{8}{|l|}{ BCK 10.32} \\
\hline Year 1 & 75.4 & 0.0 & 3.3 & 0.0 & 0.0 & 13.0 & 1.3 \\
\hline \multicolumn{8}{|l|}{ BCK 11.09} \\
\hline Year 1 & 83.3 & 2.2 & 4.1 & 0.7 & 0.0 & 4.3 & 2.9 \\
\hline Year 2 & 75.9 & 3.4 & 4.8 & 0.0 & 0.1 & 2.6 & 11.0 \\
\hline Year 3 & 73.6 & 15.2 & 4.4 & 0.04 & 0.2 & 4.2 & 0.9 \\
\hline \multicolumn{8}{|l|}{ BCK 11.83} \\
\hline Year 1 & 94.2 & 2.7 & 1.9 & 0.0 & 0.0 & 0.5 & 0.3 \\
\hline Year 2 & 68.8 & 18.3 & 8.2 & 0.0 & 0.0 & 0.3 & 2.0 \\
\hline Year 3 & 38.4 & 39.3 & 9.9 & 0.0 & 0.1 & 2.8 & 5.8 \\
\hline \multicolumn{8}{|l|}{ BCK 12.36} \\
\hline Year 1 & 83.6 & 0.0 & 7.5 & 1.5 & 0.0 & 4.5 & 1.5 \\
\hline Year 2 & 69.0 & 0.0 & 13.8 & 0.0 & 0.0 & 3.4 & 0.0 \\
\hline Year 3 & 99.6 & 0.1 & 0.1 & 0.0 & 0.0 & 0.0 & 0.04 \\
\hline \multicolumn{8}{|l|}{ BFK 19.2} \\
\hline Year 1 & 15.8 & 11.0 & 2.7 & 44.0 & 2.2 & 9.2 & 6.3 \\
\hline
\end{tabular}


rable 5-3 (continued)

\begin{tabular}{|c|c|c|c|c|c|c|c|}
\hline \multirow[b]{2}{*}{ site/year ${ }^{a, b}$} & \multicolumn{7}{|c|}{ Relative density $(x)$} \\
\hline & Chironomidae & Coleoptera & Diptera ${ }^{C}$ & Ephemeroptera & I sopoda & Plecoptera & Trichoptera \\
\hline \multicolumn{8}{|l|}{ BTK 0.3} \\
\hline Year 1 & 41.4 & 5.9 & 11.0 & 22.7 & 0.0 & 8.8 & 2.6 \\
\hline Year 2 & 65.3 & 2.9 & 4.1 & 9.6 & 0.0 & 5.0 & 5.4 \\
\hline Year 3 & 68.3 & 2.6 & 3.9 & 11.5 & 0.0 & 5.1 & 2.5 \\
\hline \multicolumn{8}{|l|}{ CCK 0.6} \\
\hline Year 1 & 7.0 & 11.9 & 2.1 & 15.8 & 23.0 & 5.7 & 8.5 \\
\hline Year 2 & 14.4 & 6.7 & 0.9 & 20.6 & 19.0 & 13.9 & 6.3 \\
\hline Year 3 & 20.0 & 7.5 & 1.9 & 9.6 & 29.6 & 11.6 & 3.9 \\
\hline \multicolumn{8}{|l|}{$\operatorname{GCK} 1.4$} \\
\hline Year 1 & 10.7 & 11.2 & 1.3 & 6.3 & 4.2 & 30.4 & 15.8 \\
\hline \multicolumn{8}{|l|}{$\operatorname{cock} 2.4$} \\
\hline Year 1 & 9.3 & 22.4 & 5.4 & 6.6 & 0.2 & 4.8 & 7.5 \\
\hline Year 2 & 25.3 & 12.0 & 4.7 & 3.5 & 0.1 & 2.7 & 6.1 \\
\hline Year 3 & 34.2 & 10.8 & 9.4 & 11.7 & 0.0 & 5.7 & 4.7 \\
\hline \multicolumn{8}{|l|}{ GHK 1.6} \\
\hline Year 1 & 10.2 & 7.6 & 2.3 & 55.7 & 0.1 & 91.2 & 3.1 \\
\hline Year 2 & 18.1 & 6.8 & 0.7 & 23.9 & 0.1 & 26.1 & 4.5 \\
\hline Year 3 & 27.8 & 13.2 & 12.1 & 12.1 & 0.03 & 28.4 & 4.5 \\
\hline \multicolumn{8}{|l|}{ GHK 2.9} \\
\hline Year 1 & 12.3 & 24.2 & 4.0 & 14.7 & 1.8 & 6.8 & 10.0 \\
\hline Year 2 & 35.0 & 17.0 & 3.9 & 2.9 & 0.4 & 5.4 & 9.2 \\
\hline Year 3 & 30.5 & 8.9 & 3.5 & 8.4 & 0.3 & 24.8 & 6.1 \\
\hline \multicolumn{8}{|l|}{ HCK 20.6} \\
\hline Year 2 & 45.8 & 4.9 & 2.5 & 24.6 & 1.8 & 1.7 & 4.4 \\
\hline Year 3 & 69.9 & 5.5 & 1.4 & 13.7 & 1.6 & 1.7 & 4.2 \\
\hline \multicolumn{8}{|l|}{ HCX 25.4} \\
\hline Year 1 & 41.7 & 1.4 & 1.5 & 18.9 & 0.0 & 21.2 & 8.5 \\
\hline \multicolumn{8}{|l|}{ MBK 1.6} \\
\hline Year 1 & 33.8 & 6.0 & 4.7 & 29.1 & 0.1 & 1.9 & 4.3 \\
\hline Year 2 & 29.8 & 13.5 & 1.6 & 10.4 & 0.4 & 6.7 & 12.4 \\
\hline Year 3 & 45.6 & 13.3 & 2.7 & 15.2 & 0.4 & 3.2 & 6.6 \\
\hline \multicolumn{8}{|l|}{ PHK 1.4} \\
\hline Year 1 & 8.5 & 5.5 & 2.4 & 7.7 & 42.6 & 14.7 & 14.7 \\
\hline Year 2 & 11.7 & 7.7 & 3.9 & 7.4 & 24.6 & 8.3 & 30.1 \\
\hline Year 3 & 28.5 & 4.0 & 3.5 & 7.9 & 41.3 & 4.6 & 3.4 \\
\hline
\end{tabular}


Table 5-3 (continued)

\begin{tabular}{|c|c|c|c|c|c|c|c|}
\hline \multirow[b]{2}{*}{ site/year ${ }^{a, b}$} & \multicolumn{7}{|c|}{ Relative densiry $(x)$} \\
\hline & Chironomidae & Coleoptera & Diptera ${ }^{c}$ & Ephemeroptera & Isopoda & Plecoptera & Trichoptera \\
\hline \multicolumn{8}{|l|}{ UTK 0.6} \\
\hline Year 1 & 15.5 & 3.4 & 1.6 & 34.8 & 31.1 & 2.4 & 7.3 \\
\hline Year 2 & 25.7 & 6.2 & 2.8 & 33.2 & 8.2 & 4.5 & 12.8 \\
\hline Year 3 & 34.1 & 5.1 & 2.9 & 21.6 & 17.2 & 4.0 & 8.7 \\
\hline \multicolumn{8}{|l|}{ WBK 1.0} \\
\hline Year 1 & 10.0 & 28.3 & 1.2 & 12.4 & 0.2 & 2.0 & 2.5 \\
\hline Year 2 & 8.7 & 12.3 & 1.2 & 13.1 & 0.1 & 18.3 & 5.6 \\
\hline Year 3 & 32.6 & 17.0 & 1.6 & 13.4 & 0.02 & 13.7 & 2.6 \\
\hline \multicolumn{8}{|l|}{ WCK 6.8} \\
\hline Year 1 & 18.7 & 11.2 & 2.6 & 14.1 & 0.0 & 6.3 & 7.0 \\
\hline
\end{tabular}

${ }^{a}$ Year 1 = June 1984-May 1985; year 2 = October 1985-July 1986; and year 3 = October 1986-July 1987.

Bear 1 includes data from 10 months for all Bear Creek (BCK) and Grassy Creek (GCK) sites and October 1984 and April 1985 for all other sites.

EExcludes Chironomidae. 
Table 5-4. Relative bicmass ( $x$ of an) of dominant benthic macroimertebrate taxa in Bear Creek and reference streess, June 19\%-July 1987

\begin{tabular}{|c|c|c|c|c|c|c|c|}
\hline \multirow[b]{2}{*}{ site/year ${ }^{a, b}$} & \multicolumn{7}{|c|}{ Relative density $(x)$} \\
\hline & Chironomidae & Coleoptera & Diptera $^{c}$ & Ephemeroptera & I sopoda & Plecoptera & Trichoptera \\
\hline \multicolumn{8}{|l|}{ BCK 3.25} \\
\hline Year 1 & 0.9 & 31.4 & 4.5 & 4.6 & 7.8 & 4.4 & 37.8 \\
\hline Year 2 & 0.9 & 22.2 & 17.8 & 17.8 & 10.7 & 5.3 & 29.5 \\
\hline Year 3 & 1.4 & 22.8 & 23.7 & 23.7 & 7.2 & 6.4 & 19.3 \\
\hline \multicolumn{8}{|l|}{ BCK 5.15} \\
\hline Year 1 & 3.8 & 6.9 & 0.9 & 0.9 & 15.7 & 14.6 & 23.3 \\
\hline \multicolumn{8}{|l|}{ BCK 7.87} \\
\hline Year 1 & 3.3 & 3.4 & 67.5 & 0.1 & 4.5 & 10.8 & 8.0 \\
\hline Year 2 & 4.4 & 2.3 & 22.8 & 0.1 & 27.1 & 6.3 & 14.8 \\
\hline Year 3 & 3.7 & 0.5 & 56.3 & 0.1 & 25.0 & 2.9 & 4.2 \\
\hline \multicolumn{8}{|l|}{ BCK 9.40} \\
\hline Year 1 & 2.2 & 0.6 & 32.1 & 0.05 & 50.6 & 4.7 & 9.1 \\
\hline Year 2 & 2.3 & 12.9 & 18.1 & 0.1 & 58.7 & 2.9 & 11.2 \\
\hline Year 3 & 3.7 & 4.2 & 2.8 & 0.4 & 64.4 & 3.8 & 14.1 \\
\hline \multicolumn{8}{|l|}{ BCK 9.91} \\
\hline Year 1 & 8.5 & 0.4 & 34.6 & 0.0 & 21.7 & 1.0 & 1.7 \\
\hline Year 2 & 13.8 & 0.4 & 37.6 & 0.02 & 4.9 & 16.1 & 24.6 \\
\hline Year 3 & 44.8 & 0.3 & 5.0 & 0.0 & 10.9 & 24.3 & 11.0 \\
\hline \multicolumn{8}{|l|}{ BCK 10.32} \\
\hline Year 1 & 5.4 & 0.0 & 44.7 & 0.0 & 0.0 & 15.2 & 2.6 \\
\hline \multicolumn{8}{|l|}{ BCK 11.09} \\
\hline Year 1 & 18.0 & 1.7 & 6.4 & 0.3 & 0.0 & 7.7 & 8.7 \\
\hline Year 2 & 17.4 & 1.5 & 31.0 & 0.0 & 0.2 & 6.2 & 40.2 \\
\hline Year 3 & 32.3 & 11.4 & 5.1 & 0.1 & 0.3 & 21.6 & 6.1 \\
\hline \multicolumn{8}{|l|}{ BCK 11.83} \\
\hline Year 1 & 6.2 & 0.9 & 91.7 & 0.0 & 0.0 & 1.0 & 0.04 \\
\hline Year 2 & 40.3 & 35.3 & 7.7 & 0.0 & 0.0 & 1.2 & 10.5 \\
\hline Year 3 & 4.6 & 9.2 & 28.7 & 0.0 & 0.02 & 5.8 & 9.0 \\
\hline \multicolumn{8}{|l|}{ BCK 12.36} \\
\hline Year 1 & 53.2 & 0.0 & 10.0 & 5.8 & 0.0 & 20.7 & 10.4 \\
\hline Year 2 & 38.7 & 0.0 & 22.2 & 0.0 & 0.0 & 8.8 & 0.0 \\
\hline Year 3 & 98.5 & 0.7 & 0.03 & 0.0 & 0.0 & 0.0 & 0.4 \\
\hline \multicolumn{8}{|l|}{ BFK 11.2} \\
\hline Year 1 & 1.2 & 6.7 & 28.3 & 34.9 & 1.0 & 7.0 & 9.1 \\
\hline
\end{tabular}


Table 5-4 (continued)

\begin{tabular}{|c|c|c|c|c|c|c|c|}
\hline \multirow[b]{2}{*}{ site/year ${ }^{a, b}$} & \multicolumn{7}{|c|}{ Relative density $(\%)$} \\
\hline & Chironomidae & Coleoptera & Diptera ${ }^{c}$ & Ephemeroptera & I sopoda & Plecoptera & Trichoptera \\
\hline \multicolumn{8}{|l|}{ BTK 0.3} \\
\hline Year 1 & 4.8 & 4.3 & 30.3 & 12.0 & 0.0 & 11.8 & 14.3 \\
\hline Year 2 & 8.3 & 3.8 & 13.8 & 8.2 & 0.0 & 6.7 & 33.3 \\
\hline Year 3 & 7.9 & 2.9 & 14.9 & 12.3 & 0.0 & 5.6 & 38.3 \\
\hline \multicolumn{8}{|l|}{ CCK 0.6} \\
\hline Year 1 & 0.6 & 2.5 & 39.7 & 29.2 & 8.8 & 1.9 & 10.9 \\
\hline Year 2 & 3.6 & 4.1 & 28.9 & 17.7 & 15.3 & 4.7 & 12.7 \\
\hline Year 3 & 4.0 & 4.5 & 29.1 & 13.5 & 17.7 & 4.8 & 13.7 \\
\hline \multicolumn{8}{|l|}{ GCK 1.4} \\
\hline Year 1 & 0.6 & 4.3 & 47.3 & 2.9 & 2.9 & 8.4 & 15.8 \\
\hline \multicolumn{8}{|l|}{ GCK 2.4} \\
\hline Year 1 & 0.7 & 19.4 & 19.2 & 2.4 & 0.03 & 4.6 & 35.6 \\
\hline Year 2 & 2.7 & 10.4 & 17.2 & 1.9 & 0.05 & 4.8 & 19.7 \\
\hline Year 3 & 4.4 & 13.4 & 10.7 & 9.4 & 0.0 & 2.4 & 29.0 \\
\hline \multicolumn{8}{|l|}{ GHK 1.6} \\
\hline Year 1 & 0.3 & 6.6 & 0.7 & 60.9 & 0.01 & 6.8 & 7.3 \\
\hline Year 2 & 1.0 & 5.7 & 42.9 & 16.5 & 0.1 & 7.8 & 6.9 \\
\hline Year 3 & 4.6 & 14.3 & 33.3 & 9.6 & 0.004 & 6.8 & 7.2 \\
\hline \multicolumn{8}{|l|}{ GHK 2.9} \\
\hline Year 1 & 0.4 & 14.4 & 38.5 & 7.8 & 1.4 & 10.0 & 16.0 \\
\hline Year 2 & 2.3 & 18.7 & 40.3 & 0.6 & 0.7 & 8.1 & 18.0 \\
\hline Year 3 & 2.0 & 11.3 & 61.5 & 2.7 & 0.1 & 4.7 & 12.2 \\
\hline \multicolumn{8}{|l|}{ HCK 20.6} \\
\hline Year 2 & 13.3 & 3.9 & 3.8 & 27.7 & 0.6 & 0.8 & 21.4 \\
\hline Year 3 & 10.8 & 5.5 & 27.0 & 18.3 & 1.3 & 0.6 & 30.6 \\
\hline \multicolumn{8}{|l|}{ HCK 25.4} \\
\hline Year 1 & 5.0 & 1.7 & 16.7 & 20.1 & 0.0 & 7.8 & 10.6 \\
\hline \multicolumn{8}{|l|}{ MBK 1.6} \\
\hline Year 1 & 2.5 & 10.0 & 8.2 & 18.9 & 0.5 & 1.1 & 23.0 \\
\hline Year 2 & 1.7 & 15.6 & 27.0 & 4.2 & 0.3 & 12.6 & 11.5 \\
\hline Year 3 & 3.9 & 11.5 & 43.1 & 4.2 & 0.1 & 6.3 & 14.1 \\
\hline \multicolumn{8}{|l|}{ PHK 1.4} \\
\hline Year 1 & 0.3 & 2.3 & 24.3 & 2.8 & 23.4 & 19.7 & 23.6 \\
\hline Year 2 & 0.5 & 3.5 & 19.5 & 6.4 & 13.4 & 7.8 & 21.1 \\
\hline Year 3 & 2.1 & 2.3 & 13.6 & 5.4 & 38.0 & 1.5 & 10.0 \\
\hline
\end{tabular}


Table 5-4 (cont inved)

\begin{tabular}{|c|c|c|c|c|c|c|c|}
\hline \multirow[b]{2}{*}{ site/year $a, b$} & \multicolumn{7}{|c|}{ Relative density $(x)$} \\
\hline & Chironomidae & Coleoptera & Diptera ${ }^{c}$ & Ephemeroptera & Isopoda & Plecoptera & Trichoptera \\
\hline \multicolumn{8}{|l|}{ UTK 0.6} \\
\hline Year 1 & 0.9 & 2.1 & 25.5 & 36.0 & 13.4 & 3.6 & 13.4 \\
\hline Year 2 & 2.0 & 3.1 & 17.9 & 33.8 & 5.6 & 1.9 & 23.2 \\
\hline Year 3 & 2.6 & 2.2 & 27.5 & 29.1 & 10.4 & 2.8 & 16.5 \\
\hline \multicolumn{8}{|l|}{ WBK 1.0} \\
\hline Year 1 & 0.5 & 52.2 & 0.3 & 14.2 & 0.1 & 1.4 & 3.0 \\
\hline Year 2 & 1.1 & 19.1 & 1.0 & 22.7 & 0.02 & 6.3 & 14.3 \\
\hline Year 3 & 4.5 & 16.5 & 0.9 & 35.9 & 0.01 & 3.2 & 5.9 \\
\hline \multicolumn{8}{|l|}{ WCK 6.8} \\
\hline Year 1 & 2.9 & 6.9 & 12.5 & 5.6 & 0.0 & 5.0 & 2.4 \\
\hline
\end{tabular}

ayear $1=$ June 1984-May 1985; year 2 = October 1985-July 1986; and year $3=$ October 1986-July 1987.

byear 1 includes data from 10 months for all Bear Creek (BCK) and Grassy Creek (GCK) sites and October 1984 and April 1985 for all other sites.

"Excludes Chironomidae. 
at $B C K 5.15, B C K ~ 7.87$, and $B C K 9.40$ ranged from 23 to 438 . Chironomids comprised from 7 to 468 of the total density at all reference sites except BTK 0.3 and HSK 20.6 where they accounted for 41 to $68 \%$ of the total community density.

The relative abundance of dipterans (true flies), exclusive of chironomids, at all Bear Creek and reference sites ranged from 0.1 to 148 but rarely exceeded 58 (Tables $5-3$ and $5-4$ ). Their relative biomass on the other hand, varied considerably from site to site and from year to year, ranging from $<0.1$ to 928 in Bear Creek and from 0.3 to 628 in the reference streams. As a result of their size, the relative biomass of this group was generally greatest at those sites where the relative density of the chironomids was greatest.

With the exception of $B C K$ 11.83, the relative density and biomass of Coleoptera (beetles) generally increased with increasing distance from the Y-12 Plant (Tables $5-3$ and 5-4). The relative density of beetles was generally greater than $5 \%$ in Bear Creek below SS5, at $B C K 11.83$, and in the reference streams but rarely exceeded 58 at the remaining Bear Creek sites. Relative biomass also increased with increasing distance from the Y-I2 Plant. At those sites downstream of SS5, the relative biomass of beetles was similar to that of the reference sites.

Compared to the reference sites, the relative abundance and biomass of Ephemeroptera (mayflies) in Bear Creek at all sites upstream of BCK 3.25 were extremely low (Tables $5-3$ and 5-4). The relative density and biomass of this group exceeded 18 at these upstream sites nly once, and in many cases was 08 . Relative density and biomass of mayflies at BCK 3.25 were as high as or higher than most of the reference sites.

The relative density and biomass of Isopoda (aquatic sow bugs) varied considerably between both the Bear Creek sites and the reference sites (Tables 5-3 and 5-4). Except at BCK 9.91, where they contributed up to 22 of the total comunity biomass, isopods contributed little to either density or biomass at those Bear Creek sites above SS5. The high relative biomass of isopods at $B C K 9.91$ was primarily due to their large biomass relative to the more numerically dominant chironomids. Isopods were collected at all reference sites except BTK 0.3, HCK 25.4, and 
WCK 6.8 , but only contributed substantially to total community density and blomass at CCK 0.6 , PHK 1.4 , and UTK 0.6 .

The relative density of plecoptera (stoneflies) was highest in Bear Creek below SS5, although relative densities above the spring were comparable, in many cases, to those of some of the reference sites (Table 5-3). The relative biomass of stoneflies in Bear Creek above SS5 was generally similar to the biomass below the spring and at the reference sites (Table 5-4); however, this was primarily because of their large size relative to the more abundant chironomids.

Relative densities of Trichoptera (caddisflies) exhibited a general decline with increasing proximity to the Y-12 Plant, and above SS5 relative densities were generally lower than at the reference sites (Table 5-3). Relative biomass of the caddisflies displayed considerable site-to-site and year-to-year variability in both Bear Creek and the reference streams (Table 5-4). Except for the first year, relative density and biomass were lowest at BCK 12.36; both parameters were highest at $B C K 3.25$ in all three years. Although relative density and biomass differed at some upper Bear Creek sites, the two parameters were comparable to one another at sites below SS5 and at the reference sites.

\subsubsection{Community Structure}

\subsubsection{Richness}

Taxonomic richness generally increased with increasing distance from the Y-12 Plant during all chree years (Table 5-5). The highest number of taxa were collected at BCK 3.25 in years 1 and 2. (61 and 69 taxa, respectively), and at BCK 9.40 in year 3 ( 78 taxa). The fewest taxa were collected in all three years at BCK 12.36, ranging from 6 to 22 in years 2 and 1 , respectively.

Total richness of benthic invertebrates at the reference sites during the first year ranged from 45 taxa in Clear Creek near Norris (CCK 0.6) to 74 taxa in Grassy Creek at GCK 1.4 (Table 5-5). With the exception of the Grassy Creek sites, howevex, all reference sites were sampled in only two months during the first year. Thus, during the first year, only the total number of taxa collected in the Grassy Creek sites, which exceeded the total taxa for all Bear Creek sites, can be 
Table 5-5. Total richness (total number of taxa collected in quantitative samples), mean richness (number of taxa per sample), and diversity ( $\left.H^{\prime}\right)$ of benthic macroinvertebrates in Bear Creek and reference sites, June 1984-July 1987. Values in parentheses are \pm 1 . SE.

$\mathrm{N}=$ No. of samples

\begin{tabular}{|c|c|c|c|c|c|}
\hline Site & $\begin{array}{l}\text { Sampling } \\
\text { period }^{a}\end{array}$ & $\mathrm{~N}$ & $\begin{array}{l}\text { Total } \\
\text { richness }\end{array}$ & $\begin{array}{l}\text { Mean } \\
\text { richness }\end{array}$ & Diversity \\
\hline \multirow[t]{4}{*}{ BCK 3.25} & 1 & 30 & 61 & $\begin{array}{l}13.3 \\
(1.1)\end{array}$ & $\begin{array}{r}2.86 \\
(0.1)\end{array}$ \\
\hline & $1^{b}$ & 6 & - & $\begin{array}{l}15.0 \\
(0.7)\end{array}$ & $\begin{array}{c}2.96 \\
(0.18)\end{array}$ \\
\hline & 2 & 20 & 69 & $\begin{array}{l}21.6 \\
(1.2)\end{array}$ & $\begin{array}{c}3.29 \\
(0.16)\end{array}$ \\
\hline & 3 & 20 & 66 & $\begin{array}{l}18.8 \\
(2.9)\end{array}$ & $\begin{array}{c}3.31 \\
(0.14)\end{array}$ \\
\hline \multirow[t]{2}{*}{ BCK 5.15} & 1 & 30 & 50 & $\begin{array}{c}9.8 \\
(1.2)\end{array}$ & $\begin{array}{c}2.54 \\
(0.13)\end{array}$ \\
\hline & $1^{b}$ & 6 & - & $\begin{array}{c}9.8 \\
(0.5)\end{array}$ & $\begin{array}{c}2.42 \\
(0.01)\end{array}$ \\
\hline \multirow[t]{4}{*}{ BCK 7.87} & 1 & 30 & 49 & $\begin{array}{c}9.0 \\
(1.2)\end{array}$ & $\begin{array}{c}2.31 \\
(0.13)\end{array}$ \\
\hline & $1^{b}$ & 6 & - & $\begin{array}{l}11.2 \\
(1.5)\end{array}$ & $\begin{array}{c}2.37 \\
(0.16)\end{array}$ \\
\hline & 2 & 20 & 55 & $\begin{array}{l}13.2 \\
(1.5)\end{array}$ & $\begin{array}{c}2.86 \\
(0.18)\end{array}$ \\
\hline & 3 & 19 & 59 & $\begin{array}{l}16.1 \\
(1.3)\end{array}$ & $\begin{array}{c}2.87 \\
(0.21)\end{array}$ \\
\hline \multirow[t]{4}{*}{ BCK 9.40} & 1 & 30 & 54 & $\begin{array}{c}9.5 \\
(1.4)\end{array}$ & $\begin{array}{c}1.92 \\
(0.25)\end{array}$ \\
\hline & $1^{b}$ & 6 & - & $\begin{array}{l}11.3 \\
(0.7)\end{array}$ & $\begin{array}{c}2.24 \\
(0.27)\end{array}$ \\
\hline & 2 & 19 & 55 & $\begin{array}{l}15.2 \\
(1.5)\end{array}$ & $\begin{array}{c}2.37 \\
(0.33)\end{array}$ \\
\hline & 3 & 20 & 78 & $\begin{array}{l}22.5 \\
(1.0)\end{array}$ & $\begin{array}{c}2.48 \\
(0.21)\end{array}$ \\
\hline \multirow[t]{4}{*}{ BCK 9.91} & 1 & 30 & 41 & $\begin{array}{c}4.2 \\
(0.5)\end{array}$ & $\begin{array}{c}1.45 \\
(0.20)\end{array}$ \\
\hline & $1^{b}$ & 6 & - & $\begin{array}{c}4.8 \\
(0.2)\end{array}$ & $\begin{array}{c}1.74 \\
(0.02)\end{array}$ \\
\hline & 2 & 19 & 45 & $\begin{array}{c}9.0 \\
(2.0)\end{array}$ & $\begin{array}{c}1.81 \\
(0.41)\end{array}$ \\
\hline & 3 & 20 & 45 & $\begin{array}{c}9.6 \\
(0.7)\end{array}$ & $\begin{array}{c}1.83 \\
(0.31)\end{array}$ \\
\hline
\end{tabular}


Table 5-5 (continued)

\begin{tabular}{|c|c|c|c|c|c|}
\hline Site & $\begin{array}{l}\text { Sampling } \\
\text { period" }\end{array}$ & $\mathrm{N}$ & $\begin{array}{l}\text { Total } \\
\text { richness }\end{array}$ & $\begin{array}{c}\text { Mean } \\
\text { richness }\end{array}$ & Diversity \\
\hline \multirow[t]{2}{*}{ BCK 10.32} & 1 & 21 & 30 & $\begin{array}{c}4.3 \\
(0.9)\end{array}$ & $\begin{array}{c}1.47 \\
(0.30)\end{array}$ \\
\hline & $1^{b}$ & 6 & - & $\begin{array}{c}6.3 \\
(0.3)\end{array}$ & $\begin{array}{c}2.20 \\
(0.06)\end{array}$ \\
\hline \multirow[t]{4}{*}{ BCK 11.09} & 1 & 27 & 36 & $\begin{array}{c}3.8 \\
(0.6)\end{array}$ & $\begin{array}{c}1.30 \\
(0.19)\end{array}$ \\
\hline & $1^{b}$ & 6 & - & $\begin{array}{c}6.3 \\
(0.7)\end{array}$ & $\begin{array}{c}1.95 \\
(0.27)\end{array}$ \\
\hline & 2 & 15 & 39 & $\begin{array}{l}10.5 \\
(1.6)\end{array}$ & $\begin{array}{c}2.12 \\
(0.03)\end{array}$ \\
\hline & 3 & 20 & 39 & $\begin{array}{c}9.1 \\
(1.8)\end{array}$ & $\begin{array}{c}1.71 \\
(0.21)\end{array}$ \\
\hline \multirow[t]{4}{*}{ BCK 11.83} & 1 & 30 & 24 & $\begin{array}{c}2.2 \\
(0.4)\end{array}$ & $\begin{array}{c}0.65 \\
(0.14)\end{array}$ \\
\hline & $1^{b}$ & 6 & - & $\begin{array}{c}3.2 \\
(0.5)\end{array}$ & $\begin{array}{c}1.00 \\
(0.27)\end{array}$ \\
\hline & 2 & 20 & 23 & $\begin{array}{c}4.2 \\
(0.6)\end{array}$ & $\begin{array}{c}1.22 \\
(0.21)\end{array}$ \\
\hline & 3 & 20 & 41 & $\begin{array}{c}7.7 \\
(1.6)\end{array}$ & $\begin{array}{c}1.79 \\
(0.22)\end{array}$ \\
\hline \multirow[t]{4}{*}{ BCK 12.36} & 1 & 30 & 22 & $\begin{array}{c}1.2 \\
(0.2)\end{array}$ & $\begin{array}{c}0.42 \\
(0.10)\end{array}$ \\
\hline & $1^{\mathrm{b}}$ & 6 & $"$ & $\begin{array}{c}1.2 \\
(0.5)\end{array}$ & $\begin{array}{l}0.45 \\
(.15)\end{array}$ \\
\hline & 2 & 20 & 6 & $\begin{array}{c}0.8 \\
(0.1)\end{array}$ & $\begin{array}{c}0.17 \\
(0.06)\end{array}$ \\
\hline & 3 & 20 & 12 & $\begin{array}{c}1.6 \\
(0.8)\end{array}$ & $\begin{array}{c}0.58 \\
(0.28)\end{array}$ \\
\hline BFK 11.2 & 1 & 8 & 59 & $\begin{array}{l}22.3 \\
(5.1)\end{array}$ & $\begin{array}{c}3.66 \\
(0.31)\end{array}$ \\
\hline \multirow[t]{3}{*}{ BTK 0.3} & 1 & 8 & 62 & $\begin{array}{l}19.9 \\
(2.5)\end{array}$ & $\begin{array}{c}3.55 \\
(0.09)\end{array}$ \\
\hline & 2 & 19 & 86 & $\begin{array}{l}24.5 \\
(2.3)\end{array}$ & $\begin{array}{c}3.76 \\
(0.07)\end{array}$ \\
\hline & 3 & 20 & 103 & $\begin{array}{l}28.7 \\
(3.7)\end{array}$ & $\begin{array}{c}3.99 \\
(0.21)\end{array}$ \\
\hline
\end{tabular}


Table 5-5 (continued)

\begin{tabular}{|c|c|c|c|c|c|}
\hline Site & $\begin{array}{l}\text { Sampling } \\
\text { period }^{\mathrm{a}}\end{array}$ & $N$ & $\begin{array}{c}\text { Total } \\
\text { richness }\end{array}$ & $\begin{array}{l}\text { Mean } \\
\text { richness }\end{array}$ & Diversity \\
\hline \multirow[t]{3}{*}{ CCK 0.6} & 1 & 8 & 45 & $\begin{array}{l}13.6 \\
(0.6)\end{array}$ & $\begin{array}{c}2.75 \\
(0.10)\end{array}$ \\
\hline & 2 & 19 & 81 & $\begin{array}{l}20.8 \\
(2.4)\end{array}$ & $\begin{array}{c}3.20 \\
(0.18)\end{array}$ \\
\hline & 3 & 20 & 99 & $\begin{array}{l}26.7 \\
(1.6)\end{array}$ & $\begin{array}{c}3.39 \\
(0.19)\end{array}$ \\
\hline \multirow[t]{2}{*}{ GCK 1.4} & 1 & 30 & 74 & $\begin{array}{l}14.8 \\
(0.9)\end{array}$ & $\begin{array}{c}3.01 \\
(0.16)\end{array}$ \\
\hline & $1^{b}$ & 6 & - & $\begin{array}{l}13.5 \\
(0.2)\end{array}$ & $\begin{array}{l}3.0 \\
(0.01)\end{array}$ \\
\hline \multirow[t]{4}{*}{ GCK 2.4} & 1 & 30 & 66 & $\begin{array}{l}12.6 \\
(1.4)\end{array}$ & $\begin{array}{c}2.78 \\
(0.24)\end{array}$ \\
\hline & $1^{b}$ & 6 & - & $\begin{array}{l}12.0 \\
(0.0)\end{array}$ & $\begin{array}{c}2.86 \\
(0.21)\end{array}$ \\
\hline & 2 & 20 & 84 & $\begin{array}{l}17.7 \\
(2.8)\end{array}$ & $\begin{array}{c}2.98 \\
(0.17)\end{array}$ \\
\hline & 3 & 20 & 90 & $\begin{array}{l}25.4 \\
(3.0)\end{array}$ & $\begin{array}{c}3.61 \\
(0.26)\end{array}$ \\
\hline \multirow[t]{3}{*}{ GHK 1.6} & 1 & 8 & 52. & $\begin{array}{l}17.4 \\
(1.6)\end{array}$ & $\begin{array}{c}3.32 \\
(0.12)\end{array}$ \\
\hline & 2 & 18 & 74 & $\begin{array}{l}20.4 \\
(2.3)\end{array}$ & $\begin{array}{c}3.46 \\
(0.19)\end{array}$ \\
\hline & 3 & 20 & 88 & $\begin{array}{l}24.9 \\
(2.6)\end{array}$ & $\begin{array}{c}3.64 \\
(0.09)\end{array}$ \\
\hline \multirow[t]{3}{*}{ GHK 2.9} & 1 & 8 & 54 & $\begin{array}{l}1.7 .0 \\
(4.0)\end{array}$ & $\begin{array}{c}3.14 \\
(0.22)\end{array}$ \\
\hline & 2 & 20 & 71 & $\begin{array}{l}20.1 \\
(3.1)\end{array}$ & $\begin{array}{c}3.33 \\
(0.16)\end{array}$ \\
\hline & 3 & 20 & 93 & $\begin{array}{l}27.8 \\
(1.1)\end{array}$ & $\begin{array}{c}3.52 \\
(0.17)\end{array}$ \\
\hline \multirow[t]{2}{*}{ HCK 20.6} & 2 & 15 & 71. & $\begin{array}{l}19.8 \\
(1.7)\end{array}$ & $\begin{array}{c}3.35 \\
(0.24)\end{array}$ \\
\hline & 3 & 20 & 92 & $\begin{array}{l}25.4 \\
(1.4)\end{array}$ & $\begin{array}{c}3.56 \\
(0.13)\end{array}$ \\
\hline HCK 25.4 & 1 & 8 & 49 & $\begin{array}{l}12.7 \\
(2.3)\end{array}$ & $\begin{array}{c}2.63 \\
(0.62)\end{array}$ \\
\hline
\end{tabular}


Table 5-5 (continued)

\begin{tabular}{|c|c|c|c|c|c|}
\hline Site & $\begin{array}{l}\text { Sampling } \\
\text { period }^{a}\end{array}$ & $N$ & $\begin{array}{c}\text { Total } \\
\text { richness }\end{array}$ & $\begin{array}{l}\text { Mean } \\
\text { richness }\end{array}$ & Diversity \\
\hline \multirow[t]{3}{*}{ MBK 1.6} & 1 & 8 & 52 & $\begin{array}{l}14.5 \\
(0.1)\end{array}$ & $\begin{array}{c}3.02 \\
(0.08)\end{array}$ \\
\hline & 2 & 19 & 81 & $\begin{array}{l}20.9 \\
(1.6)\end{array}$ & $\begin{array}{c}3.35 \\
(0.22)\end{array}$ \\
\hline & 3 & 20 & 104 & $\begin{array}{l}35.8 \\
(2.6)\end{array}$ & $\begin{array}{c}3.92 \\
(0.21)\end{array}$ \\
\hline \multirow[t]{3}{*}{ PHK 1.4} & 1 & 8 & 58 & $\begin{array}{l}21.2 \\
(0.8)\end{array}$ & $\begin{array}{c}2.89 \\
(0.05)\end{array}$ \\
\hline & 2 & 19 & 81 & $\begin{array}{l}20.7 \\
(1.1)\end{array}$ & $\begin{array}{c}3.34 \\
(0.11)\end{array}$ \\
\hline & 3 & 20 & 100 & $\begin{array}{l}28.8 \\
(0.8)\end{array}$ & $\begin{array}{c}3.18 \\
(0.37)\end{array}$ \\
\hline \multirow[t]{3}{*}{ UTK 0.6} & 1 & 8 & 64 & $\begin{array}{l}24.3 \\
(2.7)\end{array}$ & $\begin{array}{c}3.33 \\
(0.09)\end{array}$ \\
\hline & 2 & 19 & 88 & $\begin{array}{l}28.0 \\
(2.3)\end{array}$ & $\begin{array}{c}3.84 \\
(0.10)\end{array}$ \\
\hline & 3 & 19 & 103 & $\begin{array}{l}36.3 \\
(1.3)\end{array}$ & $\begin{array}{c}4.05 \\
(0.13)\end{array}$ \\
\hline \multirow[t]{3}{*}{ WBK 1.0} & 1 & 8 & 52 & $\begin{array}{l}18.4 \\
(0.2)\end{array}$ & $\begin{array}{c}3.23 \\
(0.02)\end{array}$ \\
\hline & 2 & 20 & 70 & $\begin{array}{l}18.6 \\
(2.6)\end{array}$ & $\begin{array}{c}2.86 \\
(0.15)\end{array}$ \\
\hline & 3 & 20 & 87 & $\begin{array}{l}28.4 \\
(3.8)\end{array}$ & $\begin{array}{c}3.85 \\
(0.13)\end{array}$ \\
\hline WCK 6.8 & 1 & 8 & 54 & $\begin{array}{l}18.5 \\
(1.9)\end{array}$ & $\begin{array}{c}3.40 \\
(0.22)\end{array}$ \\
\hline
\end{tabular}

ayear 1 = June 1984-May 1985; year 2 - October 1985-July 1986; and year 3 = October 1986-July 1987.

bMeans of only samples collected in October 1984 and April 1985, for comparison with reference sites. 
used in the comparison with Bear Creek because the number of samples collected per site was similar in the two streams (Table 5-1). Especially noteworthy is the finding that the total number of taxa collected during all months at sites above SS5 did not exceed the total taxa collected at any of the other reference sites where considerably fewer samples were collected. The difference between Bear Creek and the reference sites is better illustrated in the second and third years when all streams were sampled at the same frequency. In both years 2 and 3 , more taxa were collected at the reference sites than at any Bear Creek site. During the second year, the total taxa collected at each reference site exceeded that of $B C K 3.25$ by at least one and that of the remaining Bear Creek sites by at least 15. During the third year, the total number of taxa collected at each reference site exceeded that of BCK 9.40 by at least 9 and that of the other Bear Creek sites by as much as 21 .

Mean richness (number of taxa per sample) displayed a spatial trend in Bear Creek similar to that of total richness (Table 5-5). During the Lirst year, mean richness was significantly greater at BCK 3.2 .5 (13.3 taxa/sample) than at all other Bear Creek sites. In years 2 and 3 , mean richness at $B C K 3.25$ and $B C K 9.40$ was not significantly different, averaging ar least 15.2 taxa/sample at the two sites (Appendix G, Table G-1). Mean richness was significantly lower at BCK 12.36 than at all other Bear Creek sites during all three years, and never exceeded 2.0 taxa/sample. With the exception of $\mathrm{BCK} 11.09$ in year 2, mean richness was significantly greater at those sites downstream of SS5 than at the upstream sites.

Mean richness of the reference sites exhibited few significant differences (Tables $5-5$ and G-2). During the first year, mean richness of the reference sites ranged from 12.6 to 24.3 taxa/sample. Mean richness at HCK 25.4 was significantly lower than that at only three other sites, but no other sites differed significantly. During the second year, mean richness ranged from 17.7 to 2.8 .0 taxa/sample.

Richness during this period was significantly higher at UTK 0.6 than at all sites except BTK 0.3 , and mean richness at GCK 2.4 was significantly lower than that at UTK 0.6 and BTK 0.3 . Mean richness during the third 
year ranged from 24.9 to 36.3 taxa/sample. During this period, richness was significantly higher at UTK 0.6 than at all other sites except

MBK 1.6. At MBK 1.6, richness was significantly greater than all sites except UTK 0.6 and PHK 1.4; no other sites were significantly different.

Comparisons of mean benthic invertebrate richness between the Bear Creek and reference sites showed that the mean number of taxa per sample was significantly lower at both BCK 11.83 and BCK 12.36 compared to the reference sites in all three years (Tables G-3 through G-5). During the second and third years, mean richness was significantly lower at BCK 11.09 than at all reference sites, while during the first year, the difference was significant for all but three sites. Mean richness at BCK 9.91 was significantly lower than that of all reference sites during the third year, and significantly lower than all but one and two reference sites during the first and second years, respectively. Sites downstream of SS5 differed little statistically from the reference sites during the first and second years. During the third year, however, mean richness was significantly lower at BCK 3.25 and $B C K 7.87$ than that of all reference sites and was significantly lower at BCK 9.40 than that of only two reference sites.

Within-site comparisons between years showed that the mean richness of benthic invertebrates at each Bear Creek site except BCK 12.36 was significantly greater during the second and third years of the study than during the first year (Table 5-5 and Table G-6). Mean richness at BCK 7.87, BCK 9.40, and BCK 11.83 was significantly greater during the second than the third year, while no difference between these two years was found for the remaining Bear Creek sites.

The reference sites exhibited annual trends in mean richness that were similar to those in Bear Creek (Table G-7). With the exception of PHK 1.4, mean richness was significantly greater during the third year than during the first year at all reference sites. Although mean richness was not significantly different between years 1 and 2 at BTK 0.3 , GHK 2.9, MBK 1.6, PHK 1.4, and WBK 1.0, it was significantly higher in the second year than during the first year at CCK 0.6 , GCK 2.4, GHK 1.6, and UTK 0.6. Richness during the third year was significantly higher than richness during the second year at all sites but BTK 0.3 . 
Considerable seasonal variability was observed in the mean number of taxa per sample at all Bear Creek and reference sites (Figs. 5-5 and 5-6). Most sites, including Bear Creek and the reference streams, appeared to exhibit peaks in the mean number of taxa during the spring and/or fall. BCK 12.36 exhibited very little seasonality in taxonomic composition, but any changes that did occur were observed during the spring. The mean number of taxa/sample consistently exceeded 15 during each sampling period at BCK 3.25, and sometimes exceeded 15 at BCK 9.40 . At the remaining sites, the mean number of taxa rarely or never exceeded 15, and at BCK 12.36, the mean number of taxa exceeded 2 during only 3 sampling periods. At the reference sites, however, the mean number of taxa/sample was rarely less than 15 and frequently exceeded 20 at many sites.

\subsubsection{Species Diversity}

As with richness, mean species diversity exhibited a general. increase with increasing distance from the $\mathrm{Y}-12 \mathrm{Plant}$ in all three years (Table 5-5). The greatest diversity occurred at BCK 3.25, where values were near or greater than 3.0 in all three years. Diversity at BCK 3.25, however, did not differ significantly from that at BCK 7.87 where mean values remained below 3.0 in all three years. No significant difference was observed between BCK 7.87 and BCK 9.40 in any year (Table G-8). Diversity was lowest at BCK 12.36 in all three years where values never exceeded 1.0. Except for $B C K 11.83$ during the first year, diversity at BCK 12.36 was significantly lower than that of all other Bear Creek sites in all years.

Four statistically significant differences in mean diversity occurred between the reference sites, and there were no consistent patterns of difference (Table 5-5 and Table G-9). Mean diversity values for the reference sites ranged from 2.63 to 4.05 and were rarely less than 3.0 .

Results of statistical comparisons between the Bear Creek and reference sites are presented in Tables G-10 through G-12. Mean diversity at both $B C K 11.83$ and $B C K 12.36$ was significantly lower than that of the reference sites in all years. In year 1 , diversity at 


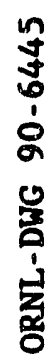
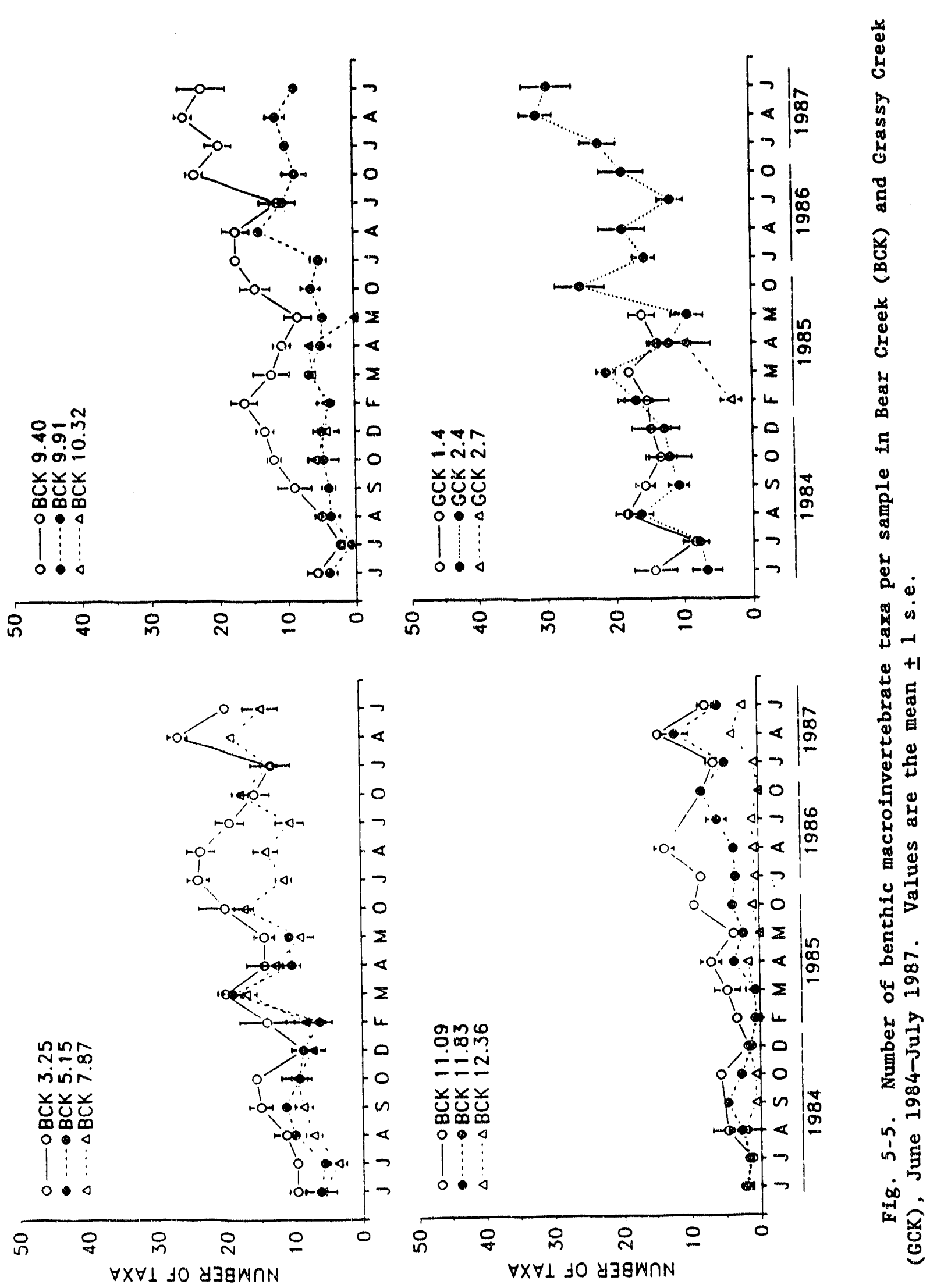


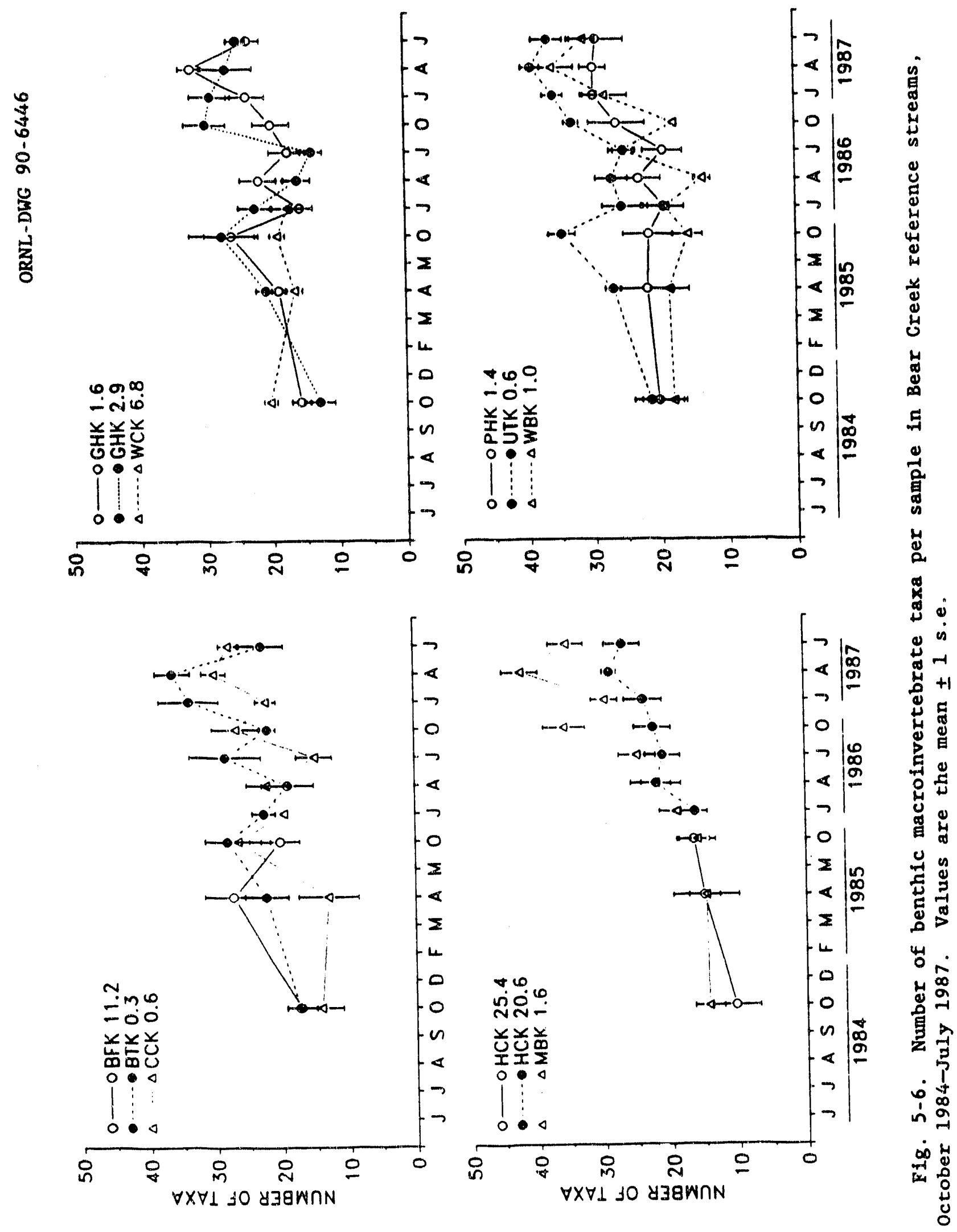


BCK 9.91 and BCK 11.09 differed significantly from some but not all reference sites. In years 2 and 3 , diversity at these two sites was significantly lower than that of all reference sites except WBK 1.0 , where no significant difference was found between this site and BCK 11.09 in year 2. Diversity at BCK 9.40 was significantly lower than that of only one reference site during the first year and two reference sites during the second year. During the third year, BCK 9.40 differed from all reference sites. During years 1,2 , and 3 , mean diversity at BCK 7.87 was significantly lower than that of one, two, and six reference sites, respectively. No significant difference was found between $B C K \quad 3.25$ and any reference sites in any year.

Within-site comparisons of annual changes in mean diversity showed that diversity in Bear Creek during the third year was significantly greater than diversity during the first year, except at BCK 11.09 where no year-to-year differences were found (Table G-6). Iikewise, diversity during the second year was significantly greater than diversity of the first year, except at BCK 11.09, BCK 11.83, and BCK 12.36; diversity was significantly higher in the third year compared to the second year at the latter two sites (Table G-6).

As in Bear Creek, year-to-year differences occurred in some reference streams where diversity was usually significantly highex during the latter two years compared with the first (Table G-7). Significant differences were found between years 2 and 3 only at GCK 2.4, MBK 1.6, and WBK 1.0 where diversity was greater in year 3 than in the preceding year.

Along with the number of taxa per sample, diversity exhibited considerable seasonal variability in Bear Creek and the reference sites (Figs. 5-7 and 5-8). Peaks in diversity typically occurred during the spring and/or fall. Diversity at BCK 3.25 consistently exceeded 2.5, and during 1986 and 1987, was above 3.0 most of the time. While diversity exceeded 2.0 at $B C K 7.87$ and $B C K 9.40$, it was usually less than 2.0 above SS5. Diversity at BCK 12.36 exceeded 1.0 in only one month. The reference sites had diversity values that were consistently greater than 3.0 , and some sites had values that exceeded 4.0 on occasion. 

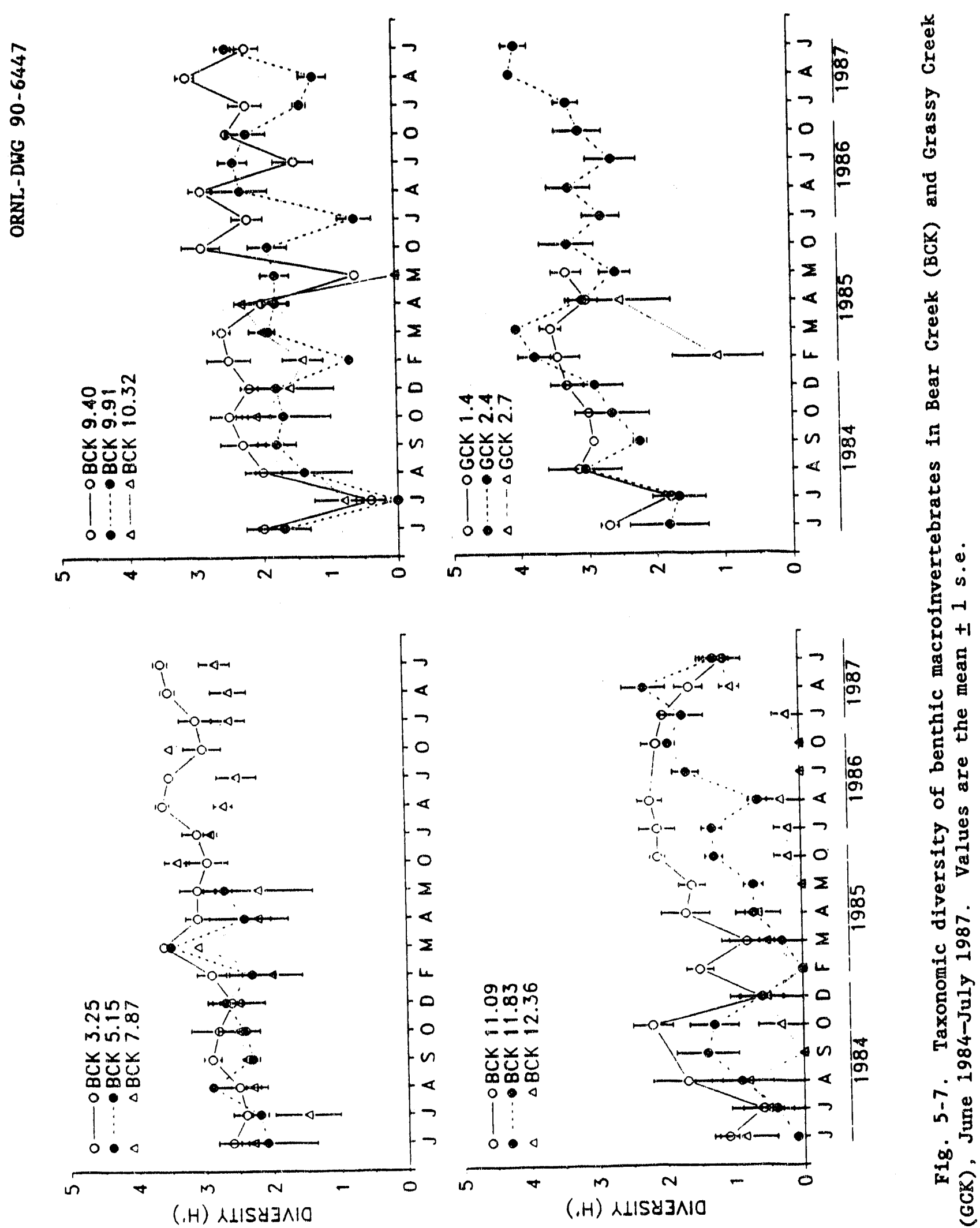

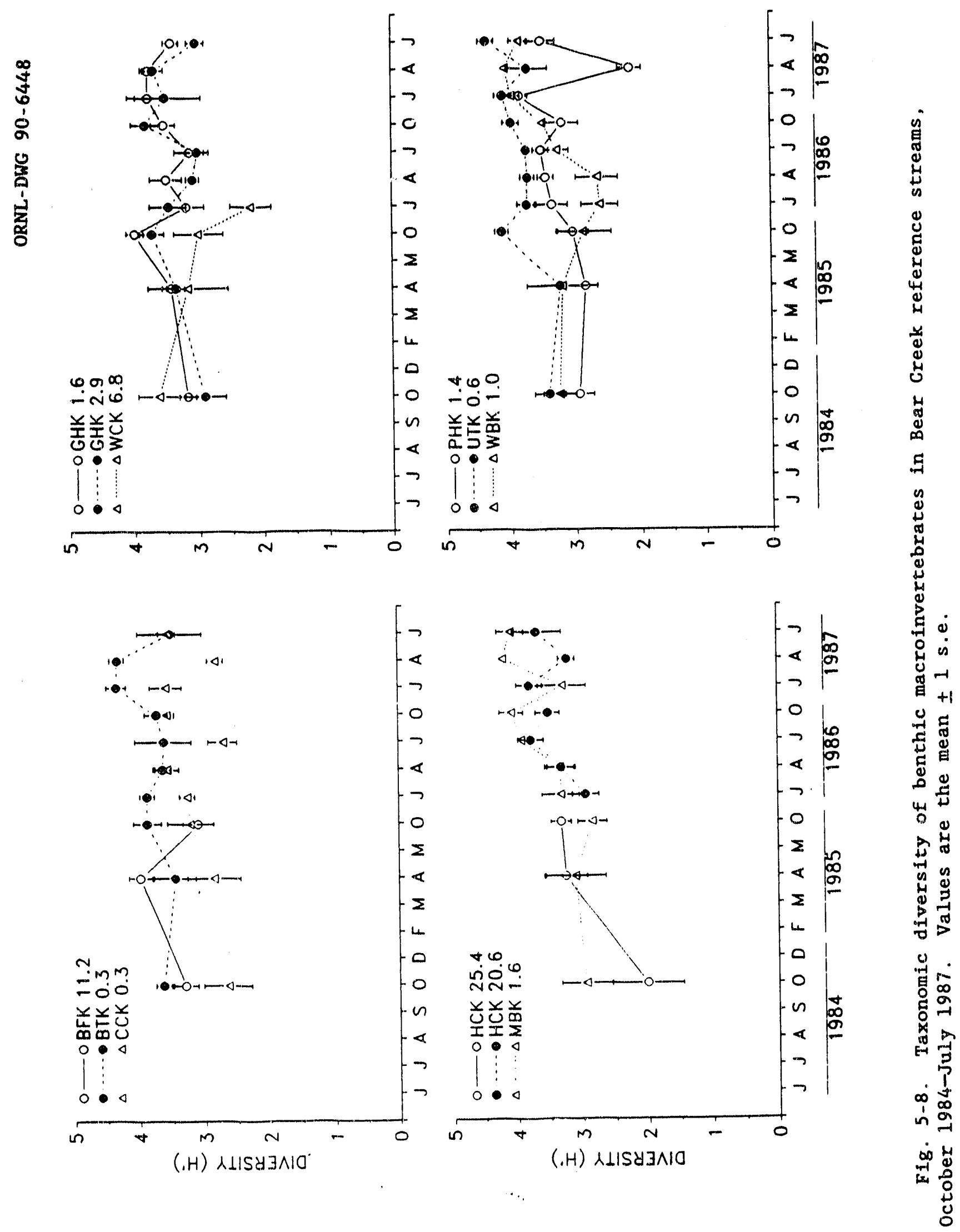


\subsection{DISCUSSION}

Considerable chan in the benthic macroinvertebrate community occurred from the upper in the lower reaches of Bear Creek. Density, biomass, taxonomic richness, and taxonomic diversity all increased with increasing distance downstream from the Y.12 Plant, and, in most cases, reached maxima at the lowest site, $B C K$ 3.25. Change in the benthic invertebrate community along a longitudinal gradient is a natural characteristic of streams (e.g., Hynes 1970). The richness and diversity of invertebrates, for example, should generally increase with increasing stream size before reaching maxima in about fourth- to sixthorder streams (e.g., Vannote et al. 1980; Ward and Stanford 1983). Thus, for a stream the size of Bear Creek, which is a third-order stream at $\mathrm{BCK} 3.25$, an increase in richness and diversity would be expected over its entire length.

Although spatial changes occur naturally in the benthic macroinvertebrate communities of streams, the magnitude of change observed between the upper and lower reaches of Bear Creek and the substantial differences found between much of Bear Creek and the reference streams are indicative of degraded conditions. Maximum impact was observed in all years at BCK 12.36 where density, biomass, richness, and diversity of the benthic community were all significantly lower than for other Bear Creek sites and reference streams (the only exception was the absence of any significant difference in diversity between this site and BCK 11.83 in year 1 ). Values obtained at BCK 12.3 for density, biomass, richness, and diversity were consistently some of the lowest observed for any stream on the ORR, with the possible exception of the midreaches of Mitche 11 Branch at the Oak Ridge Gaseous Diffusion Plant (ORGDP) and the lower reaches of Fifth Creek at OR $\mathrm{l}$. J. M. Loar, ORNL/ESD, 1988, and J. G. Smith, ORNL/ESD, 1988, asonal comunication to G. R. Southworth, ORNL/ESD).

Downstream of $B C K 12.36$, the benthic invertebrate community gradually improved, as demonstrated by increases in density, biomass, richness, and diversity. Gradual improvement was also shown by increases in the richness and relative abundance of stoneflies (Plecoptera) and caddisflies (Trichoptera), two groups of aquatic 
insects that are generally indicative of moderately clean to unpolluted conditions (e.g., Hynes 1960; Wiederholm 1984; Hilsenhol1 2987). Improvement was most remarkable at those sites downstrean of SS5 (BCK 3.25, BCK 5.15, BCK 7.87, and BCK 9.40). With few exceptions, these sites usually had significantly higher density, biomass, richness, and diversity than the upstream sites and showed fewer significant differences from the reference sites. Additionally, those sites upstream of SS5 were numerically dominated by dipteran (flies) larvae of the family Chironomidae, a group of small insects that comprised greater than 688 of the density at each site in all years. Numerical dominance of chironomids is typical of polluted streams (e.g., Winnex et al. 1.980; Wiederholm 1984), a pattern that has also been observed in other impacted streams on the ORR (J. M. Loar, ORNL/ESD, 1988, and J. G. Smith, ORNL/ESD, 1988, personal communication to G. R. Southworth, ORNL/ESD).

Although substantial improvement was observed in the benthic community at those sites downstream of SS5, the low total richness of invertebrates and the low richness and relative abundance of mayflies (Ephemeroptera) at these sites relative to the reference sites suggest that, as water quality improves, further enhancements in the community are probable, at least at those sites above BCK 3.25. During the second and third years, when Bear Creek and the reference sites were sampled at the sane frequency, the total number of taxa collected at each of the reference sites exceeded that for BCK 9.60 and BCK 7.87 by at least nine. The total number of mayfly taxa collected at the two sites by quantitative sampling during the 3-year study period was two and three, respectively; and their relative density did not exceed $0.8 \%$. At the reference sites, on the other hand, no fewer than five mayfly taxa were collected during any one year, and at most sites eight or more taxa were collected. Additionally, no fewer than nine mayfly taxa were collected during the entire study at each reference site, and with few exceptions, their relative abundance exceeded 7.08. Like stoneflies and caddisflies, mayflies are generally intolerant of poor water quality (e.g., Hynes 1960; Wiederholm 1984; Hilsenhoff 1987).

The greatest amount of improvement in the benthic community of Bear Cropk was exhibited at BCK 3.25: the site farthest from the 
Y-12 Plant. In general, density, biomass, mean richness, and diversity at this site differed little from the reference sites, except during the third year when mean richness and biomass were lower than most of the reference sites. Although the total number of taxa collected at $\mathrm{BCK} 3.25$ in all years was generally low relative to the reference sites, the number of pollution-intolerant taxa, such as caddisflies, mayflies, and stoneflies, and their relative abundances were similar between Bear Creek and the reference streams. Also found at this site were relatively high densities of the snail Elimia. This snail has been observed only in the relatively unpolluted streams sampled in this study and other studies on the ORR (J. M. Loar, ORNL/ESD, 1988, personal communication to $G$. R. Southworth, ORNL/ESD). These results suggest that the benthic invertebrate community in Bear Creek approximately $9.5 \mathrm{~km}$ below the $\mathrm{S}-3$ ponds is comparable to the communities of nearby unimpacted streams, and thus only minimally influenced by past and present operations at the Y-12 Plant.

There was little evidence that the benthic invertebrate community at any site in Bear Creek had changed in a manner indicative of either improving or degrading water quality conditions since 1984. The benthic communities of Bear Creek and the reference streams generally exhibited similar year-to-year changes in density, biomass, species composition, and cormunity structure, and proportions of the dominant taxa remained relatively stablc from year to year. For example, density, biomass, richness, and diversity tended to increase at most Bear Creek and reference sites over the course of the study. This trend was probably due to a combination of (1) natural annual changes in the benthos and (2) improvements in sample processing procedures. During the first year of the study, invertebrates were sorted from the samples without the aid of magnification, which may have caused some of the smaller organisms to be overlooked. In subsequent years, organisms were sorted with the aid of a $2 x$ illuminated magnifying lamp. This change in procedure should have increased the probability of finding smaller organisms, resulting in increases in at least density and richness but not necessarily biomass and diversity. Results over the 3-year study period indicate that, in general, such changes did occur. 
The presence of one or more toxicants may be responsible for the adverse effects that were observed on the structure and composition of the benthic invertebrate community in the upper reaches of Bear Creek [i.e., very low density, biomass, diversity, and richness (e.g., Wiederholm 1984)]. With increasing distance downstream, density, biomass, diversity, and richness tended to increase, thus indicating a reduction in toxic conditions. These results are consistent with those obtained in toxicity tests with Ceriodaphnia (Tables 3-6 and 3.8), but the toxicity tests were unable to demonstrate that toxic conditions existed in the midreaches of Bear Creek. Further evidence that toxic conditions existed but diminished with increasing distance downstream was demonstrated by an increase in the number of taxa that are generally intolerant of poor water quality (e.g., stoneflies and caddisflies). However, other major groups of organisms, such as mayflies and snails, were either absent or a minor component of the community, except at BCK 3.25, the most dowrstream site.

The almost total absence of mayflies everywhere except BCK 3.25 and the relatively high abundance of caddisflies and stoneflies at some sites upstream of $B C K 3.25$ suggest that the patterns exhibited by the benthic invertebrate community were primarily the result of heavy metal contamination in the upper reaches of Bear Creek. This hypothesis is consistent with the finding that some metals are elevated in Bear Creek, particularly in the upper reaches (Sect. 2.1.1.2). Mayflies appear to be one of the most sensitive groups of insects to heavy metal pollution, while some chixonomids apparently are among the mosi tolerant species. Between these two extremes are caddisflies, which can tolerate moderate amounts of metal pollution (Wiederholm 1984). Some stoneflies (e.g., some species of Amphinemura) are tolerant of low $\mathrm{pH}$ conditions under which the effects of heavy metals are sometimes difficult to separate (Wiederholm 1984). The occurrence of some stoneflies in upper Bear Creek, where low pH apparently is no longer a prcblem (Sect. 2.1.1.2), suggests that this group of insects may be similar to the caddisflies by being moderately tolerant of heavy metal poilution. Additional perturbations may also be influencing the benthic community in Bear Creek, including siltation, very high concentrations 
of dissolved inorganic salts and nitrates, and, at $\mathrm{BCK} 9.91$, volatile organics (see Sect. 2.1.1.1). Perturbations such as these can influence a benthic community by altering its structure and either raising or lowering densities (e.g., Wiederholm 1984). The effects of metals, however, appear to be overriding any major effects that most of these additional perturbations may be having on the benthos of Bear Creek. For example, limited data from EFPC indicate that overall metal concentrations are much lower in that stream than in Bear Creek (Table 2-4; J. M. Loar, ORNL/ESD, 1988, personal communication to G. R. Southworth, ORNL/ESD, Table 2-2). Considerable siltation is present in EFPC, and elevated concentrations of nitrate and some organics occur just downstrearn of the Y-12 Plant. In EFPC, one species each of a mayfly (Baetis sp.) and caddisfly (Hydropsyche depravata) begins to appear in relatively high densities approximately 6 and $10 \mathrm{~km}$, respectively, from the outfall of Lake Reality at the east end of the Y-12 Plant, (J. M. Loar, ORNL/ESD, 1988, and J. G. Smith, ORNL/ESD, 1988, personal communication to G. R. Southworth, ORNL/ESD). At least one additional mayfly species (Stenoma sp.) is also common $10 \mathrm{~km}$ downstream of the plant. Stoneflies, however, are rarely collected in EFPC at any site. Some caddisflies (such as members of the family Hydropsychidae) are moderately tolerant of siltation, elevated metals, and nutrient enrichment; some mayflies (such as members of the family Baetidae) are moderately tolerant of siltation and nutrient enrichment but not metals; and some stoneflies appear to be moderately tolerant of metals and siltation, but less tolerant of nutrient enrichment (Winner et al. 1980; Wiederholm 1984; Hilsenhoff 1987). Thus, if siltation, organics, and/or nitrates were an important limiting factor, at least in the middle reaches Jf Bear Creek, one would not expect to find stoneflies. Likewise, if metals were a factor in the mid and lower reaches of EFPC, one would not expect to find mayflies.

In addition to the possible presence of toxicants, the absence of suitable habitat for invertebrate colonization may also be causing the low density, biomass, richness, and diversity at BCK 12.36. Substratum is a primary factor influencing the abundance and distribution of invertebrates (e.g., Hynes 1970). Results of some studies indicate that, as the substrate becomes more heterogeneous, the number and $t$ pes 
of invertebrates increase (Minshall 1984), suggesting that the lack of available habitat at BCK 12.36 could be an important limiting factor for the benthic community at this site.

One add. timnal factor that may also have influenced the benthic community dis beate Creek was the drought, which caused many reaches of Bear Creek to become dry for various periods of time (Fig. 2-4). Many invertebrates have mechanisms that allow them to survive dry periods (e.g., variability in life cycles, behavioral avoidance such as burrowing in the substrate, diapause) and to recolonize the stream once water returns (Williams 1987). Therefore, if any Bear Creek sites were adversely affected by the drought, different seasonal and/or annual trends in density and species richness would be expected between the affected and nonaffected sites. However, different trends were not observed between those sites most affected by the drought (BCK 9.91 and BCK 11.09) and other Bear Creek or reference sites. 


\section{FU'TURE ECOLOGICAL CONDITIONS}

\subsection{REMEDIAL, ACTIONS AND OTHER EXPECTED CHANGES}

Ongoing and future efforts to remediate envixonmental contamination in Bear Creek Valley could affect the ecological status of Bear Creek. Major remedial actions were recently implemented at the $\mathrm{s}-3$ pond site, the oil landfarm, the burial grounds, and the PCB-contaminated ponds and tributaries draining the burial grounds.

of these remedial programs, the actions at the S-3 ponds probably have tho greatest potential for affecting Bear Creek. Recent actions taken at this site include filling and covering the ponds with an impermeable clay cap. Future actions could include withdrawing groundwater from the contaminated plume and discharging it, after treatment, to the upper EFPC. Capping the $S-3$ ponds may result in more rapid improvement in water quality in upper Bear Creek than would have occurred if no action had been taken, but the magnitude and rate of improvement are uncertain (White et al. 1989). Groundwater withdrawals would improve water quality at sites several kilometers downstream from the S-3 ponds but are likely to dewater Bear Creek's upper reaches (which now have permanent flow but appreciable toxicity) much of the time.

Remedial actions at the oil landfarm and burial grounds include capping an extensive area with an impermeable cover, possibly coupled with a future groundwater withdrawal and treatment system. The treated groundwater would be discharged to either Bear Creek or EFPC. Impacts on Bear Creek would result from changes in flow duration response to precipitation due to the impermeable cover over a substantial portion of the watershed, or from increased flow and thermal stability if treated groundwater is discharged to Bear Creek. However, if treated

groundwater is discharged to EFPC, Bear Creek will be adversely affected by reduction in base flow. Construction and operation of a borrow pit to provide material for constructing a clay cap, combined with rapid runoff of rainwater from the capped portions of the watershed, are likely to increase erosion and sedimentation in Bear Creek downstream from these sites. 
Efforts to remediate $\mathrm{PCB}$ contamination within Bear Creek watershed initially focused on removal of the $\mathrm{PCB}$-contaminated sediments in ponds and tributaries in the burial grounds, with capping and leachate collection/treatment to prevent renewed contamination of these systems. Further investigation of the extent of PCB contamination in the Bear Creek floodplain will be conducted and may indicate a need for remedial action.

\subsection{ANTICIPATED ECOLOGICAL CHANGES}

Several remedial action plans ha e been developed to address ecological problems in Bear Creek, each with a different potential impact on the aquatic and benthic communities. The primary options include treatment of groundwater, removal of sediments, and construction activities in the Bear Creek area. The potential effects of each option are discussed below.

As part of the remedial activity associated with contamination from the $?$ ponds, several options are being evaluated to treat groundwater plumes in the upper Bear Creek area. Some options will remove enough water from Bear Creek to dewater the stream above SS5 for extended periods of time and to discharge this water to EFPC. Obviously, impacts on the fish and benthos populations from such options would be significant in the dewatered area. Although flow in much of this reach of Bear Creek is already intermittent, the removal of additional water could eliminate some fish spawning and nursery habitat. The Telmessee dace, known formerly as the mountain redbelly dace, is listed a:i in need of management with protection of its habitat by the Tennessee Wildlife Resources Agency and occupies most of Bear Creek upstream of the NPDES monitoring station at BCK 4.55. Because removal of water would affect the shallow spawning and nursery areas first, groundwater removal, treatment, and discharge to EFPC could have severe consequences for the Tennessee dace. Although the exact spawning habitat of the Tennessee dace is not known, (D. A. Etnier, University of Tennessee, 1987, personal communication to M. G. Ryon, ORNL/ESD) indicates that it spawns in gravel riffles. It may also use shallow-riffle-pools transition areas for spawning (M. G. Ryon, ORNL/ESD, personal observation) and 
shallow backwater areas and margins of pools for the rearing of larvae and juveniles. All those areas could be substantially dewatered by groundwater pumping and discharge outside the watershed. The effects of water removal could possibly extend downstream of SS5.

Groundwater removal and treatment in Bear Creek Valley could also alter the existing stream temperature regime. Many of the fish species in Bear. Creek are cool-water species and an increase in temperature could be detrimental. For example, water temperature limits the distribution of the blacknose dace and the bancied sculpin in other area streams. The blacknose dace has an upper lethal temperature of approximately $29^{\circ} \mathrm{C}$ (Hart 1952; Terpin et al. 1976) and the sculpin is limited to areas with low mean temperatures (Becker 1983). Although it is capable of tolerating rapid temperature changes (Matthews and Styron 1981), the Tennessee dace is normally found in spring-fed streams and could be impacted by extended periods of increased temperature. Some areas of upper Bear Creek presently experience high temperatures. With less grourdwater entering the stream and reduced flow, solar heating may be sufficient to raise temperatures to problematic levels.

Other remediation-related activities, such as road construction, clearing of large land areas, and installation of clay caps could reduce available habitats in Bear Creek. Effects of sedimentation are already discernible in upper Bear Creek in the vicinity of BCK 12.36. The bottom substrate in this section of the stream has been covered by sediment, resulting in a reduction of cover. Also, the increased turbidity associated with erosion and runoff from construction sites could be detrimental to those species adapted to clear-water systems (e.g., the Tennessee dace). The sedimentation problems would not be as limited as the dewatering problems, and it could impact the entire area of Bear Creek above the weir at BCK 4.55 .

\subsection{FUTURE RESEARCH NEEDS}

Routine quantitative sampling to determine density, biomass, and richness of the fish populations in Bear Creek will be continued. Sampling will be conducted on a semiannual basis (spring and fall) at the same sites that were sampled in 1985-1987 (see Table 4-3). 
Qualitative sampling will be limited to stream areas not covered by the quantitative sampling.

In addition to this routine sampling, additional studies and procedures will be implemented for the purpose of impact characterization. To further assess the significance of habitat differences as determinants of fish species 1 ichness and abundance, the substrate and cover will be characterized at each site during normal flow in the same manner as that described in Sect. 2.3.2 for low flows. Additional techniques will be applied to the existing data sets to assess impacts (e.g., calculation of species diversity indices and the Index of Biotic Integrity). Ëstimates of production will also be made using the procedures of Garman and Waters (1983), as adapted and documented in Railsback et al. (1989).

Experimental studies will also be included as a component of the Bear Creek ecological monitoring program on the future. The use of length-frequency histograms failed to provide definitive answers regarding differences in fish growth betwet. sites. Because growth can be an important measure of toxic effects in fish, differences among sites may be evaluated using short-term growth comparisons with a cyprinid species (e.g., the Tennessee dace), if an acceptable protocol can be developed. Such a protocol may include in situ enclosure to measure growth at weekly or biweekly intervals. As part of this growth evaluation, an attempt will be made to age cyprinid species by the analysis of scales taken from fish in the fall. The importance of the Tennessee dace as a species protected by the state of Tennessee suggests that addicional studies be directed at defining its habitat and principal life-history attributes. Few data are available regarding its spawning requirements and juvenile habitat, which could be important in evaluating remedial action alternatives related to groundwater treatment.

Because of their sensitivity to changes in water quality, continued monitoring of benthic invertebrates will provide a good indication of the effectiveness of remedial actions. Sampling of the benthos at the seven Bear Creek sites that were studied during the second and third years will continue at quarterly intervals. Samples were collected 
through July 1988 at the same 10 reference sites used in the second and third years. In subsequent years, however, the number of reference sites used will be reduced to five. These reference sites tentatively will include Grassy Creek (GCK 2.4), Gum Hollow Creek (GHK 1.6 and GHK 2.9), Mill Branch (MBK 1.6), and UT Farm Creek (UTK 0.6). Retention of only these five sites will continue to provide a range of conditions similar to Bear Creek in terms of stream size and habitat type, as well as a wide range of biological conditions that might be expected in natural undisturbed streams of the Oak Ridge area. Various criteria were used to determine which reference streams should be eliminated, including: (1) relatively dissimilar substratum (BTK 0.3 and PHK 1.4); (2) stream size much larger than any Bear Creek site (HCK 20.6, a very large third-order site compared with lower Bear Creek at BCK 3.25, a relatively small third-order site); and (3) stream or watershed is used extensively by the public or for research (CCK 0.6 and WBK 1.0 ).

Benthic macroinvertebrate data analysis will continue to key on aspects of the community, especially the status of the mayflies. In addition, other indices will be used to monitor the status of the benthic community in Bear Creek, such as similarity indices, which will be useful for following within-site changes occurring from year to year. 


\section{REFERENCES}

Angermeier, P. L., and J. R. Karr. 1984. Relationships between woody debris and fish habitat in a small warmwater stream. Trans. Am. Fish. Soc. 113:716-726.

Altshuller, A. P., and R. A. Linthurst (eds.). 1984. The acidic deposition phenomenon and its effects: Critical assessment review papers, Vo1. II: Effects Sciences. EPA-600/8-83-016BF. Office of Research and Development, U.S. Environmental Protection Agency, Washington, D.C.

Bain, M. B., J. T. Finn, and H. E. Booke. 1985. Quantifying stream substrate for habitat analysis studies. N. Am. J. Fish Manage. $5: 499-500$.

Bain, M. B., J. T. Finn, and H. E. Booke. 1988. Streamflow regulation and fish community structure. Ecology 69:382-392.

Baltz, D. M., B. Vondracek, L. R. Brown, and P. B. Moyle. 1987. Influence of temperature on microhabitat choice by fishes in a California stream. Trans. Am. Fish. Soc. 116:12-20.

Becker, G. C. 1983. The Fishes of Wisconsin. University of Wisconsin Press, Madison, Wisconsin.

Burris, J. A. 1987. Survival and behavioral responses of the snail Elimia clavaeformis (Lea) in a metal-contaminated stream. M.S. thesis. University of North Carolina, Chapel Hill, North Carolina.

Burris, J. A., M. S. Bamford, and A. J. Stewart. 1990. Behavioral responses of marked snails as indicators of water quality. Environ. Toxicol. Chem. 9 (in press).

Burrows, W. D. 1977. Aquatic aluminum: Chemistry, toxicology, and environnental prevalence. IN: CRC Critical Reviews in Environmental Con'rol, Vol. 7(2):167-216. 
Callahan, M. A., M. W. Slimak, N. W. Gabe1, I. P. May, C. F. Fowler, J. R. Freed, P. Jennings, R. L. Durfee, F. C. Whitmore, B. Maestri, W. R. Mabey, B. R. Holt, and C. Gould. 1979. Water-related environmental fate of 129 priority pollutants, Vol. I:

Introduction and Technical Background, Metals and Inorganics, Pesticides and PCB. EPA-440/4-79-029a. U.S. Environmenta1 Protection Agency, Washington, D.C.

Carle, F. L., and M. R. Strub. 1978. A new method for estimating population size from removal data. Biometrics 34:621-630.

Cooper, E. L. 1983. Fishes of Pennsylvania and the Northeastern United States. Pennsylvania State University Press, University Park, Pennsylvania.

Cüshman, R. M., S. G. Hildebrand, R. H. Strand, and R. M. Anderson. 1977. The toxicity of 35 trace elements in coal to freshwater biota: A data base with automated retrieval capabilities. ORNL/TM - 5793.

Diamond, J, M. 1975. Assembly of species communities. pp. 342-344. IN: M. L. Cody and J. M. Diamond (eds.), Ecology and Evolution of Communities. Belknap Press, Harvard University Press, Cambridge, Massachusetts.

Driscoll, C. T., J. P. Baker, J. J. Bisogni, and C. L. Schofield. 1980. Effect of aluminum speciation on fish in dilute acidified waters. Nature 284:161-164.

Eliott, J. M. 1977. Some methods for the statistical analysis of samples of benthic invertebrates. Sci. Pub. No. 25. Freshwater Biological Association, Ambleside, England.

Energy Research and Development Administration (ERDA). 1975. Preliminary draft environmental analysis - Oak Ridge Operations, Vo1. VI, Section 2.5.5.

Environmental Affairs Department (EAD). 1984. Monitoring data from upper Bear Creek. Y/TS-45. Y-12 Plant, Oak Ridge, Tennessee. Enviroumental Protection Agency (EPA). 1976. Quality Criteria for Water. U.S. Environmental Protection Agency, Washington, D.C. Environmental Protaction Agency (EPA). 1980. Water quality criteria for toxic substances. Fed. Regis. 45(231):79317-79379. 
Environmental Protection Agency (EPA). 1986. Quality criteria for water, 1986. EPA 440/5-86-001. Office of Water Regulations and Standards, U.S. Environmental Protection Agency, Washington, D.C.

Environmental Protection Agency (EPA). 1988a. Summary of water quality criteria for aluminum. Fed. Regis. 53(168):33177-33179.

Environmental Protection Agency (EPA). 1988b. Summary of water quality criteria for chloride. Fed. Regis. 53(102):19028-19030.

Exxon Nuclear, Inc. 1976. Exxon Nuclear Fuel Recovery and Recycling Center Environmental Report, Vols. I-II. Docket No. 50-564, December 16 .

Foltz, J. W. 1982. Fish species diversity and abundance in relation to stream habitat characteristics. Southeast Assoc. Fish. and Wildl. Agencies 1982:305-311.

Garman, G. C., and T. F. Waters. 1983. Use of the size-frequency (Hynes) method to estimate annual production of a stream fish population. Can. J. Fish. Manage. 6:176-182.

Gatz, A. J., Jr., and J. M. Loar. 1988. Petersen and removal population size estimates: Combining methods to adjust and interpret results when assumptions are violated. Environ. Biol. Fishes 21:293-307.

Gorman, 0. T., and J. R. Karr. 1978. Habitat structure and stream fish communities. Ecology 59:507-515.

Greeson, P. E., T. A. Ehlke, G. A. Irwin, B. W. Lium, and K. V. Slack. 1977. Methods for collection and analysis of aquatic biological and microbiological samples. Book 5, Chapter 4A, pp. 1-332.

IN: U.S. Geological Survey, Techniques of Water-Resources Investigations of the United States Geological Survey. U.S. Government Printing Office, Washington, D.C.

Hart, J. S. 1952. Geographic Variations of Some Physiological and Morphological Characters in Certain Freshwater Fish. University of Toronto Biological Series No. 60. University of Toronto Press, Toronto. 
Health, Safety, Environment, and Accountability Division (HSEAD). 1985. Analytical data on groundwater, surface water, and sediment samples taken in the Y-12 Plant Bear Creek Valley waste disposal areas.

Y/TS-88. Y-12 Plant, Oak Ridge, Tennessee.

Hile, R. 1936. Age and growth of the cisco, Leucichthys artedi (LeSeur), in the lakes of the northeastern highlands, Wisconsin. U.S. Bur. Fish. Bull. 48:211-31.7.

Hilsenhoff, $W$. L. 1987. An improved biotic index of organic stream poliution. Great Lakes Entomol, 20:31-39.

Horning, W. B., and C. I. Weber. 1.985. Short-term methods for estimating the chronic toxicfty of effluents and receiving waters to freshwater organisms. EPA/600/4-85/014. U.S. Environmental Protection Agency, Cincinnati.

Hynes, H. B. N. 1960. The Biology of Polluted Waters. University of Toronto Press, Toronto.

Hynes, H. B. N. 1970. The Ecology of Running Waters. University of Toronto Press, Toronto.

Jeter, I. W. 1983. The chemical and radiological characterization of the S-3 ponds. Y/MA-6400. Union Carbide Corporation Nuclear Division, Y-12 Plant, Oak Ridge, Tennessee.

Karr, J. R. 1.981. Assessment of biotic integrity using fish communties. Fisheries 6:21-27.

Karr, J. R., K. D. Fausch, P. L. Angermeier, P. R. Yant, and I. J. Schlosser. 1986. Assessing biological integrity in running waters: A method and its rationale. Speclal Publication 5.

Illinois Natural History Survey, Champaign, Illinois.

Karr, J, R. 1987. Biological monitoring assessment: A conceptual framework. Environ. Manage. 22:249-256.

Kornegay, F. C., D. C. West, R. A. Evans, S. T. Goodpasture, M. F. Tardiff, and A. R. Wilson, 1991. Oak Ridge Reservation Environmental Report for 1990. ES/ESH-18/V1. Office of Environmental Compliance and Documentation, Oak Ridge National Laboratory, and Environmental Management Staff, Oak Ridge Y-12 Plant and Oak Ridge Gaseous Diffusion Plant, Martin Marietta Energy Systems, Inc., Oak Ridge, Tennessee. 
Kornegay, F. C., D. C. West, S. T. Goodpasture, C. W. Kimbrough, M. F. Tardiff, V. A. Jacobs, and A. R. Wilson. 1990. Oak Ridge Reservation Environmental. Report for 1989. ES/ESH-13/V1. Office of Environmental Compliance and Docurnentation, Oak Ridge National. Laboratory, and Environmental Management Staff, Oak Ridge Y-12 Plant and Oak Ridge Gaseous Diffusion Plant, Martin Marietta Energy Systems, Inc., Oak Ridge, Tennessee.

Loar, J. M. (ed.). 1985. Application of habitat evaluation models in southern Appalachian trout streams. ORNI/TM-9323.

Lowery, J. F., P. H. Counts, H. L. Edmiston, and F. D. Edwards. 1986. Water resources data for Tennessee, water year 1985. Report No. USGS/WRD/HD-86/216. U.S. Geological Survey, Nashville, Tennessee. Lowery, J. F., P. H. Counts, H. L. Edmiston, and F. D. Edwards. 1987. Water resources data for Tennessee, water year 1986. Report No. USGS/WRD/HD-87/225. U.S. Geological Survey, Nashville, Ternessee. Lowery, J. F., P. H. Counts, H. L. Edmiston, and F. D. Edwards. 1988. Water resources data for Tennessee, water year 1987. Report No. USGS/WRD-HD-88/236. U.S. Geological Survey, Nashville, Tennessee. MacArthur, R. H. 1.972. Geographical Ecology: Patterns in the Distribution cf Species. Harper and Row, Inc., New York.

Matthews, W. J., and J. T. Styron, Jr. 1981. Tolerance of headwater vs mainstream fishes for abrupt physicochemical changes. Am. Midl. Nat. 105:149-158.

McClain, G. R. 1972. Preliminary aquatic survey of East Fork Poplar Creek, 1972. Report to Pollution Control Branch, U.S. Atomic Energy Commission, Oak Ridge, Tennessee.

McClendon, D. D., and C. F. Rabeni. 1987. Physical and biological variables useful for predicting population charactexistics of smallmouth bass and rock bass in an Ozark stream. N. Am. J. Fish. Manage. 7:46-56.

McMaster, W. M. 1967. Hydrologic data for the Oak Ridge area, Tennessee. U.S. Geological Survey-Water Supply Paper No. 1838-N. U.S. Government Printing office, Washington, D.C. 
Minsha11, G. W. 1984. Aquatic insect-substratum relationships. Pp. 358-400. IN: V. H. Resh and D. M. Rosenberg (eds.), The Ecology of Aquatic Insects. Praeger Publishers, New York.

Morton, R. T. 1978. Characterization of benthic macroinvertebrate communities influenced by winter reservoir drawdown and stream recovery. M.S. thesis. Tennessee Technological University, Cookeville, Tennessee.

National Oceanic and Atmospheric Administration (NOAA). 1985. Local climatological data: Monthly summaries for 1985, Oak Ridge, Tennessee. National Climatic Data Center, Asheville, North Carolina.

National Oceanic and Atmospheric Administration (NOAA). 1986. Local climatological data: Monthly summaries for 1986, Oak Ridge, Tennessee. National Climatic Data Center, Asheville, North Carolina.

National Oceanic and Atmospheric Administration (NOAA). 1987. Local climatological data: Monthly summaries for 1987, Oak Ridge, Tennessee. National Climatic Data Center, Asheville, North Carolina.

National Oceanic and Atmospheric Administration (NOAA). 1988. Local climatological data: 1987 annual summary with comparative data, Oak Ridge, Tennessee. National Climatic Data Center, Asheville, North Carolina.

Parr, P. D., and L. R. Pounds. 1987. Resource management plan for the Oak Ridge Reservation, Vol. 23: Oak Ridge National Environmental Research Park, Research Sites, and State Natural Areas. ORNL/ESH - 1/V23.

Petersen, C. G. J. 1896. The yearly immigration of young plaice into the Limfjord from the German Sea. Rep. Danish Biol. Station $6: 1-48$.

Pflieger, W. L. 1975. The Fishes of Missouri. Missouri Department of Conservation, Jefferson City, Missouri.

Pielou, E. C. 1977. Mathematical Ecology. John Wiley and Sons, New York. 
Platts, W. S., W. F. Megahan, and G. W. Minshal1. 1983. Methods for evaluating stream, riparian, and biotic conditions. U.S. Forest Service General Technical Report INT-138. Intermountain Forest and Range Experimental Station, Ogden, Utah.

Prater, B., and R. A. Hoke. 1980. A method for the blological and chemical evaluation of sediment toxicity. pp. 483-500. IN:

R. A. Baker (ed.), Contaminants and Sediments, Vol. 1: Fate and Transport, Case Studies, Modeling, Toxicity, Ann Arbor Science Publishers, Inc., Ann Arbor, Michigan.

Pulliam, P. J. 1985a. Water-quality data for 34 sites, April and June 1984, near the Y.I2 Plant, the Oak Ridge Reservation, Tennessee. U.S. Geological Survey Open File Report 85-165. U.S. Geological Survey, Nashville, Tennessee.

Pulliam, P. J. 1985b. Water-quality data for 35 sites, September 1984, near the Y-12 Plant, the Oak Ridge Reservation, Tennessee. U.S. Geological Survey Open File Report 85-553. U.S. Geological. Survey, Nashville, Tennessee.

Railsback, S. F., B. D. Holcomb, and M. G. Ryon. 1989. A computer program for estimating fish population sizes and annual production rates. ORNL/TM-11061.

Reece, J. H. 1973. Preliminary aquatic survey of East Fork Poplar Creek and Bear Creek, 1973. Report to Environmental Protection Branch, U.is. Atomic Energy Commission, Oak Ridge, Tennessee.

Ryon, M. G., and J. M. Loar. 1988. A checklist of fishes on the Department of Energy Oak Ridge Reservation. J, Tenn. Acad. Sci. 63:97-102.

SAS Institute, Inc. 1982. SAS User's Guide: Basics, 1982 ed. SAS Institute, Inc, Raleigh, North Carolina.

SAS Institute, Inc. 1985a. SAS User's Guide: Basics, Version 5 ed. SAS Institute, Inc., Cary, North Carolina.

SAS Institute, Inc. 1985b. SAS User's Guide: Statistics, Version 5 ed. SAS Institute, Inc, Cary, North Carolina.

Sheppard, J. D. 1974. Storm runoff in the vicinity of Oak Ridge, Tennessee. ORNL./TM-4662. 
Smith, P. W. 1979. The Fishes of Illinois. University of Illinois Press, Urbana, Illinois.

Starnes, W. C., and D. A. Etnier. 1980. Fishes, pp. B1-133. IN: D. C. Eager and R. M. Hatchers (eds.), Tennessee's Rare Wildiffe, Vo1. 1: The Vertebrates. Tennessee Wildife Resources Agency, Nashville, Tennessee.

Starnes, W. C., and R. E. Jenkins. 1988. A new cyprinid fish of the genus Phoxinus (Pices: Cypriniformes) from the Tennessee River drainage with comments on relationships and biogeography. Proc. Biol. Soc, Wash, 101:517-529.

Steel, R. G. D., and J. H. Torrie. 1960. Principles and Procedures of statistics, with Special Reference to the Biological Sciences. McGraw-Hill Book Company, Inc., New York.

Stewart, A. J. 1988. Alkalinity dynamics in a hard-water prairieinargin stream. Arch. Hydrobiol. 112:335-350.

Sun, P-C. P., J. H. Criner, and J. L. Poole. 1963. Large springs of East Tennessee. U.S. Geological Survey Water-Supply Paper No. 1755. U.S. Government Printing Office, Washington, D.C.

Ternessee Valley Authority (TVA). 1985. Instream contaminant study, Task 4: Fish sampling and analysis. Report to U.S. Department of Energy, Oak Ridge Operations Office. Tennessee Valley Authority, Office of Natural Resources and Economic Development, Knoxville, Tennessee.

Terpin, K. M., J. R. Spotila, and R. R. Koons. 1976. Effects of photoperiod on the temperature tolerance of the blacknose dace, Rhinichthys atratulus. Comp. Biochem. Physiol. 53A:241-244.

Turner, R. R., and G. E. Kamp. 1984. Characterization and remedial alternatives for sediments in upper Bear Creek. Y/TS-56.

Y-12 Plant, Oak Ridge, Tennessee.

Union Carbide Corporation - Nuclear Division (UCCND). 1977. Environmental monitoring report for calendar year 1976 , U.S. Energy Research and Development Administration Oak Ridge Facilities. Y/UB-6. Union Carbide Corporation Nuclear Division, Oak. Ridge, Tennessee. 
Vannote, R. L., G. W. Minshall, K. W. Cumnins, J. R. Sedell, and C. E. Cushing. 1980. The river continuum concept. Can. J. Fish. Aquat. Sci. $37: 130-137$.

Van Winkle, W., R. W. Counts, J. G. Dorsey, J. W. Elwood, V. W. Lowe, Jr., R. McElhaney, S. D. Schlotzhauer, F. G. Taylor, Jr., and R. R. Turner. 1984. Mercury contamination in East Fork Poplar Creek and Bear Creek. ORNL/TM-8894.

Ward, J. V., and J. A. Stanford, 1983. The intermediate-disturbance hypothesis: An explanation for biotic diversity patterns in lotic ecosystems. pp. 347-356. IN: T. D. Fontaine and S. M. Bartell (eds.), Dynamics of Lotic Ecosystems. Ann Arbor Science, Ann Arbor, Michigan.

Weber, C. I. (ed.). 1973. Biological field and laboratory methods for measuring the quality of surface waters and effluents. EPA 670/473-001. National Environmental Research Center, U.S. Environmental Protection Agency, Cincinnati.

Wetze1, R. G. 1983. Limnology, 2nd ed. Saunders College Publishing, Inc., Fhiladelphia.

White, R. K., J. Shireman, G. R. Southworth, F. R. O'Donnell, D. A. White, and C. C. Travis, 1989. Analysis of proposed postclosure alternatives at the S-3 ponds at the Y-12 Plant, Oak Ridge, Tennessee. Y/TS-529. Y-12 Plant, Oak Ridge, Tennessee.

Wiederholm, T. 1984. Responses of aquatic insects to environmental pollution. pp. 508-557. IN: V. H. Resh and D. M. Rosenberg (eds.), The Ecology of Aquatic Insects. Praeger Publishers, New York.

Williams, D. D. 1987. The Ecology of Temporary Waters. Timber Press, Portland, Oregon.

Winner, R. W., M. W. Boesel, and M. P. Farrel1. 1980. Insect community structure as an index of heavy-metal pollution in lotic ecosystems. Can. J. Fish. Aquat. Sci, 37:647-655.

Zippin, C. 1956. An evaluation of the removal method of estimating animal populations. Biometrics 12:163-169.

Zippin, C. 1958. The removal method of population estimation. J. Wildl. Manage. 22:82-90. 
APPENDIX A

MEAN MONTHLY TEMPERATURES IN BEAR CREEK, SOUTH SPRING 5 , AND GRASSY CREEK, SEPTEMBER 1985--DECEMBER 1987 


$$
\text { A- } 3
$$

Table A-1. Mean ( $\pm S D$ ) monthly water temperatures $\left({ }^{\circ} \mathrm{C}\right.$ ) In Bear Creek (BCK) and South Spring 5 (SS5), September-December 1.985. Absolute minfmum and maximum temperatures are given in parentheses; the number of days of record is also given. Data were obtained at 2 -h intervals using a Ryan-Peabody thermograph (Model $\mathrm{J}-90$ )

\begin{tabular}{|c|c|c|c|c|}
\hline Site & Sep & Oct & Nov & Dec \\
\hline BCK 9.91 & $\begin{array}{c}17.3 \pm 2.4 \\
(12.2-22.0) \\
30\end{array}$ & $\begin{array}{c}15.8 \pm 1.8 \\
(10.2-18.8) \\
31\end{array}$ & $\begin{array}{c}13.4 \pm 2.3 \\
(7.2-17.2) \\
28\end{array}$ & $\begin{array}{c}6.2 \pm 2.6 \\
(4.0-14.6) \\
31\end{array}$ \\
\hline SS 5 & $\begin{array}{c}13.3 \pm 0.10 \\
(13.0-13.4) \\
30\end{array}$ & $\begin{array}{c}13.2 \pm 0.07 \\
(13.0-13.2) \\
31\end{array}$ & $\begin{array}{c}13.2 \pm 0.18 \\
(13.0-13.6) \\
2.7\end{array}$ & $\begin{array}{c}13.1 \pm 0.20 \\
(12.6-13,6) \\
31\end{array}$ \\
\hline BCK 9.40 & $\begin{array}{c}15.6 \pm 1.4 \\
(13.0-21.0) \\
30\end{array}$ & $\begin{array}{c}14.9 \pm 0.9 \\
(12.2-17.8) \\
31\end{array}$ & $\begin{array}{c}13.7 \pm 1.2 \\
(11.0-16.4) \\
29\end{array}$ & $\begin{array}{c}8.5 \pm 1.9 \\
(4.0-14.4) \\
31\end{array}$ \\
\hline BCK 7.87 & $\begin{array}{c}17.3 \pm 2.3 \\
(11.8-21.6) \\
30\end{array}$ & $\begin{array}{c}15.9 \pm 1.9 \\
(9.6-18.8) \\
31\end{array}$ & $\begin{array}{c}13.1 \pm 2.6 \\
(7.2-17.0) \\
15\end{array}$ & $\begin{array}{c}6.0 \pm 3.3 \\
(1.0-14.8) \\
31\end{array}$ \\
\hline
\end{tabular}




$$
\text { A }-4
$$

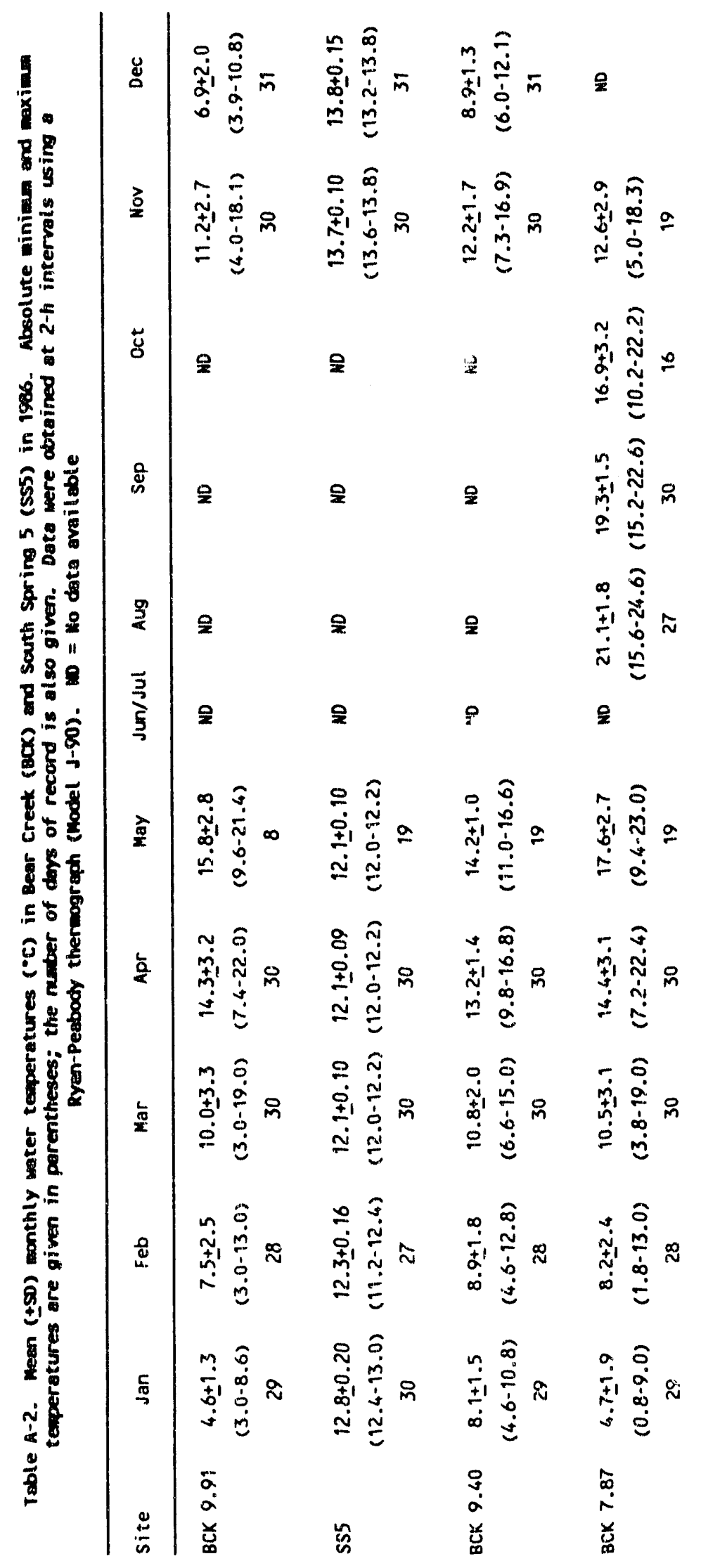




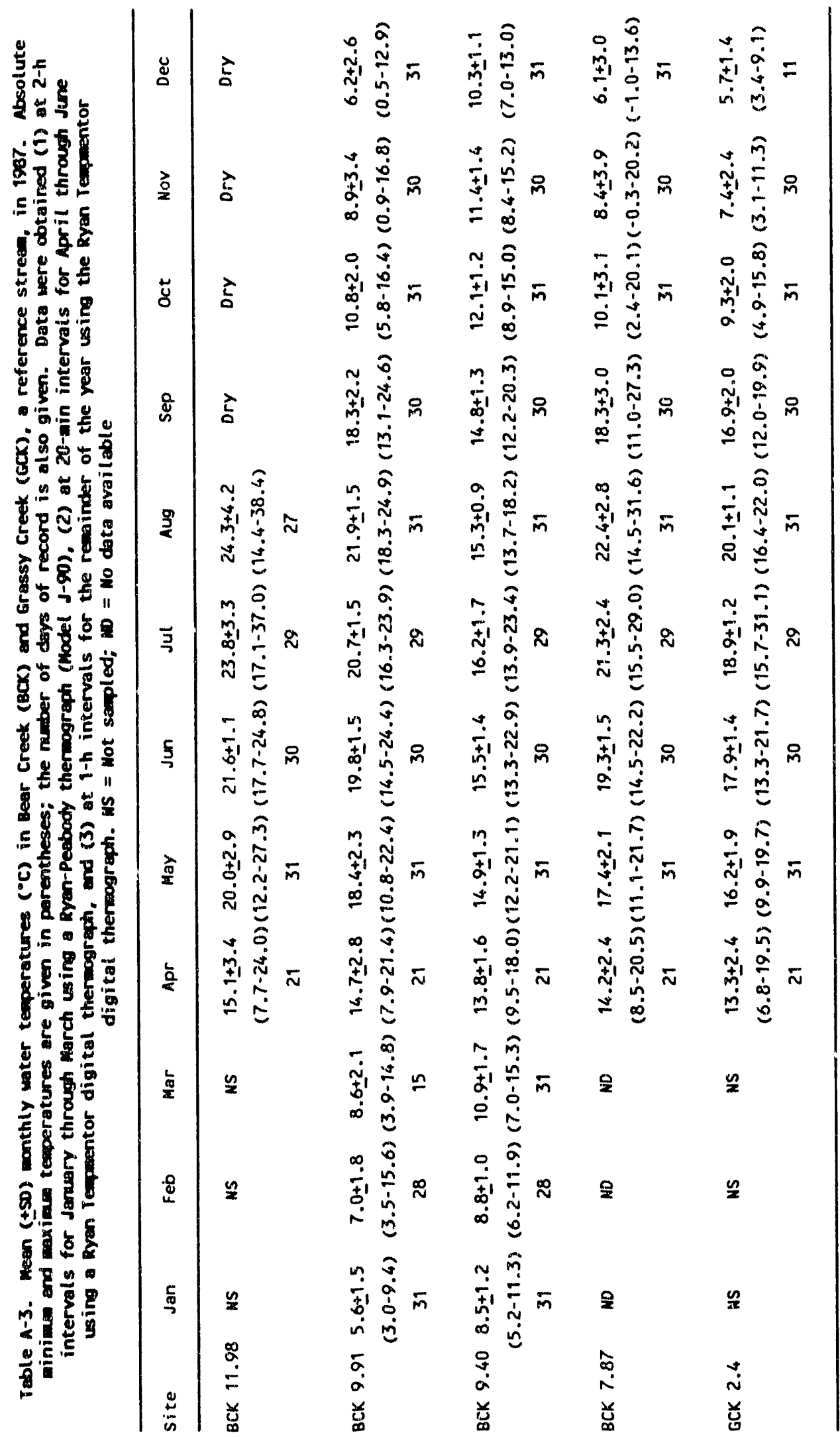




\begin{abstract}
APPENDIX B
DENSITY AND BIOMASS OF FISHES IN BEAR CREEK AND TWO REFERENCE STREAMS, MAY 1984-NOVEMBER 1987
\end{abstract}


B - 3

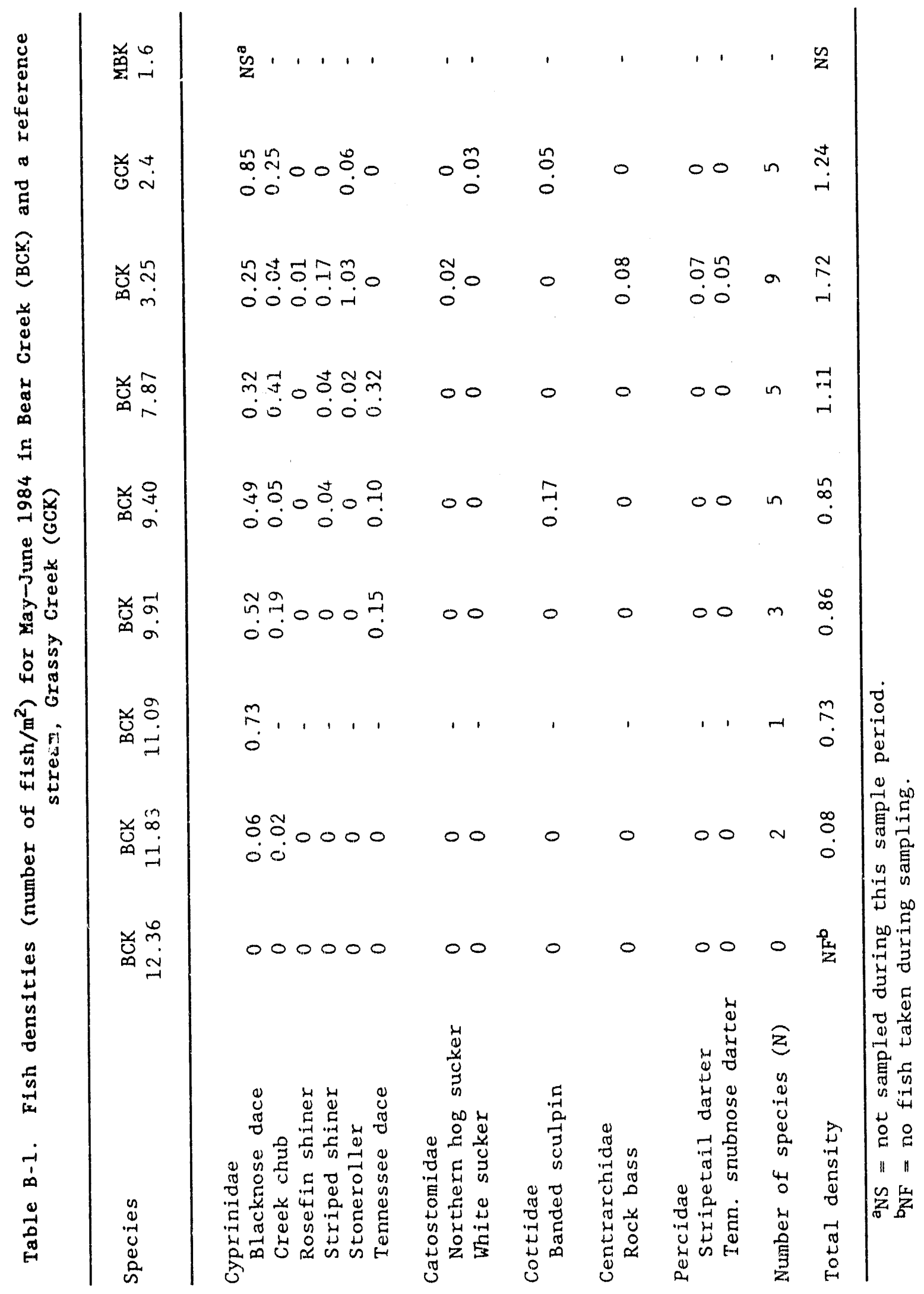




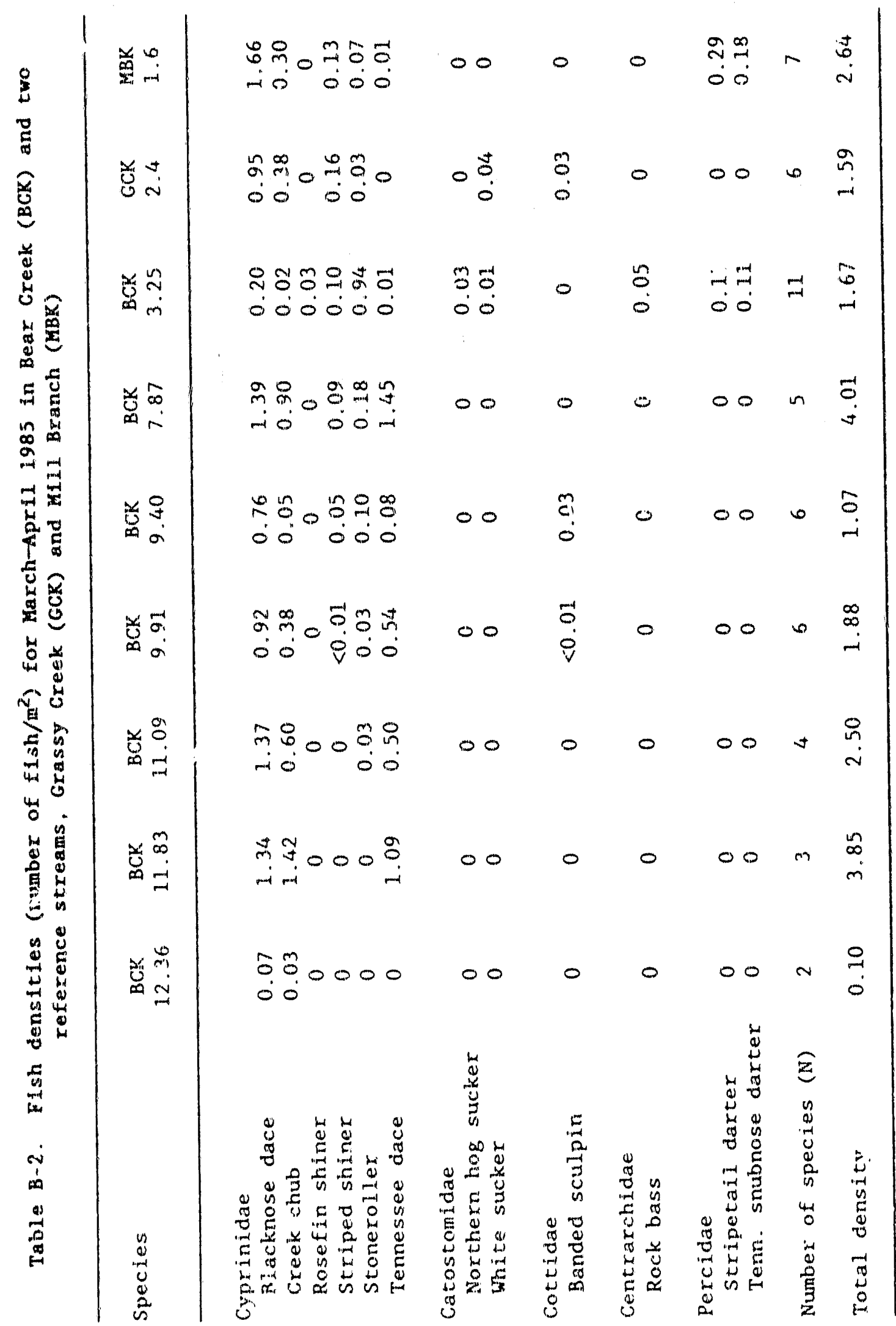




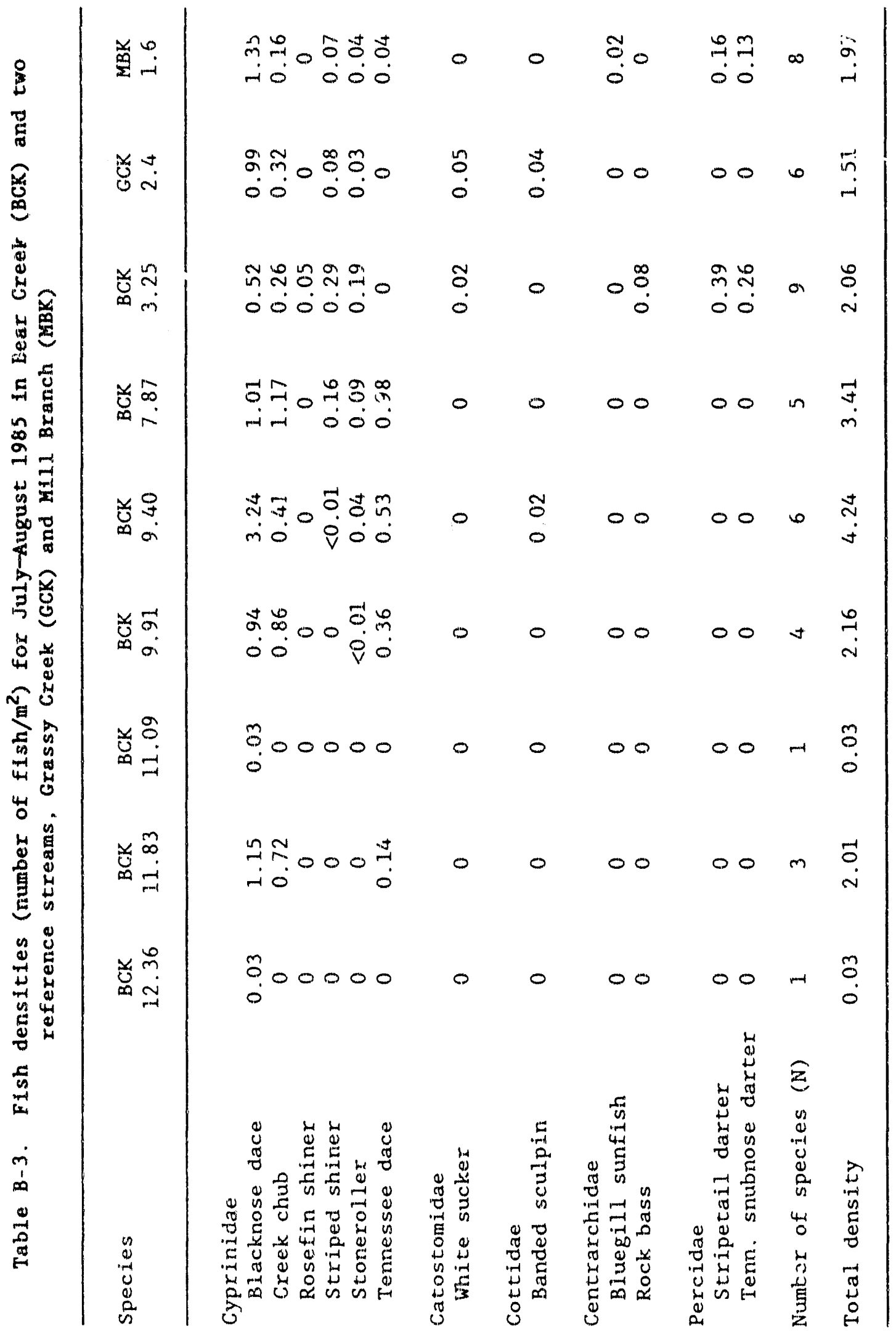




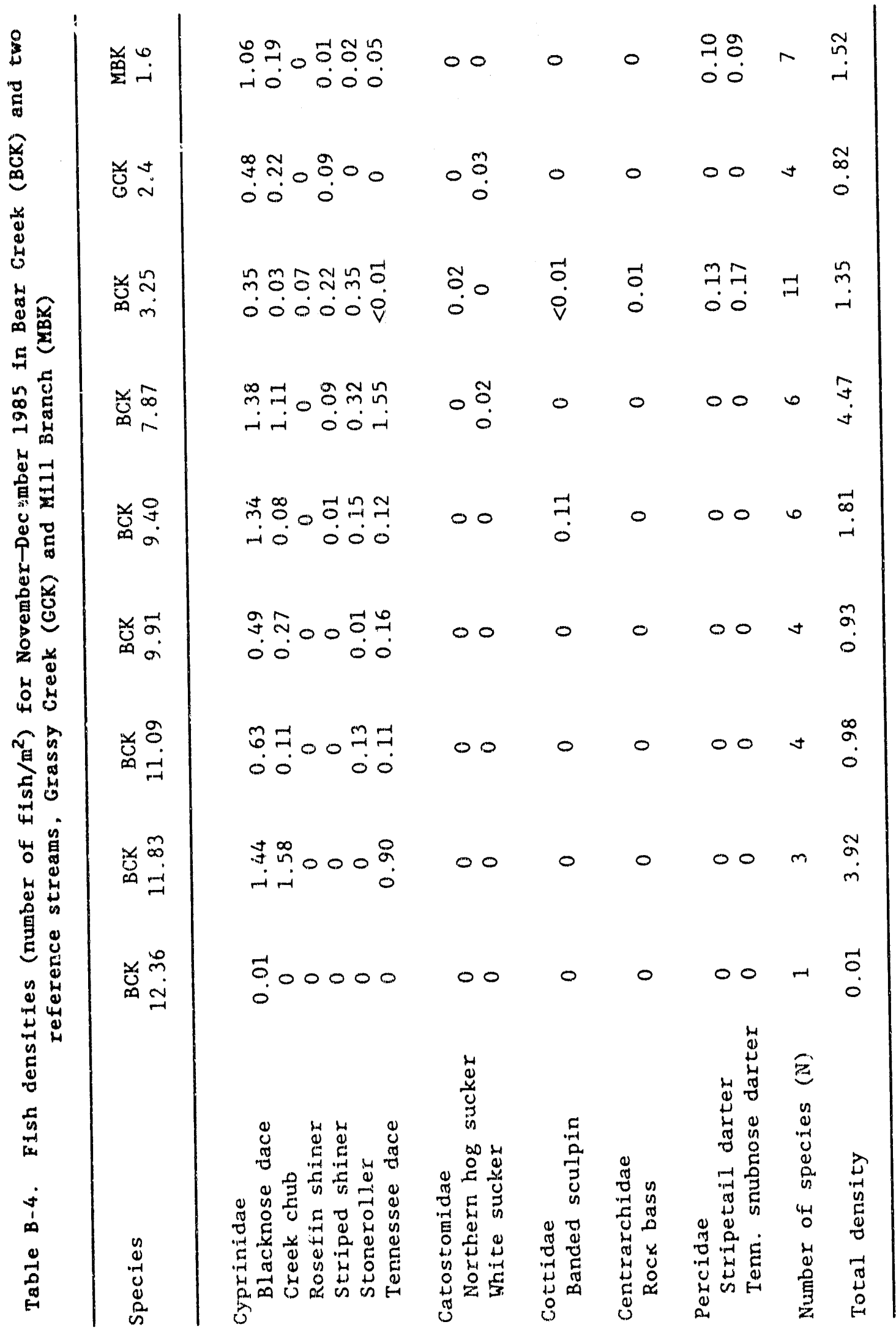




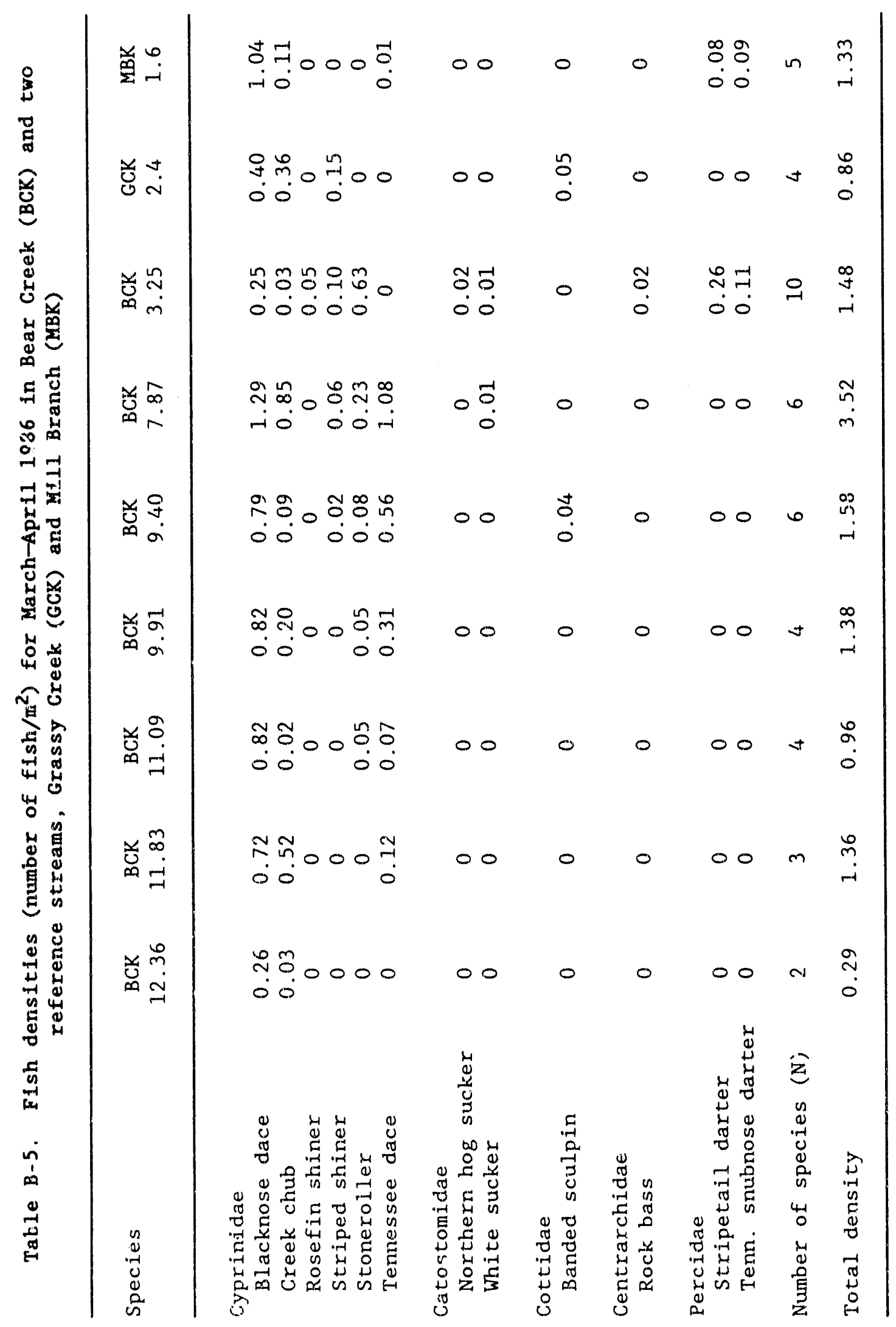




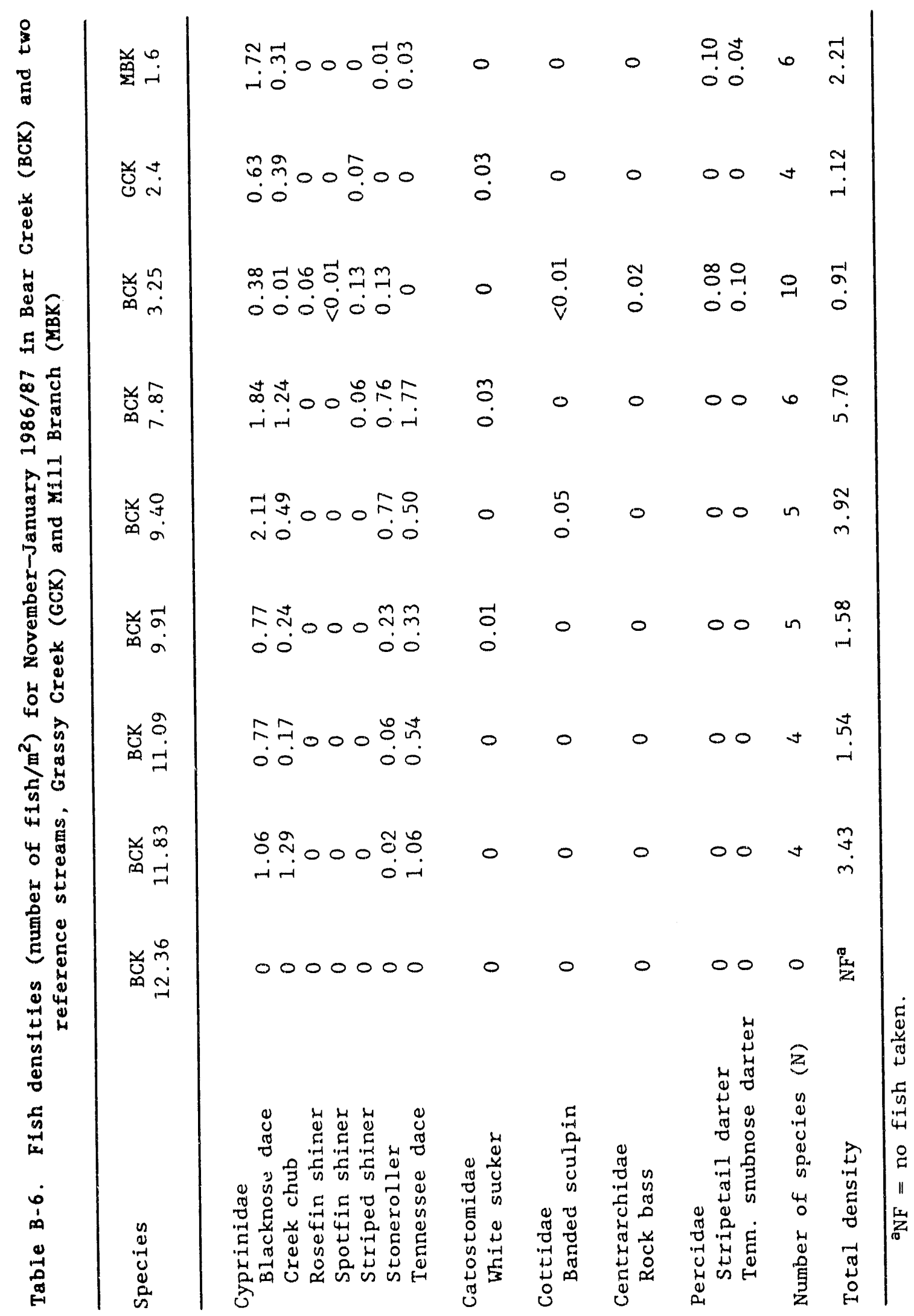




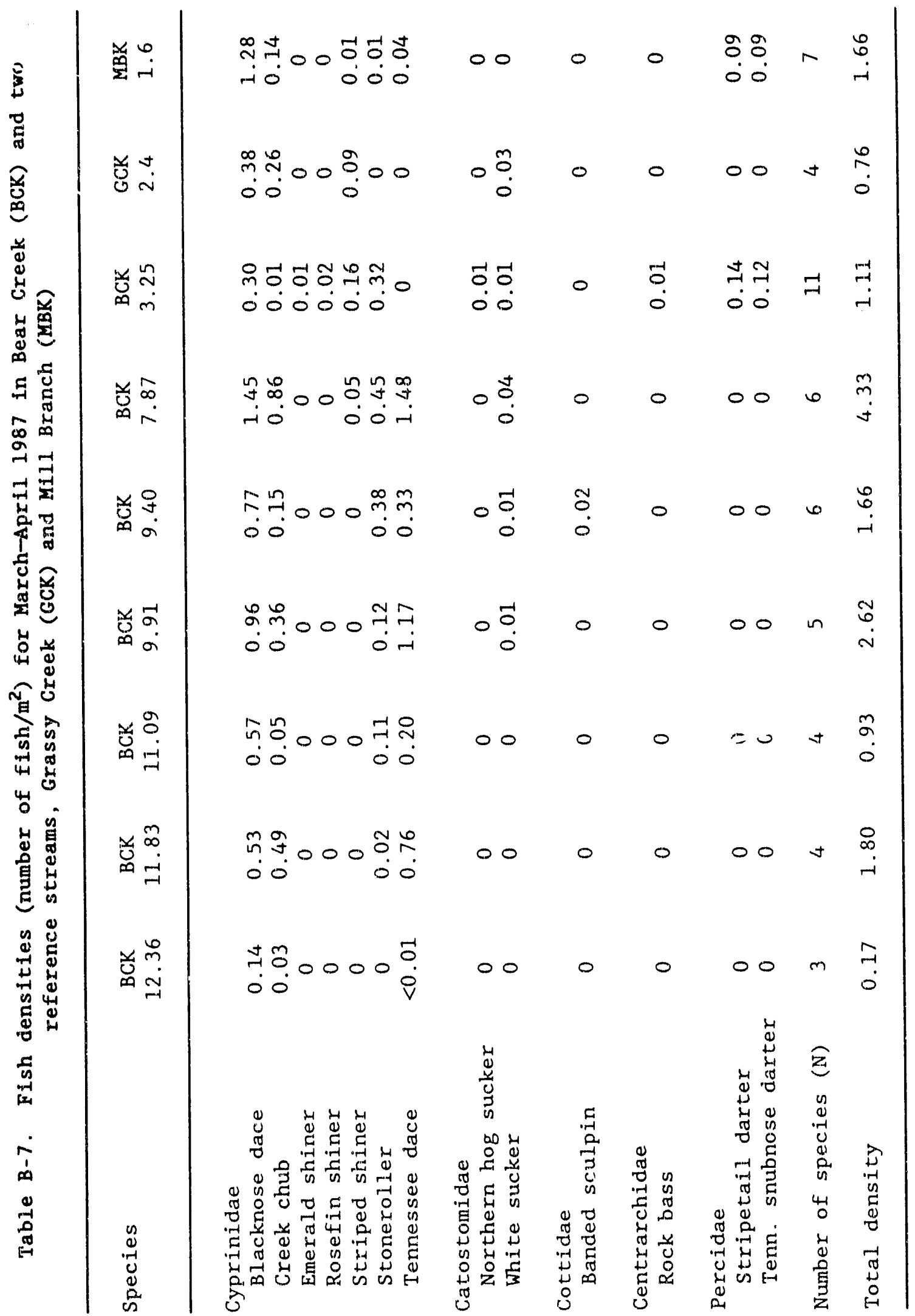




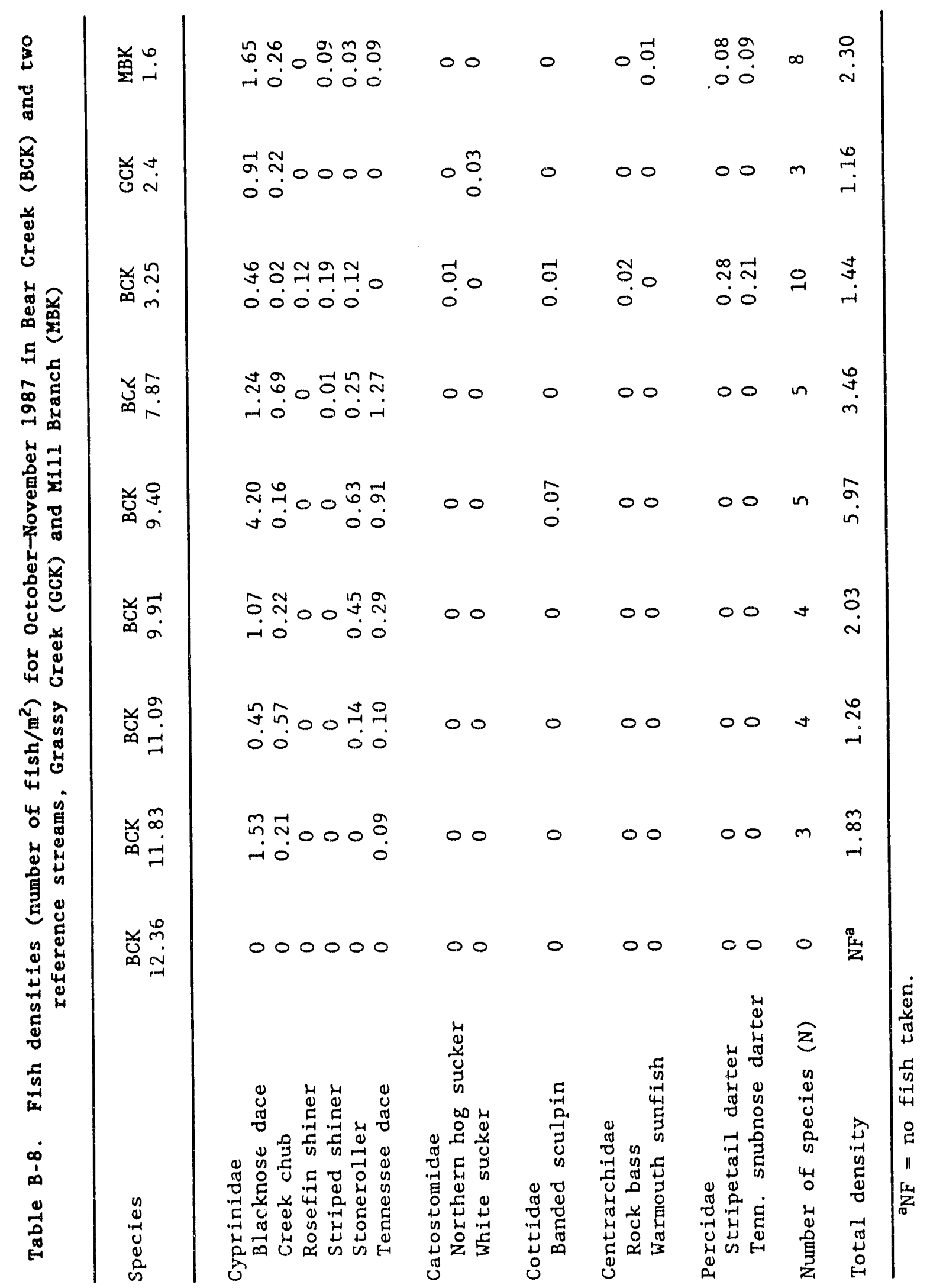




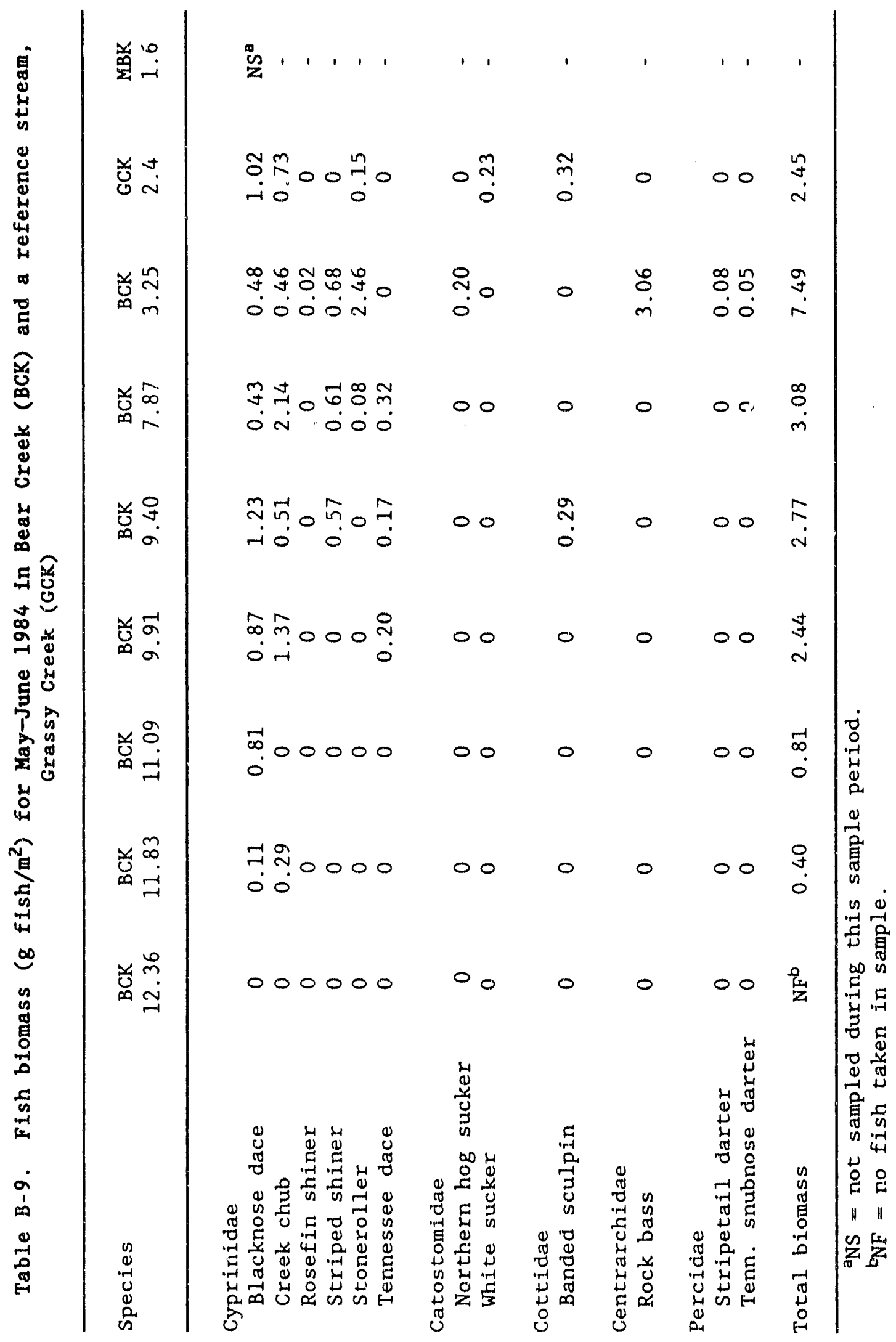




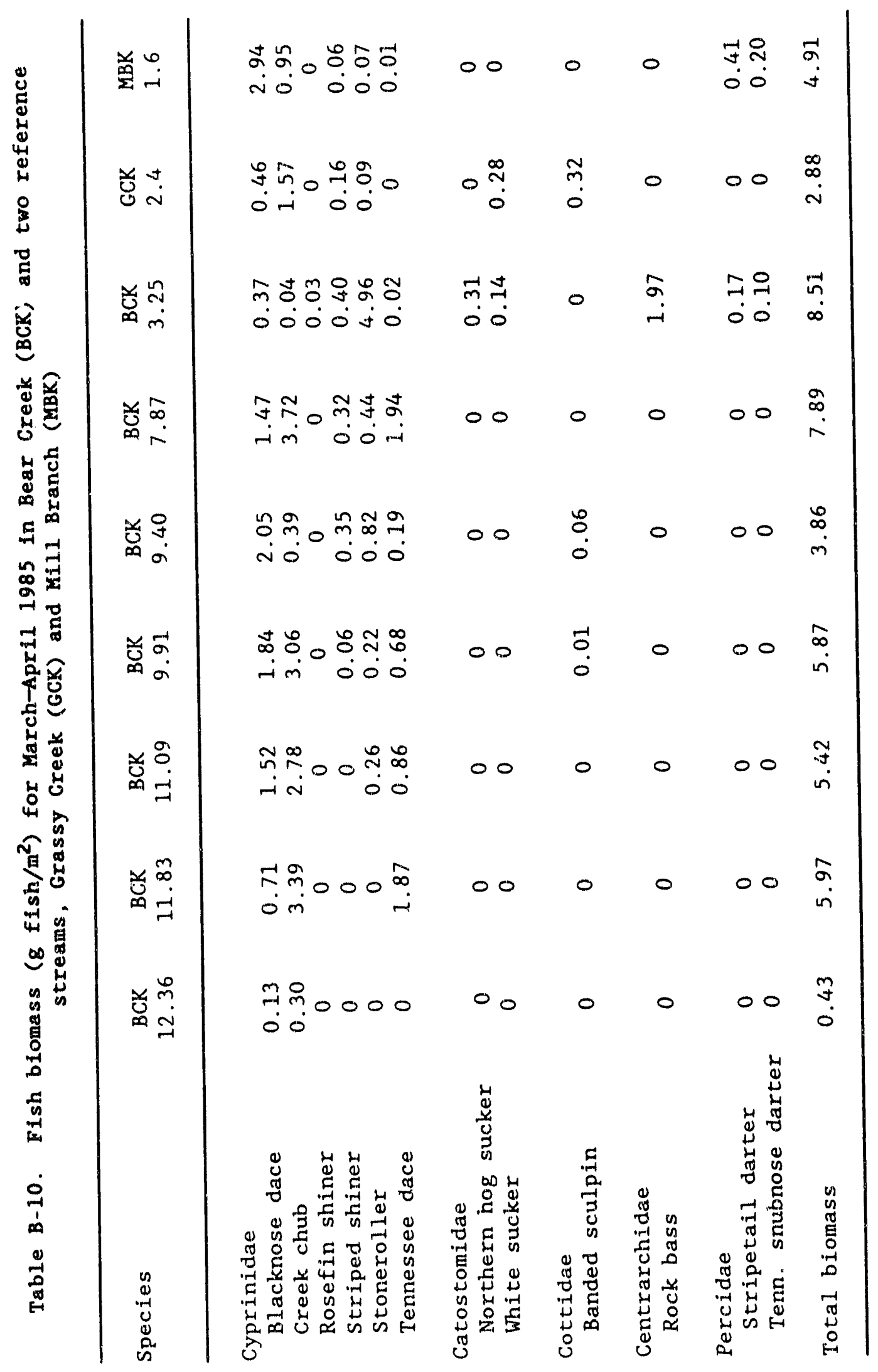


B -13

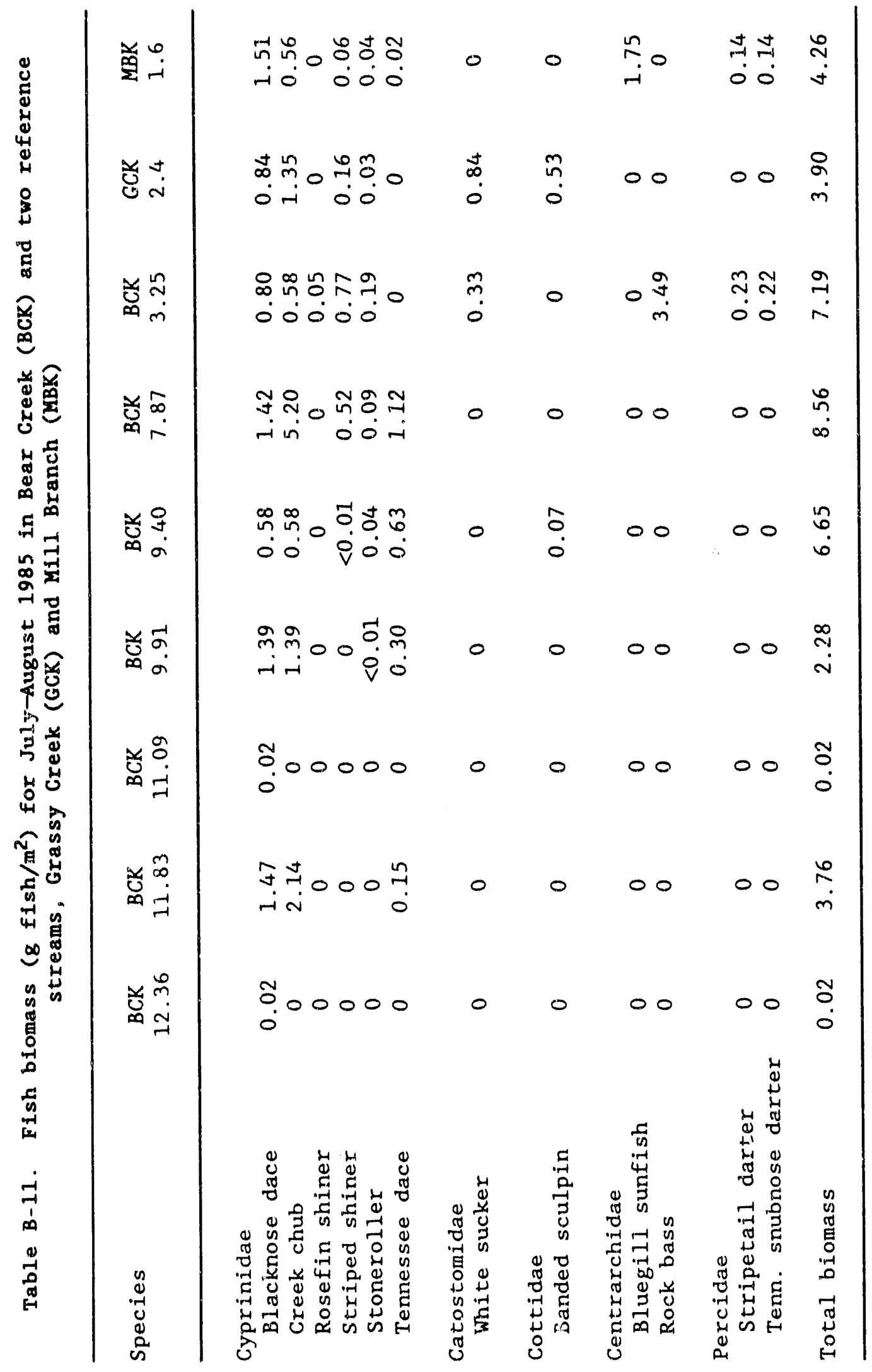




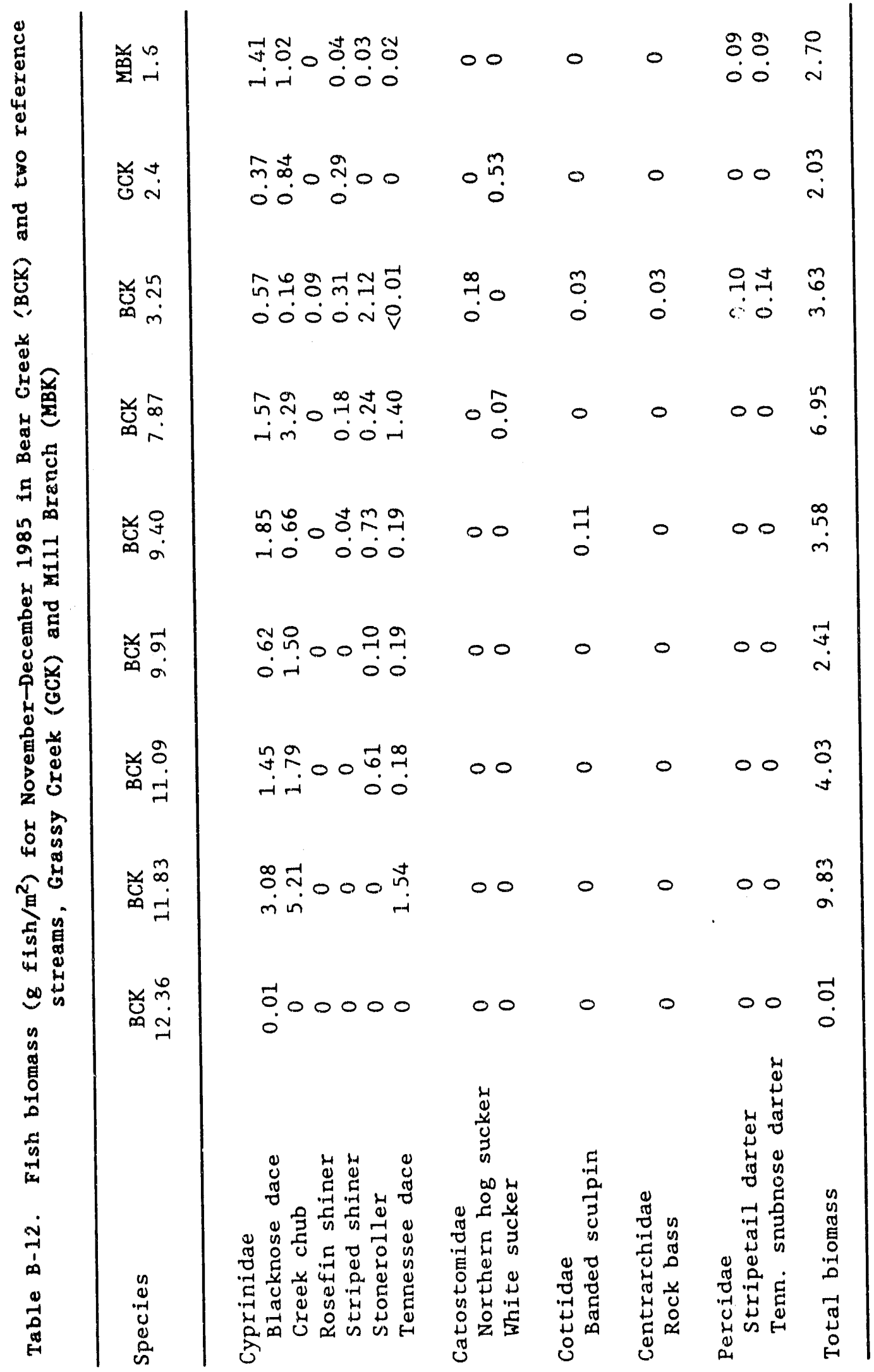




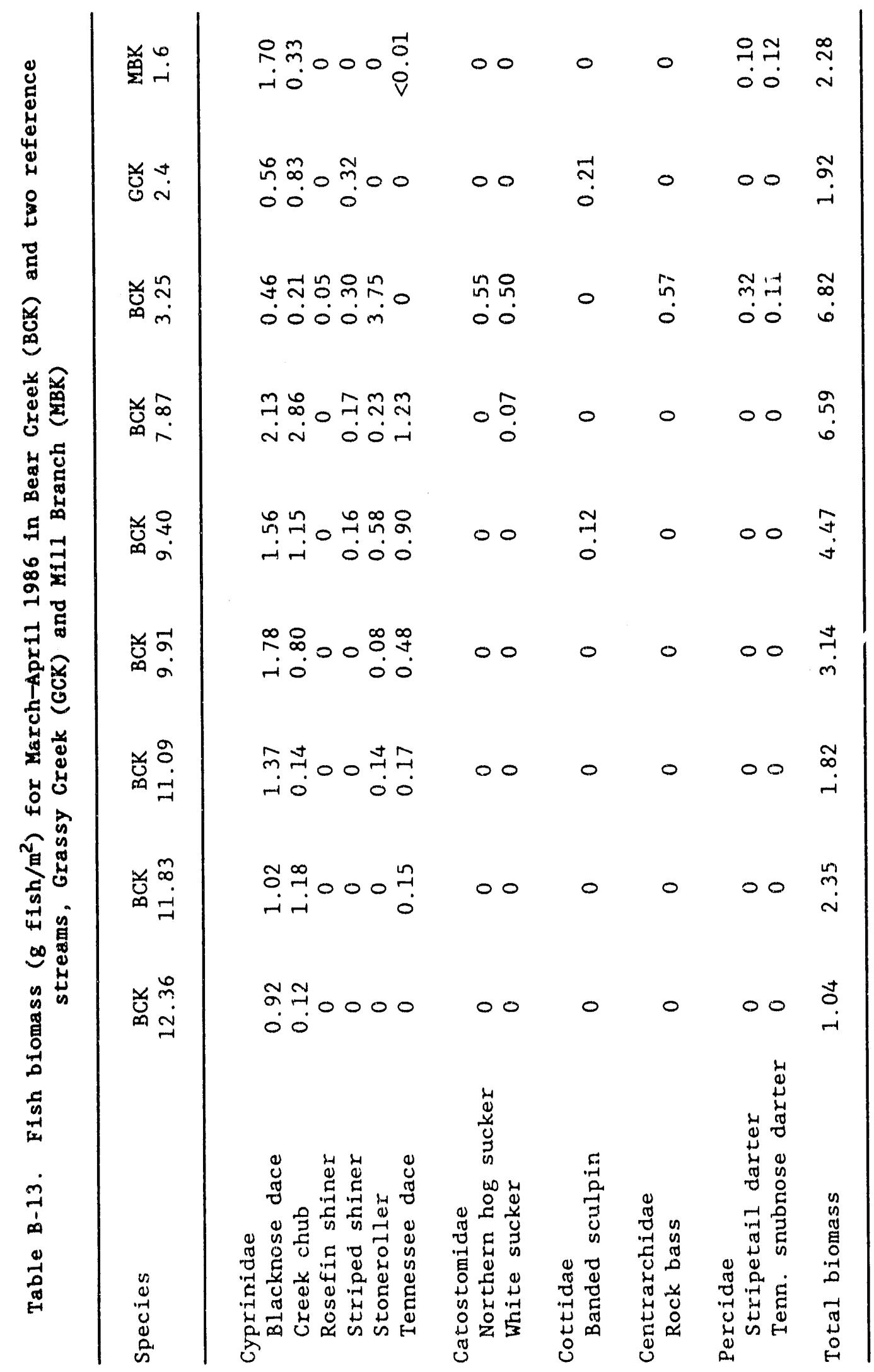




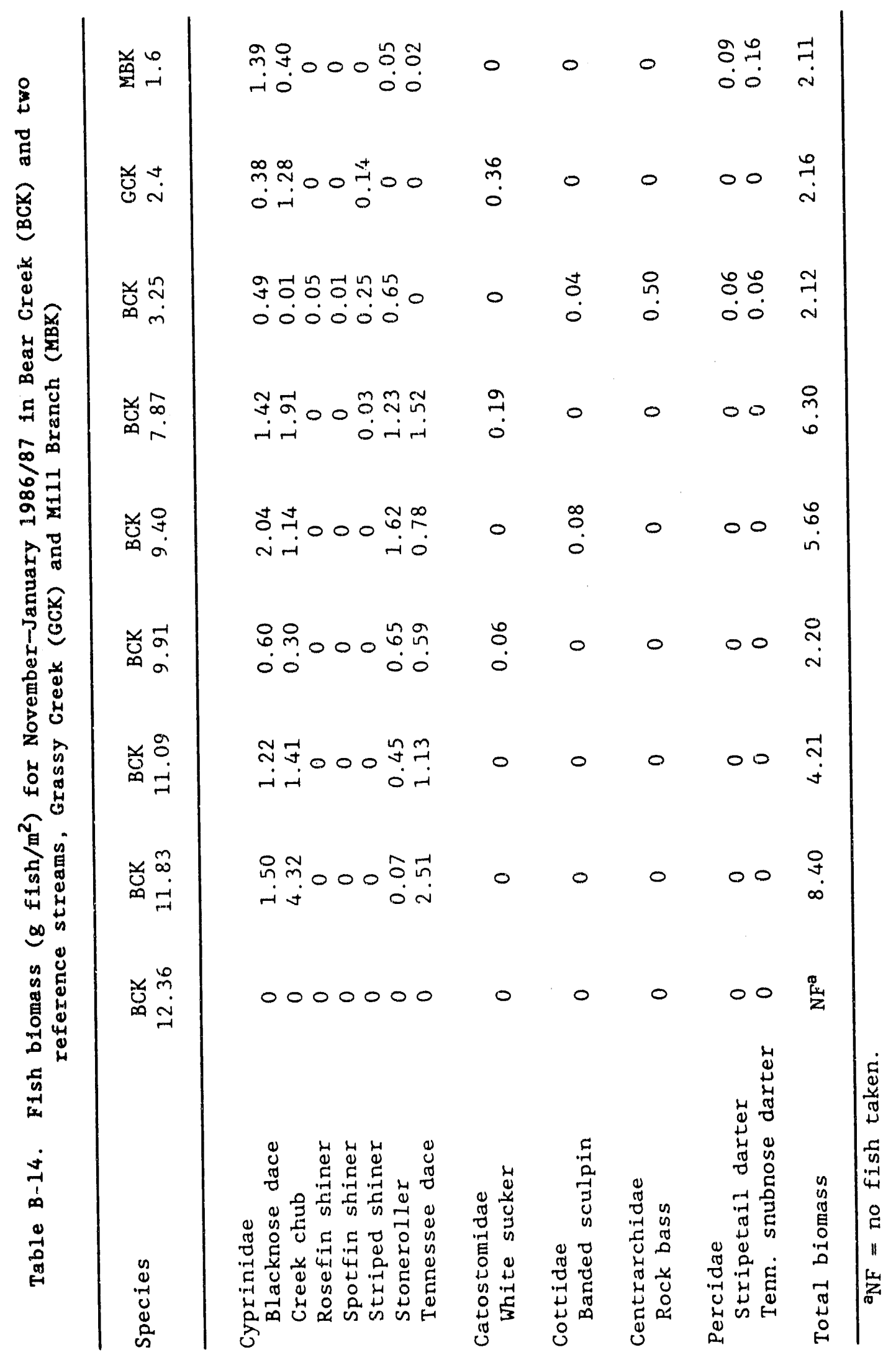




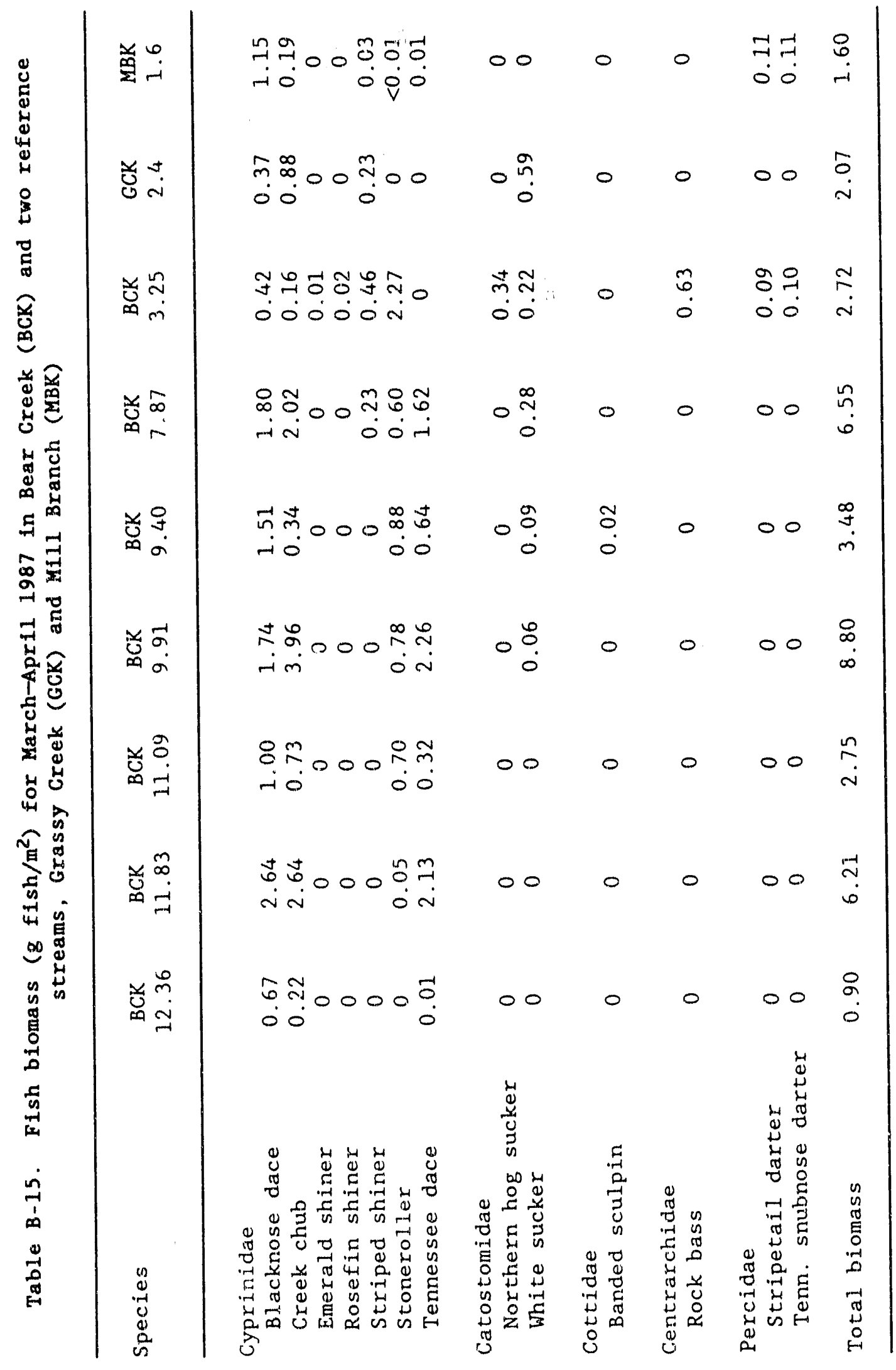




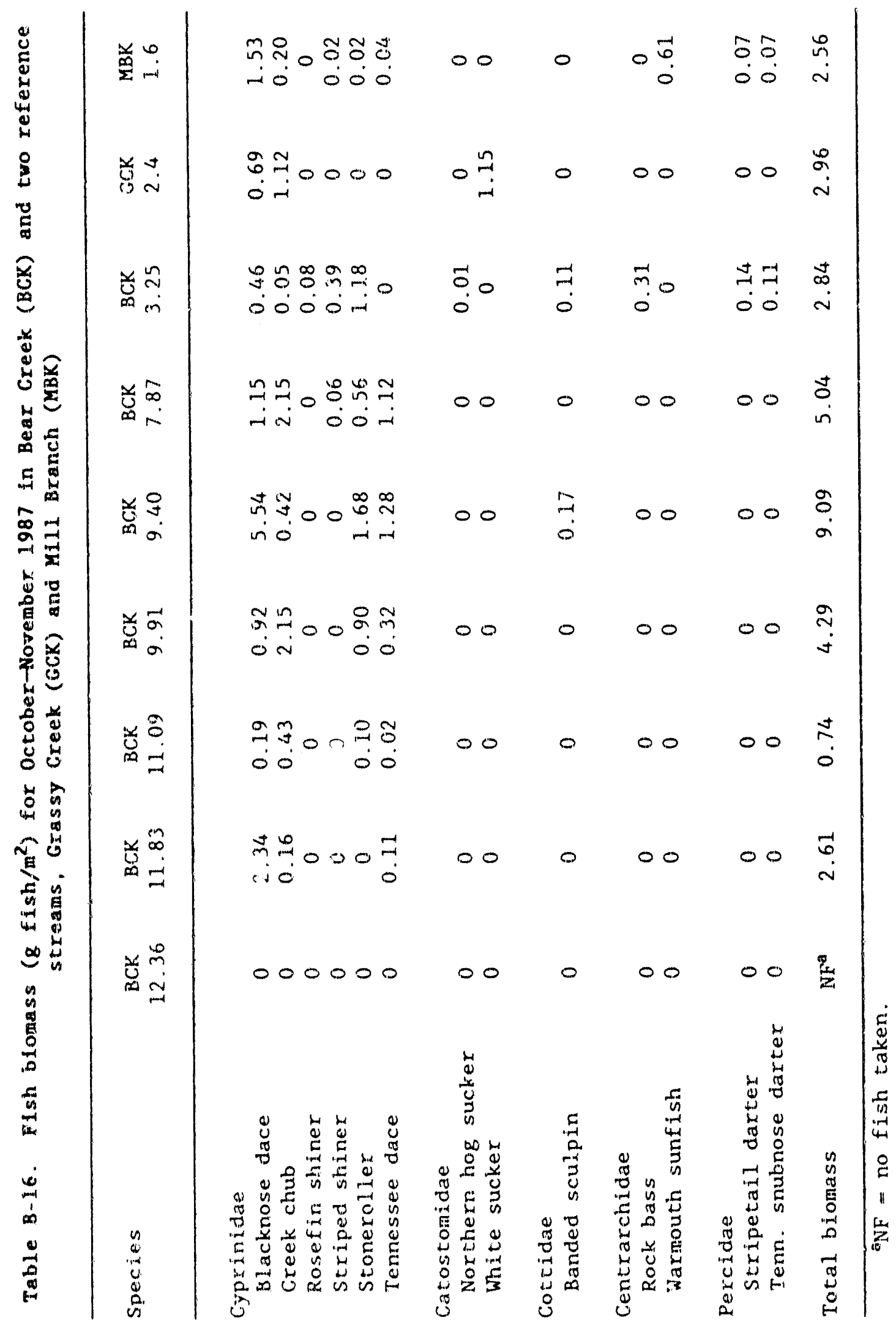


APPENDIX C

STATISTICAL COMPARISON OF FISH CONDITION FACTORS BETWEEN SAMPLING PERIODS AND BETWEEN SAMPLING SITES IN BEAR CREEK AND TWO REFERENCE STREAMS, 1984-1987 
C. 3

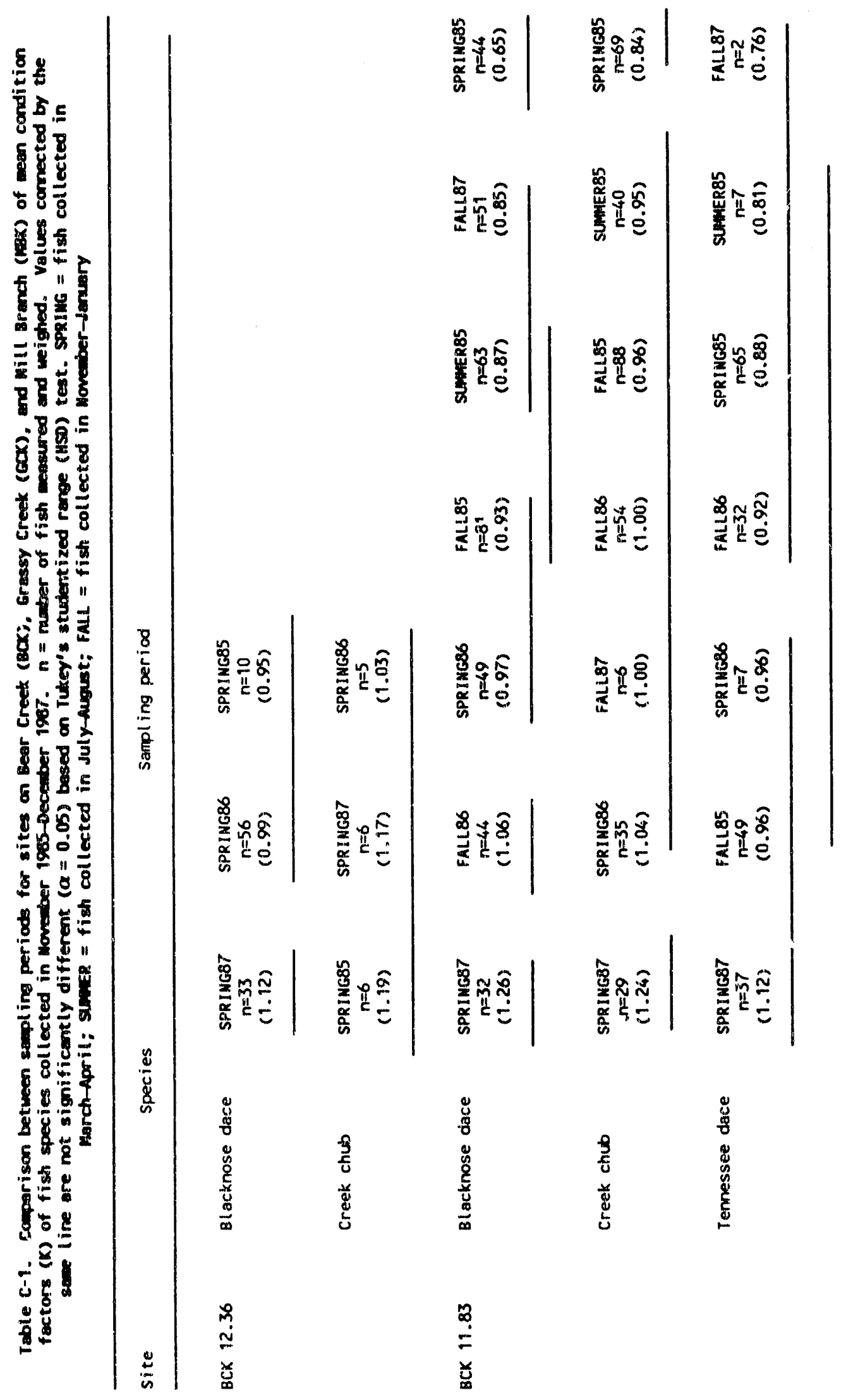




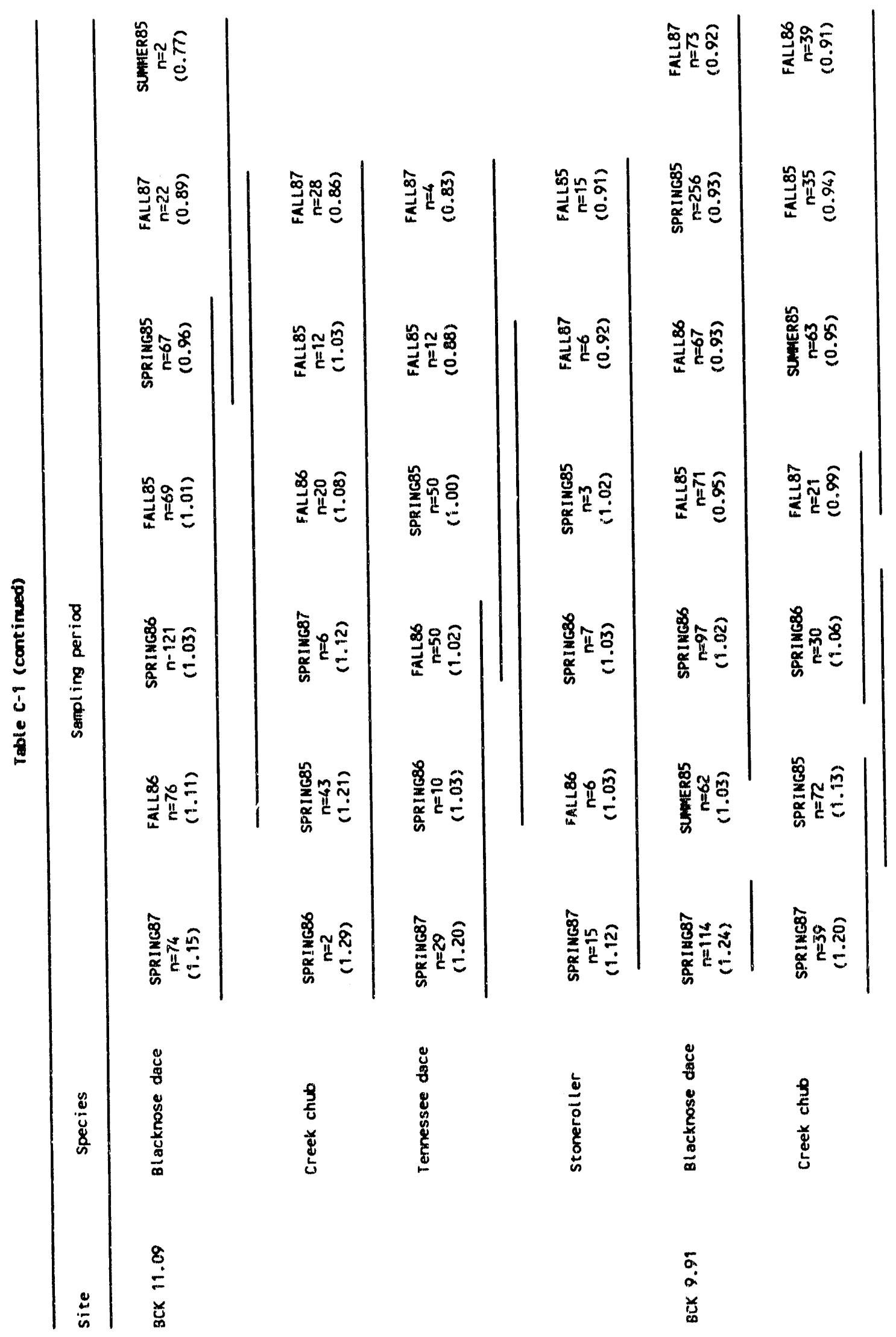


C - 5

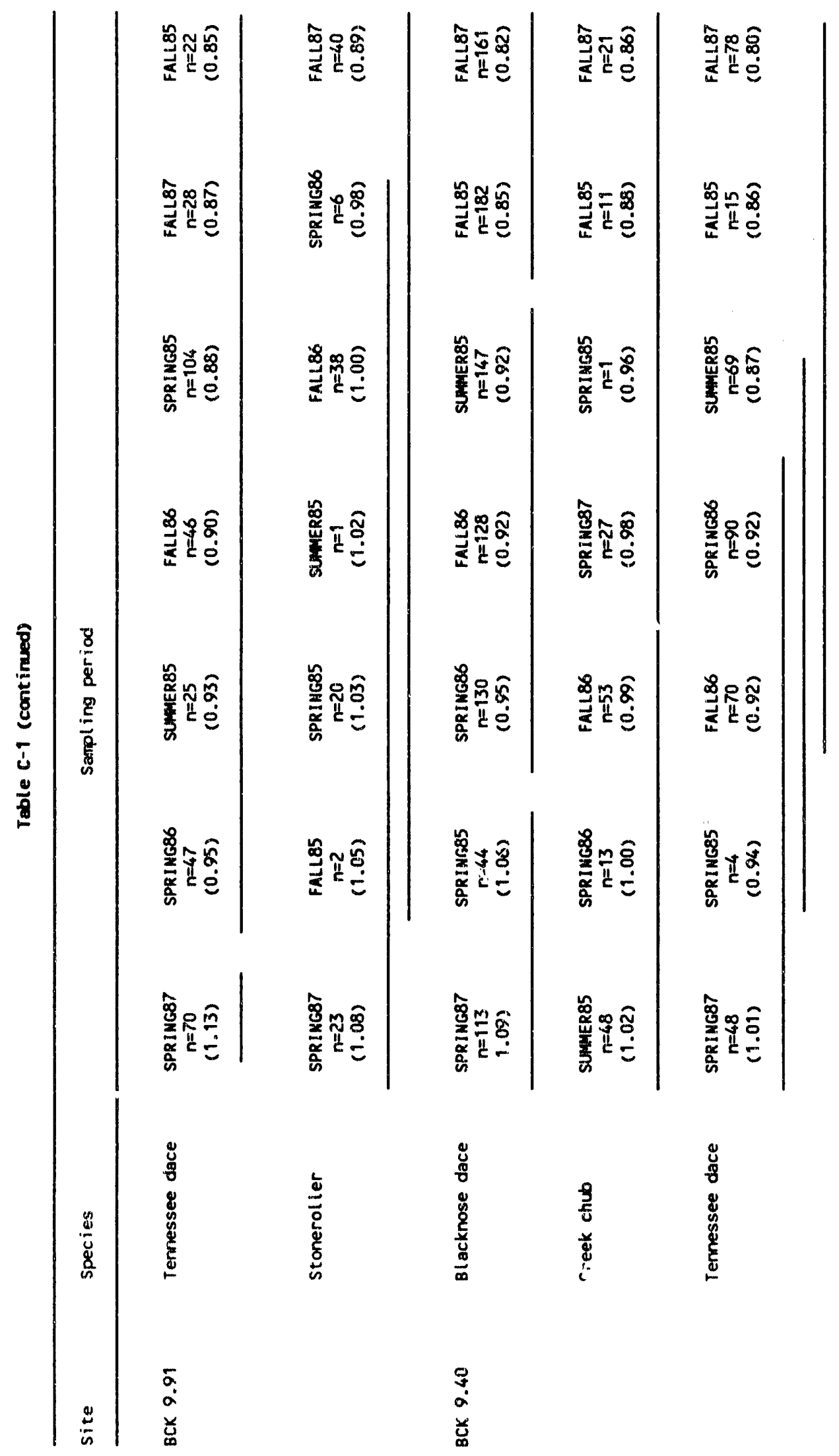


C- 6

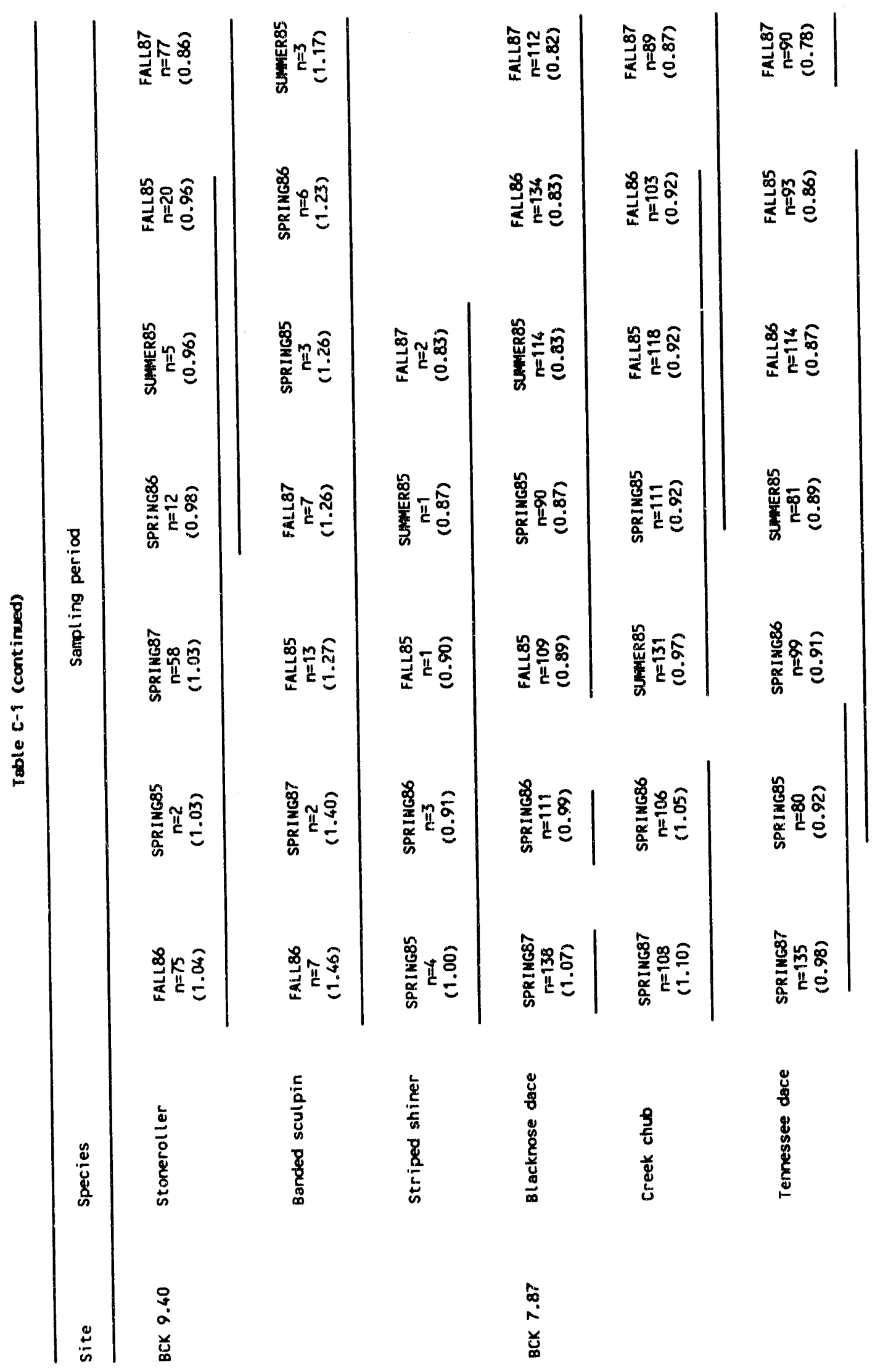




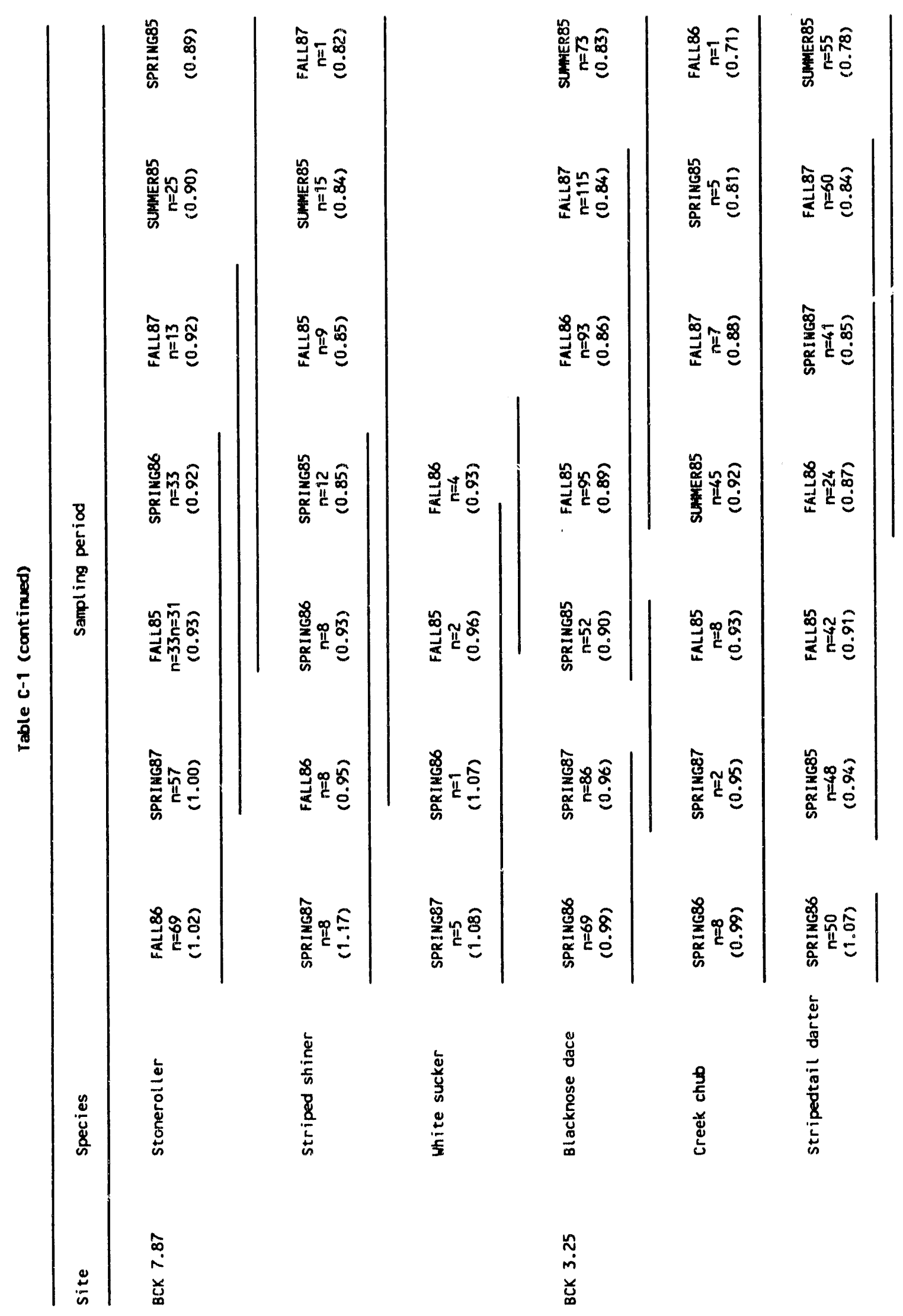




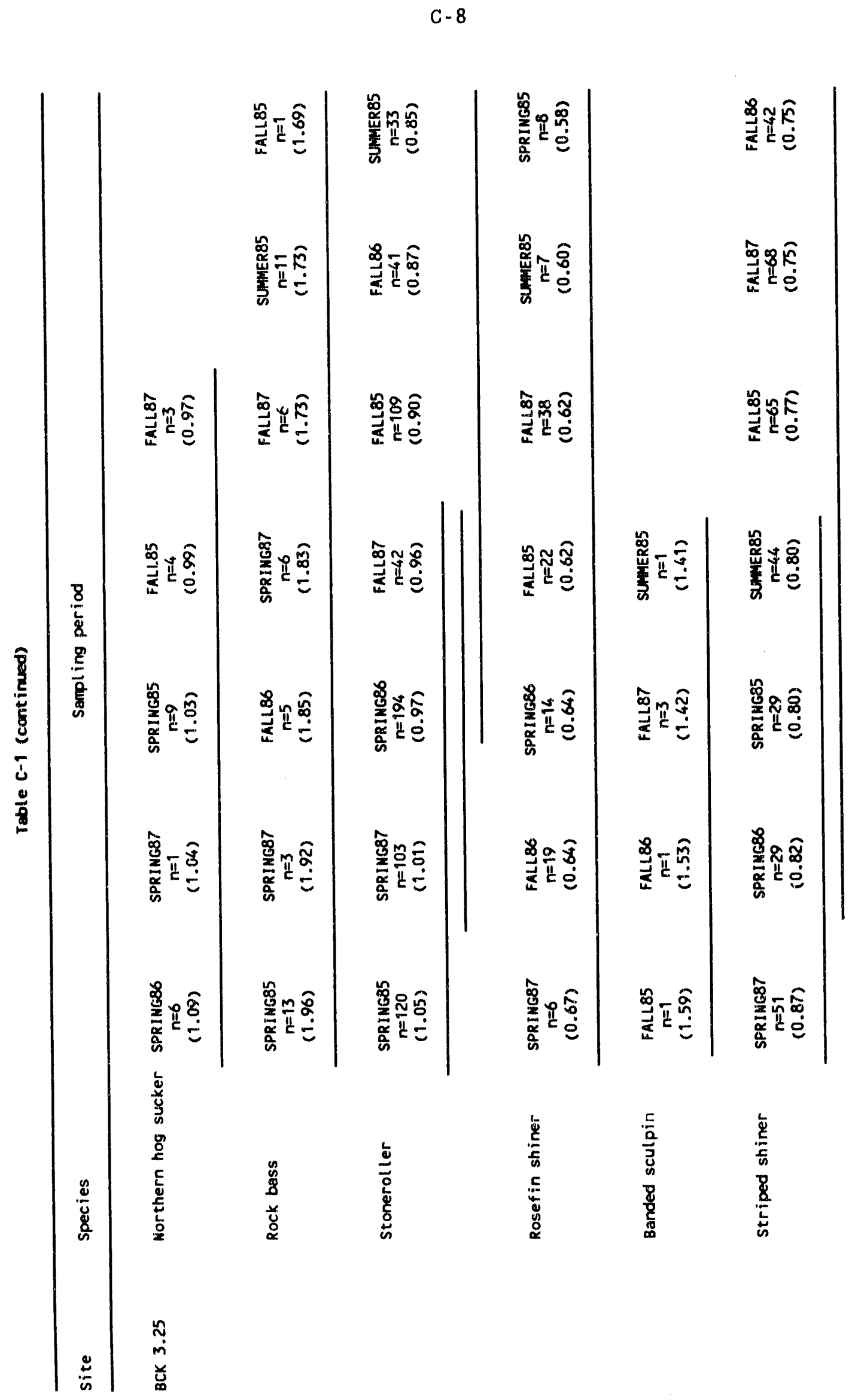




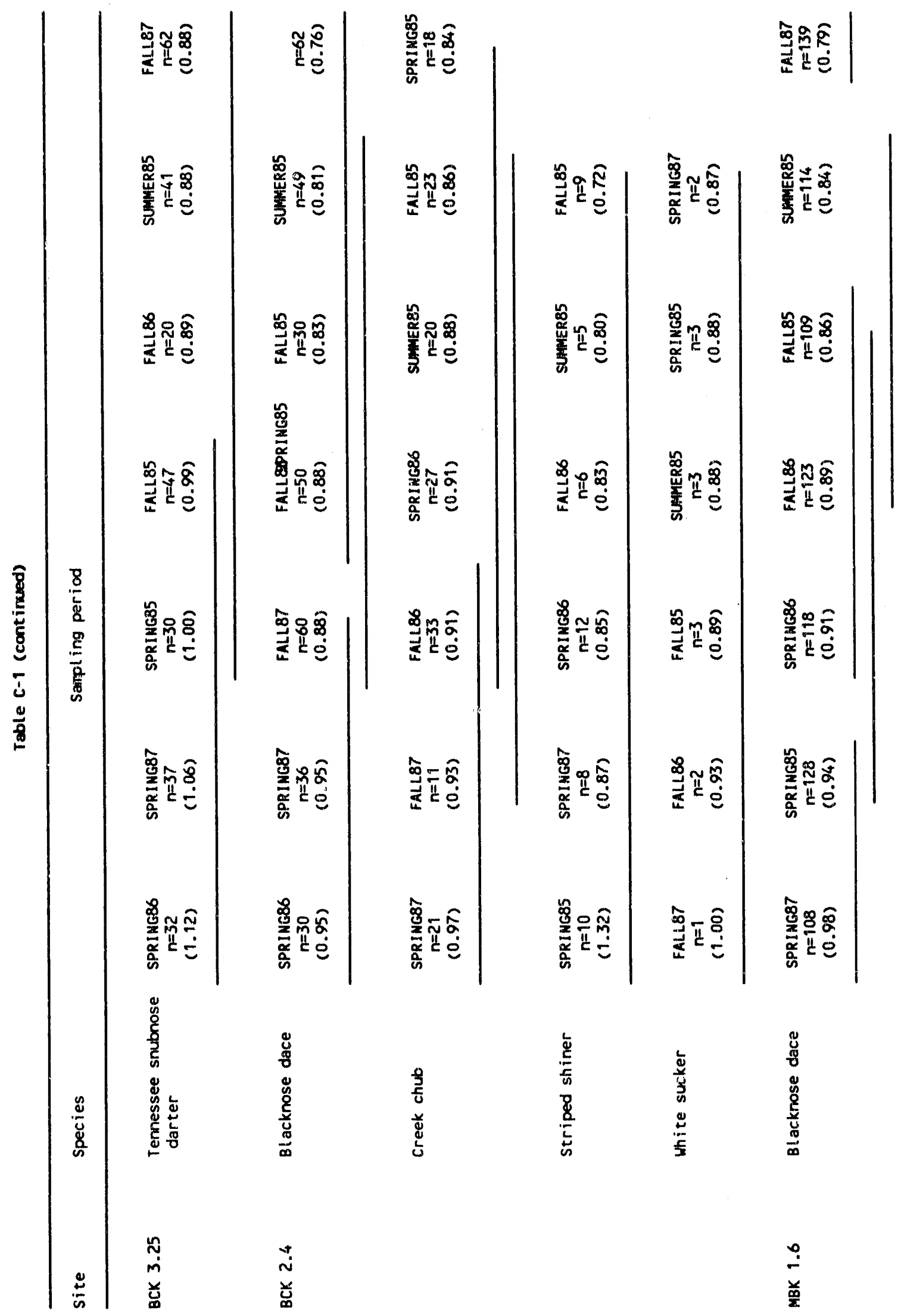


C -10

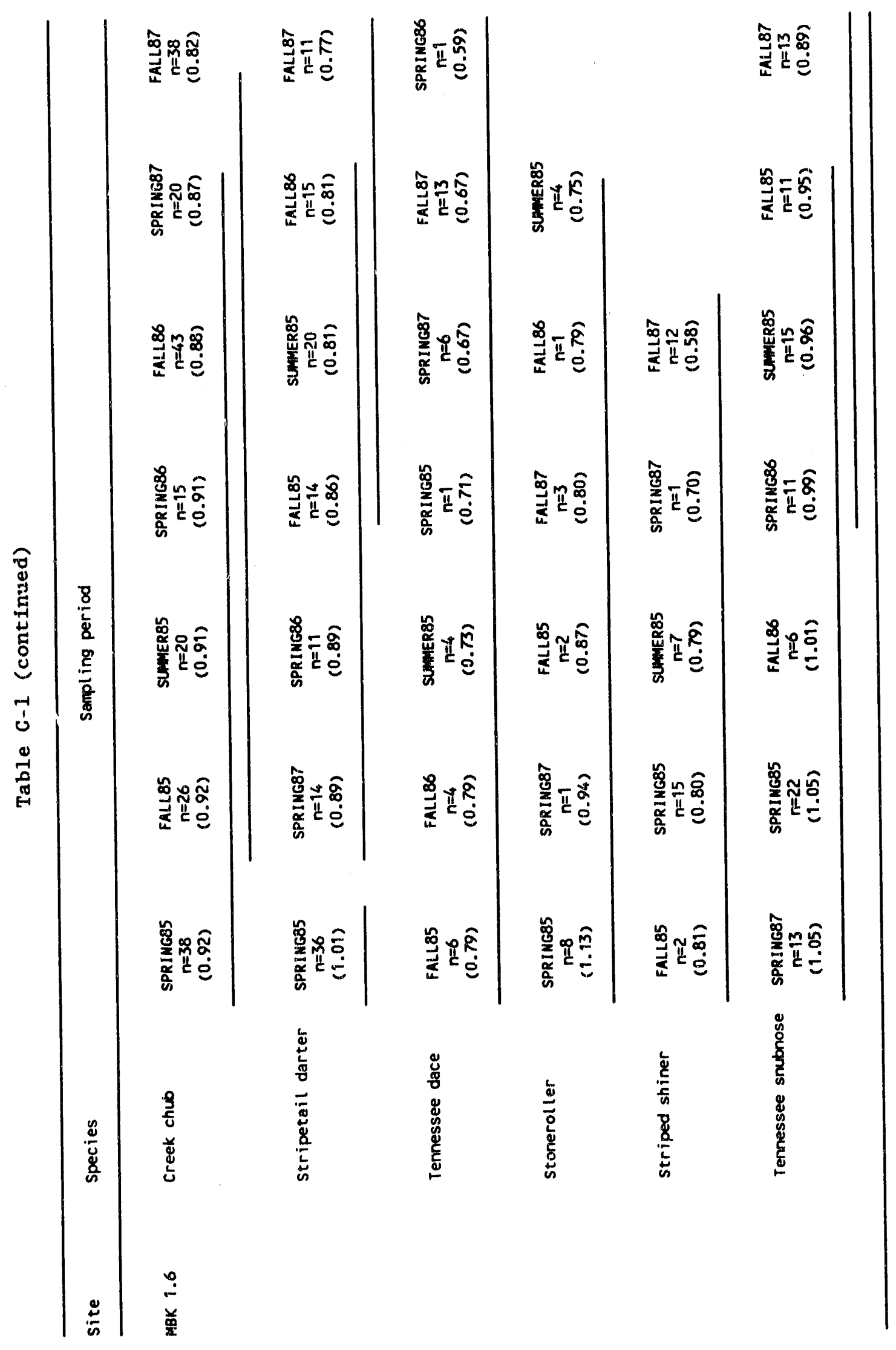




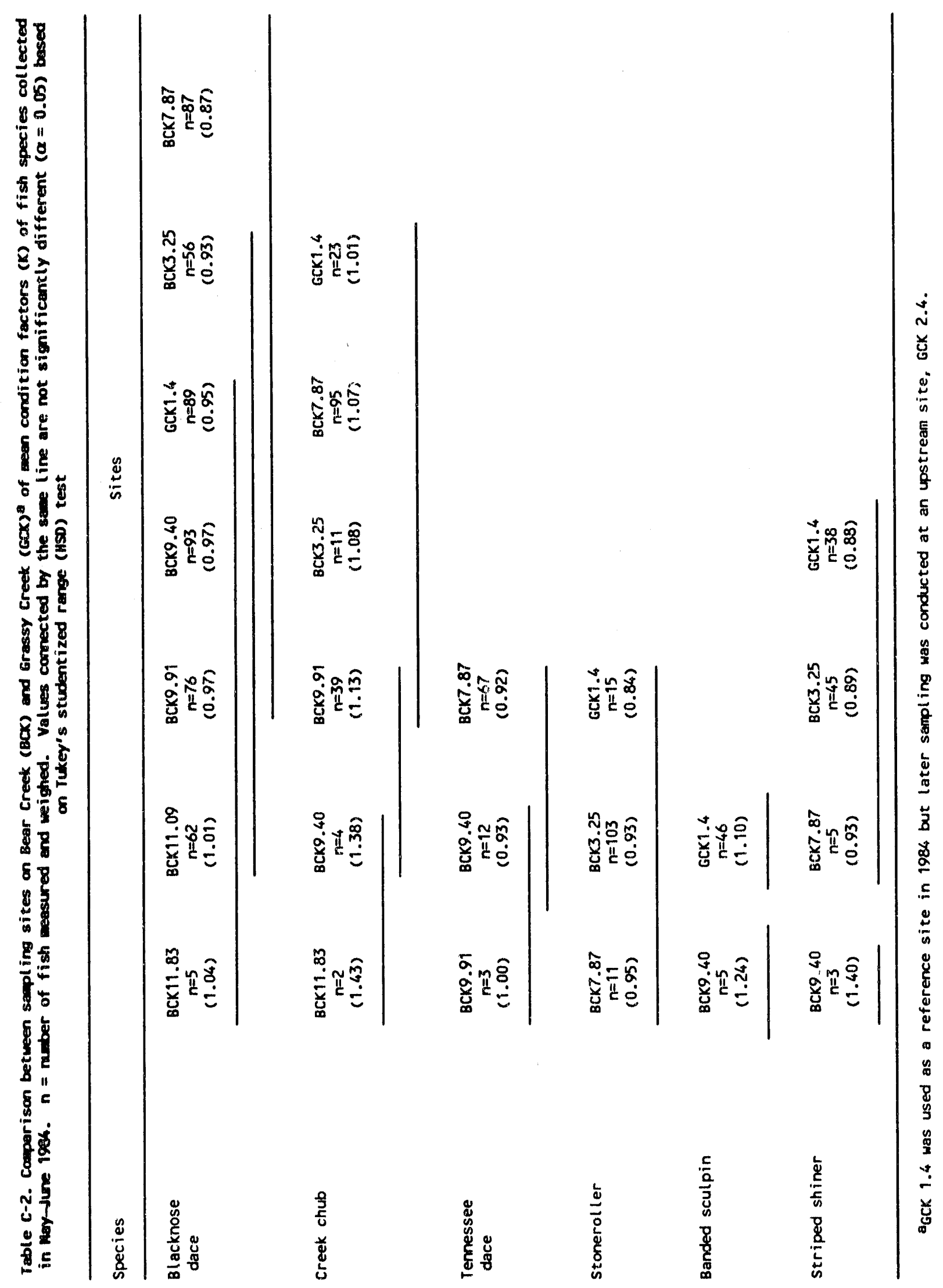




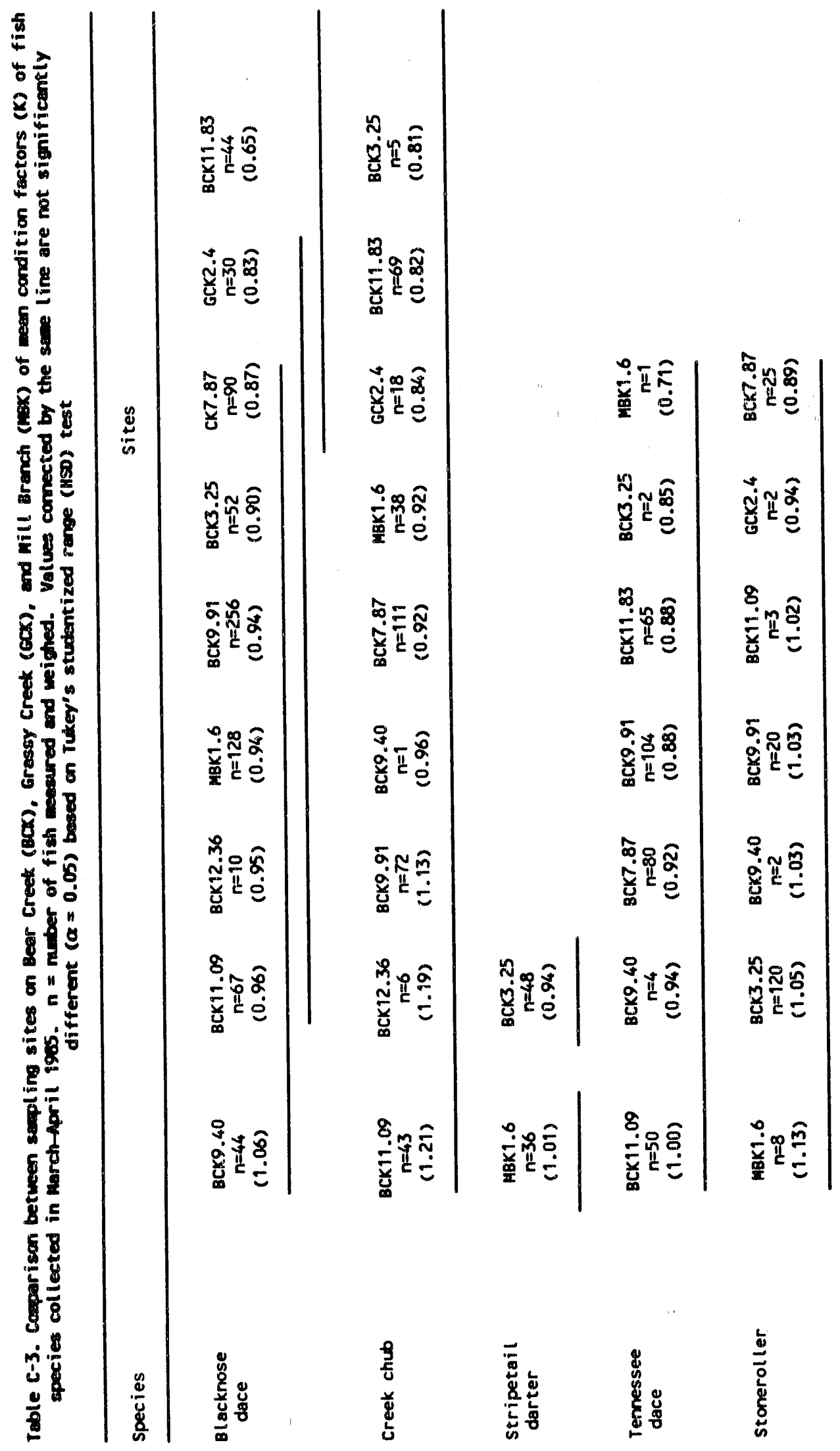




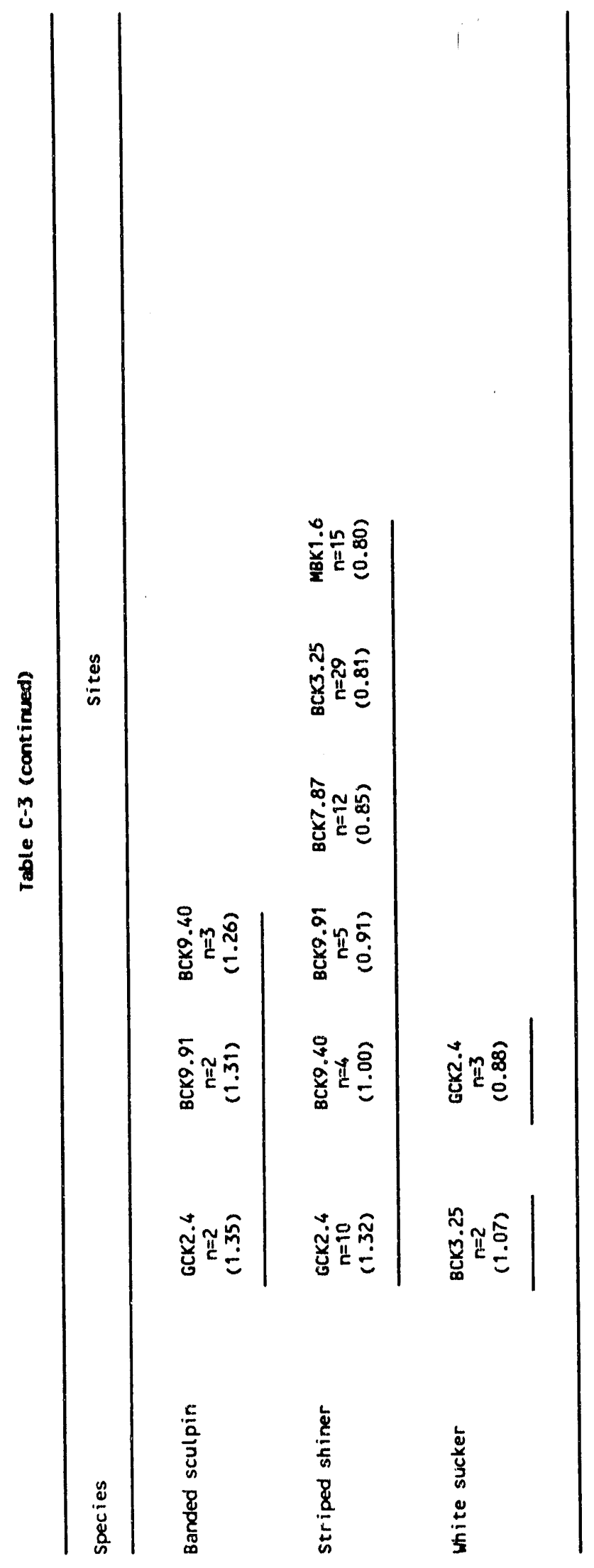




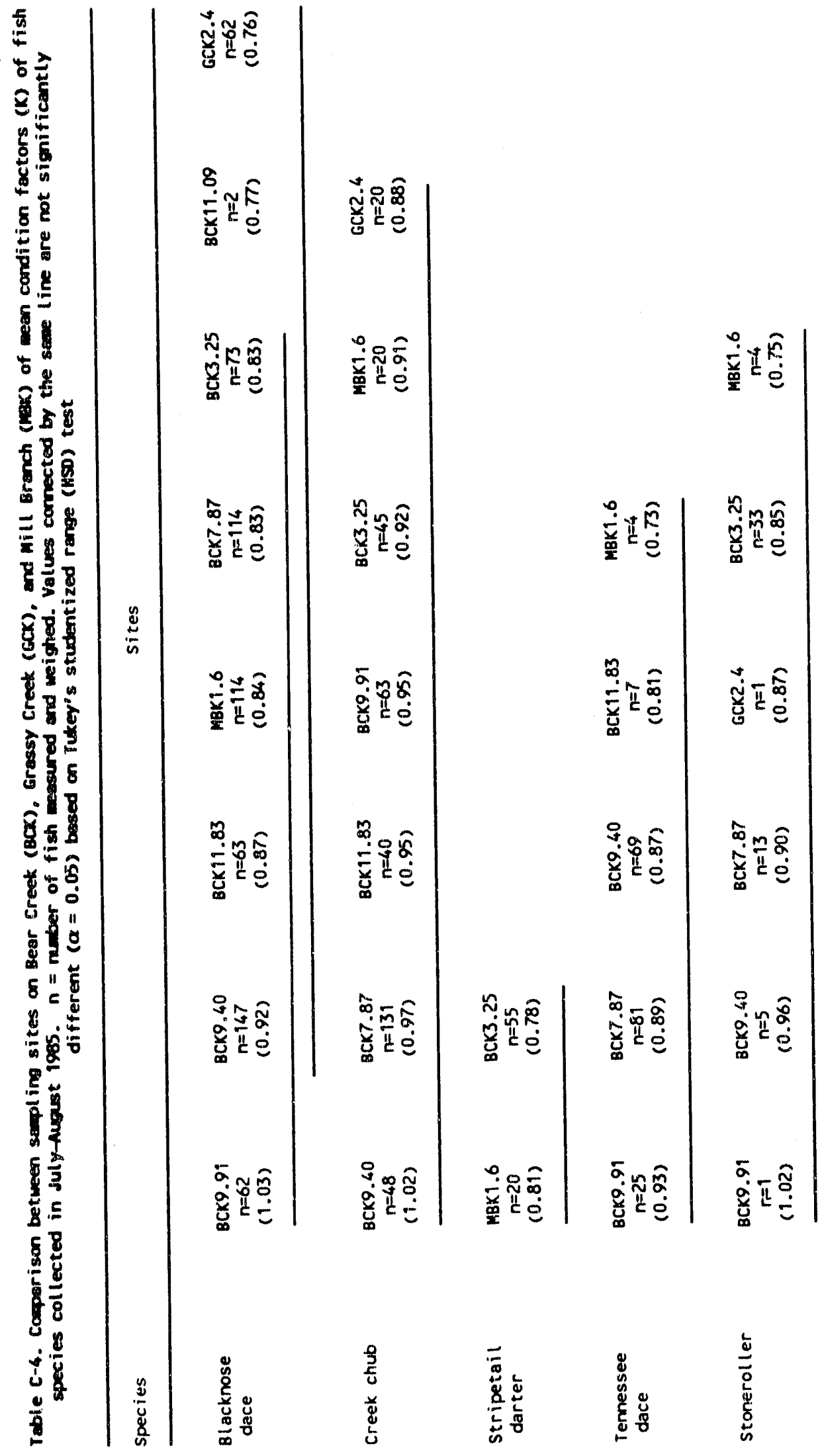


C. 15

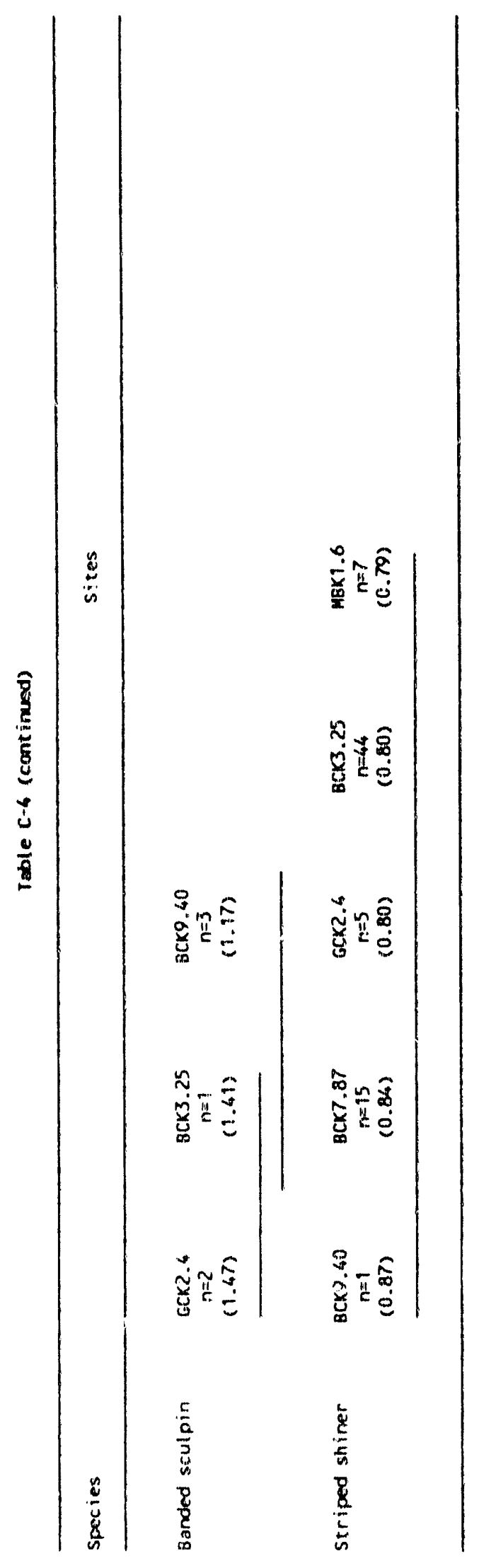




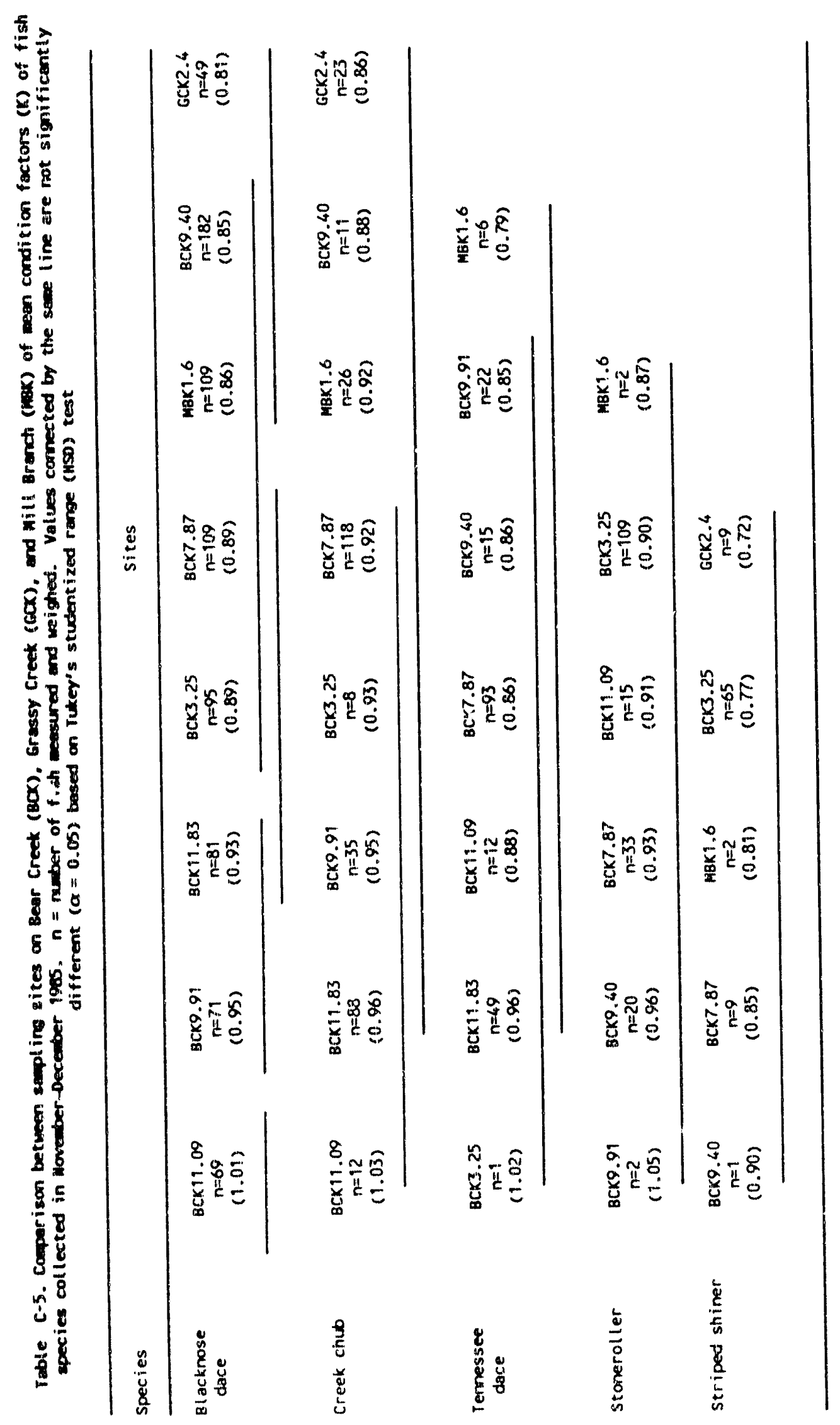




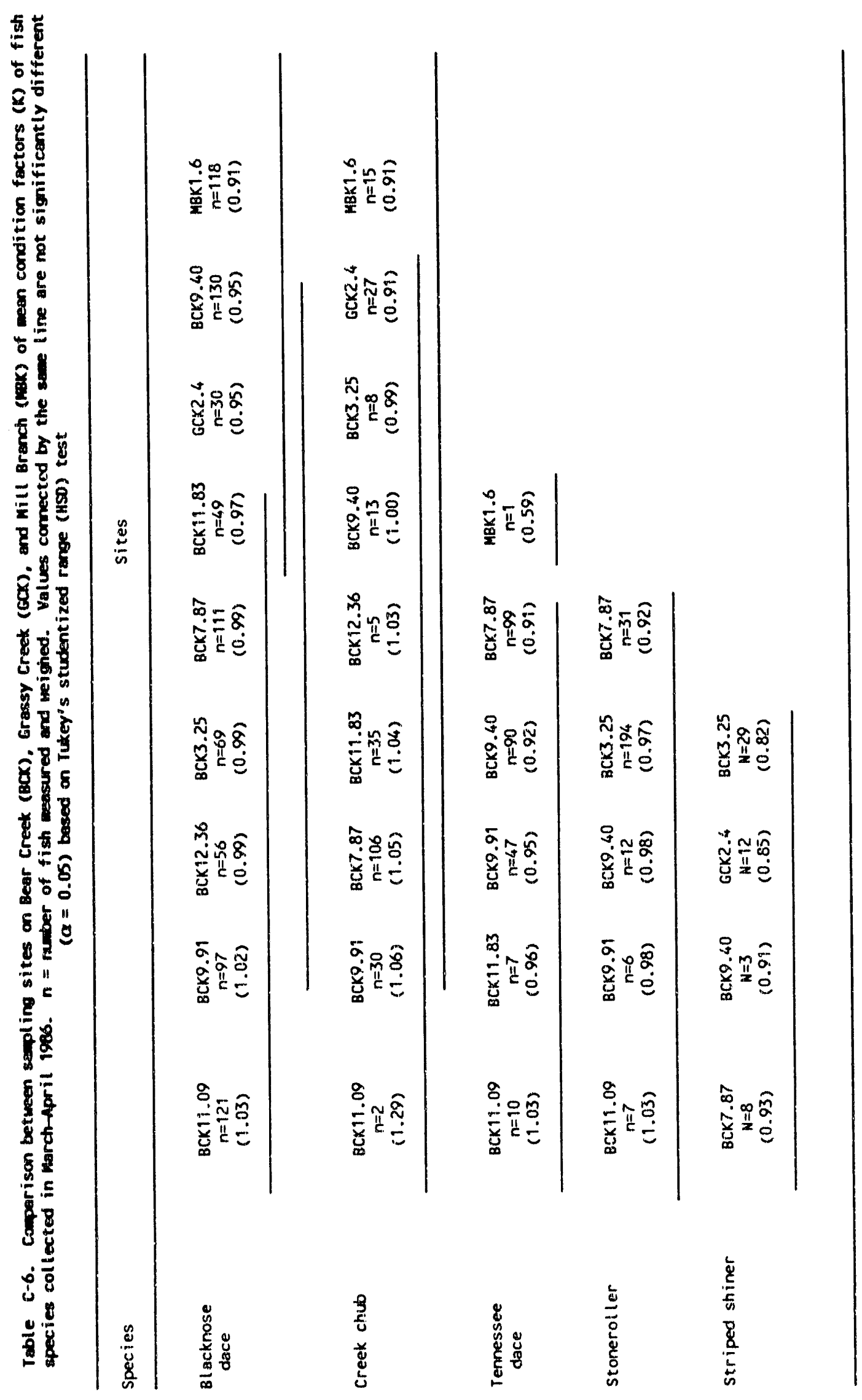




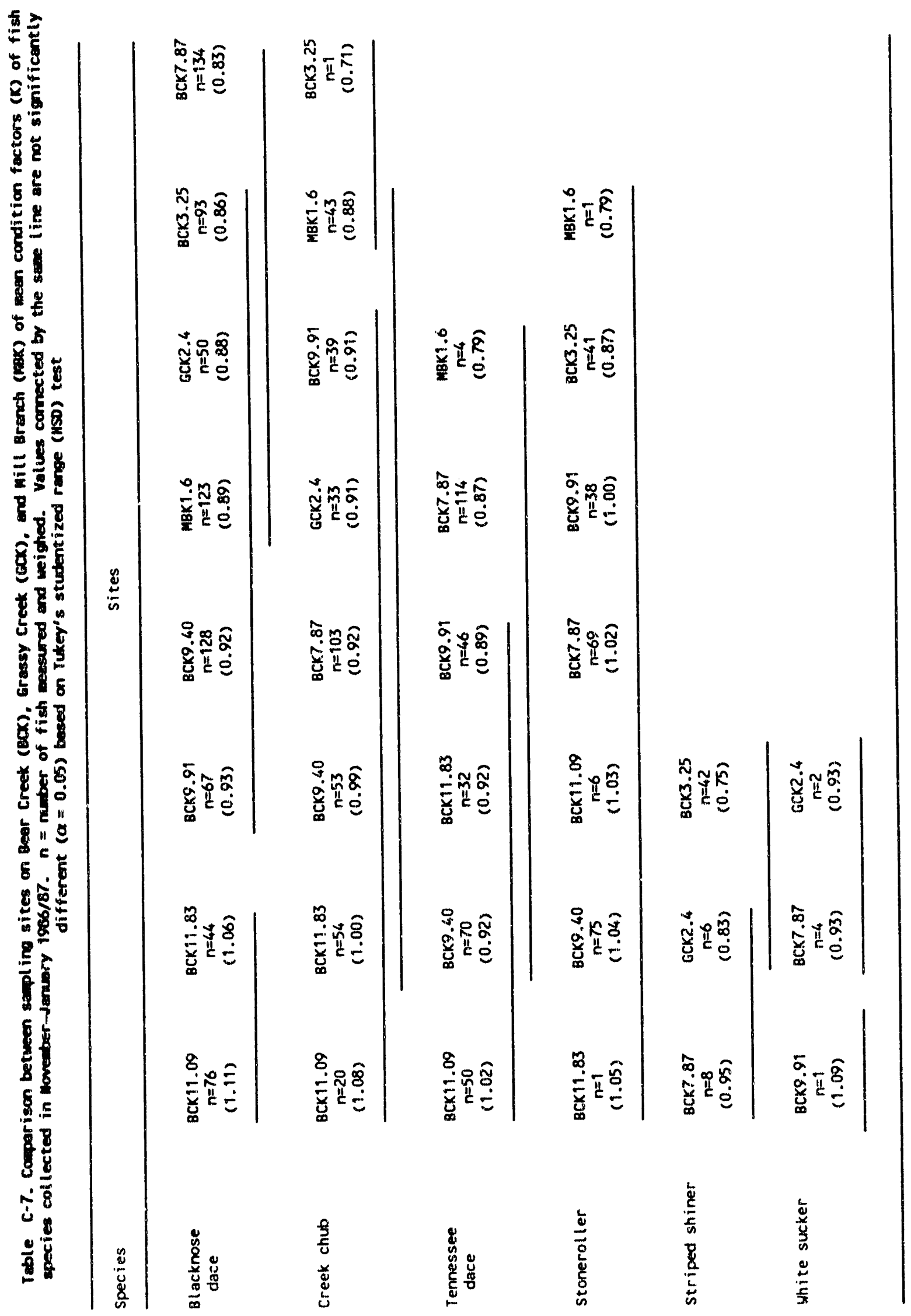



吾

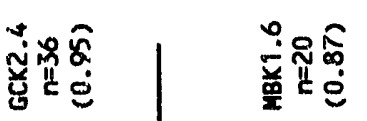

हु

密

8

늘

造

है

客要

ธै

8

造

过安

\&"

8

8 "

$8=$

क

g

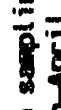

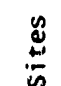

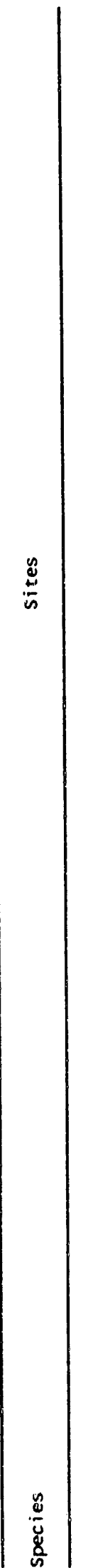

ํㅜㄹำ

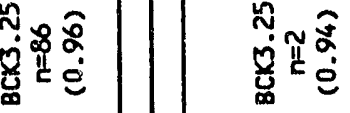

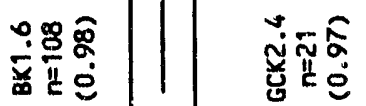

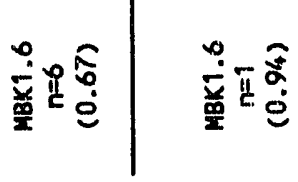

磁鱼客

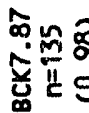

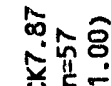

운

둘

華解

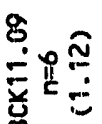

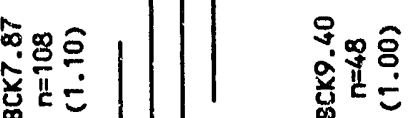

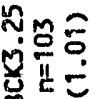

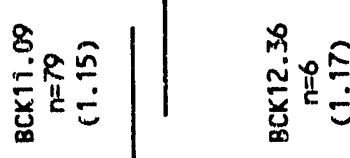

意蒙

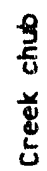

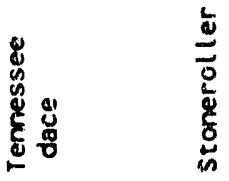


C -20

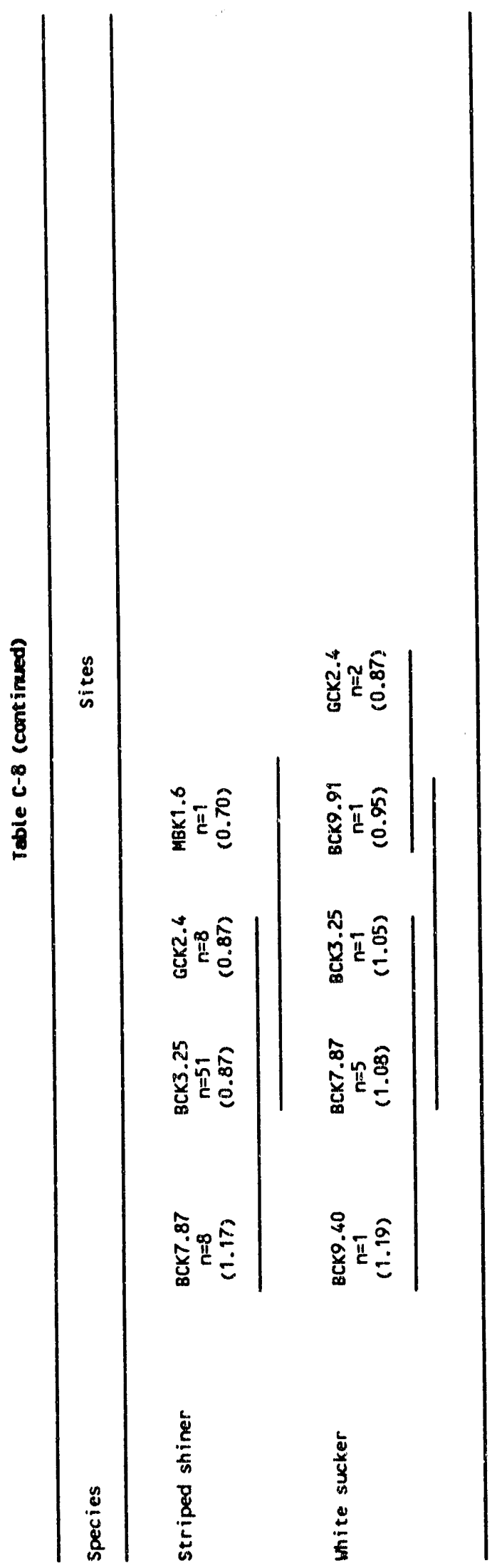




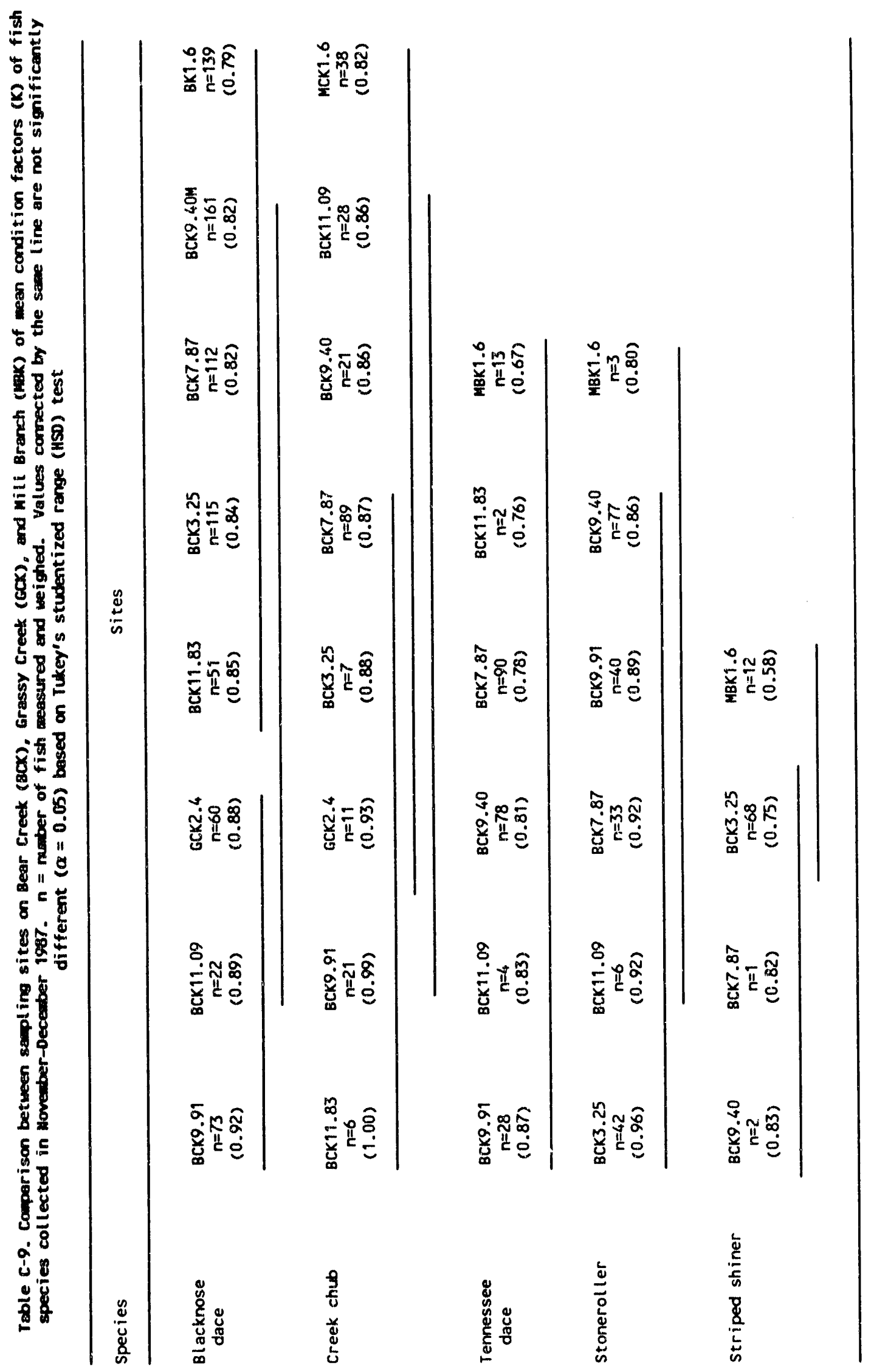


APPENDIX D

CHECKLIST OF BENTHIC MACROINVERTEBRATE TAXA FROM

BEAR CREEK AND GRASSY CREEK, JUNE 1984-JULY 1987 
D- 3

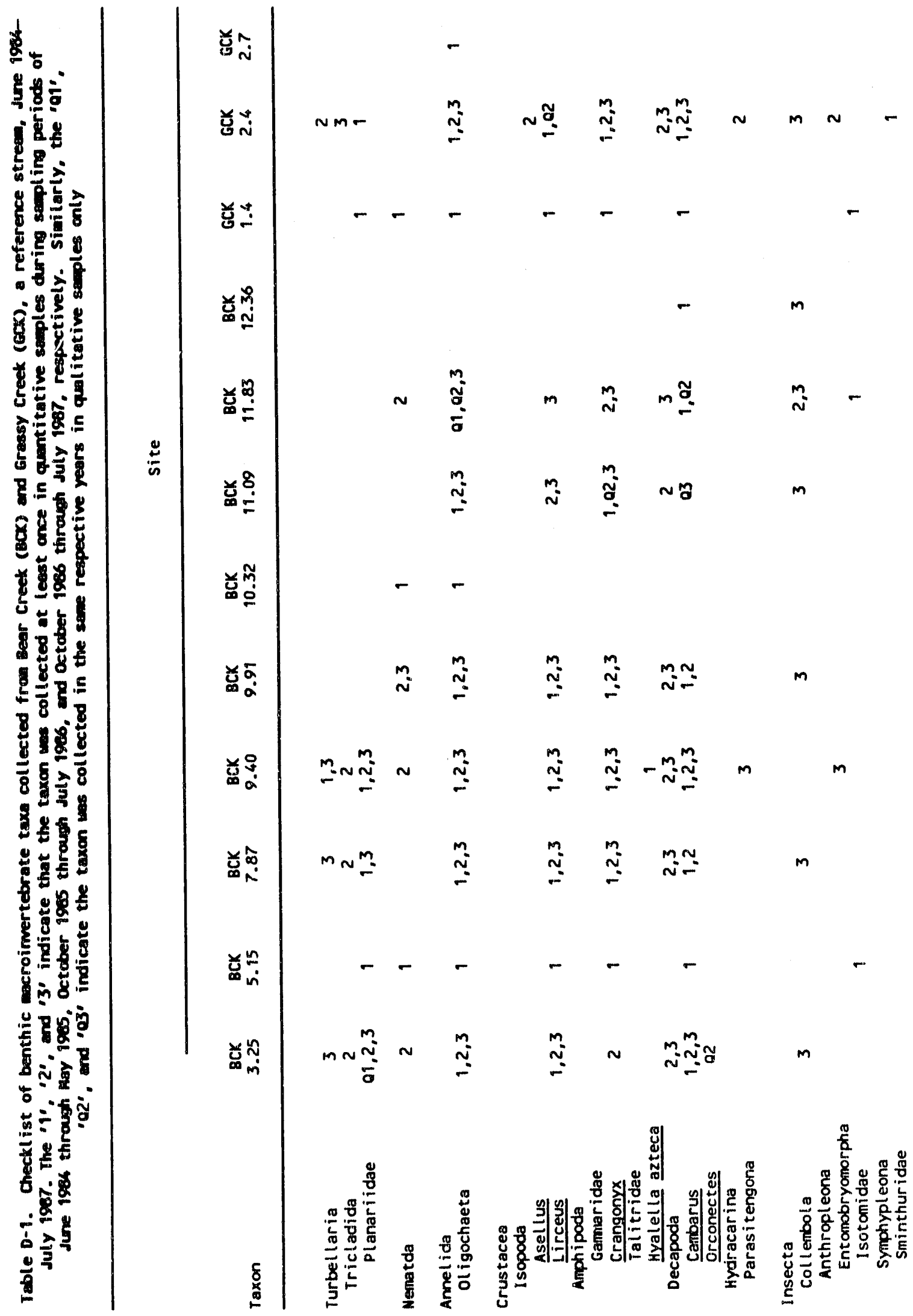




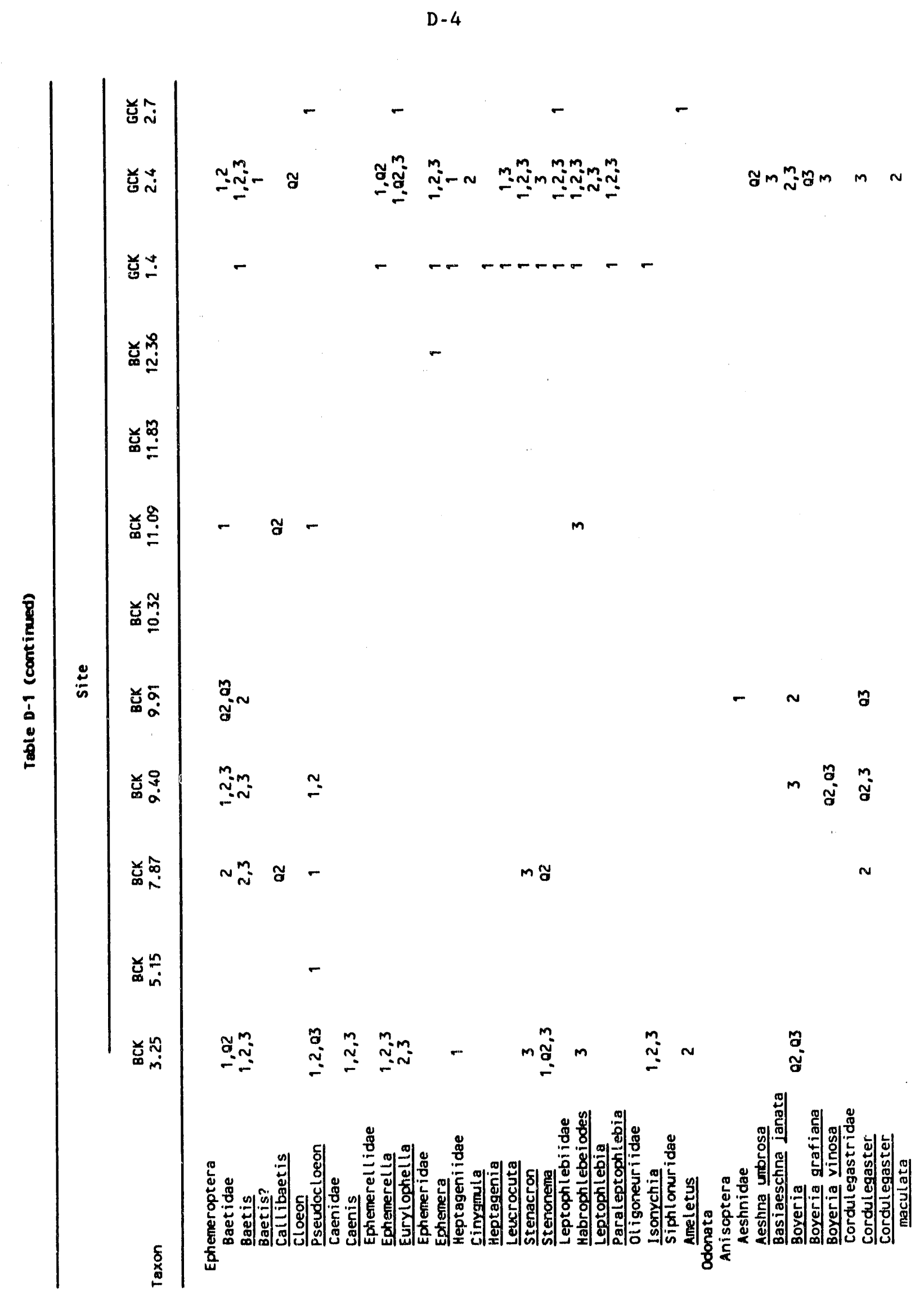


D- 5

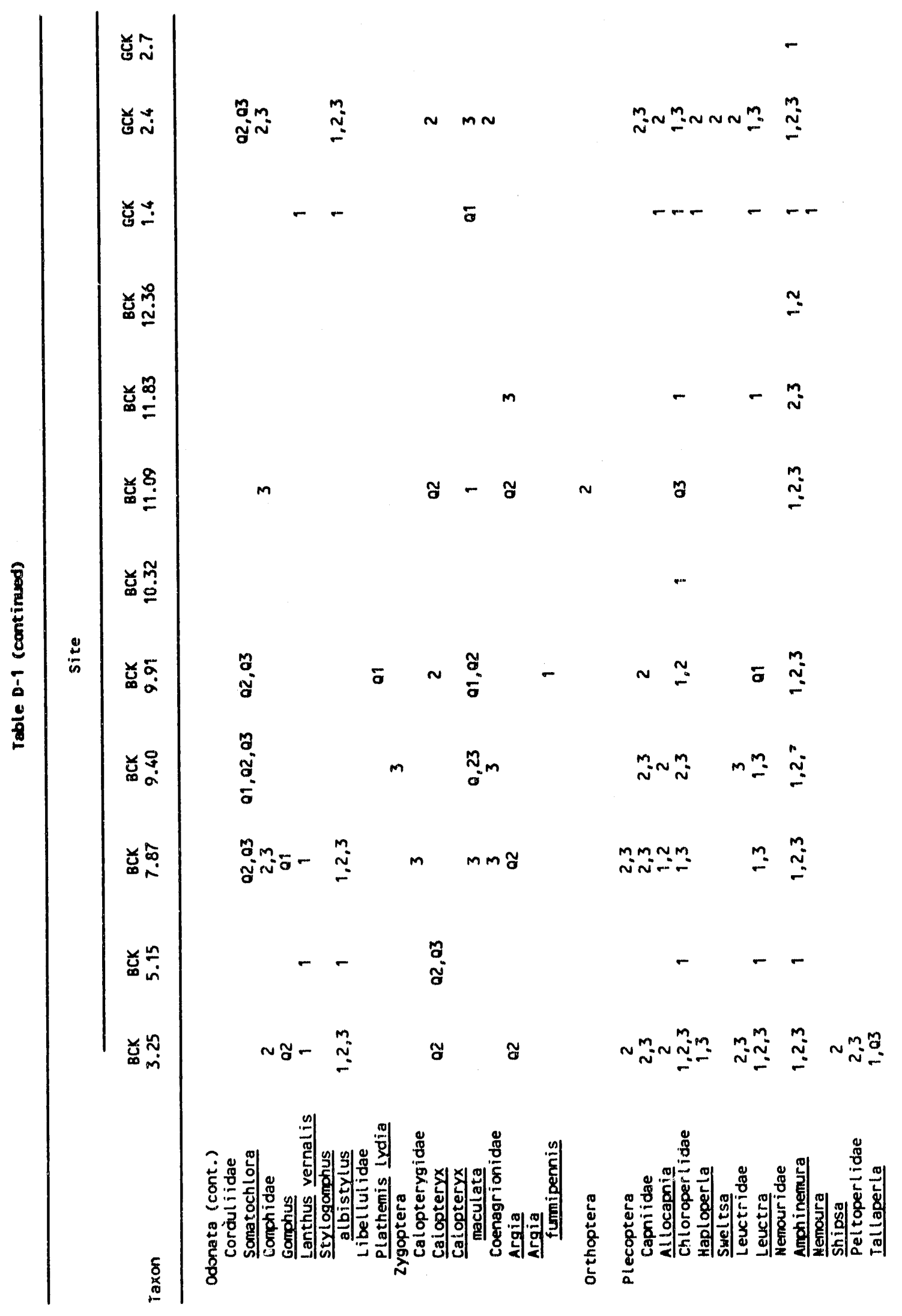


D -6

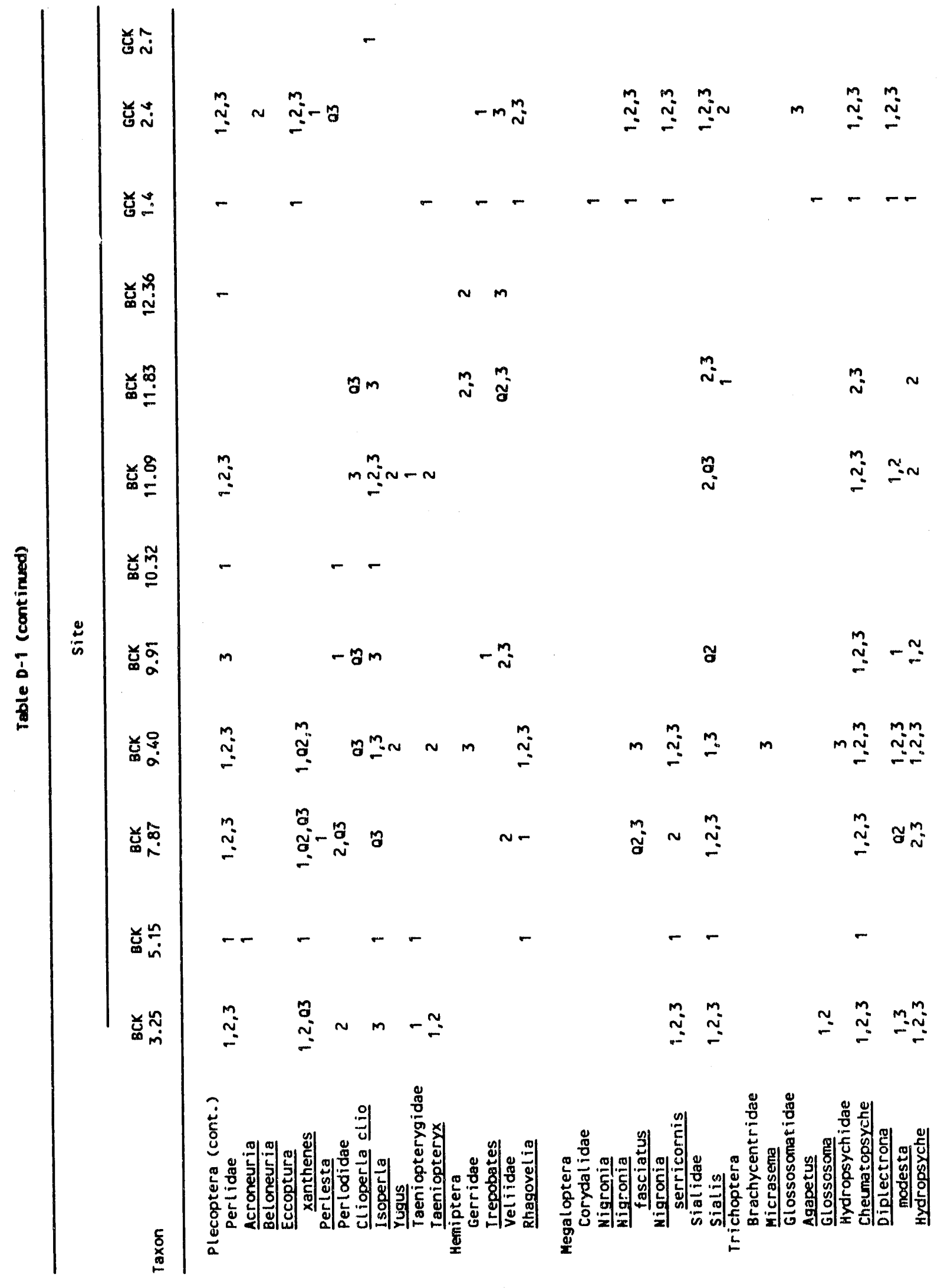


D- 7

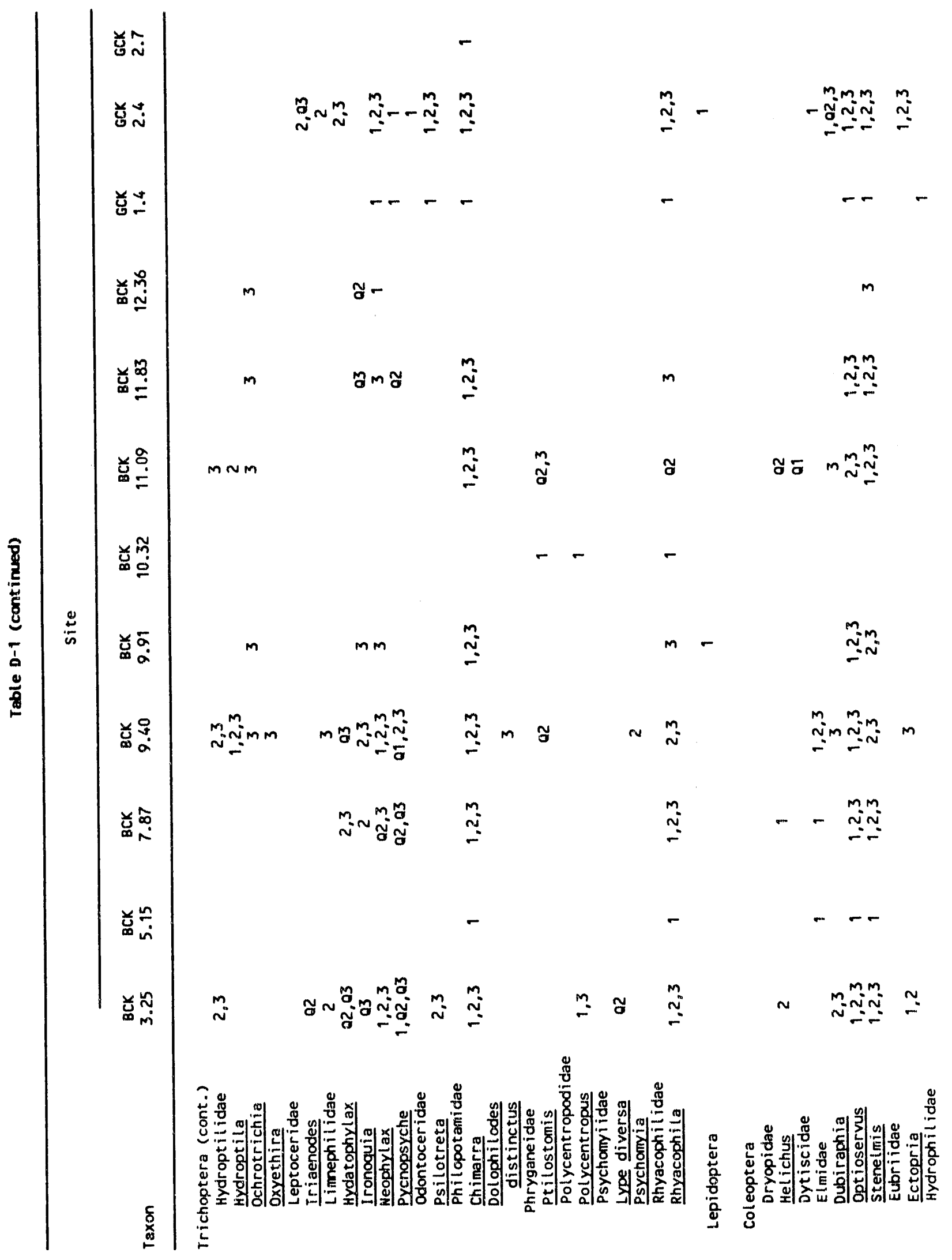




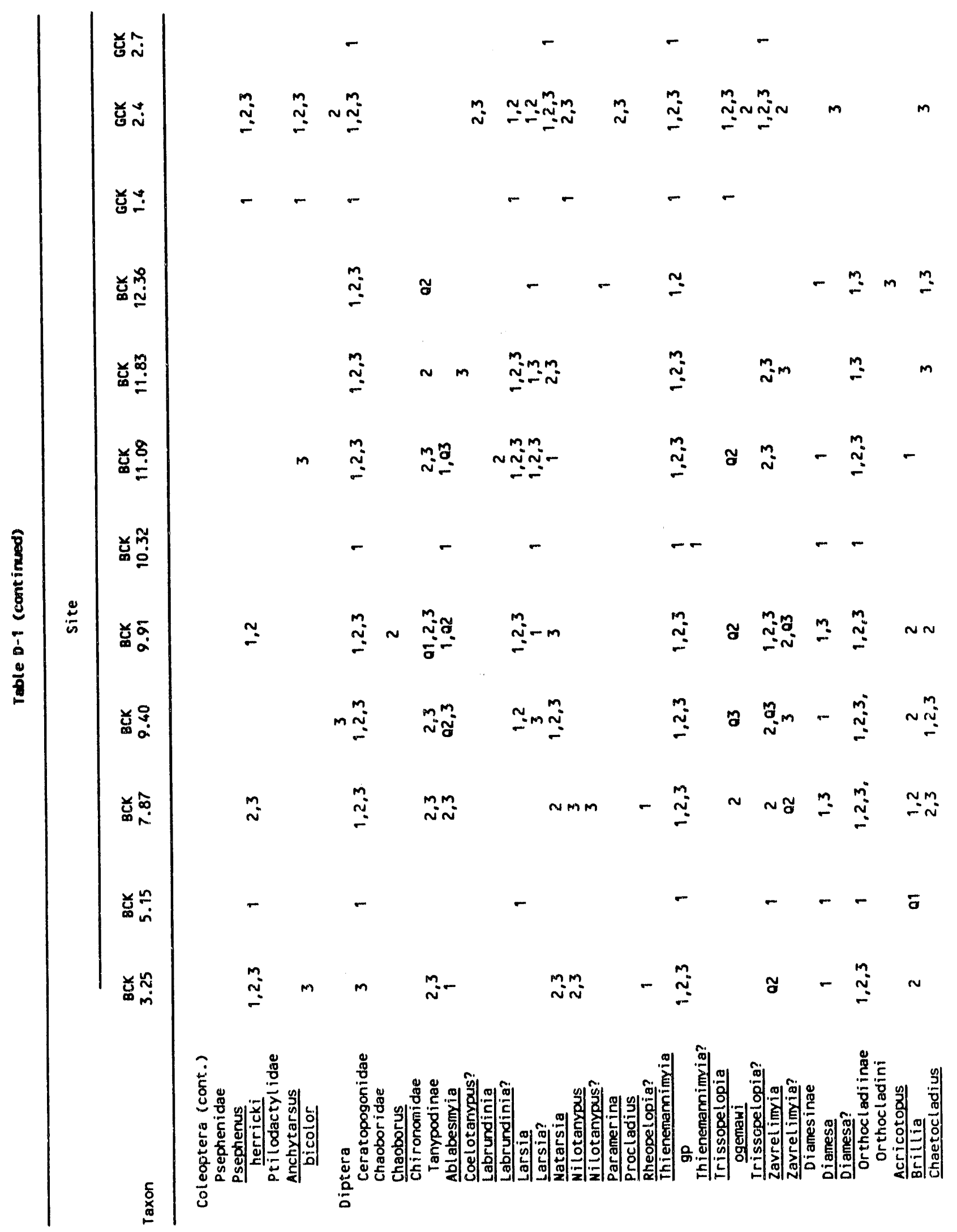


D- 9

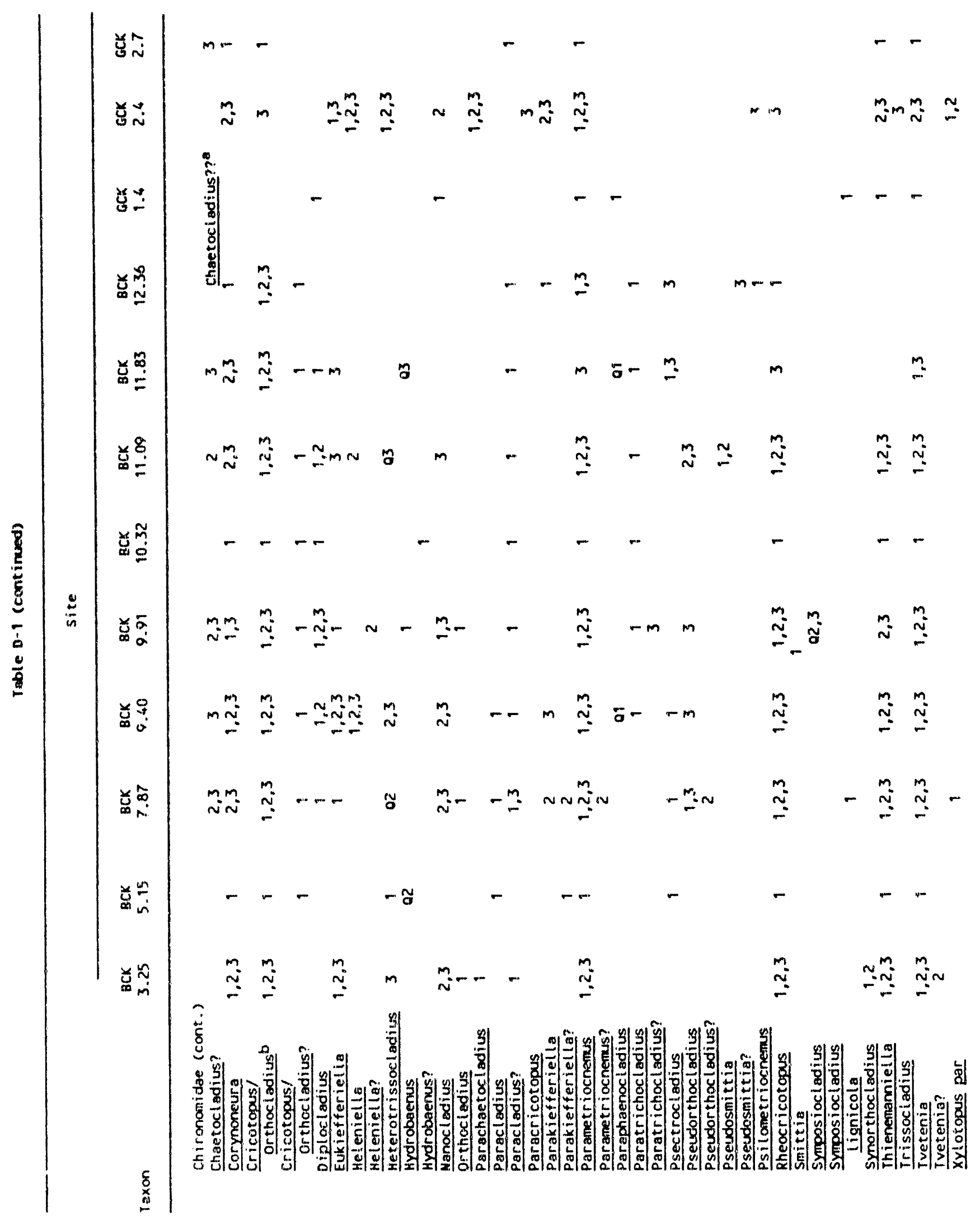


D -10

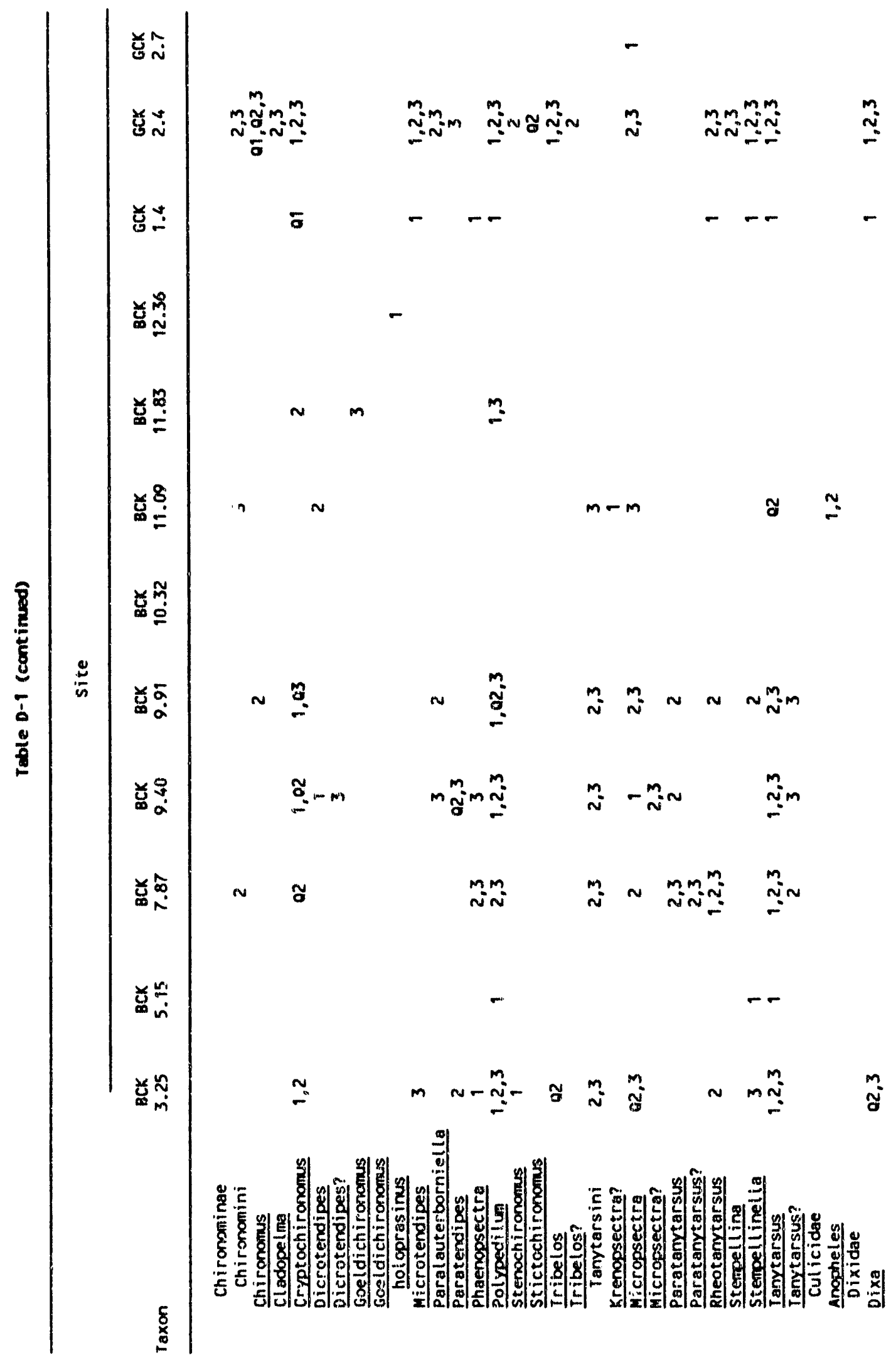


D- 11

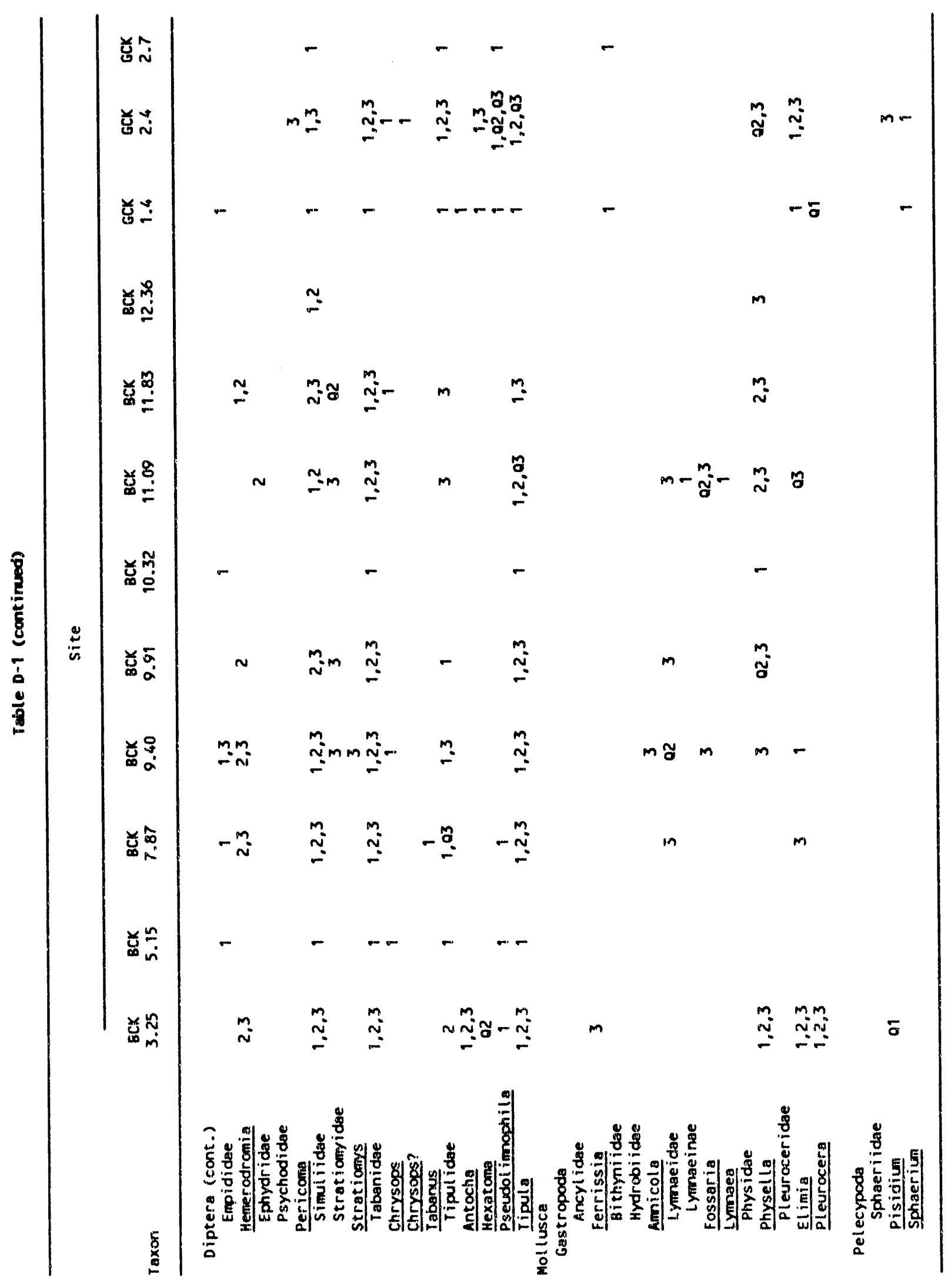


APPENDIX E

CHECKLIST OF BENTHIC MACROINVERTEBRATE TAXA FROM BEAR CREEK REFERENCE STREAMS, OCTOBER 1984-JULY 1987 


\section{E-3}

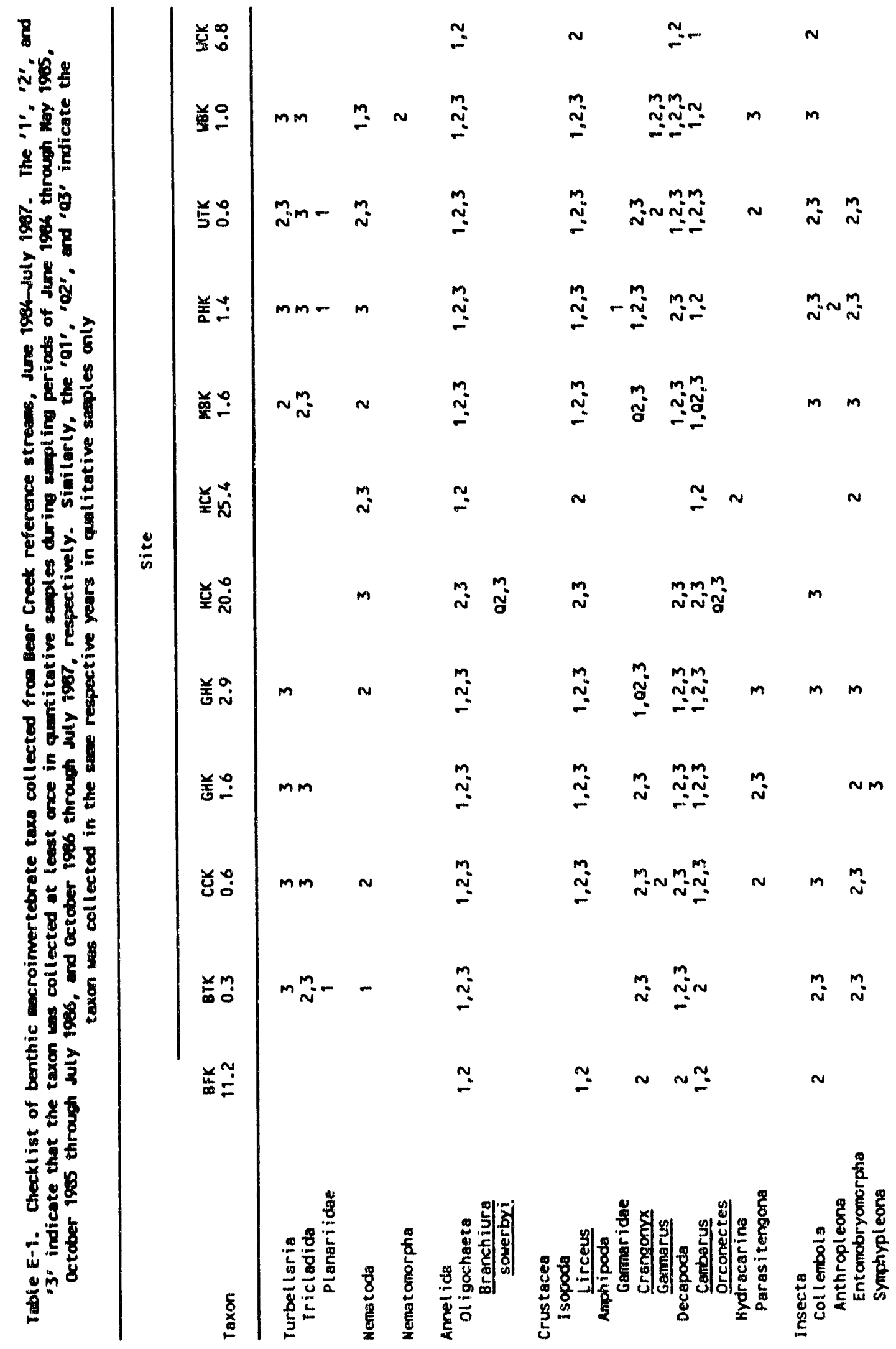


E-4

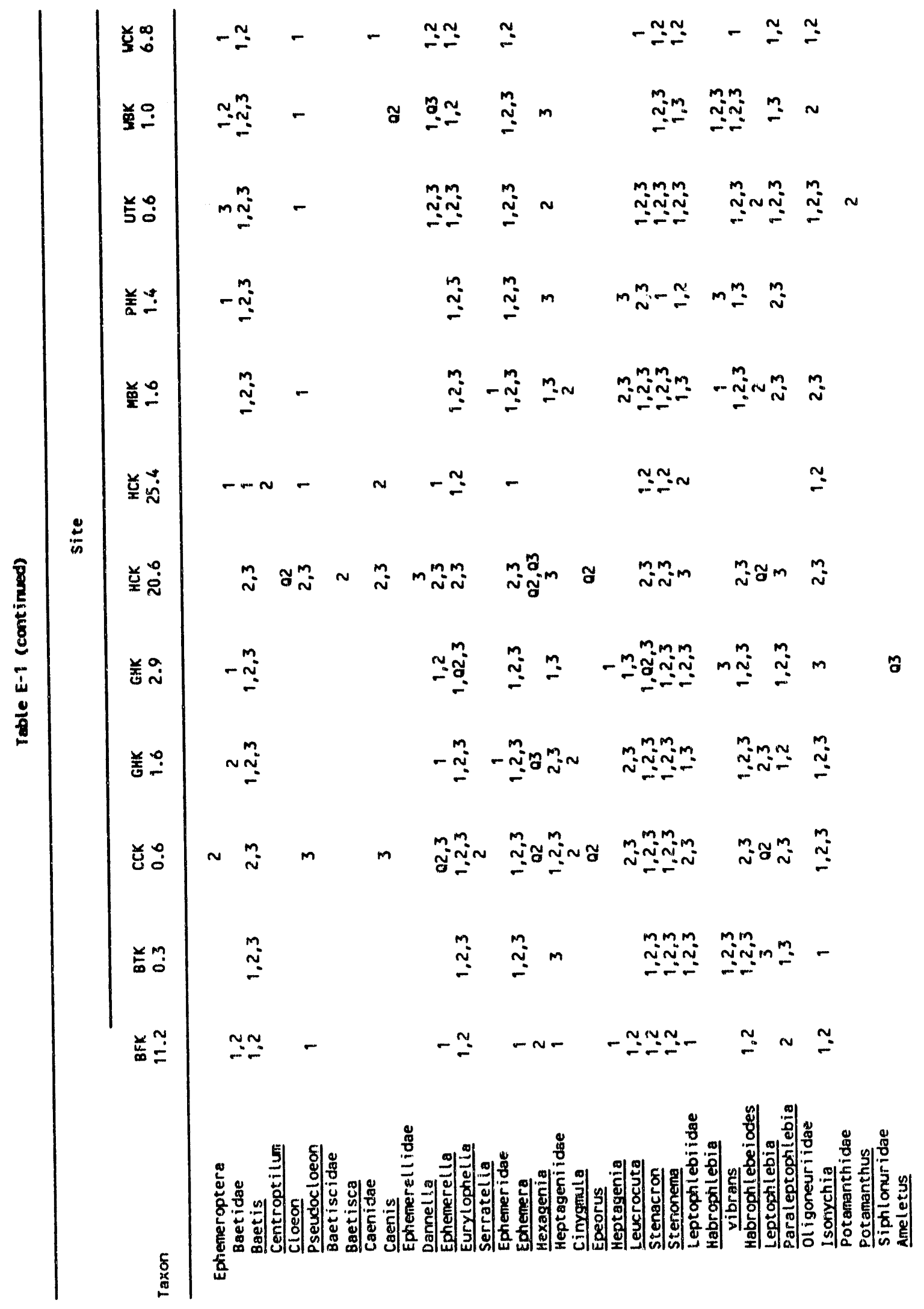




$$
\text { E- } 5
$$

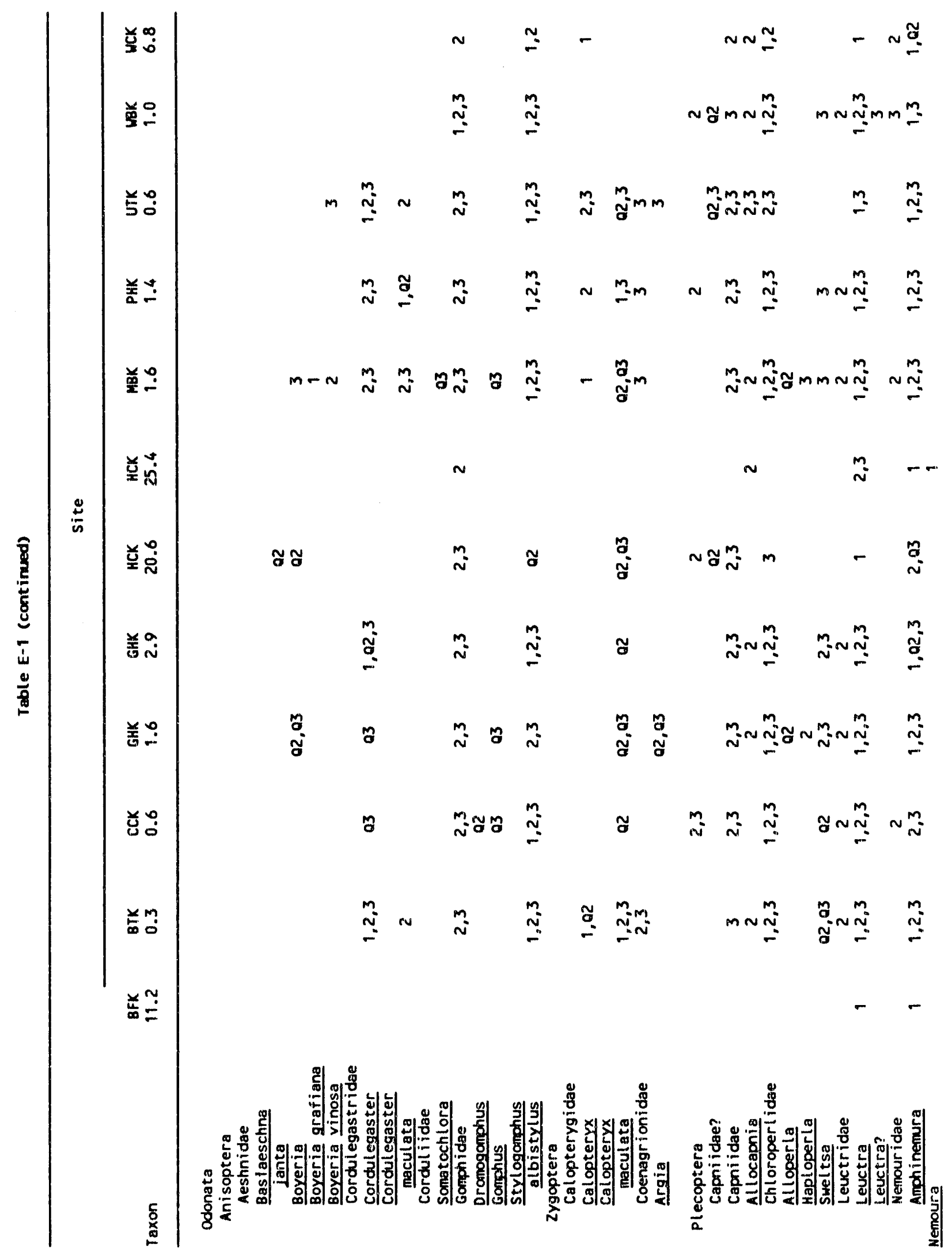




$$
\begin{aligned}
& \text { E- } 6
\end{aligned}
$$

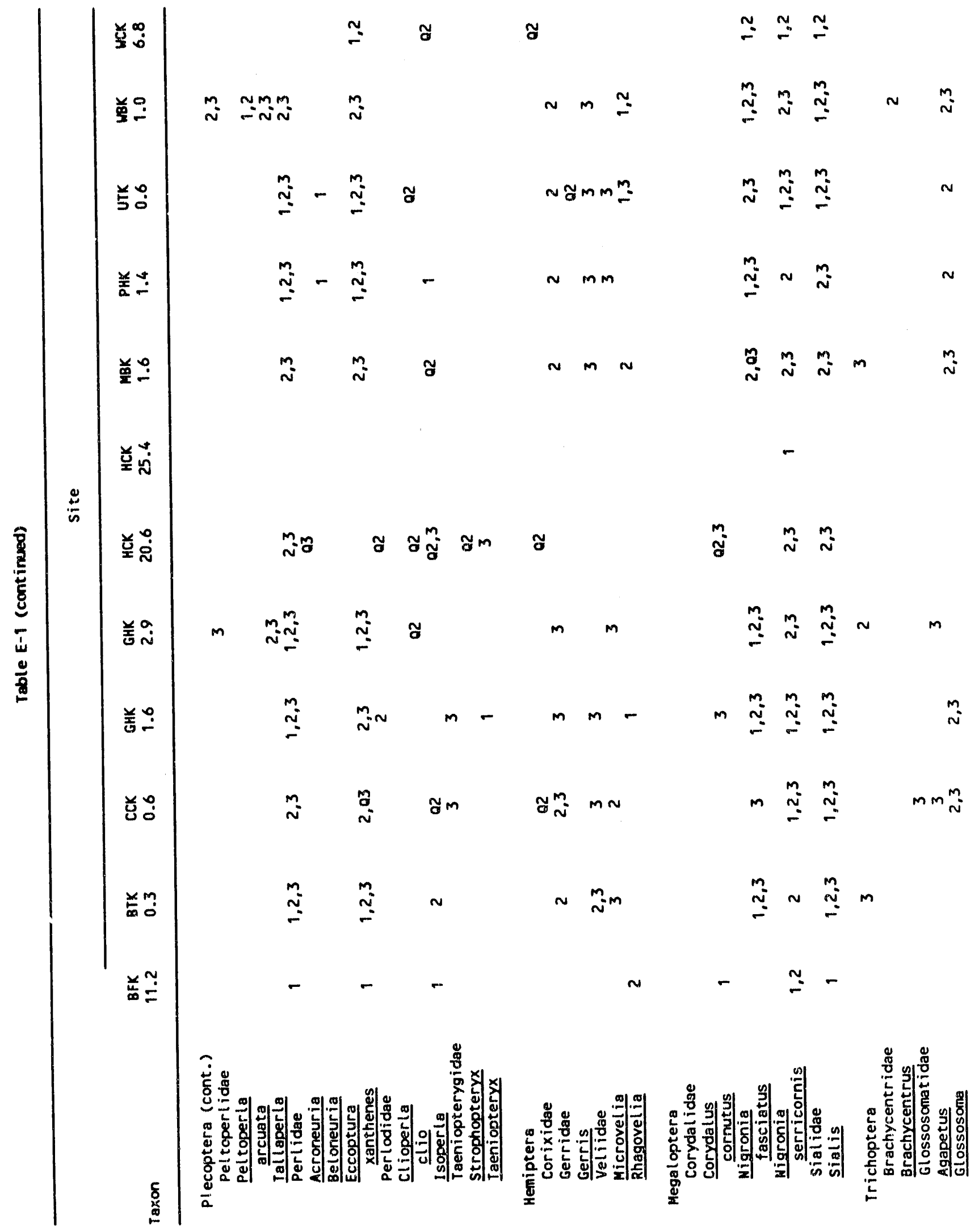


E-7

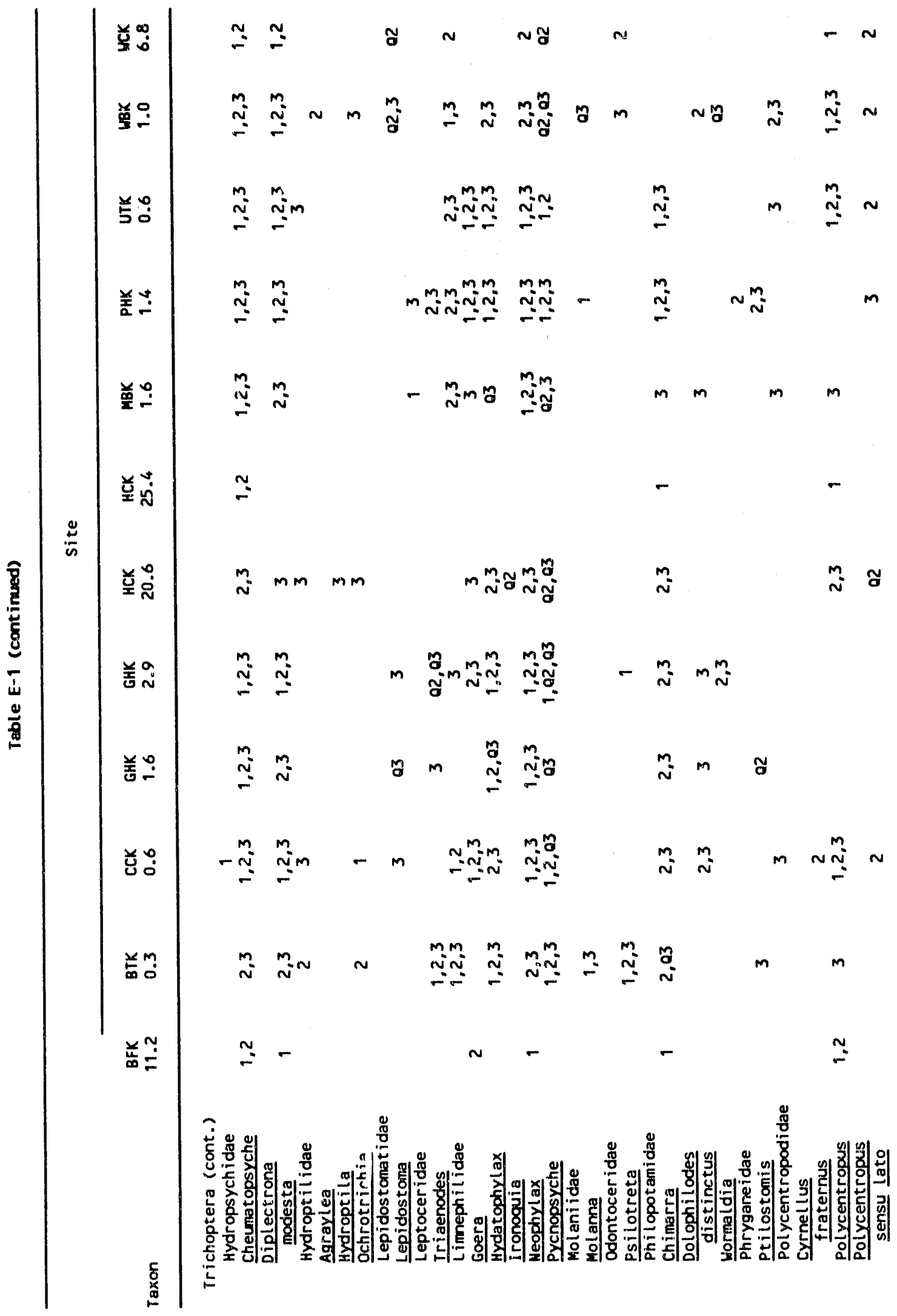




$$
\text { E- } 8
$$

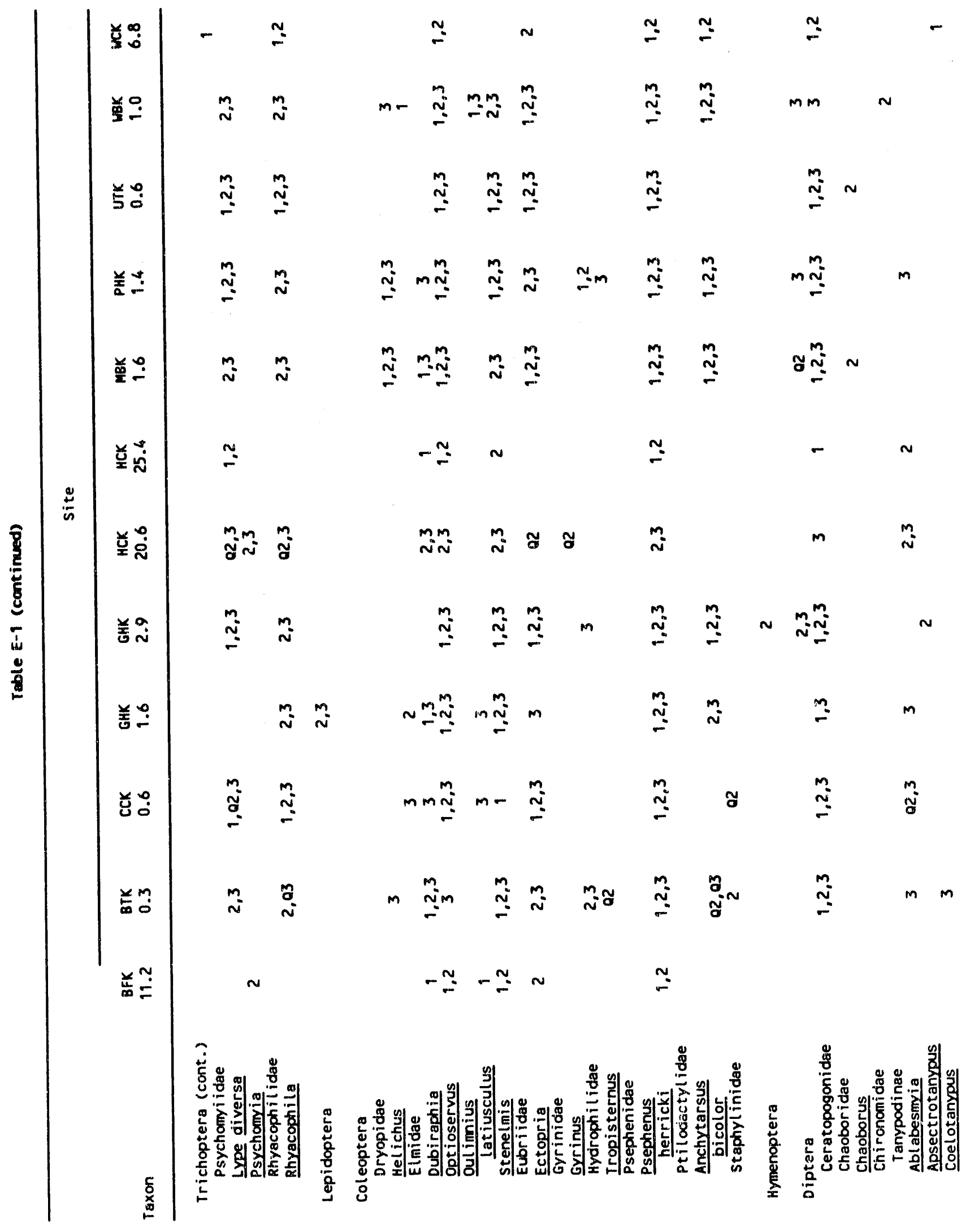


E-9

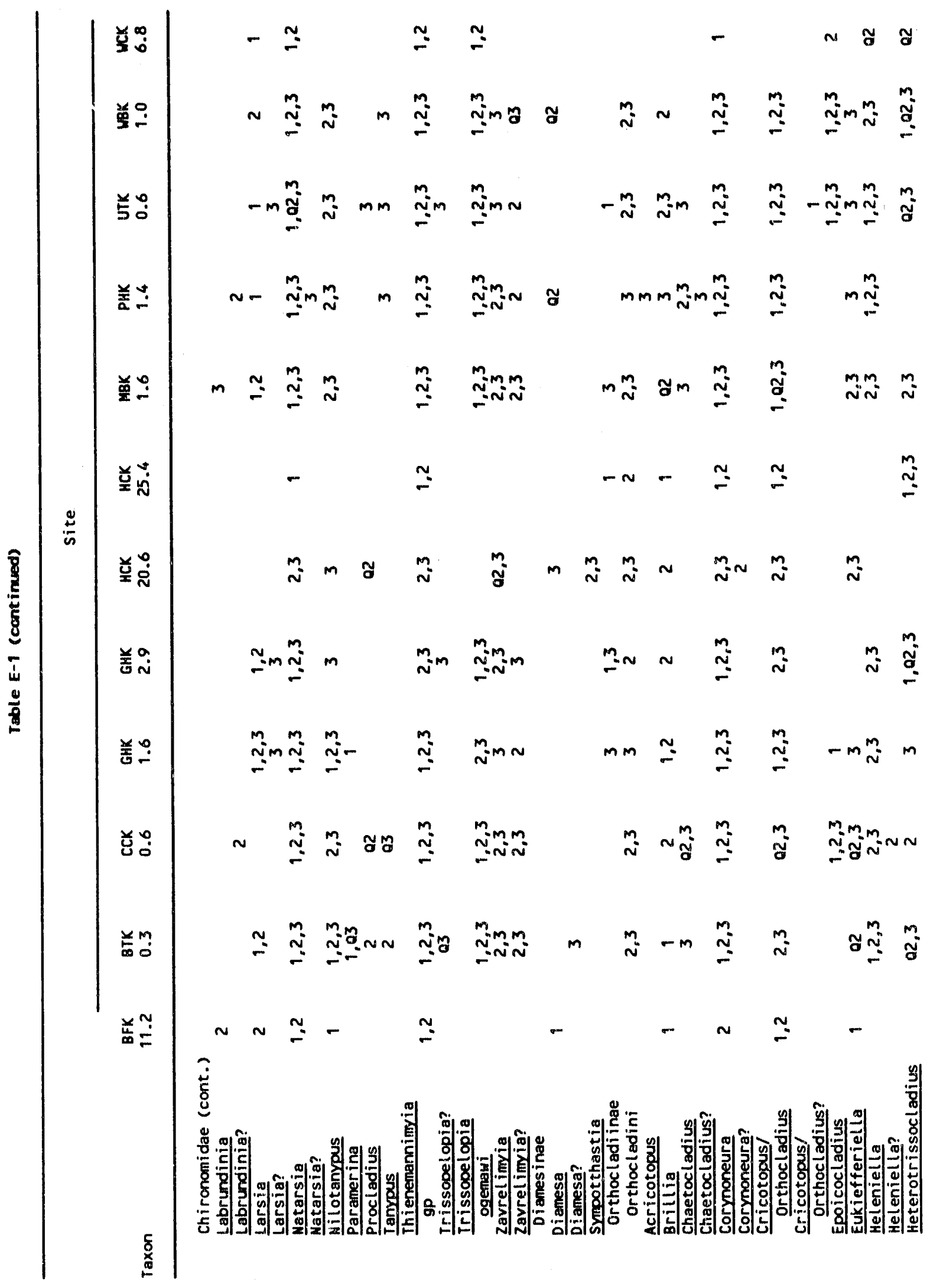




$$
\text { E-10 }
$$

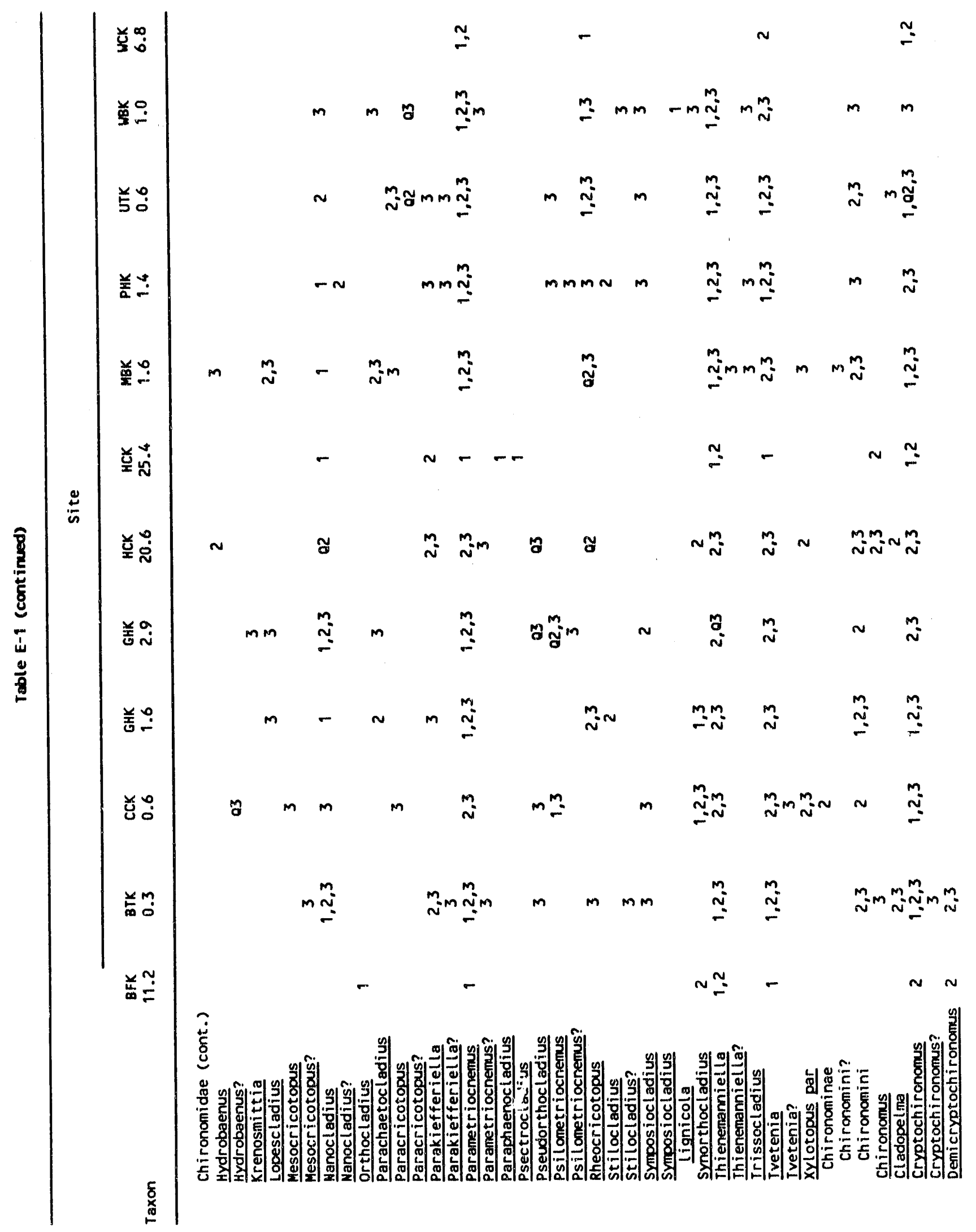


E-11

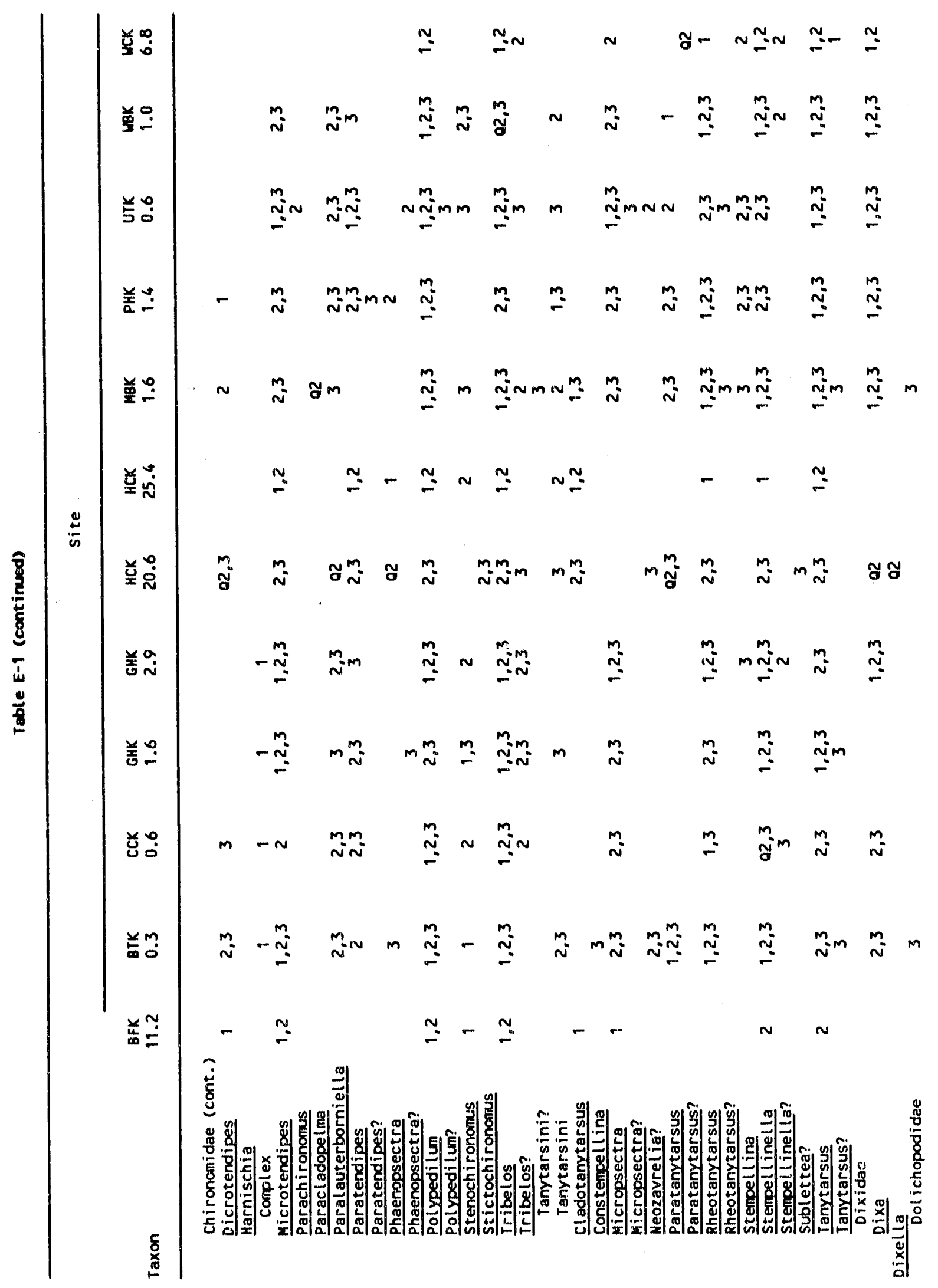




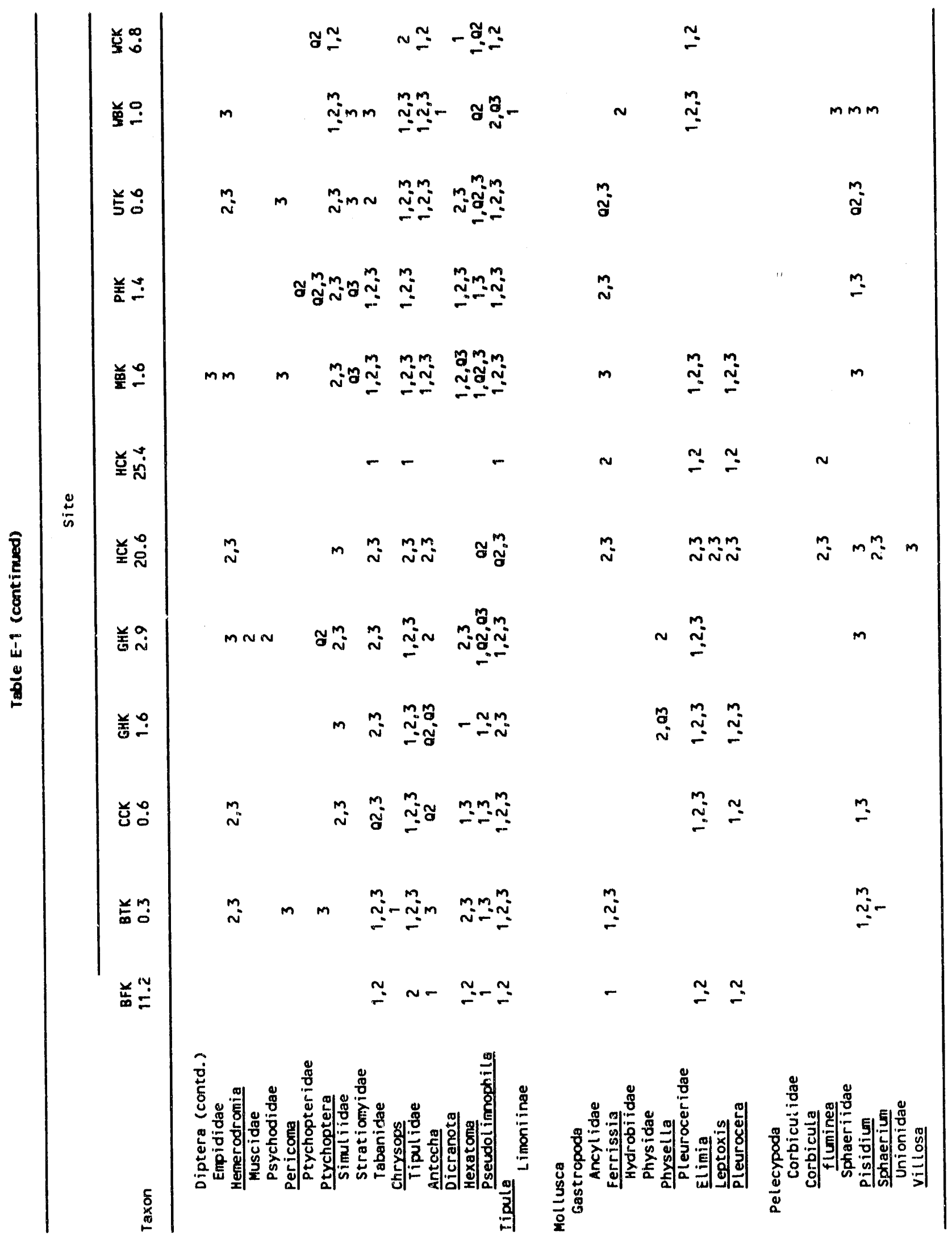




\section{APPENDIX F \\ STATISTICAL COMPARISONS OF DENSITY AND BIOMASS OF BENTHIC MACROINVERTEBRATES}




$$
\text { F-3 }
$$

Table F-1. Comparisons of mean benthic macroinvertebrate density in Bear Creek, June 1984-July 1987. Sites connected by the same Iine are not significantly different $(p<0.05$ ) based on 'Tukey's studentized range (HSD) test. Sites are arranged in order of highest to lowest values from left to right. Except where noted, differences are based on 10 sampling perlods in year 1 and 4 sampling periods in years 2 and 3

Year"site

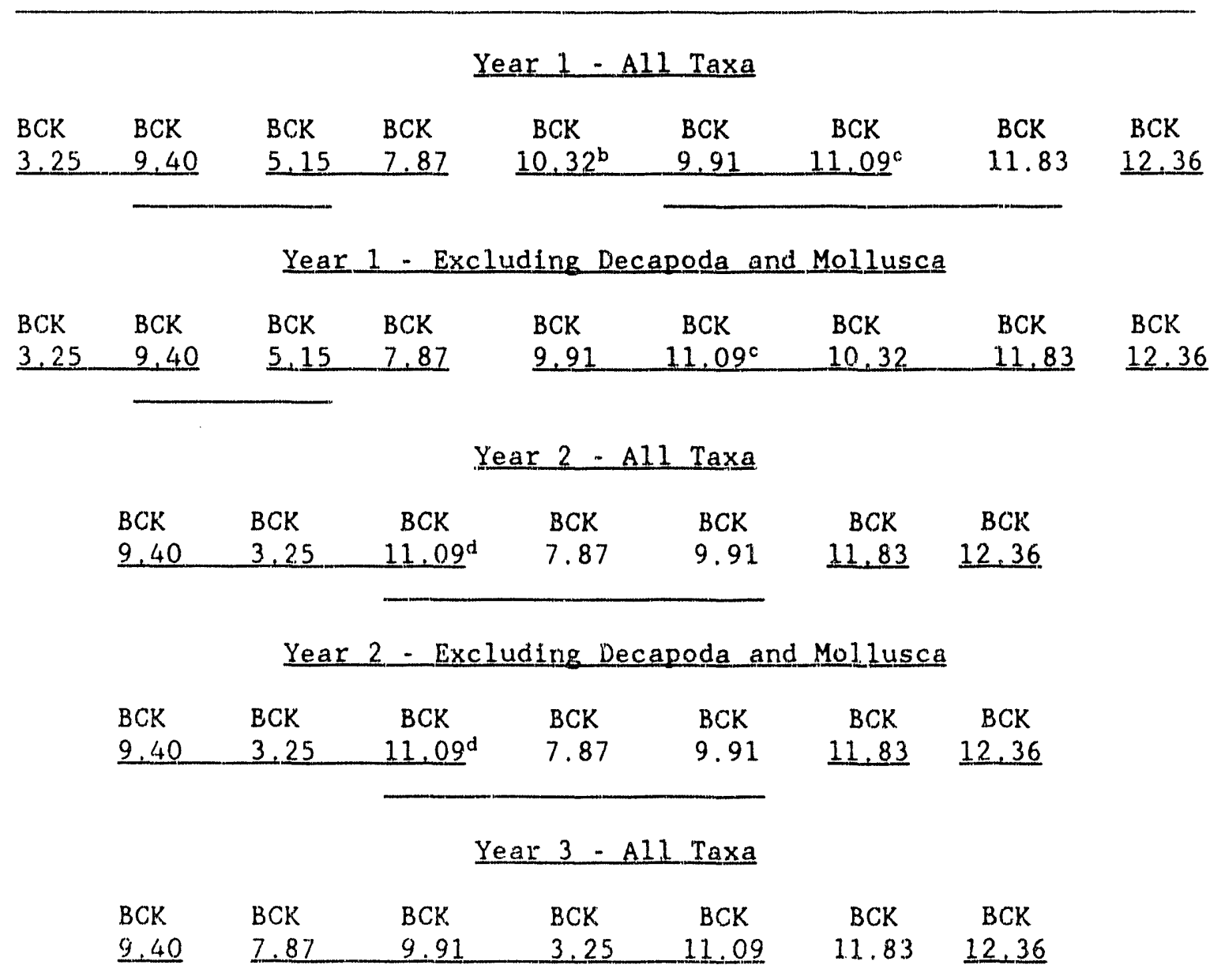

Year 3 - Excluding Decapoda and Mollusca

BCK BCK BCK $\quad$ BCK $\quad B C K \quad B C K \quad B C K$

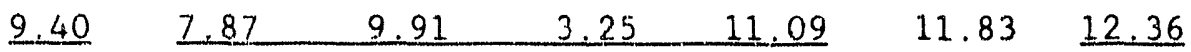

ayear 1 June 1984-May 1985, year 2 = October 1985-July 1986, and year 3 = October 1986-July 1987.

bexcludes June, August, and September 1984 when all sites were dry.

'Excludes September 1984 when site was dry.

dExcludes July 10g6 when stte was dry. 


$$
\text { F }-4
$$

Table F-2. Comparisons of mean benthic macroinvertebrate biomass in Bear Creek, June 1984-July 1987. Sites connected by the same line are not significantly different $(p<0.05$ ) based on Tukey's studentized range (HSD) test. Sites are arranged in order of highest to lowest values from left to $x$ lght. Except where noted, differences are based on 10 sampling periods in year 1 and 4 sampling periods in years 2 and 3

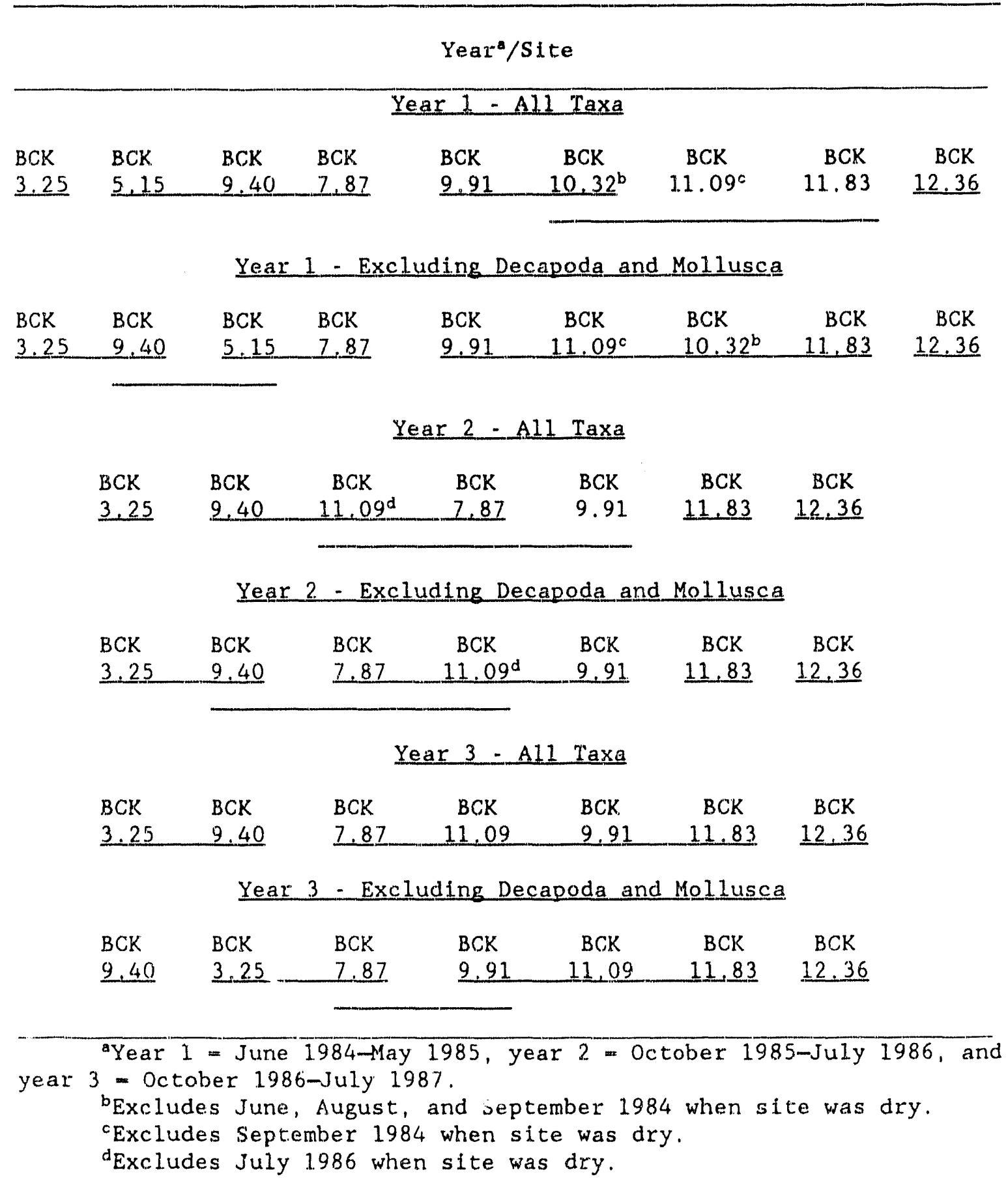




$$
\text { F }-5
$$

Table F-3. Comparisons of mean benthic macroinvertebrate density for Bear Creek reference streams, June 1984-July 1987. Sites connected by the same line are not significantly different $(p<0.05$ ) based on Tukey's studentized range (HSD) test. Sites are arranged in order of highest to lowest values from left to right. Differences are based on two sampling perlods in year 1 and four sampling perlods each in years 2 and 3

Year $/$ Site

Year 1 - All Taxa

UTK PHK WBK BFK WCK GHK BTK CCK GHK GCK MBK GCK HCK

$\begin{array}{lllllllllllll}0.6 & 1.4 & 1.0 & 11.2 & 6.8 & 1.6 & 0.3 & 0.6 & 2.9 & 1.4 & 1.6 & 2.4 & 25.4\end{array}$

Year 1 - Excluding Decapoda and Mollusca

\begin{tabular}{rrrrrrrrrrrrr} 
UTK & PHK & BFK & WBK & GHK & BTK & WCK & CCK & GHK & MBK & GCK & HCK & GCK \\
0.6 & 1.4 & 11.2 & 1.0 & 1.6 & 0.3 & 6.8 & 0.6 & 2.9 & 1.6 & 1.4 & 25.4 & 2.4 \\
\hline
\end{tabular}

Year 2 - Al1 Taxa

\begin{tabular}{|c|c|c|c|c|c|c|c|c|}
\hline UTK & MBK & $\mathrm{CCK}$ & WBK & PHK & $\mathrm{B}^{\prime} \mathrm{TK}$ & GHK & GHK & GCK \\
\hline$\underline{0}, 6$ & 1.6 & 0.6 & 1.0 & 1.4 & 0.3 & 1.6 & 2.9 & 2.4 \\
\hline
\end{tabular}

Year 2 - Excluding Decapoda and Mollusca

\begin{tabular}{lllllllll} 
UTK & PHK & CCK & BTK & MBK & GHK & WBK & GHK & GCK \\
0.6 & 1.4 & 0.6 & 0.3 & 1.6 & 1.6 & 1.0 & 2.9 & 2.4 \\
\hline
\end{tabular}

Year 3 - Al1 Taxa

\begin{tabular}{llllllrlrl} 
UTK & MBK & PHK & GHK & CCK & WBK & HCK & BTK & GHK & GCK \\
$\underline{0.6}$ & 1.6 & 1.4 & 2.9 & 0.6 & 1.0 & 20.6 & 0.3 & 1.6 & 2.4 \\
\hline
\end{tabular}




$$
\text { F-6 }
$$

Table F-3 (continued)

\begin{tabular}{|c|c|c|c|c|c|c|c|c|c|}
\hline \multicolumn{10}{|c|}{ Year /Site } \\
\hline UTK & MBK & PHK & GHK & WBK & $\mathrm{CCK}$ & BTK & $\mathrm{HCK}$ & GHK & GCK \\
\hline 0.6 & 1.6 & 1.4 & 2.9 & 1.0 & 0.6 & 0.3 & 20.6 & 1.6 & 2.4 \\
\hline
\end{tabular}

aYear 1 - June 1984-May 1985, Year 2 - Octobex 1985-July 1986, and year 3 - October 1986-July 1987 . 
Table F-4. Comparisons of mean benthic macrolnvertebrate biomass for Bear Creek reference streams, June 1984-July 1987. Sites connected by the same line are not significantly different $(p<0.05)$ based on Tukey's studentized range (HSD) test. Sites are arranged in order of highest to lowest values from left to right. Differences are based on two sampling periods in year 1 and four sampling perlods each in years 2 and 3

Year"site

Year 1 - A11 Taxa

BFK UTK WBK GCK GCK WCK GHK PHK MBK CCK GHK BTK HCK

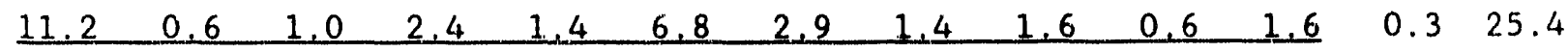

Year 1 - Excluding Decapoda and Mollusca

UTK PHK BFK GHK GHK WBK BTK CCK WCK GCK GCK MBK HCK

$\begin{array}{lllllllllllll}0.6 & 1.4 & 11.2 & 1.6 & 2.9 & 1.0 & 0.3 & 0.6 & 6.8 & 1.4 & 2.4 & 1.6 & 25.4\end{array}$

Year 2 - All Taxa

\begin{tabular}{lllllllll} 
GCK & MBK & WBK & GHK & GHK & CCK & UTK & PHK & BTK \\
2.4 & 1.6 & 1.0 & 1.6 & 2.9 & 0.6 & 0.6 & 1.4 & $\underline{0.3}$ \\
\hline
\end{tabular}

Year 2 -Excluding Decapoda and Mollusca

\begin{tabular}{lllllllll} 
PHK & UTK & GHK & GHK & MBK & WBK & CCK & BTK & GCK \\
1.4 & 0.6 & 1.6 & 2.9 & 1.6 & 1.0 & 0.6 & 0.3 & 2.4 \\
\hline
\end{tabular}

Year $3-$ Al1 Taxa

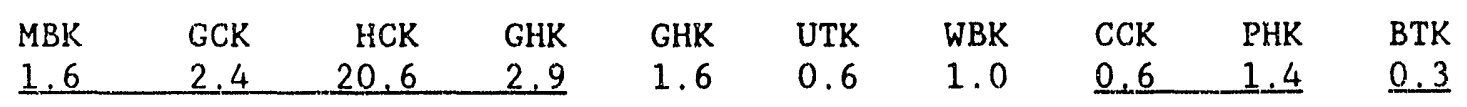


F- 8

Table F-4 (continued)

Year $/$ Site

Year 3 - Excluding Decapoda and Mollusca

UTK MBK PHK GHK WBK GCK GHK CCK BTK HCK

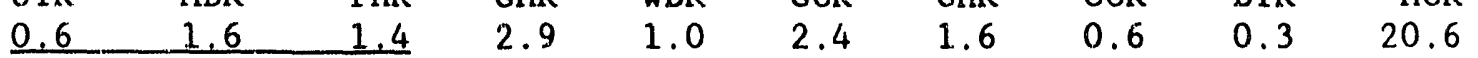

Year 1 - June 1984-May 1985, year 2 - October 1985-July 1986, and year 3 - October 1986-July 1987. 
Table F-5. Within-site comparisons of temporal changes in density of benthic macroinvertebrates in Bear Creek, June 1984-July 1987. Years connected by the same line are not significantly different $(p<0.05)$ based on Tukey's studentized range (HSD) test. Years are arranged in order of highest to lowest values from left to rightab

$\underline{B C K ~} 3.25$

Year 2 Year 3 Year 1 Year 2 Year 3

Year 3 Year 2 Year 1 Year 3 Year 2

Year 3 Year 2 Year 1 Year 3 Year 2

Year 3 Year 2 Year 1 Year 3 Year 2

Year 2 Year 3 Year 1 Year 2 Year 3

Year 3 Year 2 Year 1 Year 3 Year 2

\section{Year 2 Year 3 Year 1} Year 2 Year 3

BCK 7.87

$$
\frac{\text { Year } 3 \text { Year } 2 \text { Year } 1}{\text { Year } 3 \text { Year } 2}
$$

BCK 9.40

$$
\frac{\text { Year } 3}{\text { Year } 3 \text { Year } 2} \text { Year } 2
$$

BCK 9.91

$\frac{\text { Year } 3 \text { Year } 2}{\text { Year } 3 \text { Year } 2}$

BCK 11.09

Year 2 Year 3 Year 1 Year 2 Year 3

BCK 11.83

$$
\frac{\text { Year } 3}{\text { Year } 3 \text { Year } 2 \text { Year } 2}
$$

BCK 12.36
Year 3 Year 1 Year 2 Year 3 Year 2
Year 3 Year 1 Year 2 Year 3 Year 2

aYear 1 - June 1984-May 1985, yeax 2 - October 1985-July 1986, and year 3 = October 1986-July 1987.

"Three-year comparisons are based on data from April, July, and October except for BCK 11.09, which is based on data from Apri1 and October only. Comparisons between years 2 and 3 are based on all sampling dates except for BCK 11.09, which is based on data from January, April, and October only. 


\section{F -10}

Table F-6. Within-site comparisons of temporal changes in biomass of benthic macroinvertebrates in Bear Creek, June 1984-July 1987. Years connected by the same line are not significantly different $(p<0.05)$ based on Tukey's studentized range (HSD) test. Years are arranged in order of highest to lowest values from left to right ${ }^{\star b}$

BCK 3.25

Year 3 Year 2 Year 1 Year 2 Year 3

Year 3 Year 1 Year 2 Year 3 Year 2

Year 3 Year 2 Year 1 Year 3 Year 2

Year 3 Year 2 Year 1 Year 2 Year 3

Year 2 Year 3 Year 1 Year 2 Year 3

Year 3 Year 2 Year 1 Year 3 Year 2
Year 1 Year 2 Year 3 Year 2 Year 3

BCK 7.87

Year 3 Year 2 Year 1 Year 3 Year 2

BCK 9.40

Year 3 Year 2 Year 1 Year 3 Year 2

BCK 9.91

$\frac{\text { Year } 3 \text { Year } 2}{\text { Year } 1}$ Year 3 Year 2

BCK 11.09

Year 2 Year 3 Year 1 Year 2 Year 3

BCK 11.83

Year 3 Year 2 Year 1 Year 3 Year 2

BCK 12.36

Year 3 Year 1 Year 2 Year 3 Year 2

Year 3 Year 2 Year 1 Year 3 Year 2

aYear 1 - June 1.984-May 1985, year 2 - October 1985-July 1986, and year 3 - October 1986-July 1987.

brhree-year comparisons are based on data from April, July and October except for BCK 11.09, which is based on data from Apri1 and October only. Comparisons between years 2 and 3 are based on all sampling dates except for BCK 11.09, which is based on data from January, April, and October only. 


\section{F -11}
Table F-7. Within-site comparisons of temporal changes in density of benthic macrolnvertebrates in Bear Creek reference streams, June 1984-July 1987. Years connected by the same line are not significantly different ( $p<0.05$ ) based on Tukey's studentized range (HSD) test. Years are arranged in order of highest to lowest values from left to right ${ }^{a, b}$

A11 taxa

Excluding decapoda and mollusca

BTK 0.3

Year 3 Year 2 Year 1

Year 3 Year 2

Year 3 Year 2 Year 1 Year 3 Year 2

Year 3 Year 2 Year 1 Year 3 Year 2

Year 3 Year 2 Year 1 Year 3 Year 2

Year 3 Year 2 Year 1 Year 3 Year 2

Year 3 Year 2 Year 1 Year 3 Year 2
Year 3 Year 2 Year 1

Year 3 Year 2

CCK 0.6

Year 3 Year 2 Year 1 Year 3 Year 2

GCK 2.4

Year 3 Year 2 Year 1 Year 3 Year 2

GHK 1.6

\author{
Year 3 Year 2 Year 1 \\ Year 3 Year 2
}

GHK 2.9

\author{
Year 3 Year 2 Year 1 \\ Yeax 3 Year 2
}

MBK 1.6 
Table F-7 (continued)

PHK 1.4

Year 3 Year 1 Year 2 Year 3 Year 2 $\frac{\text { Year } 3 \text { Year } 1 \text { Year } 2}{\text { Year } 3 \text { Year } 2}$

UTK 0.6

Year 3 Year 2 Year 1 Year 3 Year 2

\author{
Year 3 Year 2 Year 1 \\ Year 3 Year 2
}

WBK 1.0 $\frac{\text { Year } 3}{\text { Year } 3 \text { Year } 1 \text { Year } 2}$

Year 3 Year 1 Year 2 Year 3 Year 2

\footnotetext{
aYear 1 = June 1984-May 1985, year 2 = October 1985-July 1986, and year 3 = October 1986-July 1987.

bThree-year comparisons are based on data from October and April only. Comparisons between years 2 and 3 are based on all sampling periods.
} 


\section{F -13}

Table F-8. Within-site comparisons of temporal changes in biomass of benthic macroinvertebrates in Beax Creek reference streams, June 1984-July 1987. Years connected by the same line are not significantly different ( $p<0.05$ ) based on Tukey's studentized range (HSD) test. Years are arranged in order of highest to lowest values from left to right a,b

BTK 0.3

Year 1 Year 3 Year 2 Year 3 Year 2

Year 3 Year 2 Year 1 Year 2 Year 3

Year 2 Year 3 Year 1 Year 2 Year 3

Year 2 Year 3 Year 1 Year 2 Year 3

Year 2 Year 3 Year 1 Year 2 Year 3

Year 3 Year 2 Year 1 Year 3 Year 2

Year 2 Year 1 Year 3 Year 2 Year 3
Year 3 Year 2 Year 1 Year 2 Year 3

CCK 0.6

Year 3 Year 2 Year 1 Year 2 Year 3

GCK 2.4 $\frac{\text { Year } 3 \text { Year } 2 \text { Year } 1}{\text { Year } 2 \text { Year } 3}$

GHK 1.6

Year 1 Year 2 Year 3 Year 2 Year 3

GHK 2.9

Year 3 Year 1 Year 2 Year 3 Year 2

MBK 1.6

Year 3 Year 2 Year 1

Year 3 Year 2

PHK 1.4

Year 2 Year 1 Year 3 Year 2 Year 3 
Iable F-8 (continued)

UTK 0.6

Year 3 Year 2 Year 1 Year 3 Year 2

$$
\text { Year } 3 \text { Year } 1 \text { Year } 2
$$
Year 3 Year 2

WBK 1.0

\author{
Year 3 Year 1 Year 2 \\ Year 3 Year 2
}

\footnotetext{
aYear 1 = June 1984-May 1985, year 2 = October 1985-July 1986, and year 3 - October 1986-July 1987.

bThree-year comparisons are based on data from October and April only. Comparisons between years 2 and 3 are based on all sampling periods.
} 
Table F-9. Comparisons of mean benthic macroinvertebrate density (a11 taxa included) between Bear Creek and reference streams, October 1984 and April 1985. An ' $a$ ' or ' $b$ ' Indicates that the density at the Bear Creek site is significantly higher or lower $(\alpha=0.05)$, respectively, than the density at the reference site, and a blank indicates no statistical difference

\begin{tabular}{|c|c|c|c|c|c|c|c|c|c|}
\hline \multirow[b]{2}{*}{$\begin{array}{c}\text { Reference } \\
\text { site }\end{array}$} & \multicolumn{7}{|c|}{ Bear Creek site } & \multirow[b]{2}{*}{$\begin{array}{c}\text { BCK } \\
11.83\end{array}$} & \multirow[b]{2}{*}{$\begin{array}{c}\text { BCK } \\
12.36\end{array}$} \\
\hline & $\begin{array}{l}\text { BCK } \\
3.25\end{array}$ & $\begin{array}{l}\text { BCK } \\
5.15\end{array}$ & $\begin{array}{l}\text { BCK } \\
7.87\end{array}$ & $\begin{array}{l}\text { BCK } \\
9.40\end{array}$ & $\begin{array}{l}\text { BCK } \\
9.91\end{array}$ & $\begin{array}{c}\text { BCK } \\
10.32\end{array}$ & $\begin{array}{c}\text { BCK } \\
11.09\end{array}$ & & \\
\hline BFK 11.2 & & & & & $\mathrm{~b}$ & & $\mathrm{~b}$ & $\mathrm{~b}$ & $\mathrm{~b}$ \\
\hline BTK 0.3 & & & & & $b$ & & & $\mathrm{~b}$ & $b$ \\
\hline CCK 0.6 & & & & & $b$ & & & $\mathrm{~b}$ & $\mathrm{~b}$ \\
\hline GCK 1.4 & & & & & $b^{a}$ & $b^{c}$ & $b^{b}$ & $b^{a}$ & $b^{a}$ \\
\hline GCK 2.4 & $a^{a}$ & & & & $b^{a}$ & $b^{c}$ & $b^{b}$ & $b^{-}$ & $b^{a}$ \\
\hline GHK 1.6 & & & & & $b$ & & & $\mathrm{~b}$ & $\mathrm{~b}$ \\
\hline GHK 2.9 & & & & & $b$ & & & $\mathrm{~b}$ & $\mathrm{~b}$ \\
\hline HCK 25.4 & & & & & & & & & $\mathrm{~b}$ \\
\hline MBK 1.6 & & & & & $\mathrm{~b}$ & & & $\mathrm{~b}$ & $\mathrm{~b}$ \\
\hline PHK 1.4 & & & & & $\mathrm{~b}$ & $b$ & $b$ & $\mathrm{~b}$ & $\mathrm{~b}$ \\
\hline UTK 0.6 & & & & & $b$ & $\mathrm{~b}$ & $\mathrm{~b}$ & $\mathrm{~b}$ & $\mathrm{~b}$ \\
\hline WBK 1.0 & & & & & $\mathrm{~b}$ & & $\mathrm{~b}$ & $\mathrm{~b}$ & $\mathrm{~b}$ \\
\hline WCK 6.8 & & & & & b & & & b & b \\
\hline
\end{tabular}

"Comparison based on 10 sampling periods.

${ }^{b}$ Comparison based on nine sampling periods.

"Comparison based on seven sampling periods. 
Table F-10. Comparisons of mean benthic macroinvertebrate density, excluding Decapoda and Mollusca, between Bear Creek and reference streams, October 1984 and April 1985. An 'a' or 'b' indicates

that the density at the Bear Creek site is significantly

higher or lower $(\alpha=0.05)$, respectively, than the density at the reference site, and a blank

indicates no statistical difference

\begin{tabular}{|c|c|c|c|c|c|c|c|c|c|}
\hline \multirow[b]{2}{*}{$\begin{array}{l}\text { Reference } \\
\text { site }\end{array}$} & \multicolumn{7}{|c|}{ Bear Creek site } & \multirow[b]{2}{*}{$\begin{array}{c}\text { BCK } \\
11.83\end{array}$} & \multirow[b]{2}{*}{$\begin{array}{c}\text { BCK } \\
12.36\end{array}$} \\
\hline & $\begin{array}{l}\text { BCK } \\
3.25\end{array}$ & $\begin{array}{l}\text { BCK } \\
5.15\end{array}$ & $\begin{array}{l}\text { BCK } \\
7.87\end{array}$ & $\begin{array}{l}\text { BCK } \\
9.40\end{array}$ & $\begin{array}{l}\text { BCK } \\
9.91\end{array}$ & $\begin{array}{c}\text { BCK } \\
10.32\end{array}$ & $\begin{array}{c}\text { BCK } \\
11.09\end{array}$ & & \\
\hline BFK 11.2 & & & & & $\mathbf{b}$ & & & b & $b$ \\
\hline BTK 0.3 & & & & & $b$ & & & $\mathrm{~b}$ & b \\
\hline $\operatorname{CCK} \quad 0.3$ & & & & & $\mathrm{~b}$ & & & $\mathrm{~b}$ & $\mathrm{~b}$ \\
\hline GCK 1.4 & & & & & $b^{a}$ & $b^{c}$ & $b^{b}$ & $b^{a}$ & $b^{a}$ \\
\hline GCK 2.4 & & & & $a^{a}$ & $b^{a}$ & $b^{c}$ & $b^{b}$ & $b^{a}$ & $b^{a}$ \\
\hline GHK 1.6 & & & & & b & & & $\mathrm{b}$ & $\mathrm{b}$ \\
\hline GHK 2.y & & & & & $\mathrm{b}$ & & & $\mathrm{b}$ & $\mathrm{b}$ \\
\hline HCK 25.4 & & & & & & & & & $\mathrm{~b}$ \\
\hline MBK 1.6 & & & & & $\mathrm{~b}$ & & & & $\mathrm{~b}$ \\
\hline PHK 1.4 & & & & & b & b & $\mathrm{b}$ & $\mathrm{b}$ & $\mathrm{b}$ \\
\hline UTK 0.6 & & & & & b & $b$ & $b$ & $\mathrm{~b}$ & $\mathrm{~b}$ \\
\hline WBK 1.0 & & & & & $\mathrm{~b}$ & & & $\mathrm{~b}$ & $b$ \\
\hline WCK 6.8 & & & & & $\mathrm{~b}$ & & & b & $\mathrm{b}$ \\
\hline
\end{tabular}

"Comparison based on 10 sampling periods.

${ }^{b}$ Comparison based on nine sampling reriods.

"Comparison based on seven sampling periods. 
Table F-11. Comparisons of mean benthic macroinvertebrate density (a11 taxa (ncluded) between Bear Creek and reference streams, October 1985-July 1986. An ' $a$ ' or ' $b$ ' indicates that the density at the Bear Creek site is significantly higher or lower $(\alpha=0.05)$, respectively, than the density at the reference site, and a blank indicates no statistical difference

\begin{tabular}{|c|c|c|c|c|c|c|c|}
\hline \multirow[b]{2}{*}{$\begin{array}{l}\text { Reference } \\
\text { site }\end{array}$} & \multicolumn{5}{|c|}{ Bear Creek site } & \multirow[b]{2}{*}{$\begin{array}{c}\text { BCK } \\
11.83\end{array}$} & \multirow[b]{2}{*}{$\begin{array}{c}\text { BCK } \\
12.36\end{array}$} \\
\hline & $\begin{array}{l}\text { BCK } \\
3.25\end{array}$ & $\begin{array}{l}\text { BCK } \\
7.87\end{array}$ & $\begin{array}{l}\text { BCK } \\
9.40\end{array}$ & $\begin{array}{l}\text { BCK } \\
9.91\end{array}$ & $\begin{array}{c}\mathrm{BCK} \\
11.09^{\mathrm{a}}\end{array}$ & & \\
\hline BTK 0.3 & & & & & & $b$ & $\mathrm{~b}$ \\
\hline $\operatorname{CCK} 0.6$ & & & & & & $b$ & $\mathrm{~b}$ \\
\hline GCK 2.4 & a & & a & & & $\mathrm{b}$ & $\mathrm{b}$ \\
\hline GHK 1.6 & & & & & & $\mathrm{~b}$ & $\mathrm{~b}$ \\
\hline GHK 2.9 & $\mathbf{a}$ & & $a$ & & & $\mathrm{~b}$ & $\mathrm{~b}$ \\
\hline MBK 1.6 & & & & & & b & $b$ \\
\hline PHK 1.4 & & & & & & $\mathrm{~b}$ & $b$ \\
\hline UTK 0.6 & & $\mathrm{~b}$ & & $\mathrm{~b}$ & & $\mathrm{~b}$ & $\mathrm{~b}$ \\
\hline WBK 1.0 & & & & & & $b$ & $b$ \\
\hline
\end{tabular}

${ }^{a} B C K 11.09$ was dry in July 1986; therefore, comparison is based only on samples collected in October 1985, January 1986, and April 1986. 
Table F-12. Comparisons of mean benthic macrolnvertebrate density, excluding Decapoda and Mollusca, between Bear Creek and reference streams, October 1985-July 1986. An ' $a$ ' or ' $b$ ' indicates that the density at the Bear Creek site is significantly higher or lower $(\alpha=0.05)$, respectively, than the density at the reference site, and a blank indicates no statistical difference

\begin{tabular}{|c|c|c|c|c|c|c|c|}
\hline \multirow[b]{2}{*}{$\begin{array}{l}\text { Reference } \\
\text { site }\end{array}$} & \multicolumn{5}{|c|}{ Bear Creek site } & \multirow[b]{2}{*}{$\begin{array}{c}\text { BCK } \\
11.83\end{array}$} & \multirow[b]{2}{*}{$\begin{array}{c}\mathrm{BCK} \\
12.36\end{array}$} \\
\hline & $\begin{array}{l}\text { BCK } \\
3.25\end{array}$ & $\begin{array}{l}\mathrm{BCK} \\
7.87\end{array}$ & $\begin{array}{l}\mathrm{BCK} \\
9.40\end{array}$ & $\begin{array}{l}\text { BCK } \\
9.91\end{array}$ & $\begin{array}{c}\text { BCK } \\
11.09^{a}\end{array}$ & & \\
\hline BTK 0.3 & & & & & & $\mathrm{~b}$ & $\mathrm{~b}$ \\
\hline $\operatorname{CCK} 0.6$ & & & & & & $\mathrm{~b}$ & $\mathrm{~b}$ \\
\hline GCK 2.4 & a & & a & & a & & $\mathrm{b}$ \\
\hline GHK 1.6 & & & & & & $\mathrm{~b}$ & $\mathrm{~b}$ \\
\hline GHK 2.9 & a & & a & & & $b$ & $\mathrm{~b}$ \\
\hline MBK 1.6 & & & & & & $\mathrm{~b}$ & $\mathrm{~b}$ \\
\hline PHK 1.4 & & & & & & $\mathrm{~b}$ & $\mathrm{~b}$ \\
\hline UTK 0.6 & & $\mathrm{~b}$ & & $\mathrm{~b}$ & & $\mathrm{~b}$ & b \\
\hline WBK 1.0 & a & & a & & a & $\mathrm{b}$ & $\mathrm{b}$ \\
\hline
\end{tabular}


Table F-13. Comparisons of mean benthic macroinvertebrate density (al1 taxa Included) between Bear (reek and reference streams, October 1986-July 1987. An ' $a$ ' or ' $b$ ' Indicates that the density at the Bear Creek site is significantly higher or lower $(\alpha=0.05)$, respectively, than the density at the reference site, and a blank indicates no statistical difference

\begin{tabular}{|c|c|c|c|c|c|c|c|}
\hline \multirow[b]{2}{*}{$\begin{array}{l}\text { Reference } \\
\text { site }\end{array}$} & \multicolumn{5}{|c|}{ Bear Creek site } & \multirow[b]{2}{*}{$\begin{array}{c}\text { BCK } \\
11.83\end{array}$} & \multirow[b]{2}{*}{$\begin{array}{c}\text { BCK } \\
12.36\end{array}$} \\
\hline & $\begin{array}{l}\mathrm{BCK} \\
3.25\end{array}$ & $\begin{array}{l}\mathrm{BCK} \\
7.87\end{array}$ & $\begin{array}{l}\text { BCK } \\
9.40\end{array}$ & $\begin{array}{l}\text { BCK } \\
9.91\end{array}$ & $\begin{array}{c}\text { BCK } \\
11.09\end{array}$ & & \\
\hline BTK 0.3 & & & a & & $b$ & b & $\mathrm{b}$ \\
\hline CCK 0.6 & $\mathrm{~b}$ & & a & $\mathrm{b}$ & b & $\mathrm{b}$ & $\mathrm{b}$ \\
\hline GCK 2.4 & & & a & & & $\mathrm{b}$ & $\mathrm{b}$ \\
\hline GHK 1.6 & & & a & & b & $\mathrm{b}$ & $\mathrm{b}$ \\
\hline GHK 2.9 & $\mathrm{~b}$ & $\mathrm{~b}$ & & b & $\mathrm{b}$ & $\mathrm{b}$ & $\mathrm{b}$ \\
\hline $\mathrm{HCK} 20.6$ & & & a & & $\mathrm{b}$ & b & $\mathrm{b}$ \\
\hline MBK 1.6 & $\mathrm{~b}$ & $b$ & & $\mathrm{~b}$ & $\mathrm{~b}$ & b & $\mathrm{b}$ \\
\hline $\mathrm{PHK} 1.4$ & $\mathrm{~b}$ & b & & b & $\mathrm{b}$ & $\mathrm{b}$ & $b$ \\
\hline UTK 0.6 & $\mathrm{~b}$ & $\mathrm{~b}$ & & $\mathrm{~b}$ & $\mathrm{~b}$ & $\mathrm{~b}$ & $\mathrm{~b}$ \\
\hline WBK 1.0 & $\mathrm{~b}$ & & a & b & $\mathrm{b}$ & $\mathrm{b}$ & $\mathrm{b}$ \\
\hline
\end{tabular}


Table F-14. Comparisons of mean benthic macrolnvertebrate density, excluding Decapoda and Mollusca, between Bear Creek and reference streams, October 1986-July 1987. An ' $a$ ' or ' $b$ ' indicates that the density at the Bear Creek site is significantly higher or lower $(\alpha=0.05)$, respectively, than the density at the reference site, and a blank indicates no statistical difference

\begin{tabular}{|c|c|c|c|c|c|c|c|}
\hline \multirow[b]{2}{*}{$\begin{array}{l}\text { Reference } \\
\text { site }\end{array}$} & \multicolumn{5}{|c|}{ Bear Creek site } & \multirow[b]{2}{*}{$\begin{array}{c}\text { BCK } \\
11.83\end{array}$} & \multirow[b]{2}{*}{$\begin{array}{c}\text { BCK } \\
12.36\end{array}$} \\
\hline & $\begin{array}{l}\mathrm{BCK} \\
3.25\end{array}$ & $\begin{array}{l}\mathrm{BCK} \\
7.87\end{array}$ & $\begin{array}{l}\text { BCK } \\
9.40\end{array}$ & $\begin{array}{l}\text { BCK } \\
9.91\end{array}$ & $\begin{array}{c}\text { BCK } \\
11.09\end{array}$ & & \\
\hline BTK 0.3 & $\mathrm{~b}$ & & $\mathbf{a}$ & & $\mathrm{b}$ & $\mathrm{b}$ & $\mathrm{b}$ \\
\hline $\operatorname{CCK} \quad 0.6$ & b & & a & $\mathrm{b}$ & $\mathrm{b}$ & $b$ & $\mathrm{~b}$ \\
\hline GCK 2.4 & & & a & & & $\mathrm{b}$ & $\mathrm{b}$ \\
\hline GHK 1.6 & & & a & & & $\mathrm{b}$ & $b$ \\
\hline GHK 2.9 & $\mathrm{~b}$ & & & $\mathrm{~b}$ & $\mathrm{~b}$ & $\mathrm{~b}$ & $b$ \\
\hline HCK 20.6 & b & & a & & $\mathrm{b}$ & $b$ & $\mathrm{~b}$ \\
\hline MBK 1.6 & b & $\mathrm{b}$ & & b & $\mathrm{b}$ & b & $\mathrm{b}$ \\
\hline PHK 1.4 & $\mathrm{~b}$ & $\mathrm{~b}$ & & b & b & $\mathrm{b}$ & $\mathrm{b}$ \\
\hline UTK 0.6 & $b$ & $\mathrm{~b}$ & & $\mathrm{~b}$ & $\mathrm{~b}$ & $\mathrm{~b}$ & $\mathrm{~b}$ \\
\hline WBK 1.0 & $b$ & & a & $\mathrm{b}$ & $b$ & $\mathrm{~b}$ & $b$ \\
\hline
\end{tabular}


Table F-15. Comparisons of mean benthic macroinvertebrate bionass (al1 taxa included) between Bear Creek and reference streams, October 1984 and April 1985. An ' $a$ ' or ' $b$ ' Indicates that the biomass at the Bear Creek site is significantly higher or lower $(\alpha=0.05)$, respectively, thati the biomass at the reference site, and a blank indicates no statistical difference

\section{Bear Creek site}

$\begin{array}{cllllllllc}\text { Reference } & \text { BCK } & \text { BCK } & \text { BCK } & \text { BCK } & \text { BCK } & \text { BCK } & \text { BCK } & \text { BCK } & \text { BCK } \\ \text { site } & 3.25 & 5.15 & 7.87 & 9.40 & 9.91 & 10.32 & 11.09 & 11.83 & 12.36\end{array}$

BFK 11.2

$\mathrm{b}$

b b

b

b $\quad b$

BTK 0.3

b

b $\quad$ b

CCK 0.6

$\begin{array}{lllll}b & b & b & b & b\end{array}$

GCK 1.4

$b^{a}$

$b^{a} \quad b^{c}$

$b^{b}$

$b^{a} \quad b^{a}$

GCK 2.4

$b^{a} \quad b$

$b^{\mathbf{a}}$

$b^{a} \quad b^{c}$

$b^{b}$

$b^{a} \quad b^{a}$

GHK 1.6

b

b b

b

b $\quad$ b

GHK 2.9

a

HCK 25.4

MBK 1.6

b b

b

b

PHK 1.4

b b

b

(a)

UTK 0.6

b b

b

b

b

b

WBK 1.0

b b

b

b b

WCK 6.8

b b

b

b $\quad b$

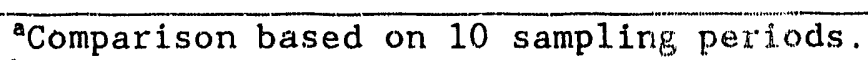

${ }^{b}$ Comparison based on nine sampling periods.

${ }^{c}$ Comparison based on seven sampling periods. 
Table F-16. Comparisons of mean benthic macrolnvertebrate biomass, excluding Decapoda and Mollusca, between Bear Creek and reference streams, October 1984 and April 1985. An 'a' or 'b' indicates that the blomass at the Bear Creek site is significantly higher or lower $(\alpha=0.05)$, respectively, than the biomass at the reference site, and a blank indicates no statistical difference

\begin{tabular}{|c|c|c|c|c|c|c|c|c|c|}
\hline \multirow[b]{2}{*}{$\begin{array}{l}\text { Reference } \\
\text { site }\end{array}$} & \multicolumn{7}{|c|}{ Bear Creek site } & \multirow[b]{2}{*}{$\begin{array}{c}\text { BCK } \\
11.83\end{array}$} & \multirow[b]{2}{*}{$\begin{array}{c}\text { BCK } \\
12.36\end{array}$} \\
\hline & $\begin{array}{l}\text { BCK } \\
3.25\end{array}$ & $\begin{array}{l}\mathrm{BCK} \\
5.15\end{array}$ & $\begin{array}{l}\text { BCK } \\
7.87\end{array}$ & $\begin{array}{l}\text { BCK } \\
9.40\end{array}$ & $\begin{array}{l}\mathrm{BCK} \\
9.91\end{array}$ & $\begin{array}{c}\text { BCK } \\
10.32\end{array}$ & $\begin{array}{c}\mathrm{BCK} \\
11.09\end{array}$ & & \\
\hline BFK 11.2 & & & & & $\mathbf{b}$ & $\mathbf{b}$ & $\mathrm{b}$ & b & $\mathrm{b}$ \\
\hline BTK 0.3 & & & & & $\mathrm{~b}$ & & $\mathrm{~b}$ & $\mathrm{~b}$ & b \\
\hline $\operatorname{CCK} 0.6$ & & & & & b & & & $\mathrm{b}$ & $\mathrm{b}$ \\
\hline GCK 1.4 & & & $b^{a}$ & & $b^{a}$ & $b^{c}$ & $b^{b}$ & $b^{a}$ & $b^{a}$ \\
\hline $\operatorname{GCK} 2.4$ & & & $b^{a}$ & & $b^{a}$ & $b^{c}$ & $b^{b}$ & $b^{a}$ & $b^{a}$ \\
\hline GHK 1.6 & & & & & $\mathrm{~b}$ & $\mathrm{~b}$ & $\mathbf{b}$ & $b$ & $\mathrm{~b}$ \\
\hline GHK 2.9 & & & & & b & b & $\mathrm{b}$ & $\mathrm{b}$ & $\mathrm{b}$ \\
\hline HCK 25.4 & a & & & $\mathbf{a}$ & & & & $\mathrm{b}$ & $\mathrm{b}$ \\
\hline $\mathrm{MBK} 1.6$ & & & & & & & & $\mathrm{~b}$ & $\mathrm{~b}$ \\
\hline PHK 1.4 & & & & & $\mathrm{~b}$ & $\mathrm{~b}$ & $\mathbf{b}$ & $\mathrm{b}$ & $\mathrm{b}$ \\
\hline UTK 0.6 & & & & & $\mathrm{~b}$ & $\mathbf{b}$ & $\mathrm{b}$ & $\mathrm{b}$ & $\mathrm{b}$ \\
\hline WBK 1.0 & & & & & $\mathrm{~b}$ & $\mathrm{~b}$ & $\mathrm{~b}$ & $\mathrm{~b}$ & $\mathrm{~b}$ \\
\hline WCK 6.8 & & & & & $\mathrm{~b}$ & & & $\mathrm{~b}$ & $b$ \\
\hline
\end{tabular}

${ }^{-}$Comparison based on 10 sampling periods.

${ }^{b}$ Comparison based on nine sampling pexiods.

${ }^{\circ}$ Comparison based on seven sampling periods . 
Table F-17. Comparisons of mean benthic macrolnvertebrate biomass (a11 caxa included) between Bear Creek and reference streams, October 1985-July 1986. An ' $a$ ' or ' $b$ ' indicates that the biomass at the Bear Creek site is significantly higher or lower $(\alpha=0.05)$, respectively, than the biomass at the reference site, and a blank indicates no statistical difference

\begin{tabular}{|c|c|c|c|c|c|c|c|}
\hline \multirow[b]{2}{*}{$\begin{array}{l}\text { Reference } \\
\text { site }\end{array}$} & \multirow[b]{2}{*}{$\begin{array}{l}\text { BCK } \\
3.2 !\end{array}$} & \multicolumn{3}{|c|}{ Bear Creek site } & \multirow[b]{2}{*}{$\begin{array}{c}\text { BCK } \\
11.09^{a}\end{array}$} & \multirow[b]{2}{*}{$\begin{array}{c}\text { BCK } \\
11.83\end{array}$} & \multirow[b]{2}{*}{$\begin{array}{c}\text { BCK } \\
12.36\end{array}$} \\
\hline & & $\begin{array}{l}\text { BCK } \\
7.87\end{array}$ & $\begin{array}{l}\text { BCK } \\
9.40\end{array}$ & $\begin{array}{l}\text { BCK } \\
9.91\end{array}$ & & & \\
\hline BTK 0.3 & $\mathbf{a}$ & & & & & $\mathrm{b}$ & $\mathrm{b}$ \\
\hline $\operatorname{CCK} 0.6$ & & $\mathrm{~b}$ & & $\mathrm{~b}$ & $\mathrm{~b}$ & b & $\mathrm{b}$ \\
\hline GCK 2.4 & & $\mathrm{~b}$ & $\mathrm{~b}$ & $b$ & $\mathrm{~b}$ & $\mathrm{~b}$ & $\mathrm{~b}$ \\
\hline GHK 1.6 & & $\mathrm{~b}$ & $\mathrm{~b}$ & $\mathrm{~b}$ & $\mathrm{~b}$ & $\mathrm{~b}$ & $\mathrm{~b}$ \\
\hline GHK 2.9 & & $\mathrm{~b}$ & $\mathrm{~b}$ & $b$ & $\mathrm{~b}$ & $\mathrm{~b}$ & $\mathrm{~b}$ \\
\hline MBK 1.6 & & $\mathrm{~b}$ & $\mathrm{~b}$ & $\mathrm{~b}$ & $\mathrm{~b}$ & $b$ & $\mathrm{~b}$ \\
\hline PHK 1.4 & & $b$ & & $\mathrm{~b}$ & & $\mathrm{~b}$ & $\mathrm{~b}$ \\
\hline UTK 0.6 & & $\mathrm{~b}$ & & $\mathrm{~b}$ & & b & b \\
\hline WBK 1.0 & & $\mathbf{b}$ & $b$ & $\mathrm{~b}$ & $\mathrm{~b}$ & $\mathrm{~b}$ & $\mathrm{~b}$ \\
\hline
\end{tabular}


Table F-18. Comparisons of mean benthic macrolnvertebrate biomass excluding Decapoda and Mollusca, between Bear Creek and reference streams, October 1985-July 1986. An ' $a$ ' or ' $b$ ' Indicates that the blomass at the Bear Creek site is significantly higher or

lower $(\alpha-0.05)$, respectively, than the biomass at the reference site, and a blank indicates no statistical difference

\begin{tabular}{|c|c|c|c|c|c|c|c|}
\hline \multirow[b]{2}{*}{$\begin{array}{c}\text { Reference } \\
\text { site }\end{array}$} & \multicolumn{5}{|c|}{ Bear Creek site } & \multirow[b]{2}{*}{$\begin{array}{c}\text { BCK } \\
11.83\end{array}$} & \multirow[b]{2}{*}{$\begin{array}{c}\text { BCK } \\
12.36\end{array}$} \\
\hline & $\begin{array}{l}\text { BCK } \\
3.25\end{array}$ & $\begin{array}{l}\text { BCK } \\
7.87\end{array}$ & $\begin{array}{l}\text { BCK } \\
9.40\end{array}$ & $\begin{array}{l}\text { BCK } \\
9.91\end{array}$ & $\begin{array}{c}\text { BCK } \\
11.09^{\mathrm{a}}\end{array}$ & & \\
\hline BTK 0.3 & $a$ & & & & & b & $\mathrm{b}$ \\
\hline $\operatorname{CCK} 0.6$ & $a$ & & a & & & $b$ & $b$ \\
\hline GCK 2.4 & a & & a & & & $b$ & $b$ \\
\hline GHK 1.6 & & & & $\mathrm{~b}$ & & $b$ & $\mathrm{~b}$ \\
\hline GHK 2.9 & & & & $\mathrm{~b}$ & & $b$ & $b$ \\
\hline MBK 1.6 & & & & $b$ & & $b$ & $\mathrm{~b}$ \\
\hline PHK 1.4 & & b & & b & b & b & $\mathrm{b}$ \\
\hline UTK 0.6 & & $\mathrm{~b}$ & & $\mathrm{~b}$ & $\mathbf{b}$ & b & $\mathrm{b}$ \\
\hline WBK 1.0 & & & & $\mathrm{~b}$ & & b & b \\
\hline
\end{tabular}


Table F-19. Comparisons of mean benthic macroinvertebrate biomass (a11 taxa included) between Bear Creek and refexence streams,

October 1986-July 1987. An 'a' or ' $b$ ' Indicates that the biomass at the Bear Creek site is significantly higher or lower $(\alpha=0.05)$, respectivel.y, than the blomass at the reference site, and a blank indicates no statistical difference

\begin{tabular}{|c|c|c|c|c|c|c|c|}
\hline \multirow[b]{2}{*}{$\begin{array}{c}\text { Reference } \\
\text { site }\end{array}$} & \multicolumn{5}{|c|}{ Bear Creek site } & \multirow[b]{2}{*}{$\begin{array}{c}\mathrm{BCK} \\
11.83\end{array}$} & \multirow[b]{2}{*}{$\begin{array}{c}\text { BCK } \\
12.36\end{array}$} \\
\hline & $\begin{array}{l}\text { BCK } \\
3.25\end{array}$ & $\begin{array}{l}\text { BCK } \\
7.87\end{array}$ & $\begin{array}{l}\text { BCK } \\
9.40\end{array}$ & $\begin{array}{l}\text { BCK } \\
9.91\end{array}$ & $\begin{array}{c}\text { BCK } \\
11.09\end{array}$ & & \\
\hline BTK 0.3 & a & & a & & & & $\mathrm{b}$ \\
\hline CCK 0.6 & & $b$ & & $\mathrm{~b}$ & $\mathrm{~b}$ & $b$ & $\mathrm{~b}$ \\
\hline GCK 2.4 & & $\mathrm{~b}$ & b & $\mathrm{b}$ & $\mathrm{b}$ & $\mathrm{b}$ & $\mathrm{b}$ \\
\hline GHK 1.6 & & $\mathrm{~b}$ & & b & $\mathrm{b}$ & $b$ & $\mathrm{~b}$ \\
\hline GHK 2.9 & & $\mathbf{b}$ & & $\mathbf{b}$ & b & b & $\mathrm{b}$ \\
\hline HCK 20.6 & & $\mathrm{~b}$ & $b$ & b & $\mathrm{b}$ & $\mathrm{b}$ & $\mathrm{b}$ \\
\hline MBK 1.6 & & $\mathrm{~b}$ & $b$ & b & $\mathrm{b}$ & $b$ & $\mathrm{~b}$ \\
\hline PHK 1.4 & a & & & b & $\mathrm{b}$ & $\mathrm{b}$ & b \\
\hline UTK 0.6 & & $\mathrm{~b}$ & & $\mathrm{~b}$ & $\mathrm{~b}$ & $\mathrm{~b}$ & $\mathrm{~b}$ \\
\hline WBK 1.0 & & $\mathrm{~b}$ & & b & $b$ & $b$ & $\mathrm{~b}$ \\
\hline
\end{tabular}


Table F-20. Comparisons of mean benthic macroinvertebrate biomass, excluding Decapoda and Mollusca, between Bear Creek and reference streams, October 1.986-July 1987. An ' $a$ ' or ' $b$ ' indicates that the biomass at the Bear Creek site is significantly higher or lower $(\alpha=0.05)$, respectively, than the biomass at the reference site, and a blank indicates no statistical difference.

\begin{tabular}{|c|c|c|c|c|c|c|c|}
\hline \multirow[b]{2}{*}{$\begin{array}{l}\text { Reference } \\
\text { site }\end{array}$} & \multicolumn{5}{|c|}{ Bear Creek site } & \multirow[b]{2}{*}{$\begin{array}{c}\text { BCK } \\
11.83\end{array}$} & \multirow[b]{2}{*}{$\begin{array}{c}\text { BCK } \\
12.36\end{array}$} \\
\hline & $\begin{array}{l}\text { BCK } \\
3.25\end{array}$ & $\begin{array}{l}\text { BCK } \\
7.87\end{array}$ & $\begin{array}{l}\text { BCK } \\
9.40\end{array}$ & $\begin{array}{l}\text { BCK } \\
9.91\end{array}$ & $\begin{array}{c}\text { BCK } \\
11.09\end{array}$ & & \\
\hline BTK 0.3 & & & $\mathbf{a}$ & & & $\mathrm{b}$ & $\mathrm{b}$ \\
\hline $\operatorname{CCK} 0.6$ & & & $\mathbf{a}$ & & & $\mathrm{b}$ & $b$ \\
\hline GCK 2.4 & & & $a$ & & $\mathrm{~b}$ & $\mathrm{~b}$ & $\mathrm{~b}$ \\
\hline GHK 1.6 & & & a & & $\mathrm{b}$ & $\mathrm{b}$ & $\mathrm{b}$ \\
\hline GHK 2.9 & & & & b & $\mathrm{b}$ & $\mathrm{b}$ & $\mathrm{b}$ \\
\hline HCK 20.6 & & & $\mathbf{a}$ & & & & $b$ \\
\hline $\operatorname{MBK} 1.6$ & $b$ & b & & $\mathrm{b}$ & $\mathrm{b}$ & $\mathrm{b}$ & $\mathrm{b}$ \\
\hline PHK 1.4 & & & & $\mathrm{~b}$ & $\mathrm{~b}$ & b & $\mathrm{b}$ \\
\hline UTK 0.6 & $\mathrm{~b}$ & $b$ & & $\mathrm{~b}$ & $\mathrm{~b}$ & $\mathrm{~b}$ & $\mathrm{~b}$ \\
\hline WBK 1.0 & & & & b & b & b & b \\
\hline
\end{tabular}




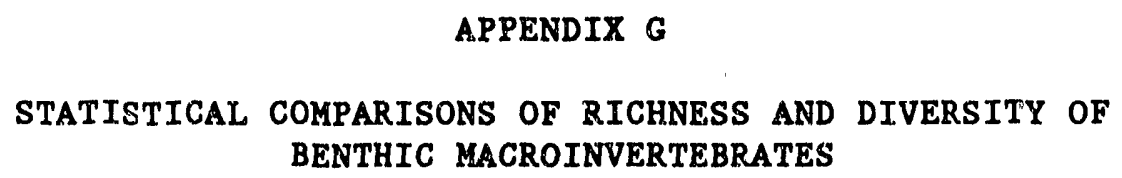


Table G-1. Within-site comparisons of temporal changes in richness and diversity of benthic macroinvertebrates in Bear Creek, June 1984-July 1987. Years connected by the same line are not significantly different ( $p<0.05$ ) based on Tukey's studentized range (HSD) test. Years are arranged in order of highest to lowest values from left to right ${ }^{a, b}$

BCK 3.25

Year 3 Year 2 Year 1 Year 3 Year 2

Year 3 Year 2 Year 1 Year 3 Year 2

Year 3 Year 2 Year 1 Year 3 Year 2

Year 2 Year 3 Year 1 Year 3 Year 2

Year 2 Year 1 Year 3 Year 2 Year 3

Year 3 Year 2 Year 1 Year 3 Year 2
Year 2 Year 3 Year 1 Year 2 Year 3

BCK 7.87

Year 3 Year 2 Year 1 Year 3 Year 2

BCK 9.40

Year 3 Year 2 Year 1 Year 3 Year 2

BCK 9.91

Year 3 Year 2 Year 1 Year 3 Year 2

BCK 11.09

Year 2 Year 3 Year 1 Year 2 Year 3

BCK 11.83 $\frac{\text { Year } 3}{\text { Year } 3 \text { Year } 2}$ Year 2

BCK 12.36
Year 3 Year 1 Year 2

Year 3 Year 2 
Table G-2. Within-site comparison of temporal changes in richness and diversity of benthic macroinvertebrates in Bear Creek reference streams, June 1984-July 1987. Years connected by the same line are not significantly different $(p<0.05)$ based on Tukey's studentized range (HSD) test. Years are axranged in order by highest to lowest values from left to righta,b

\begin{tabular}{ll}
\hline Diversity & Richness \\
\hline
\end{tabular}

BTK 0.3

Year 3 Year 2 Year 1 Year 3 Year 2

Year 2 Year 3 Year 1 Year 3 Year 2

Year 3 Year 2 Year 1 Year 3 Year 2

Year 2 Year 3 Year 1 Year 3 Year 2
Year 3 Year 2 Year 1 Year 3 Year 2

CCK 0.6

Year 3 Year 2 Year 1 Year 3 Year 2

GCK 2.4

Year 3 Year 2 Year 1 Year 3 Year 2

GHK 1.6

Year 3 Year 2 Year 1 Year 3 Year 2

GHK 2.9

Year 3 Year 2 Year 1

Year 3 Year 2

Year 3 Year 2 Year 1

Year 3 Year 2

MBK 1.6

Year 3 Year 2 Year 1 Year 3 Year 2

Year 3 Year 2 Year 1 Year 3 Year 2

PHK 1.4

Year 2 Year 1 Year 3

Year 3 Year 2 Year 1

Year 2 Year 3
Year 3 Year 2 
G. 5

Table G-2 (continued)

Diversity Richness

PHK 1.4

Year 2 Year 1 Year 3

Yegr 2 year 3
Year 3 Year 2 Year 1

Year 3 Year 2

UTK 0.6

Year 2 Year 3 Year 1

Year 2 Year 3

WBK 1.0

Year 3 Year 1 Year 2

Year 3 Year 1 Year 2

Year 3 Year 2

Year 3 Year 2

ayear 1 wune 1984-May 1985, year 2 - October 1985-July 1986, and year 3 - October 1986-.July 1987.

bThree-year comparisons are based on April and October sampling periods only. Comparisons between years 2 and 3 are based on all sampling periods. 
Table G-3. Comparisons of benthic macrolnvertebrate richness in Bear Creek, June 1984-July 1987. Sites connected by the saine line are not significantly different $(p<0.05)$ based on Tukey's studentized range (HSD) test. Sites are arranged in order of highest to lowest values from left to right. Except where noted, differences are based on 10 sampling periods in year 1 and

4 sampling perlods in years 2 and 3

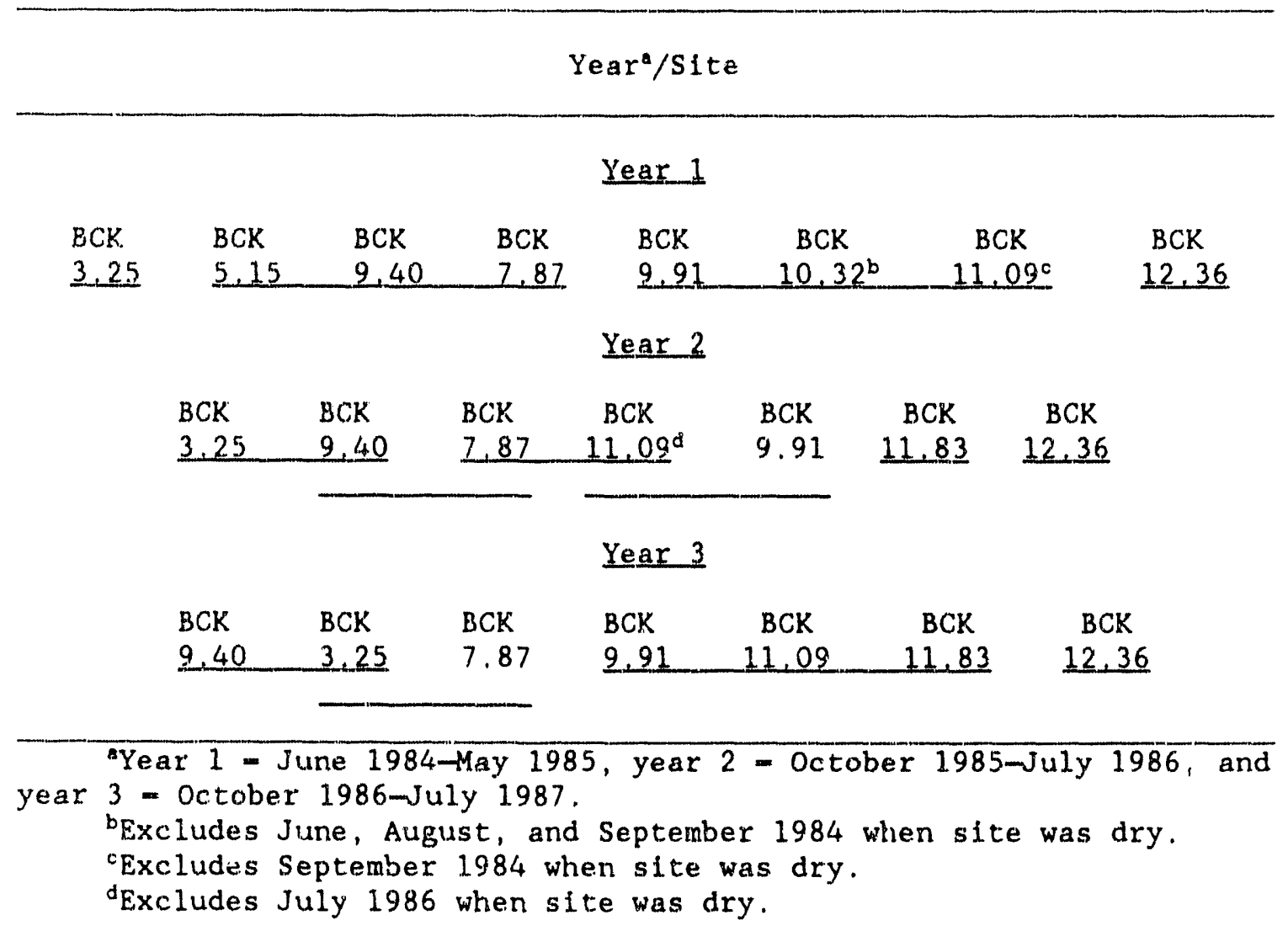


Table G-4. Comparisons of benthic macroinvertebrate richness in Bear Creek reference streams, June 1984 July 1987 . Sites connected by

the same line are not significantly different $(p<0.05)$ based

on Tukey's studentized range (HSD) test. Sltes are arranged in order of highest to lowest values from left to right. Differences are based on two sampling periods in year 1 and four sampling perlods in years 2 and 3

\section{Year $/$ Site}

\begin{tabular}{|c|c|c|c|c|c|c|c|c|c|c|c|}
\hline \multicolumn{12}{|c|}{ Year 1} \\
\hline $\begin{array}{l}\text { UTK } \\
0.6\end{array}$ & $\begin{array}{l}\text { BFK } \\
11,2 \\
\end{array}$ & $\begin{array}{l}\text { PHK } \\
1,4\end{array}$ & $\begin{array}{l}\text { BTK } \\
0.3 \\
\end{array}$ & $\begin{array}{l}\text { WCK } \\
6.8 \\
\end{array}$ & $\begin{array}{l}\text { WBK } \\
1.0 \\
\end{array}$ & $\begin{array}{l}\text { GHK } \\
1.6 \\
\end{array}$ & $\begin{array}{c}\text { GHK } \\
2.9 \\
\end{array}$ & $\begin{array}{l}\mathrm{MBK} \\
1.6 \\
\end{array}$ & $\begin{array}{c}\mathrm{GCK} \\
1.4 \\
\end{array}$ & $\begin{array}{cc}\mathrm{CCK} & \mathrm{GGK} \\
0.6 & 2.4 \\
\end{array}$ & $\begin{array}{r}\mathrm{HCK} \\
25.4\end{array}$ \\
\hline
\end{tabular}

\begin{tabular}{lllllllll}
\multicolumn{8}{c}{ Year 2 } \\
UTK & BTK & MBK & CCK & PHK & GHK & GHK & WBK & GCK \\
0.6 & 0.3 & 1.6 & 0.6 & 1.4 & 1.6 & 2.9 & 1.0 & 2.4 \\
\hline
\end{tabular}

Year 3

UTK MBK PHK BTK WBK GHK CCK HCK GCK GHK

O.C. $\begin{array}{lllllllll}1.6 & 1.4 & 0.3 & 1.0 & 2.9 & 0.6 & 20.6 & 2.4 & 1.6\end{array}$

Year 1 = June 1984-May 1985, year 2 - October 1985-July 1986, and year $3=$ October 1986-July 1987 . 
Table G-5. Comparisons of benthic macrolnvertebrate richness between Bear Creek and reference streams, June 1984-May 1985. An 'a' or ' $b$ ' indicates that the richness at the Bear Creek site is signficantly higher or lower $(\alpha=0.05)$, respectively, than the rlchness at

the reference site, and a blank indicates no statistical difference. Unless otherwise noted compartsons are based on samples collected in October 1984 and Apr11 1985

\begin{tabular}{|c|c|c|c|c|c|c|c|c|c|}
\hline \multirow[b]{2}{*}{$\begin{array}{c}\text { Reference } \\
\text { site }\end{array}$} & \multirow[b]{2}{*}{$\begin{array}{l}\mathrm{BCK} \\
3.25\end{array}$} & \multirow[b]{2}{*}{$\begin{array}{l}\mathrm{BCK} \\
5.15\end{array}$} & \multicolumn{3}{|c|}{ Bear Creek site } & \multirow[b]{2}{*}{$\begin{array}{c}\text { BCK } \\
10.32\end{array}$} & \multirow[b]{2}{*}{$\begin{array}{c}\mathrm{BCK} \\
11.09\end{array}$} & \multirow[b]{2}{*}{$\begin{array}{c}\text { BCK } \\
11.83\end{array}$} & \multirow[b]{2}{*}{$\begin{array}{c}\text { BCK } \\
12.36\end{array}$} \\
\hline & & & $\begin{array}{l}\mathrm{BCK} \\
7.87\end{array}$ & $\begin{array}{l}\mathrm{BCK} \\
9.40\end{array}$ & $\begin{array}{l}\text { BCK } \\
9.91\end{array}$ & & & & \\
\hline BFK 11.2 & & & & $\mathrm{~b}$ & $\mathrm{~b}$ & $b$ & $b$ & $\mathrm{~b}$ & \\
\hline BTK 0.3 & & & & $\mathrm{~b}$ & $b$ & $\mathrm{~b}$ & $b$ & b & \\
\hline $\operatorname{CCK} 0.6$ & & & & & $b$ & & & b & $b$ \\
\hline GCK 1.4 & & $b^{a}$ & $b^{a}$ & $b^{a}$ & $b^{a}$ & $b^{c}$ & $b^{b}$ & $b^{a}$ & $b^{a}$ \\
\hline GCK 2.4 & & & $b^{a}$ & $b^{*}$ & $b^{a}$ & $b^{c}$ & $b^{b}$ & $b^{*}$ & $b^{a}$ \\
\hline GHK 1.6 & & & & & $b$ & b & $\mathrm{b}$ & $b$ & $b$ \\
\hline GHK 2.9 & & & & & $b$ & & b & $b$ & $b$ \\
\hline HCK 25.4 & & & & & & & & $b$ & $\mathrm{~b}$ \\
\hline $\mathrm{MBK} 1.6$ & & & & & b & & $b$ & $b$ & \\
\hline PHK 1.4 & & & & & b & $\mathrm{b}$ & $\mathrm{b}$ & $b$ & $b$ \\
\hline UTK 0.6 & & $\mathrm{~b}$ & $b$ & & b & $b$ & $b$ & $b$ & $\mathrm{~b}$ \\
\hline WBK 1.0 & & & & & $b$ & $\mathrm{~b}$ & $b$ & $b$ & $b$ \\
\hline WCK 6.8 & & & & & b & $\mathrm{b}$ & $b$ & $b$ & $\mathrm{~b}$ \\
\hline
\end{tabular}

- Comparison based on 10 sampling periods.

bomparison based on nine sampling periods.

'Comparison based on seven sampling periods. 
Table G-6. Comparisons of benthic macrolnvertebrate richness between

Bear Creek and reference streams, October 1985-July 1986. An 'a' or ' $b$ ' Indicates that richness at the Bear Creek site is significantiy higher or lower $(\alpha=0.05)$, respectively, than that of the reference site, and a blank indicates no statistical difference

\begin{tabular}{|c|c|c|c|c|c|c|c|}
\hline \multirow[b]{2}{*}{$\begin{array}{l}\text { Reference } \\
\text { site }\end{array}$} & \multicolumn{6}{|c|}{ Bear Creek site } & \multirow[b]{2}{*}{$\begin{array}{c}\text { BCK } \\
12.36\end{array}$} \\
\hline & $\begin{array}{l}\text { BCK } \\
3.25\end{array}$ & $\begin{array}{l}\text { BCK } \\
7.87\end{array}$ & $\begin{array}{l}\text { BCK } \\
9.40\end{array}$ & $\begin{array}{l}\text { BCK } \\
9.91\end{array}$ & $\begin{array}{c}\text { BCK } \\
11.09^{a}\end{array}$ & $\begin{array}{c}\text { BCK } \\
11.83\end{array}$ & \\
\hline BTK 0.3 & & & $\mathrm{~b}$ & b & $b$ & b & $b$ \\
\hline $\mathrm{CCK} 0.6$ & & & & $b$ & $\mathrm{~b}$ & $b$ & $b$ \\
\hline GCK 2.4 & & & & & $\mathrm{~b}$ & b & $b$ \\
\hline GHK 1.6 & & & & $b$ & $b$ & $\mathrm{~b}$ & $\mathrm{~b}$ \\
\hline GHK 2.9 & & & & $\mathrm{~b}$ & $b$ & $\mathrm{~b}$ & $\mathrm{~b}$ \\
\hline MBK 1.6 & & & & $\mathrm{~b}$ & $\mathrm{~b}$ & b & $b$ \\
\hline PHK 1.4 & & & & b & $b$ & $\mathrm{~b}$ & $\mathrm{~b}$ \\
\hline UTK 0.6 & & & $\mathrm{~b}$ & $\mathrm{~b}$ & $b$ & $\mathrm{~b}$ & $b$ \\
\hline WBK 1.0 & & & & & b & b & $\mathrm{b}$ \\
\hline
\end{tabular}

${ }^{\mathrm{B} B C K} 11.09$ was dry in July 1986; therefore, the comparison is based only on samples collected in October 1985, January 1986, and April 1986. 
Table G-7. Comparisons of benthic macrolnvertebrate richness between

Bear Creek and reference streams, October 1986-July 1987. An 'a'

or ' $b$ ' Indicates that richness at the Bear Creek sites is

significantly higher or lower $(\alpha-0.05)$, respectively, than that of the reference site, and a blank

indicates no statistical difference

\begin{tabular}{|c|c|c|c|c|c|c|c|}
\hline \multirow[b]{2}{*}{$\begin{array}{c}\text { Reference } \\
\text { site }\end{array}$} & \multicolumn{6}{|c|}{ Bear Creek site } & \multirow[b]{2}{*}{$\begin{array}{r}B C K \\
12.36\end{array}$} \\
\hline & $\begin{array}{l}\text { BCK } \\
3.25\end{array}$ & $\begin{array}{l}\mathrm{BCK} \\
7.87\end{array}$ & $\begin{array}{l}\text { BCK } \\
9.40\end{array}$ & $\begin{array}{l}\text { BCK } \\
9.91\end{array}$ & $\begin{array}{c}\mathrm{BCK} \\
11.09\end{array}$ & $\begin{array}{r}\text { BCK } \\
11.83\end{array}$ & \\
\hline BTK 0.3 & $b$ & $b$ & & $b$ & $\mathrm{~b}$ & $\mathrm{~b}$ & $b$ \\
\hline $\operatorname{CCK} 0.6$ & $\mathrm{~b}$ & $b$ & & $\mathrm{~b}$ & b & $b$ & $\mathrm{~b}$ \\
\hline GCK 2.4 & $\mathrm{~b}$ & $\mathrm{~b}$ & & $\mathrm{~b}$ & $\mathrm{~b}$ & $\mathrm{~b}$ & $\mathrm{~b}$ \\
\hline GHK 1.6 & $\mathrm{~b}$ & b & & $\mathrm{b}$ & $\mathrm{b}$ & $b$ & $b$ \\
\hline GHK 2.9 & $\mathrm{~b}$ & b & & b & $\mathrm{b}$ & $\mathrm{b}$ & $\mathrm{b}$ \\
\hline HCK 20.6 & $b$ & $b$ & & $\mathrm{~b}$ & $b$ & $\mathrm{~b}$ & $\mathrm{~b}$ \\
\hline MBK 1.6 & $b$ & $\mathrm{~b}$ & $b$ & $b$ & $b$ & $b$ & $\mathrm{~b}$ \\
\hline PHK 1.4 & $\mathrm{~b}$ & $b$ & & $\mathrm{~b}$ & $b$ & b & $b$ \\
\hline UTK 0.6 & $\mathrm{~b}$ & $\mathrm{~b}$ & $b$ & $b$ & $b$ & $\mathrm{~b}$ & $\mathrm{~b}$ \\
\hline WBK 1.0 & $\mathrm{~b}$ & $b$ & & $b$ & $b$ & $b$ & $\mathrm{~b}$ \\
\hline
\end{tabular}




\section{G-11}

Table G-8. Comparisons of benthic macroinvertebrate diversity in Bear Creek, June 1984-July 1987. Sites connected by the same line are not significantly different $(\alpha=0.05)$ based on Tukey's studentized range (HSD) test. Sites are arranged in order of highest to lowest values from left to right. Except where noted, differences are based on two sampling periods in year

1 and four sampling perlods in years 2 and 3

Year $^{a} /$ Site

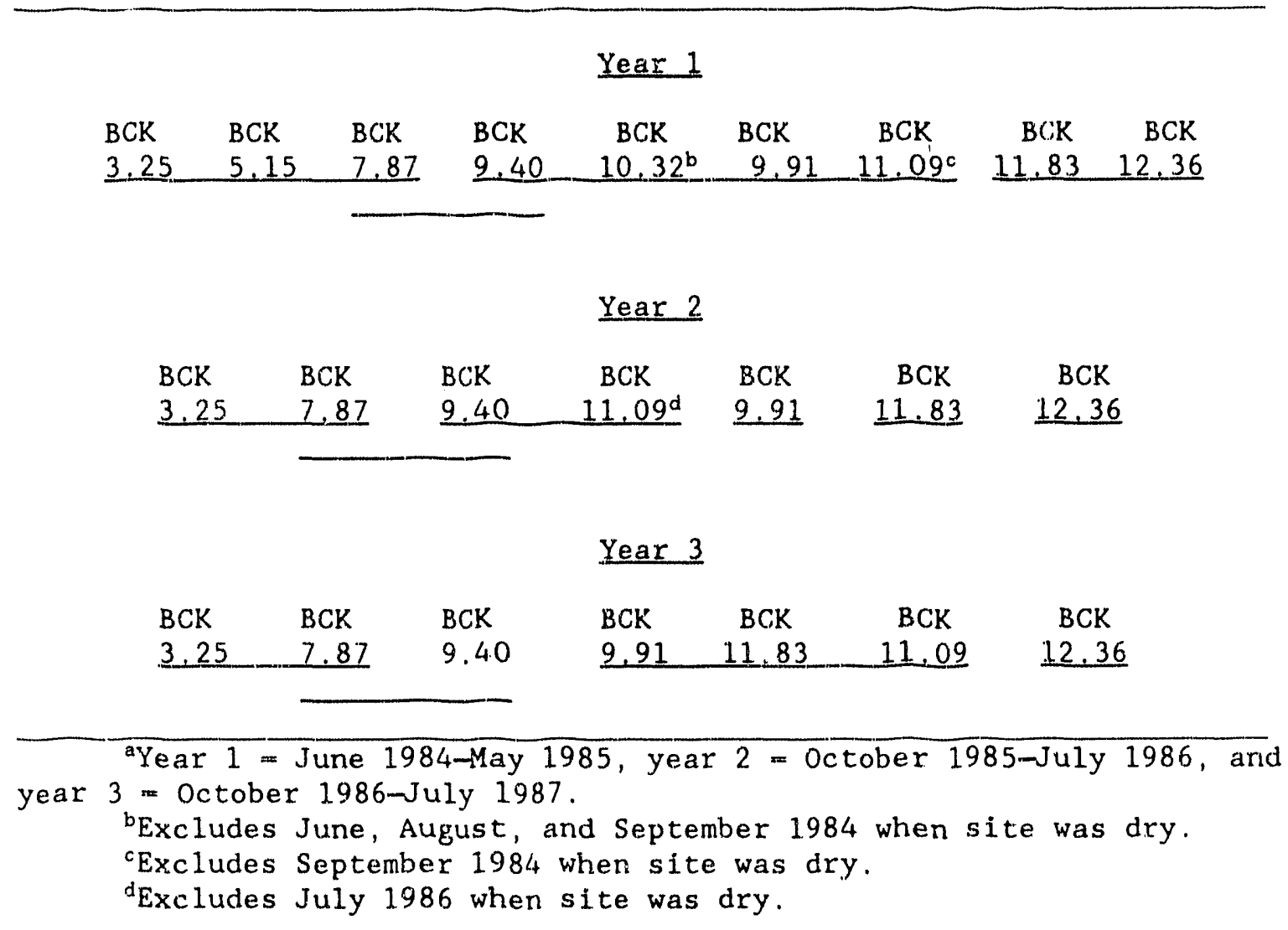


Table G-9. Comparisons of benthic macrolnvertebrate diversity in Bear Creek reference streams, June 1984-July 1987. Sites connected by the same line are not significantly different $(p<0.05)$ based on Tukey's studentized range (HSD) test. Sites are arranged in order of highest to lowest values from left to right.

Differences are based on two sampling periods in year 1 and four sampling perlods in years 2 and 3

\section{Year $/$ Site}

\section{Year 1}

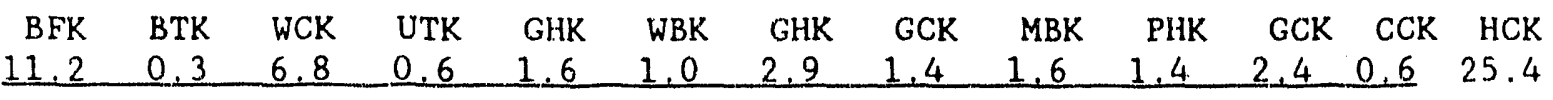

Year 2

\begin{tabular}{lllllllll} 
UTK & BTK & GHK & PHK & MBK & GHK & CCK & GCK & WBK \\
0.6 & 0.3 & 1.6 & 1.4 & 1.6 & 2.9 & 0.6 & 2.4 & 1.0 \\
\hline
\end{tabular}

Year 3

\begin{tabular}{llllllrlll} 
UTK & BTK & MBK & WBK & GHK & GCK & HCK & GHK & CCK & PHK \\
0.6 & 0.3 & 1.6 & 1.0 & 1.6 & 2.4 & 20.6 & 2.9 & 0.6 & 1.4 \\
\hline
\end{tabular}

ayear $1=$ June 1984-May 1985, year $2=$ October 1985-July 1986, and year 3 = October 1986-July 1987. 
Table G-10. Comparisons of benthlc macroinvertebrate diversity between Bear Creek and reference streams, June 1984-May 1985. An 'a' or 'b' indicates that diversity at the Bear Creek site is significantly higher or lower $(\alpha=0.05)$, respectively, than that of the reference site, and a blank indicates no statistical difference. Unless otherwise noted, comparisons are based on samples collected in October 1984 and April 1985 only

\begin{tabular}{|c|c|c|c|c|c|c|c|c|c|}
\hline \multirow[b]{2}{*}{$\begin{array}{l}\text { Reference } \\
\text { site } \\
\quad 12.36\end{array}$} & \multirow[b]{2}{*}{$\begin{array}{l}\text { BCK } \\
3.25\end{array}$} & \multirow[b]{2}{*}{$\mathrm{BCK}$} & \multicolumn{3}{|c|}{ Bear Creek site } & \multirow[b]{2}{*}{$\begin{array}{l}\text { BCK } \\
9.91\end{array}$} & \multirow[b]{2}{*}{$\begin{array}{l}\text { BCK } \\
10.32\end{array}$} & \multirow[b]{2}{*}{$\begin{array}{l}\text { BCK } \\
11.09\end{array}$} & \multirow[b]{2}{*}{$\begin{array}{c}\text { BCK } \\
11.83\end{array}$} \\
\hline & & & $\begin{array}{l}\text { BCK } \\
5.15\end{array}$ & $\begin{array}{l}\text { BCK } \\
7.87\end{array}$ & $\begin{array}{l}\text { BCK } \\
9.40\end{array}$ & & & & \\
\hline BFK 112 & & & & & $\mathrm{~b}$ & & $\mathrm{~b}$ & $\mathrm{~b}$ & $\mathrm{~b}$ \\
\hline BTK 0.3 & & & & & $\mathrm{~b}$ & & $b$ & $\mathrm{~b}$ & $\mathrm{~b}$ \\
\hline CCK 0.6 & & & & & & & & $\mathrm{~b}$ & $b$ \\
\hline GCK 1.4 & & & $b^{a}$ & $b^{a}$ & $b^{a}$ & $b^{c}$ & $\mathrm{~b}^{\mathrm{b}}$ & $b^{a}$ & $b^{a}$ \\
\hline GCK 2.4 & & & & $b^{a}$ & $b^{a}$ & $b^{c}$ & $b^{b}$ & $b^{a}$ & $b^{a}$ \\
\hline GHK 1.6 & & & & & $b$ & & & $\mathrm{~b}$ & $\mathrm{~b}$ \\
\hline GHK 2.9 & & & & & $\mathrm{~b}$ & & & $\mathrm{~b}$ & b \\
\hline HCK 25.4 & & & & & & & & $\mathrm{~b}$ & $\mathrm{~b}$ \\
\hline MBK 1.6 & & & & & & & & $\mathrm{~b}$ & $\mathrm{~b}$ \\
\hline PHK 1.4 & & & & & & & & $\mathrm{~b}$ & $\mathrm{~b}$ \\
\hline UTK 0.6 & & & & & $\mathrm{~b}$ & & & $\mathrm{~b}$ & $\mathrm{~b}$ \\
\hline WBK 1.0 & & & & & b & & & $\mathrm{b}$ & $\mathrm{b}$ \\
\hline WCK 6.8 & & & & & b & & & $\mathrm{b}$ & $\mathrm{b}$ \\
\hline
\end{tabular}

${ }^{a}$ Comparison based on 10 sampling periods.

${ }^{b}$ Comparison based on nine sampling periods.

Comparison based on seven sampling periods. 
Table G-11. Comparisons of benthic macrolnvertebrate diversity between Bear Creek and reference streams, October 1985-July 1986. An 'a' or ' $b$ ' Indicates that diversity at the Bear Creek site is significantly higher or lower $(\alpha=0.05)$, respectively, than that of the reference site, and a blank indicates no statistical difference

\begin{tabular}{|c|c|c|c|c|c|c|c|}
\hline \multirow[b]{2}{*}{$\begin{array}{l}\text { Reference } \\
\text { site }\end{array}$} & \multicolumn{6}{|c|}{ Bear Creek site } & \multirow[b]{2}{*}{$\begin{array}{c}\text { BCK } \\
12.36\end{array}$} \\
\hline & $\begin{array}{l}\text { BCK } \\
3.25\end{array}$ & $\begin{array}{l}\text { BCK } \\
7.87\end{array}$ & $\begin{array}{l}\text { BCK } \\
9.40\end{array}$ & $\begin{array}{l}\text { BCK } \\
9.91\end{array}$ & $\begin{array}{c}\text { BCK } \\
11.09^{\mathrm{a}}\end{array}$ & $\begin{array}{c}\text { BCK } \\
11.83\end{array}$ & \\
\hline BTK 0.3 & & $\mathrm{~b}$ & $b$ & $\mathbf{b}$ & $b$ & $b$ & $\mathrm{~b}$ \\
\hline $\operatorname{CCK} 0.6$ & & & b & $b$ & $\mathrm{~b}$ & $\mathrm{~b}$ & $\mathrm{~b}$ \\
\hline GCK 2.4 & & & & $b$ & $\mathrm{~b}$ & $\mathrm{~b}$ & $\mathrm{~b}$ \\
\hline GHK 1.6 & & & $\mathrm{~b}$ & $\mathrm{~b}$ & $\mathrm{~b}$ & $\mathrm{~b}$ & b \\
\hline GHK 2.9 & & & $b$ & $\mathrm{~b}$ & $b$ & $\mathrm{~b}$ & $b$ \\
\hline MBK 1.6 & & & $\mathrm{~b}$ & b & $\mathrm{b}$ & $\mathrm{b}$ & b \\
\hline PHK 1.4 & & & b & $b$ & $\mathbf{b}$ & $\mathrm{b}$ & b \\
\hline UTK 0.6 & & b & $b$ & b & b & $\mathbf{b}$ & $\mathbf{b}$ \\
\hline WBK 1.0 & & & & $b$ & & b & b \\
\hline
\end{tabular}


Table G-12. Comparisons of benthic macroinvertebrate diversity between Bear Creek and reference streams, October 1986-July 1987. An 'a' or ' $b$ ' indicates that diversity at the Bear Creek site is significantly higher or lower $(\alpha=0.05)$, respectively, than that of the reference site, and a blank indicates no statistical difference

\begin{tabular}{|c|c|c|c|c|c|c|c|}
\hline \multirow[b]{2}{*}{$\begin{array}{c}\text { Reference } \\
\text { site }\end{array}$} & \multirow[b]{2}{*}{$\begin{array}{l}\text { BCK } \\
3.25\end{array}$} & \multicolumn{4}{|c|}{ Bear Creek site } & \multirow[b]{2}{*}{$\begin{array}{r}\text { BCK } \\
11.83\end{array}$} & \multirow[b]{2}{*}{$\begin{array}{r}\text { BCK } \\
12.36\end{array}$} \\
\hline & & $\begin{array}{l}\mathrm{BCK} \\
7.87\end{array}$ & $\begin{array}{l}\text { BCK } \\
9.40\end{array}$ & $\begin{array}{l}\text { BCK } \\
9.91\end{array}$ & $\begin{array}{c}\text { BCK } \\
11.09\end{array}$ & & \\
\hline BTK 0.3 & & $\mathrm{~b}$ & b & $\mathrm{b}$ & $b$ & b & $\mathrm{b}$ \\
\hline CCK 0.6 & & & $\mathrm{~b}$ & $\mathrm{~b}$ & $\mathrm{~b}$ & $\mathrm{~b}$ & $b$ \\
\hline GCK 2.4 & & $\mathrm{~b}$ & $b$ & b & $\mathrm{b}$ & $b$ & $b$ \\
\hline GHK 1.6 & & b & $\mathrm{b}$ & $b$ & $b$ & $b$ & $b$ \\
\hline GHK 2.9 & & & $\mathrm{~b}$ & $\mathrm{~b}$ & $\mathrm{~b}$ & $\mathrm{~b}$ & $b$ \\
\hline HCK 20.6 & & & b & $b$ & $b$ & $\mathrm{~b}$ & $\mathrm{~b}$ \\
\hline MBK 1.6 & & $\mathrm{~b}$ & $\mathrm{~b}$ & $b$ & $b$ & $\mathrm{~b}$ & $\mathrm{~b}$ \\
\hline PHK 1.4 & & & $b$ & 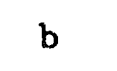 & $\mathrm{b}$ & $b$ & $b$ \\
\hline UTK 0.6 & & $\mathrm{~b}$ & $\mathrm{~b}$ & $\mathrm{~b}$ & $b$ & b & $\mathrm{b}$ \\
\hline WBK 1.0 & & $\mathrm{~b}$ & $\mathrm{~b}$ & $b$ & $\mathrm{~b}$ & $b$ & $\mathrm{~b}$ \\
\hline
\end{tabular}


ORNL/TM - 11977

INTERNAL DISTRIBUTION

1. S. M. Adams

2. L. J. Allison

3. T. L. Ashwood

4. B. G. Blaylock

5. H. L. Boston

6. H. M. Braunstein

7. G, F, Cada

8. S. W. Christensen

9. B. F. Clark

10. R. B. Clapp

11. E. T. Collins

12. C. C. Coutant

13. M. F. P. Delozier

14. H. L. Fellers

15. M. L. Frank

16. C. W. Gehrs

17. S. G. Hildebrand

18. C. C. Hill

19. R. L. Hinzman

20. M. A. Huston

21. B. L. Kimme 1

22. J. M. Loar

23. R. B. McLean

24. L. W. McMahon

25. L. A. Muhs

26. M. J. Peterson
27.

28.

29.

30.

31.

32 .

33-44.

45 .

46.

47.

48 .

49.

50 .

51.

52.

53.

54.

55.

56.

57.

$58-72$.

$73-76$.

$77-78$.

79.

80.

81 .
M. G. Ryon

E. H. Schilling

J. A. Shaakir-A1i

B. A. Shoemaker.

L. R. Shugart

J. G. Smith

G. R. Southworth

A. J. Stewart

J. E. Stone

G. W. Suter

D. W. Swindle

T. S. Tison

J. R. Trabalka

R. R. Turner

W. Van Winkle

L. O. Vaughan

S. Walker

M. C. Wiest

$R$. K. White

Central Research Library

ESD Library

ER Document Manage. Ctr

Laboratory Records Dept

Laboratory Records-RC

ORNL Patent office

ORNL Y-12 Technical Lib

\section{EXTERNAL DISTRIBUTION}

82. S. Ahlstedt, Division of Water Resources, Tennessee Valley Authority, Norr:is, TN 37828

83. J. A. Burris, C.E. Environmental, Inc., 2571 Executive Center, Tallahassee, FL 32301

84. D. S. Day, Environmental Division, U.S. Department of Energy, Savannah River Operations Office, Box A, Aiken, SC 29802

85. P. H. Edmonds, Radian Corporoation, 120 South Jefferson Circle, Oak Ridge, TN 37830

86. W. Fisher, Department of Zoology, Oklahoma State University, Stillwater, OK 74078

87. J. F. Franklin, Bloedel Professor of Ecosystem Analysis, College of Forest Resources, University of Washington, Anderson Hall (AR-10), Seattle, WA 98195

88. C. S. Gist, Environmental Protection Division, SE-31, DOE Oak Ridge Field office, P.O. Box 2001, Oak Ridge, TN 37830

89. H. W. Hibbitts, Deputy Assistant Manager, Department of Environment, Safety and Quality, SE-30, DOE Oak Ridge Field Office, P.O. Box 2001, Oak Ridge, TN 37830 
90. D. R. Hopkins, U.S. Environmental Protection Agency, 345 Courtland Street, N.E., Atlanta, GA 30365

91. G. M. Hornberger, Professor, Department of Environmental Sciences, Universlty of Virginla, Charlottesville, VA 22903

92. G. Y. Jordy, Director, Office of Frogram Analysis, Office of Energy Research, ER-30, G.226, U.S. Department of Energy, Washington, DC 20545

93. T. Joseph, Environmental Remediation Branch, Environmental Protection Division, SE-312, DOE Oak RIdge Field Dffice, P.O. 2001, Oak Ridge, TN 37830

94. R. A. Jump, Environmental Restoration Division, EW-91, DOE Oak Ridge Field office, P.O. Box 2001, Oak Ridge, iN 37830

95. J, T. Kitchings, Stanford Place 3, Sulte 415, $4582 \mathrm{~S}$. U1ster Street Parkway, Denver, Co 80237

96. W. A. Kncher, 1219 Riverband Drive, Kingston, TN 37763

97. E. C. Leming, Director, DOE Oversight Division, 761 Enory Valley Road, Oak Ricge, TN 37830-7072

98. G. J. Marciante, Environmental Protection Division, SE 31 , DOE Oak Ridge Field office, P.O. Box 200!, Oak Ridge, Oak Ridge, TN 37830

99. A. D. McKinney, Chief, Environmencal Services, TWRA, P.0. Box 40747, Ellington Agricultural Certer, Nashvilie, TN 37204

100. C. R. Olsen, Envirormental Sciences Division, Office of Health and Environmental Research, ER-74, U.S. Department of Energy, Washington, DC 20585

101. R, H. Olsen, V1i' President for Research, Universtty of Michigan, Medical Science Building II, \#5605, 1301 East Catherine Street, Ann Arbor, MI 48109-0620

102. A. Patrinos, Acting Director, Environmental sciences Division, Office of Health and Environmental Research, ER-74, U.S. Depat inent of Energy, Washington, DC 20585

103. S, S. Perkins, DOE Oak Ridge Field offi-e, Information Resource Center, 105 Broadway, Oak Ridge, TN 37830

104, S. P. Riddle, Environmental Restoration Division, EW-91, DOE Oak Ridge Fleld Offlce, P.O. Box 2001, Oak Ridge, TN 37830

105. W. Schacher, Aquatic Habitat Protection Biologist, Tennessee Wildife Resources Agency, $6032 \mathrm{~W}$. Andrew Johnson Highway, Talbet, TN 37877

106. R. C. Sleeman, Environmental Restoration Division, EW-91, DOE Oak Ridge Field office, P.O. Box 2001, Oak Rldge, TN 37830

107. D. Turner, 1201 Tuskegee Drive, Oak Ridge, TN 37830

108. C. R, Wenze1, SAIC, Box 2501, Oak Ridge, TN 37831-2501

109. F. J. Wobber, Enviromental Sciences Division, Office of Health and Environmental Research, ER. 74, U,S. Department of Energy, Washingtor, DC 20585

110. Office of Assistant Manager for Energy Research and Development, DOE Oak Ridge Field Offlce, Oak Ridge, P.O. box 2001, Oak Ridge, TN 37831.8600

111-119. Office of Sclentific and Technical Information, P,0. Box 62, Oak Ridge, TN 37331 

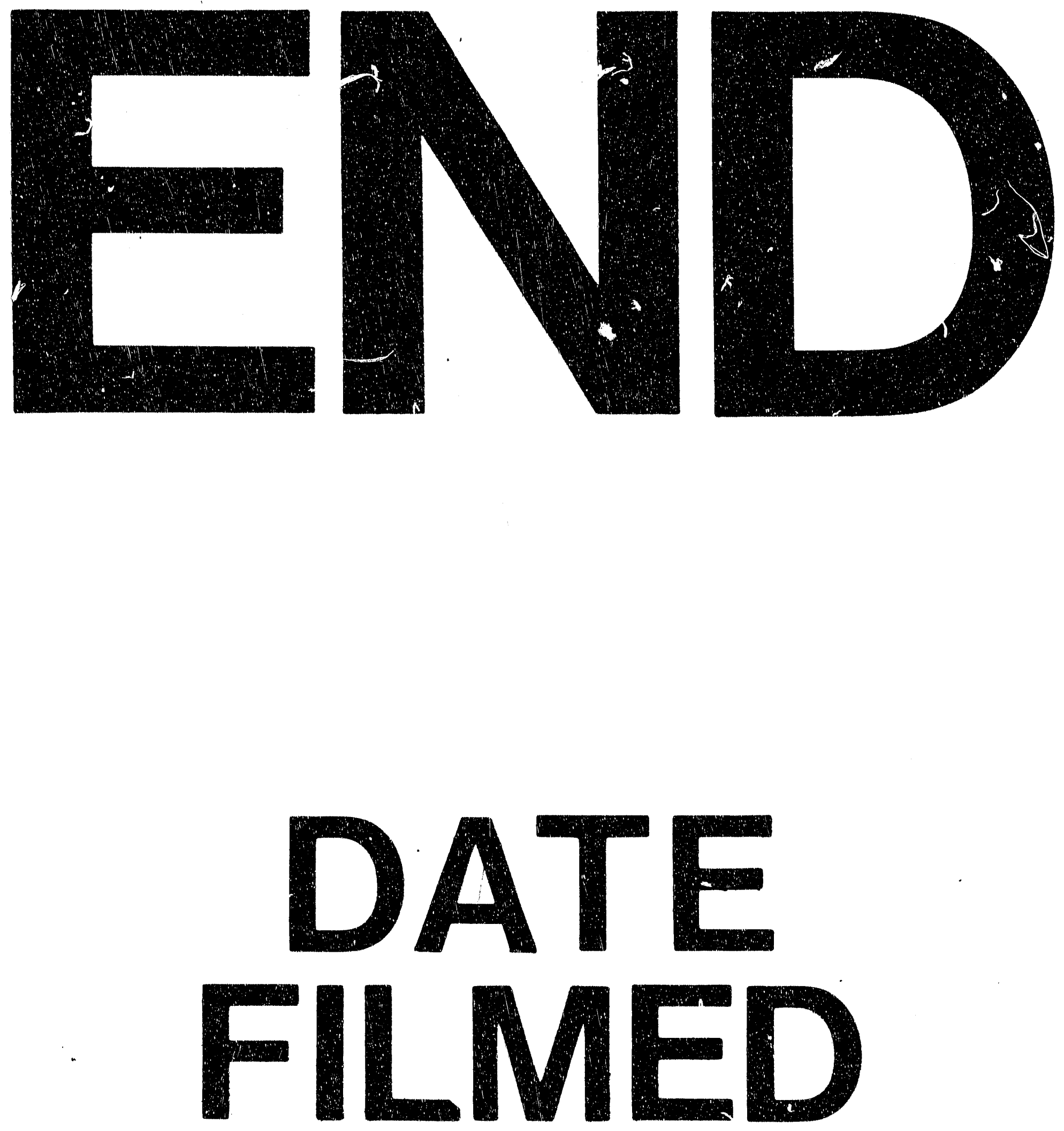

$\mathbf{I}$

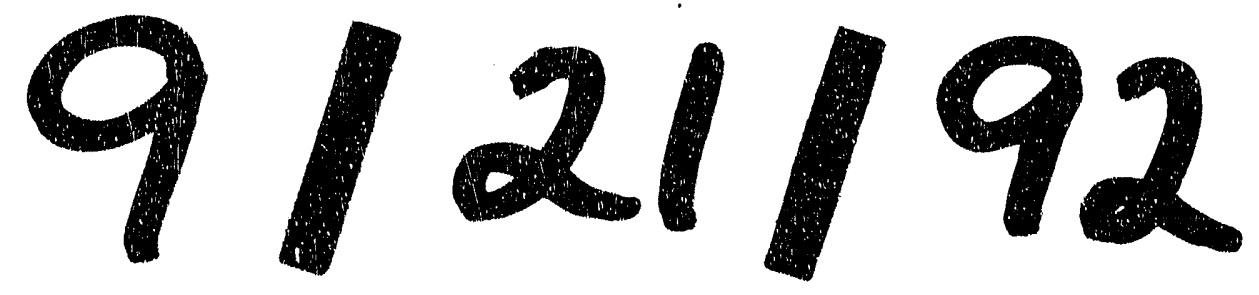


